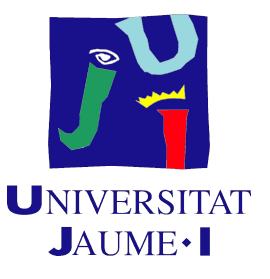

\title{
Enhancing Pest Management in Sweet Pepper by the Exploitation of Zoophytophagy
}

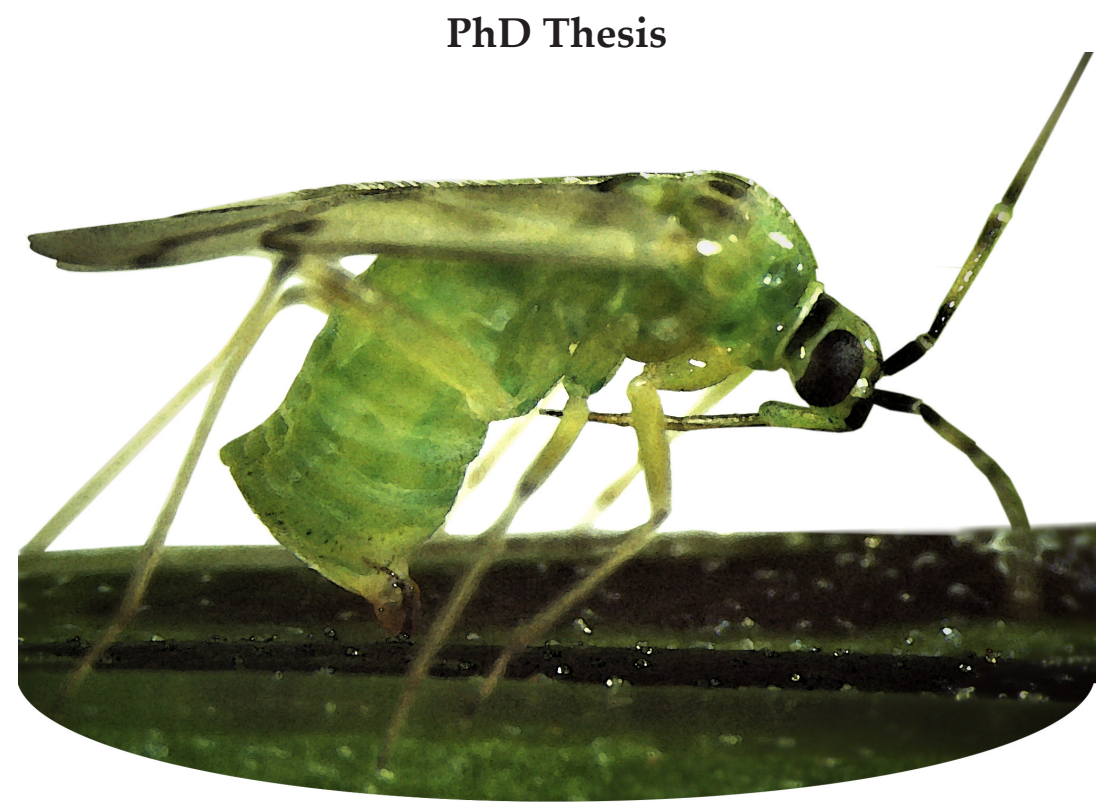

SARRA BOUAGGA 




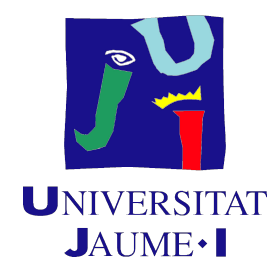

Doctoral Program in Sciences

Doctorate School of Jaume I University

\section{Enhancing Pest Management in Sweet Pepper by the Exploitation of Zoophytophagy}

PhD Thesis Presented by SARRA BOUAGGA to obtain the degree of Doctoral of Phylosophy

Jaume I University

Sarra Bouagga Supervisors

Dr. Alberto Urbaneja

Dr. Meritxell Pérez-Hedo 



\section{Aknowledgments}

Writing the acknowledgement brings to me the past four years of $\mathrm{PhD}$ and all its corresponding memories. Crossing the Mediterranean Sea from Tunisia, I came to the IVIA in January 2014, to start this PhD adventure. Studying for being a Doctor of Philosophy was intensive, I have cried too much when experiments went to the wrong direction, but also I enjoyed seeing my publications online. I am proud to finish it with this thesis book in my hand based on four-years of work, I also feel a sense of being lost now this special period of my life is coming to an end. Doing a PhD is more like a unique experience of "knowing yourself" rather than performing research, and it has helped me to find out what is my field of interest and a direction for a future career. Of course, I did not do this all on my own, I have always considered myself so lucky to get help from people during every stage of my life.

First of all, I like to express my special gratitude to my supervisors, Dr. Alberto Urbaneja \& Dr. Meritxell Pérez-Hedo, I could not finished my PhD without your help, support, guidance and encouragement, You were always available for contributing even in the small details of my thesis. Alberto, thank you for offering me the chance to join the department of plant protection and biotechnology and to work within the Entomology team. Thank you both for the time dedicated for my work, no matter how busy you are, I received your revisions on my manuscripts early in the morning, during weekends and when you were abroad...Thanks for the effort that you made to finally reach this end.

I also need to give a big grateful thanks to Russell IPM ltd UK, which financially supported my stay in Valencia to conduct my PhD. Since 2011, I know Dr. Nayem Hassan, the head of research \& development and Dr. Shakir Al-Zaidi, the head manager director of the company, always you 
were in my side, always you were pushing me toward science, always you have believed in my capacities, far away from business, you were the most generous people that I have ever met.

I greatly appreciate the support received through the collaborative work undertaken with Dr. Antonio Granell and Dr. José Luis Rambla from The Institute for Plant Molecular and Cellular Biology "IBMCP" and Dr. Victor Flors from the department of Agricultural and Environmental Sciences, Jaume I university, Many thanks for your assistance with the volatiles and phytohormones quantifications.

My sincerest thanks are also extended to my academic tutor, Dr. Josep Antonio Jaques and to all the administrative staff of the doctoral school within Jaume I university.

Deepest thanks to Dr. Judit Arnó and Dr. Francisco Javier Calvo for their careful and constructive review of the thesis, the comments, corrections, and suggestions that you have ensued were certainly helpful.

How nice that I shared these four years of my life within the Entofamily, Special thanks to Dr. Francisco José Beitia, Dr. Alejandro Tena, Dr. César Monzó, Dr. Elena Llácer and Dr. Óscar Dembilio for sharing knowledge, advice and continuous encouragement. Big thanks for the technical and for the affection support of peoples with whom I shared my daily work in IVIA, I need to start with Miquel Alonso, without your technical help big part from the thesis could not be possible. Thanks a lot to Virginia Pedroche, Maria José Camaró and to the Greece Erasmus students (Zoe and Dimitris) for their help within the greenhouse and behaviour experiments. Very special thanks goes to Alice Mockford, I appreciate your advices and the time that you have dedicated for the constructive review of my first two articles.

The most enjoyable part of this $\mathrm{PhD}$ has been meeting wonderful colleagues from all over the world; some special words of gratitude go to all my friends who have always been a major source of support when things would get a bit discouraging. Thanks guys: for always being there for me, I am lucky for sharing many tears and much more laughter with all of you. "Abir, Alice, Angeliki, Azu, Francesc, Jessi, José, Juan Pedro, Marta, Miguel, Milena, Omar, Puri, Rihem and the sweetheart Ruth" 
Undoubtedly, to you "Karelia", really I cannot find words to express my recognitions, if the world have more people like you it would be a better place.

My exceptional and grateful thanks are also accorded to my beloved and wonderful parents "Mourad \& Nadia", my sister "Asma" and my brothers "Moenes \& Ramzi", who have always stood by me like a pillar in times of need and to whom I owe my life for their constant love, encouragement, moral support and blessings. Your patience and sacrifice will remain as my inspiration throughout my life.

And finally, I owe my deepest gratitude towards my better half, my dearest husband and my best friend "Houssem", for the eternal support and understanding of my goals and aspirations, your infallible love and support has always been my strength. Without your help, I would not have been able to complete much of what I have done and become who I am.

The last word goes for "Aylen", my baby boy, who has been the light of my life for the last two years and who has given me the extra strength and motivation to get things done.

Many many thanks to all of you, my dear family, supervisors, friends and colleagues, for being part of my life!

Moncada, 14/02/2018 



\section{Summary}

During the last decade, integrated pest management programs based on the augmentation and conservation of zoophytophagous predators have been successfully developed in horticulture greenhouses. In sweet pepper, the release of Amblyseius swirskii Athias-Henriot (Acari: Phytoseiidae) and Orius laevigatus Fieber (Hemiptera: Anthocoridae) has provided effective control of two key pests, the Western flower thrips Frankliniella occidentalis Pergande (Thysanoptera: Tripidae) and the whitefly Bemisia tabaci Gennadius (Hemiptera: Aleyrodidae). Despite being a zoophytophagous predator, the phytophagous behaviour of O. laevigatus has not been previously explored in depth, nor has the impact of phytophagy on plant physiology. In the first objective of this $\mathrm{PhD}$, the hierarchical significance of $O$. laevigatus feeding on sweet pepper was compared with other behaviours. Orius laevigatus spent the majority of its time (38\%) feeding on apical meristems and apical fresh leaves, which were also preferred residence locations. The phytophagous feeding behaviour of $O$. laevigatus on sweet pepper was shown to trigger defensive responses in the plant. These O. laevigatus plant induced defences were then shown to contribute to the repellence or attraction of pests or natural enemies, respectively. Specifically, O. laevigatus-punctured sweet pepper plants induced repellency for the whitefly $B$. tabaci and the thrips F. occidentalis. In contrast, the whitefly parasitoid Encarsia formosa Gahan (Hymenoptera: Aphelinidae) was significantly attracted to O. laevigatuspunctured plants. The plant responses to O. laevigatus punctures included 
the release of an altered blend of volatiles and activation of the jasmonate acid and salicylic acid signalling pathways. These results highlight an interesting facet to the biology of O. laevigatus, in which the ability of the predator to induce defensive responses in sweet pepper plants may serve to improve the biological control (BC) of both thrips and whiteflies. Indeed, the results could explain the great success achieved by IPM programs based on the release, establishment and conservation of O. laevigatus in sweet pepper crops.

Nevertheless, sweet pepper pest management is still fronting problems because of aphids in the crop. To maintain aphids' population below an economic thresholds, multiples release of specialized natural enemies are needed. This strategy results in a complicated food web due to the large number of species released that which ends up making the release program too expensive for producers. In recent years, looking for alternative aphid's natural enemies which could be integrated with the current and systematically-implemented BC practices in sweet pepper has been one of the research priorities. In this line, the role of predatory mirids (Hemiptera: Miridae) in managing aphids in sweet pepper has been highlighted in several studies. In addition to their services as predators, mirid predators are able to induce plant defences by phytophagy. However, whether this induction occurs in sweet pepper and whether it could be an additional benefit to their role as BC agent in this crop remains unknown. These questions were addressed in the second objective of this $\mathrm{PhD}$, and were investigated in two model insects, the mirids Nesidiocoris tenuis Reuter and Macrolophus pygmaeus Rambur. Plant feeding behaviour was observed in both $N$. tenuis and M. pygmaeus on sweet pepper and occupied 33\% and 14\% of total time spent 
on the plant, respectively. The punctures caused by mirid plant feeding induced the release of a blend of Volatile Organic Compounds (VOCs) which repelled the herbivore pests F. occidentalis and B. tabaci, whereas attracted the whitefly parasitoid E. formosa. The repellent effect on B. tabaci was observed for at least 7 days after initial exposure of the plant to $N$. tenuis, and attraction of E. formosa remained functional for 14 days. Feeding induced plant defences by mirid predators, their subsequent effects on both pests and natural enemy behaviour, and the persistence of these observed effects open the door to new control strategies in sweet pepper crop. Further application of this research is discussed within this chapter, such as the vaccination of plants by zoophytophagous mirids in the nursery before transplantation.

A next step to integrate the possible use of these mirids on sweet pepper BC practices would be to ascertain their potential control on the whitefly B. tabaci and the thrips F. occidentalis. In the third objective of this $\mathrm{PhD}$, a comparative study to measure the efficacy of predation by $N$. tenuis, M. pygmaeus, and Dicyphus maroccanus Wagner (Hemiptera: Miridae) on the two sweet pepper key pests mentioned above, was conducted. This study was carried out under two greenhouses with different temperatures, $20{ }^{\circ} \mathrm{C}$ and $27^{\circ} \mathrm{C}$, which simulated the mean temperature registered in the two main crop cycles in Spain (the winter and summer planting period). Both, $N$. tenuis and M. pygmaeus, were able to establish on sweet pepper and significantly reduced the number of F. occidentalis and B. tabaci adults, larvae and nymphs. Macrolophus pygameus has the highest density at $20^{\circ} \mathrm{C}$, whereas $N$. tenuis was more abundant at $27^{\circ} \mathrm{C}$. In contrast, D. maroccanus did not achieve the required level of control and from our observation could not be selected as a biocontrol agent for F. occidentalis and B. tabaci in this crop. 
None of the three mirids were observed to cause any damage on the pepper plant. The implications of these results for the use of mirids in sweet pepper crops were discussed within this chapter.

In the fourth objective of this $\mathrm{PhD}$, the practical integration of one of these two predatory mirids with $A$. swirskii to enhance sweet pepper pest management was studied. Firstly, the co-occurrence of both mirid species when released together with $A$. swirskii in presence and absence of Ephestia kuehniella Zeller (Lepidoptera: Pyralidae) eggs as alternative prey was investigated. This was compared to the standard release of O. laevigatus with A. swirskii. Secondly, the efficiency of each combined release (either $N$. tenuis, M. pygmaeus or O. laevigatus combined with $A$. swirskii) in reducing F. occidentalis, B. tabaci and the aphid Myzus persicae Sulzer (Hemiptera: Aphididae) infestations was evaluated under greenhouse conditions. Both, N. tenuis and A. swirskii were involved in a bidirectional intraguild predation(IGP). Contrary, this interaction(IGP) was apparently unidirectional in the case of M. pygmaeus with A. swirskii and O. laevigatus with A. swirskii. Both, M. pygmaeus and O. laevigatus significantly reduced the abundance of $A$. swirskii. However, in the greenhouse, IGP seemed to be neutralized. Mirids with $A$. swirskii significantly suppressed thrips, whitefly and aphid infestation, suggesting complementarity in the effects of these two predator species. Contrary, the combined use of O. laevigatus with A. swirskii did not reached a satisfactory control for aphids, despite it reduced effectively the level of thrips and whiteflies. Therefore, our results suggest that the use of mirids, instead of $O$. laevigatus, combined with $A$. swirskii, could result in more efficient and robust $\mathrm{BC}$ programs in sweet pepper crops. 
In summary, together with the newly discovered ability of predatory mirids to induce plant defences, we expect that future BC of sweet pepper in commercial greenhouse could rely on the release of $A$. swirskii with predatory mirids. What is clear is that the use of mirids in sweet pepper is possible and can be more effective than the current system based on O. laevigatus, which motivates me to suggest that mirids deserve more attention in the BC of sweet pepper pests. 



\section{Resumen}

Durante la última década, los programas de gestión integrada de plagas (GIP) basados en el aumento y la conservación de depredadores zoofitófagos se han desarrollado con éxito en invernaderos hortícolas. En pimiento dulce, la liberación de Amblyseius swirskii Athias-Henriot (Acari: Phytoseiidae) y Orius laevigatus Fieber (Hemiptera: Anthocoridae) ha proporcionado un control efectivo de dos plagas clave, el trips Frankliniella occidentalis Pergande (Thysanoptera: Tripidae) y la mosca blanca Bemisia tabaci Gennadius (Hemiptera: Aleyrodidae). A pesar de ser un depredador zoofitófago, el comportamiento fitófago de O. laevigatus no ha sido explorado previamente en profundidad, ni ha tenido un impacto de fitofagia sobre la fisiología de las plantas. En el primer objetivo de esta tesis doctoral, se comparó la importancia jerárquica de la alimentación de O. laevigatus con otros comportamientos sobre pimiento. Orius laevigatus pasó la mayor parte de su tiempo (38\%) alimentándose de meristemo apical y hojas frescas apicales, las cuales también fueron su ubicación preferida. Se ha demostrado que el comportamiento fitófago de O. laevigatus en pimiento desencadena respuestas defensivas en la planta, las cuales contribuyen a la repelencia o atracción de plagas o enemigos naturales, respectivamente. Específicamente, las plantas de pimiento picadas con O. laevigatus inducen una repelencia a mosca blanca B. tabaci y al trips F. occidentalis. Por el contrario, el parasitoide de mosca blanca Encarsia formosa Gahan (Hymenoptera: Aphelinidae) se ve significativamente atraído por plantas picadas con O. laevigatus. Las respuestas 
de la planta al comportamiento fitófago de O. laevigatus incluye la liberación de una mezcla alterada de compuestos volátiles y la activación de las vías de señalización del ácido jasmonato y ácido salicílico. Estos resultados ponen de manifiesto una faceta interesante de la biología de O. laevigatus, en la cual la capacidad del depredador para inducir respuestas defensivas en las plantas de pimiento puede servir para mejorar el control biológico (CB) del trips y la mosca blanca. De hecho, los resultados podrían explicar el gran éxito logrado por los programas de GIP basados en la liberación, el establecimiento y la conservación de O. laevigatus en el cultivo de pimiento.

Sin embargo, el control de plagas en pimiento todavía tiene problemas debido a los pulgones. Actualmente, para mantener la población de pulgones por debajo del umbral económico, se necesita múltiples liberaciones de enemigos naturales especializados. Esta estrategia resulta en una red trófica complicada debido a la gran cantidad de especies liberadas, además de cara para los productores. En los últimos años, la búsqueda de enemigos naturales alternativos para pulgones y que puedan ser integrados con las prácticas actuales de $\mathrm{CB}$ en pimiento ha sido una de las prioridades en la investigación sobre este cultivo. Siguiendo esta línea, el papel de los míridos depredadores (Hemiptera: Miridae) en el manejo de pulgones en pimiento ha sido destacado en varios estudios. Además de sus servicios como depredadores, los miridos zoofitófagos pueden inducir defensas en las plantas debido a su fitofagia. Sin embargo, hasta ahora no se sabe si esta inducción se produce en el pimiento y si podría ser un beneficio adicional a su papel como agente de CB en este cultivo. Estas preguntas se abordaron en el segundo objetivo de esta tesis doctoral y estudiaron sobre dos especies de míridos modelo y comerciales actualmente, Nesidiocoris tenuis Reuter y 
Macrolophus pygmaeus Rambur. El comportamiento de fitofagia sobre la planta de pimiento se observó tanto en $N$. tenuis como en $M$. pygmaeus y ocuparon el 33\% y el 14\% del tiempo total que estuvieron sobre ésta, respectivamente. Las picaduras alimenticias de los míridos indujeron la liberación de una mezcla de Compuestos Orgánicos Volátiles (COV) que repelieron los herbívoros F. occidentalis y B. tabaci y atrajeron al parasitoide de mosca blanca E. formosa. El efecto repelente sobre B. tabaci se observó durante al menos 7 días después de la exposición inicial de la planta a $N$. tenuis y la atracción de E. formosa permaneció funcional durante 14 días. Las defensas inducidas en planta debido a las picaduras alimenticias por míridos depredadores y la persistencia de estos efectos abren la puerta a nuevas estrategias de control de plagas en pimiento. La aplicación adicional de esta investigación se analiza en este capítulo, como la vacunación de plantas por míridos zoofitófagos en el vivero antes del trasplante.

Un siguiente paso para integrar el posible uso de estas dos especies de míridos en las prácticas de $\mathrm{CB}$ de pimiento fue determinar su posible control sobre la mosca blanca B. tabaci y el trips F. occidentalis. En el tercer objetivo de esta tesis doctoral, se llevó a cabo un estudio comparativo para estudiar la eficacia de depredación por N. tenuis, M. pygmaeus y Dicyphus maroccanus Wagner (Hemiptera: Miridae) sobre las dos plagas clave de pimiento mencionadas anteriormente. Este estudio se llevó a cabo en dos invernaderos con diferentes temperaturas, a $20^{\circ} \mathrm{C}$ y $27^{\circ} \mathrm{C}$, que simularon la temperatura media registrada en los dos principales ciclos de cultivo en España (el período de siembra de invierno y de verano). Ambos, N. tenuis y M. pygmaeus, pudieron establecerse en pimiento y redujeron significativamente el número de adultos, larvas y ninfas de F. occidentalis y B. tabaci. Macrolophus pygameus 
tiene la densidad más alta a $20^{\circ} \mathrm{C}$, mientras que $N$. tenuis es más abundante a $27^{\circ} \mathrm{C}$. Por el contrario, D. maroccanus no alcanzó el nivel de control requerido y por tanto no sería seleccionado como agente de CB de F. occidentalis y B. tabaci en este cultivo. Ninguno de los tres míridos se observó que causa ningún daño en la planta de pimiento. Las implicaciones de estos resultados para el uso de los miridos en los cultivos de pimiento se han discutido en este capítulo.

En el cuarto objetivo de esta tesis doctoral, se estudió la integración práctica de uno de estos dos míridos depredadores con $A$. swirskii para mejorar el manejo de plagas en pimiento. En primer lugar, se investigó la coexistencia de ambas especies de miridos cuando se liberaron junto con A. swirskii en presencia y ausencia de huevos de Ephestia kuehniella Zeller (Lepidoptera: Pyralidae) como presa alternativa. Esto se comparó con la versión estándar de uso que consta en la liberación de O. laevigatus con A. swirskii. En segundo lugar, la eficacia de cada liberación combinada (ya sea $N$. tenuis, M. pygmaeus u O. laevigatus combinada con $A$. swirskii) en la reducción de F. occidentalis, B. tabaci y el pulgón Myzus persicae Sulzer (Hemiptera: Aphididae) fue evaluado en condiciones de invernadero. Ambos, $N$. tenuis y A. swirskii estuvieron involucrados en una depredación intragremial bidireccional (DIG). Contrariamente, esta interacción DIG fue aparentemente unidireccional en el caso de $M$. pygmaeus con $A$. swirskii y O. laevigatus con A. swirskii. Ambos, M. pygmaeus y O. laevigatus redujeron significativamentela abundancia de $A$. swirskii.Sinembargo, en el invernadero, la DIG pareció estar neutralizada. El uso de miridos con $A$. swirskii suprimió significativamente el trips, la mosca blanca y la infestación de pulgones, sugiriendo complementariedad en los efectos de estas dos especies de 
depredadores. Contrariamente, el uso combinado de O. laevigatus con A. swirskii no alcanzó un control satisfactorio para los pulgones, a pesar de que redujo efectivamente el nivel de trips y moscas blancas. Por lo tanto, nuestros resultados sugieren que el uso de mirids, en lugar de O. laevigatus, combinado con A. swirskii, podría resultar en programas de CB más eficientes y robustos en el cultivo de pimiento.

En resumen y junto a la capacidad por parte de los míridos zoofitófagos de inducir defensas en plantas, esperamos que el futuro $C B$ de pimiento en invernadero comercial pueda contar con la liberación de $A$. swirskii con míridos predadores. Lo que está claro es que el uso de miridos zoofitófagos en el pimiento es posible y puede ser más efectivo que el sistema actual basado en la liberación de O. laevigatus, lo que me motiva a sugerir que los míridos merecen más atención en el $\mathrm{CB}$ de plagas en pimiento. 



\section{Resum}

Durant l'última dècada, els programes de gestió integrada de plagues (GIP) basats en l'augment i la conservació de depredadors zoofitòfags s'han desenvolupat amb èxit en hivernacles hortícoles. En pebrot, l'alliberament de Amblyseius swirskii Athias-Henriot (Acari: fitoseid) i Orius laevigatus Fieber (Hemiptera:Anthocoridae) ha proporcionatun control efectiu de dues plagues clau, el trips Frankliniella occidentalis Pergande (Thysanoptera: Tripidae) i la mosca blanca Bemisia tabaci Gennadius (Hemiptera: aleiròdid). Tot i ser un depredador zoofitòfag, el comportament fitòfag d'O. laevigatus no ha estat explorat prèviament en profunditat, ni ha tingut un impacte de la fitofagia sobre la fisiologia de les plantes. En el primer objectiu d'aquesta tesi doctoral, es va comparar la importància jeràrquica de l'alimentació d'O. laevigatus amb altres comportaments sobre pebrot. Orius laevigatus va passar la major part del seu temps (38\%) alimentant-se del meristem apical i de les fulles fresques apicals, les quals també van ser la seva ubicació preferida. S’ha demostrat que el comportament fitòfag d'O. laevigatus en pebrot desencadena respostes defensives a la planta, les quals contribueixen a la repel.lència o l'atracció de plagues o enemics naturals, respectivament. Específicament, les plantes de pebrot picades amb O. laevigatus indueixen una repelència a la mosca blanca B. tabaci i al trips F. occidentalis. Per contra, el parasitoid de mosca blanca Encarsia formosa Gahan (Hymenoptera: Aphelinidae) es veu significativament atret per plantes picades amb O. laevigatus. Les respostes de la planta al comportament fitòfag d'O. laevigatus inclou l'alliberament d'una barreja 
alterada de compostos volàtils i l'activació de les vies de senyalització de l'àcid jasmonic i l'àcid salicílic. Aquests resultats posen de manifest una faceta interessant de la biologia d'O. laevigatus, en la qual la capacitat del depredador per induir respostes defensives en les plantes de pebrot pot servir per millorar el control biològic (CB) del trips i la mosca blanca. De fet, els resultats podrien explicar el gran èxit assolit pels programes de GIP basats en l'alliberament, l'establiment i la conservació d'O. laevigatus en el cultiu de pebrot.

No obstant això, el control de plagues en pebrot encara té problemes a causa dels pugons. Actualment, per mantenir la població de pugons per sota del llindar econòmic, es necessita múltiples alliberaments d'enemics naturals especialitzats. Aquesta estratègia resulta en una xarxa tròfica complicada a causa de la gran quantitat d'espècies alliberades, a més de cara per als productors. En els últims anys, la recerca d'enemics naturals alternatius per pugons i que puguin ser integrats amb les pràctiques actuals de $\mathrm{CB}$ en pebrot ha estat una de les prioritats en la investigació sobre aquest cultiu. Seguint aquesta línia, el paper dels mírids depredadors (Hemiptera: Miridae) en el maneig de pugons en pebrot ha estat destacat en diversos estudis. A més dels seus serveis com a depredadors, els mírids zoofitòfags poden induir defences a les plantes a causa de la seva fitofagia. No obstant això, fins ara no se sap si aquesta inducció es produeix en el cultiu del pebrot $\mathrm{i}$ si podria ser un benefici addicional al seu paper com a agent de CB en aquest cultiu. Aquestes preguntes es van abordar en el segon objectiu d'aquesta tesi doctoral i estudiar sobre dues espècies de mírids model i comercials actualment, Nesidiocoris tenuis Reuter i Macrolophus pygmaeus Rambur. El comportament de fitofagia sobre la planta de pebrot es va observar tant 
en $N$. tenuis com a $M$. pygmaeus i van ocupar el 33\% i el 14\% del temps total que van estar sobre aquesta, respectivament. Les picades alimentàries dels mírids van induir l'alliberament d'una barreja de compostos orgànics volàtils (COV) que van repel-lir els herbívors F. occidentalis i B. tabaci i van atreure al parasitoid de mosca blanca E. formosa. L'efecte repel-lent sobre B. tabaci es va observar durant almenys 7 dies després de l'exposició inicial de la planta a $N$. tenuis i l'atracció d'E. formosa romandre funcional durant 14 dies. Les defenses induïdes en planta a causa de les picades alimentàries per mírids depredadors i la persistència d'aquests efectes obren la porta a noves estratègies de control de plagues en pebrot. L'aplicació addicional d'aquesta investigació s'analitza en aquest capítol, com la vacunació de plantes per mírids zoofitófagos al viver abans del trasplantament.

Un següent pas per integrar el possible ús d'aquestes dues espècies de mírids en les pràctiques de $\mathrm{CB}$ de pebrot va ser determinar la seva possible control sobre la mosca blanca B. tabaci i el trips F. occidentalis. En el tercer objectiu d'aquesta tesi doctoral, es va dur a terme un estudi comparatiu per estudiar l'eficàcia de depredació de N. tenuis, M. pygmaeus i Dicyphus maroccanus Wagner (Hemiptera: Miridae) sobre les dues plagues clau de pebrot esmentades anteriorment. Aquest estudi es va dur a terme en dues hivernacles amb diferents temperatures, a $20^{\circ} \mathrm{C}$ i $27^{\circ} \mathrm{C}$, que van simular la temperatura mitjana registrada en els dos principals cicles de cultiu a Espanya (el període de sembra d'hivern i d'estiu). Tots dos, N. tenuis i M. pygmaeus, van poder establir-se en pebrot $\mathrm{i}$ van reduir significativament el nombre d'adults, larves i nimfes de F. occidentalis i B. tabaci. Macrolophus pygameus té la densitat més alta a $20^{\circ} \mathrm{C}$, mentre que $N$. tenuis és més abundant a $27{ }^{\circ} \mathrm{C}$. Per contra, D. maroccanus no va aconseguir el nivell de control requerit i així 
no seria seleccionat com a agent de CB de F. occidentalis i $B$. tabaci en aquest cultiu. Cap dels tres mírids es va observar que causa cap dany a la planta de pebrot. Les implicacions d'aquests resultats per a l'ús dels mírids en els cultius de pebrot s'han discutit en aquest capítol.

En el quart objectiu d'aquesta tesi doctoral, es va estudiar la integració pràctica d'un d'aquests dos mírids depredadors amb A. swirskii per millorar el maneig de plagues en pebrot. En primer lloc, es va investigar la coexistència de les dues espècies de mírids quan es van alliberar juntament amb A. swirskii en presència i absència d'ous de Ephestia kuehniella Zeller (Lepidoptera: Pyralidae) com a presa alternativa. Això es va comparar amb la versió estàndard d'ús que consta en l'alliberament d'O laevigatus amb A. swirskii. En segon lloc, l'eficàcia de cada alliberament combinada (ja sigui $N$. tenuis, M. pygmaeus o O. laevigatus combinada amb A. swirskii) en la reducció de F. occidentalis, B. tabaci i el pugó Myzus persicae Sulzer (Hemiptera: Aphididae) va ser avaluat en condicions d'hivernacle. Tots dos, N. tenuis i A. swirskii van estar involucrats en una depredació intragremial bidireccional (DIG). Contràriament, aquesta interacció DIG va ser aparentment unidireccional en el cas de M. pygmaeus amb A. swirskii i O. laevigatus amb A. swirskii. Tots dos, M. pygmaeus i O. laevigatus van reduir significativament l'abundància d'A. swirskii. No obstant això, a l'hivernacle, la DIG va semblar estar neutralitzada. L'ús de mírids amb A. swirskii va suprimir significativament el trips, la mosca blanca i la infestació de pugons, suggerint complementarietat en els efectes d'aquestes dues espècies de depredadors. Contràriament, 1'ús combinat d'O. laevigatus amb A. swirskii no va aconseguir un control satisfactori per als pugons, tot i que va reduir efectivament el nivell de trips i mosques blanques. Per tant, els nostres 
resultats suggereixen que l'ús de mirids, en lloc d'O. laevigatus, combinat amb A. swirskii, podria resultar en programes de CB més eficients i robustos en el cultiu de pebrot.

En resum i junt la capacitat per part dels mírids zoofitòfags d'induir defenses en plantes, esperem que el futur del CB de pebrot en hivernacle comercial pugui comptar amb l'alliberament d'A. swirskii amb mírids depredadors. El que està clar és que l'ús de mírids zoofitòfags en el pebrot és possible i pot ser més efectiu que el sistema actual basat en l'alliberament d'O. laevigatus, el que em motiva a suggerir que els mírids mereixen més atenció en el CB de plagues en pebrot. 



\section{Table of Content}

Chapter 1. General Introduction ...............................................................1

1.1. Sweet pepper crop ....................................................................................

1.1.1. Economic importance..............................................................................

1.1.2. Pest status in protected sweet pepper..................................................

1.1.3. Current status of biological control in sweet pepper ........................12

1.1.3.1. Amblyseius swirskii ........................................................................13

1.1.3.2. Orius laevigatus............................................................................15

1.1.4. Gaps in the biological control of aphids..............................................17

1.2. Zoophytophagous predators ...........................................................................19

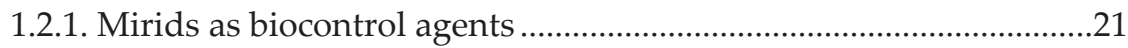

1.2.2. Phytophagous behaviour of mirid predators .......................................25

1.2.3. Plant damage by mirid predators.........................................................29

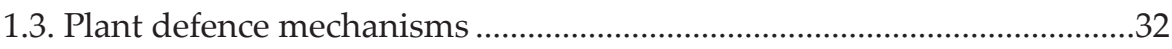

1.3.1. Herbivore induced plant volatiles (HIPVs) .........................................36

1.3.2. Zoophytophagous predator induced plant defence...........................40

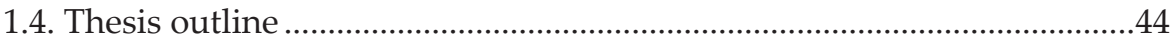

Chapter 2. Orius laevigatus Strengthens its Role as a Biological Control Agent by Inducing Plant Defences

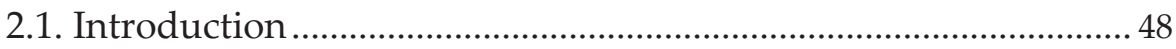

2.2. Material and methods .................................................................... 50

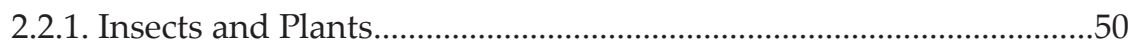


2.2.2. Behaviour of $O$. laevigatus on sweet pepper.......................................51

2.2.3. Plant selection mediated by O. laevigatus...........................................53

2.2.4. Plant gene expression analysis............................................................54

2.2.5. Composition of volatile blends.........................................................56

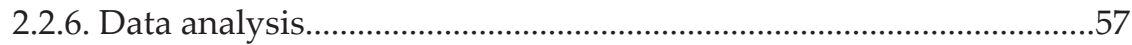

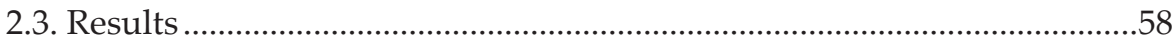

2.3.1. Behaviours and locations of $O$. laevigatus on sweet pepper .............58

2.3.2. Plant selection mediated by O. laevigatus ............................................59

2.3.3. Plant gene expression analysis...........................................................60

2.3.4. Composition of volatile blends ...........................................................62

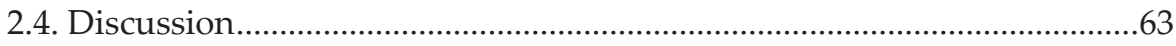

Chapter 3. Zoophytophagous Mirids Provide Pest Control by Inducing Direct Defences, Antixenosis and Attraction to Parasitoids in Sweet Pepper Plants .......................................................69

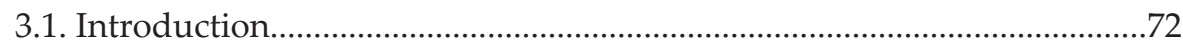

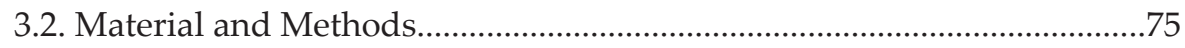

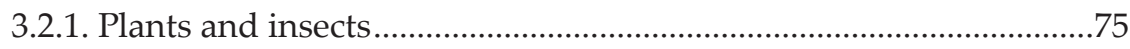

3.2.2. Mirid behaviour on sweet pepper......................................................76

3.2.3. Phytohormone analysis and plant gene expression ...........................77

3.2.4. Determination of plant volatile compounds........................................79

3.2.5. Response to induced sweet pepper plants...........................................81

3.2.6. Persistence of plant induction...................................................................82

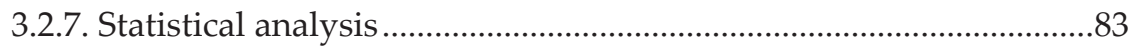

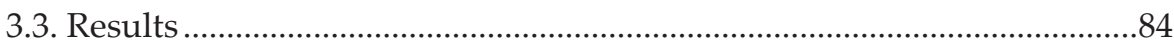

3.3.1. Mirid behaviour on sweet pepper.........................................................84

3.3.2. Mirids impact both ABA and JA signaling pathways.......................86 
3.3.3. Mirids significantly altered the volatile blend following inoculation

3.3.4. Mirid infestation triggers parasitic wasp attraction and induces pest antixenosis .88

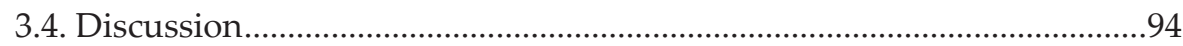

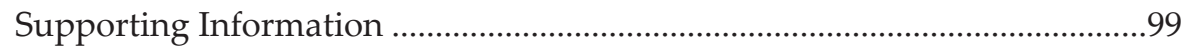

Chapter 4. Comparative biocontrol potential of three predatory mirids when preying on sweet pepper key pests.......101

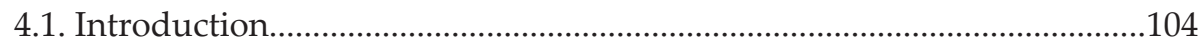

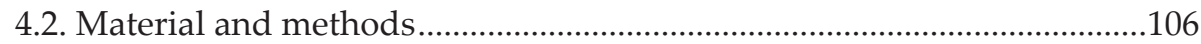

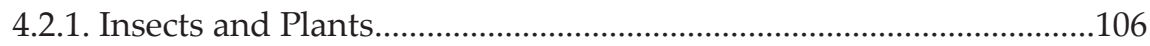

4.2.2. Experimental design and sampling ....................................................108

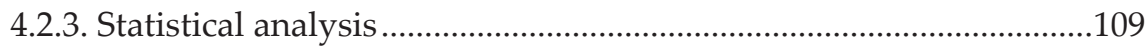

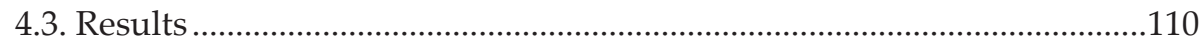

4.3.1. Frankliniella occidentalis management...................................................110

4.3.2. Bemisia tabaci management .................................................................113

4.3.3. Mirid populations ..................................................................................115

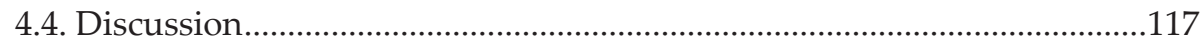

Chapter 5. Combined use of predatory mirids with Amblyseius swirskii to enhance pest management in sweet

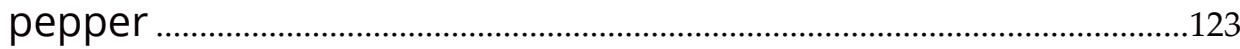

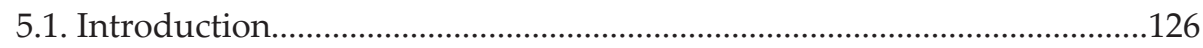

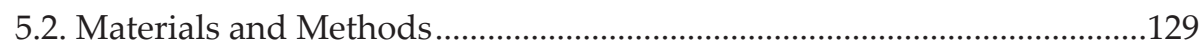

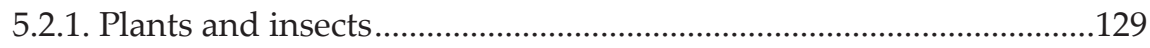

5.2.2. Co-occurrence between predatory bugs and A. swirskii ...................130 
5.2.3. Greenhouse efficacy experiment

5.2.4. Statistical analysis

5.3. Results

5.3.1. Dynamics of predatory bugs when co-occurred with A. swirskii ...135

5.3.2. Dynamics of $A$. swirskii when co-occurred with predatory bugs ....138

5.3.3. Predators abundance under greenhouse conditions 139

5.3.4. Pest management 140

5.4. Discussion 143

Chapter 6. General Discussion and Conclusions 147

Chapter 7. References 159 


\section{List of Figures}

Figure 1.1. Sweet pepper key pests, Frankliniella occidentalis (A, D), Bemisia tabaci (B, E, F), Myzus persicae (C, F, G).

Figure 1.2. Sweet pepper area (ha) under BC (A); Percentage of farms with BC (B) (Almería region)

Figure 1.3. Adut Amblyseius swirskii.....

Figure 1.4. Female Orius laevigatus laying eggs (A), Eggs of O. laevigatus inserted in sweet pepper stem (B), First instar nymph (N1) (C), Adult (D).

Figure 1.5. Developmental stages of Nesidiocoris tenuis, $1^{\text {st }}$ instar (N1) (A), $2^{\text {nd }}$ instar (N2) (B), $3^{\text {rd }}$ instar (N3) (C), $4^{\text {th }}$ instar (N4) (D), $5^{\text {th }}$ instar (N5) (E), Adult (F), Female laying eggs $(\mathrm{G})$, Egg of $N$. tenuis inserted in sweet pepper stem $(\mathrm{H})$

Figure 1.6. Developmental stages of Macrolophus pygmaeus, $1^{\text {st }}$ instar (N1) (A), $2^{\text {nd }}$ instar (N2) (B), $3^{\text {rd }}$ instar (N3) (C), $4^{\text {th }}$ instar (N4) (D), $5^{\text {th }}$ instar (N5) (E), Adult (F)

Figure 1.7. Model of plant-insect herbivore interactions and associated chemical defence mechanisms. Feeding insects above and below ground face direct chemicals defence responses. Indirect defences are represented by extrafloral nectar that can attract ants or natural enemies to defend the plant by the emission of volatile organic compounds....

Figure 1.8. Illustration of milestone articles that depicts the chronology in the discovery of the herbivore induced volatile organic compound (HIPVs) releases that act on the receivers: interplant communication (Baldwin and Schultz, 1983; Rhoades, 1985), predatory mites (Dicke and Sabelis, 1988), parasitoid wasps (Turlings et al., 1990), predatory bugs (Drukker et al., 1995), predatory lady beetles (Ninkovic et al., 2001), herbivorous moths, which are repelled (de Moraes et al., 2001), parasitic plants (Runyon et al., 2006), nematodes (Rasmann et al., 2005), systemic parts of the same plant (Karban et al., 2006), predatory birds (Mäntylä et al., 2008), resistance to pathogens (Yi et al., 2009) and hyperparasitoid (Poelman et al., 2012). Predatory bugs (N. tenuis and M. pygmaeus) induced VOCs via plant feeding behaviour (Pérez-Hedo et al., 2015a; Pappas et al., 2015)

Figure 2.1. Residence time (mean \pm SE) of O. laevigatus adults on sweet pepper plants. Bars with different letters are significantly different (ANOVA, Tukey's multiple comparison test $\alpha<0.05)(n=40)$. 
Figure 2.2. Time (mean \pm SE) spent exhibiting different behaviours by O. laevigatus adults on sweet pepper plants during a period of $30 \mathrm{~min}$. Bars with different letters are significantly different (ANOVA, Tukey's multiple comparison test $\alpha<0.05)(\mathrm{n}=40)$.

Figure 2.3. Response in Y-tube olfactometer of females of F. occidentalis $(n=33)$, B. tabaci $(\mathrm{n}=33)$ and E. formosa $(\mathrm{n}=34)$ to the odor emitted by intact sweet pepper and by sweet pepper plants previously exposed to O. laevigatus. Significant differences based on a $\chi 2$-test are marked using * $(P<0.05)$.

Figure 2.4. Transcriptional response of the defensive genes ASR1 (a), PIN2 (b) and PR1 (c) responsible for the change in level of the phytohormones ABA, JA, and SA, respectively, in O. laevigatus- punctured plants. Data are presented as the mean of eight independent analyses of transcript expression relative to a housekeeping gene \pm SE $(n=8)$. Significant differences based on $t$ - test are marked with $\left(^{*}\right)(P<0.05)$.......

Figure 3.1. Comparison between the phytohormone levels in the apical regions of intact sweet pepper plants, $N$. tenuis-punctured plants and M. pygmaeus-punctured plants, (a) ABA, (b) SA, (c) JA and (d) JA-lle. The presented results are the mean hormone level of five independent analyses $\pm S E(n=5)$. Bars with different letters are significantly different (ANOVA, Tukey's multiple comparison test $\alpha<0.05$ )

Figure 3.2. Quantification of defensive genes in the apical regions of intact sweet pepper plants, $N$. tenuis-punctured plants and M. pygmaeus-punctured plants, (a) ASR1, (b) PIN2 and (c) PR1. Data are presented as the mean of eight independent analyses of transcript expression relative to a housekeeping gene \pm SE $(n=8)$. Bars with different letters are significantly different (ANOVA, Tukey's multiple comparison test $\alpha<0.05)$.

Figure 3.3. Olfactory response of the selected insects to mirids-punctured plants in comparison to intact plants. (a) Response of F. occidentalis $(n=36)$, B. tabaci $(n=41)$ and E. formosa $(\mathrm{n}=30)$ in the $\mathrm{Y}$-tube olfactometer when exposed to intact sweet pepper plants and N. tenuis-punctured plants. (b) Response of F. occidentalis $(\mathrm{n}=36), B$. tabaci $(\mathrm{n}=39)$ and E. formosa $(\mathrm{n}=30)$ in the $\mathrm{Y}$-tube olfactometer when exposed to intact sweet pepper plants and M. pygmaeus-punctured plants. Significant differences based on a $\chi 2$-test are marked using * $(P<0.05)$.

Figure 3.4. Herbivores choice between mirid punctured plants and intact plants. (a) Number of $F$. occidentalis adults per plant $(X \pm S E)$ captured 24 hours after releasing $100 \mathrm{~F}$. occidentalis in the centre of a cage containing 3 intact plants and 3 N. tenuis/M. pygmaeus-punctured plants. (b) Number of B. tabaci adults per plant $(X \pm S E)$ captured 24 hours after releasing $100 \mathrm{~B}$. tabaci in the centre of a cage containing 3 intact plants and $3 \mathrm{~N}$. tenuis/M. pygmaeus-punctured plants. Both mirid species were in contact with the plants only $24 \mathrm{~h}$ and then removed. Significant difference resulting from a one tailed $t$-test are marked with $\left(^{*}\right)(P<0.05) \ldots \ldots . .91$ 
Figure 3.5. Persistence of sweet pepper induction following $N$. tenuis punctures. (a) Response of E. formosa and B. tabaci, respectively to $N$. tenuis-punctured plants vis intact plants after 4 days, 7 days and 14 days exposure ended. Significant differences based on a $\chi^{2}$-test are marked using ${ }^{*}(P<0.05)$. (b) Relative expression of defensives genes ASR1, PIN2 and PR1 in intact sweet pepper plants with comparison to $N$. tenuis-punctured plants, 14 days after exposure ended. Data are presented as the mean of eight independent analyses of transcript expression relative to the constitutive $E F 1$ gene $\pm S E(n=8)$. Significant difference from a one tailed $t$-test are marked with $\left(^{*}\right)(P<0.05)$.

Figure 4.1. (a) Number (mean $\pm \mathrm{SE}$ ) of $F$. occidentalis (adults + larvae) per sweet pepper leaf at $20^{\circ} \mathrm{C}$, (b) percentage reduction (Abbott) (mean $\pm \mathrm{SE}$ ) of $F$. occidentalis individuals at $20^{\circ} \mathrm{C}$, (c) number (mean $\pm \mathrm{SE}$ ) of F. occidentalis (adults + larvae) per sweet pepper leaf at $27^{\circ} \mathrm{C}$, and (d) percentage reduction (Abbott) (mean $\pm \mathrm{SE}$ ) of $F$. occidentalis individuals at $27^{\circ} \mathrm{C}$ in a glasshouse experiment comparing the effectiveness of the mirid predators, $N$. tenuis, M. pygmaeus, and D. maroccanus at different time intervals under the two temperature regimes mentioned above. Bars with different letters are significantly different (ANOVA, Tukey's multiple comparison test $\alpha<0.05)$

Figure 4.2. (a) Number (mean $\pm \mathrm{SE}$ ) of $B$. tabaci (adults + nymphs) per sweet pepper leaf at $20^{\circ} \mathrm{C}$, (b) percentage reduction (Abbott) (mean $\pm \mathrm{SE}$ ) of $\mathrm{B}$. tabaci individuals at $20{ }^{\circ} \mathrm{C}$ (c) Number (mean \pm SE) of $B$. tabaci (adults + nymphs) per sweet pepper leaf at $27^{\circ} \mathrm{C}$, and (d) percentage reduction (Abbott) (mean \pm $\mathrm{SE}$ ) of $\mathrm{B}$. tabaci individuals at $27^{\circ} \mathrm{C}$ in a glasshouse experiment comparing the effectiveness of the mirid predators, $N$. tenuis, M. pygmaeus, and D. maroccanus at different time intervals under the two temperature regimes mentioned above. Bars with different letters are significantly different (ANOVA, Tukey's multiple comparison test $\alpha<0.05$ )

Figure 4.3. Number (mean $\pm \mathrm{SE}$ ) of $N$. tenuis, M. pygmaeus, and D. maroccanus (adults + nymphs) per sweet pepper plants at different time intervals under two temperature regimes (a) $20^{\circ} \mathrm{C}$ and (b) $27^{\circ} \mathrm{C}$

Figure 5.1. Timeline representing mirid inoculation, $A$. swirskii and O. laevigatus introduction, pest infestation and insect abundance, data collection during the greenhouse experiment

Figure 5.2. Variation in the abundance of predatory bug (a) $N$. tenuis (Nt), (b) M. pygmaeus $(\mathrm{Mp})$ and (c) O. laevigatus $(\mathrm{Ol})$ (adults + nymphs, mean number \pm SE) per sweet pepper plant in single species treatment and in mixed treatment with $A$. swirskii $(A s)$ when the shared prey E. kuehniella $(E k)$ eggs were and were not provided. Different letters indicate significant differences of predator bug numbers of the same species between treatments

Figure 5.3. Variation in the abundance of A. swirskii (As) (adults + deutonymph + protonymph + nymphs, mean number $\pm \mathrm{SE}$ ) per sweet pepper plant in single specie treatment and in mixed treatment with predatory bugs when the shared prey E. kuehniella (Ek) eggs were (a) and were not provided (b). Different letters indicate significant differences of $A$. swirskii numbers between treatments 
Figure 5.4. (a) Dynamics of the predatory bugs' $N$. tenuis (Nt), M. pygmaeus $(M p)$ and $\mathrm{O}$. laevigatus $(\mathrm{Ol})$ (adults + nymphs, mean number $\pm \mathrm{SE}$ ) per sweet pepper plant when released combined with $A$. swirskii. (b) Dynamics of $A$. swirskii $(A s)$ (adults + deutonymph + protonymph + nymphs, mean number \pm SE) per sweet pepper plant in different combined treatments with predatory bugs under greenhouse experimental conditions. Different letters indicate significant differences of predators' numbers between treatments

Figure 5.5. (a) Number (mean $\pm \mathrm{SE}$ ) of F. occidentalis (adults + nymphs) per sweet pepper plant, (b) percentage reduction (Abbott) (mean $\pm \mathrm{SE}$ ) of F. occidentalis individuals (c) Number (mean \pm SE) of $B$. tabaci (adults + nymphs) per sweet pepper plant, (d) percentage reduction (Abbott) (mean \pm SE) of $B$. tabaci individuals, (e) Number (mean $\pm \mathrm{SE}$ ) of $M$. persicae (adults + nymphs) per sweet pepper plant, (f) percentage reduction (Abbott) (mean $\pm \mathrm{SE}$ ) of $M$. persicae individuals in a greenhouse experiment comparing the effectiveness of predatory bug ( $N$. tenuis $(N t)$, M. pygmaeus $(\mathrm{Mp})$ and $\mathrm{O}$. laevigatus $(\mathrm{Ol})$ ) when released in mixed treatment with $A$. swirskii $(A s)$ each, at different time intervals. Bars with different letters are significantly different (ANOVA, Tukey's multiple comparison test $\alpha<0.05$ ) 


\section{List of Tables}

Table 1.1. Main pests and their associated natural enemies in sweet pepper greenhouses

Table 1.2. Host plant species on which Nesidiocoris tenuis and Macrolophus pygmaeus were found

Table 2.1. Forward and reverse sequences of $A S R 1, P I N 2, P R 1$, and the constitutive gene $E F 1$

Table 2.2. Significant relative levels (fold changes) of the volatiles emitted by O. laevigatus punctured plants relative to intact plants. Student's $t$-test $(P<0.05)$

Table 3.1. Time in seconds (mean \pm SE) spent by males and females of $N$. tenuis and $M$. pygmaeus in seven different behavioural states on sweet pepper plant, and the resident time (mean $\pm \mathrm{SE}$ ) of each predator on the three designed locations. Observation were performed during 30 minutes.

Table 3.2. Significant relative levels (fold changes) of the volatiles emitted by $N$. tenuis and M. pygmaeus punctured sweet pepper plants relative to intact plants. One way ANOVA, Tukey's multiple comparison test $(\alpha<0.05)$.....

Table S1. Statistics ( $P, F$ and degree freedom values) for the two-way ANOVA comparison of time spent by males and females of $N$. tenuis and M. pygmaeus in eight different behavioural states on sweet pepper plant, and the resident time of each predator and sex on the three designed locations.

Table 4.1. $P$ values for the pairwise comparison of the number of $F$. occidentalis (adults + larvae) per leaf which received a release of D. maroccanus $(D m)$, M. pygmaeus $(\mathrm{Mp}), \mathrm{N}$. tenuis $(\mathrm{Nt})$ and control without release (C). Values in bold correspond to significant differences between the treatments

Table 4.2. $P$ values for the pairwise comparison of the number of $B$. tabaci (adults + nymphs) per leaf which received a release of $D$. maroccanus $(D m)$, M. pygmaeus $(\mathrm{Mp}), \mathrm{N}$. tenuis $(\mathrm{Nt})$ and control without release $(\mathrm{C})$. Values in bold correspond to significant differences between the treatments.

Table 4.3. $P$ values for the pairwise comparison of the number of mirids (adults + nymphs) per plant that received $D$. maroccanus $(\mathrm{Dm}), \mathrm{M}$. pygmaeus $(\mathrm{Mp})$, and $N$. tenuis $(N t)$ releases. Values in bold correspond to significant differences between the treatments 
Table 5.1. Average of predatory bugs (N. tenuis, M. pygmaeus, O. laevigatus) ( \pm SE) and predatory mites ( \pm SE) accumulated per day when released alone or when combined on plant deprived of or provided with eggs of the alternative shared prey, E. kuehniella. Means in the same row followed by the same letter are not significantly different (Tukey, $P<0.05$; ${ }^{*}$-test, $P<0.05$ )

Table 5.2. P-values for the pairwise comparison of the number of $A$. swirskit (As) and predatory bug (O. laevigatus, N. tenuis, M. pygmaeus) per sweet pepper plant in the following treatments ( $N$. tenuis $+A$. swirskii $(N t+A s)$, M. pygmaeus + A. swirskii $(\mathrm{Mp}+A s)$ and O. laevigatus + A. swirskii $(\mathrm{Ol}+A s))$. Values in bold correspond to significant differences between treatments

Table 5.3. P-values for the pairwise comparison of the number of F. occidentalis, $B$. tabaci and M. persicae per sweet pepper plant that received a release of $N$. tenuis $+A$. swirskii $(N t+A s)$, M. pygmaeus $+A$. swirskii $(M p+A s)$, O. laevigatus $+A$. swirskii $(\mathrm{Ol}+\mathrm{As})$ and control without release $(\mathrm{C})$. Values in bold correspond to significant differences between treatments 


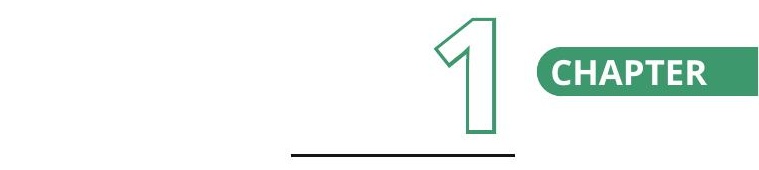

General Introduction 



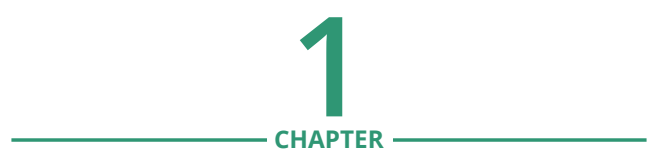

\section{General Introduction}

\subsection{Sweet pepper crop}

Sweet pepper, also known as bell pepper, pepper, or capsicum is a cultivar group of the species Capsicum annuum L., which is a perennial herbaceous plant from the Solanaceae family (nightshade family). Of the family, the genus Capsicum is the second most important vegetable crop in the world, following tomato (Rubatzky and Yamaguchi, 1997a, 1997b). Peppers are native to Mexico, Central America, and northern South America, and have been historically associated with the voyage of Columbus (Heiser, 1976). Pepper seeds were imported to Spain in 1493, since then peppers have spread to other European, African, and Asian countries.

\subsubsection{Economic importance}

Sweet pepper together with tomato is the crop that occupies most of the area among protected species around the world. Pepper cultivation is almost entirely carried out in open fields, however the extension of protected, greenhouse cultivate peppers has intensively increased. China is leading the world production with 16,000,000 tons (FAOSTAT, 2016). Spain occupies the fifth position with $1,130,340$ tons, of which 733,744 tons were exported in 2016, thus, it is ranked as the second exporter in the world after Holland (Hortoinfo, 2017). Last year, the volume of the Spanish 
exported pepper represented $22.3 \%$ of the total world exportation, with a complete value estimated at 990.5 million Euros, at an average price of 1.35 Euros per kilo (MARM, 2017).

In Spain, over 18,513 hectares (ha) are devoted to the production of peppers, wherein Andalusia is the major production region (Hortoinfo, 2017). Approximately two-thirds of the area dedicated to this crop is inside greenhouses while the remaining one-third is cultivated in open fields (Simón et al., 2016). The provinces with the largest area in 2015-2016 were Almeria (9,611 ha), Murcia (1,450 ha), Malaga (580 ha), Granada (300 ha) and Alicante (250 ha) (Hortoinfo, 2017). The province of Almeria is the biggest producer of sweet pepper for export, focusing its production mainly during the autumn and winter months, from September to March. In contrast, the commercialization of sweet pepper in Murcia begins in March and ends in summer. The Murcia production shares the time period and market destination with the Dutch pepper of traditionally high quality (Fernández-Zamudio et al., 2006).

\subsubsection{Pest status in protected sweet pepper}

Sweet pepper is susceptible to several pests which can reduce fruit quality and yield (Table 1.1). Insects and mites associated with pepper can cause both direct and indirect damage (Brodsgaard and Albajes, 1999; Weintraub, 2007). Indirect damage occurs mainly when pests are vectors transmitting viruses, whereas direct damage occurs when pests damage roots, stems, flowers and fruit. As an alternative to exclusively treating pest with insecticides, integrated pest management (IPM) based on biological control (BC) tactics have been successfully adopted in various confined and 
open production areas around the world. The principle sweet pepper pests and their corresponding natural enemies are summarized in table 1.1.

Since Western flower thrips (WFT) Frankliniella occidentalis Pergande (Thysanoptera: Thripidae) (Fig.1.1.A) appeared in Europe it has become one of the most serious pest species of sweet pepper, both in greenhouse and in open field (Tavella et al., 1991; Tommasini and Maini, 1995). Thrips generally prefer to live in closed areas such as the flowers, under the calyx of the fruit and in newly opening leaves, which makes them difficult to reach with insecticides (Fig.1.1.D). With their piercingsucking mouthparts; epidermal and parenchymal cells are punctured by both adults and nymphs, and the contents of the cells sucked out, resulting in silvery chlorotic spots. Direct damage is due to feeding and oviposition on plant leaves, flowers and fruit (Shipp et al., 1998), while indirect damages is caused by virus transmission, of which tomato spotted wilt virus (TSWV) is the most economically important (Ullman et al., 1997). Currently, F. occidentalis has become resistant to major insecticide groups (Bielza, 2008), therefore IPM based on BC is the alternative strategy for the control of WFT (van Lenteren and Loomans, 1998; van Driesche et al., 1998; Riudavets et al., 1993) (Table 1.1).

Considerable damage to the sweet pepper crop is also attributed to two species of whiteflies, the sweet potato whitefly, Bemisia tabaci Gennadius (Fig.1.1.B) and the greenhouse whitefly Trialeurodes vaporariorum Westwood (Hemiptera: Aleyrodidae) (van Lenteren and Woets, 1988). Whitefly adults and nymphs feed on the phloem (Fig.1.1.E,F), causing direct damage. While indirect damage is caused from the adult's virus transmission of, mainly, the Tomato yellow leaf curl virus (TYLCV) by B. tabaci and Tomato infectious chlorosis virus (TICV) by T. vaporariorum, and/or by sooty mould 
which develops on their excreted honeydew, thus, reducing the rate of leaf photosynthesis (Jones, 2003). The developed resistance to several chemical classes of insecticides, including the neonicotinoids which were commonly used for B. tabaci control (Elbert and Nauen, 2000), increase the need for BC of this pest. Several natural enemies are currently used for the management of whiteflies in sweet pepper (Gerling et al., 2001; Naranjo, 2001; Arnó et al, 2010b) (Table 1.1).

Aphids are also among the most problematic pests in protected crops. Several polyphagous species, such as Myzus persicae Sulzer (Fig.1.1.C), Macrosiphum euphorbiae Thomas, Aphis gossypii Glover and Aulacorthum solani Kaltenbach (Hemiptera: Aphididae), are reported to induce considerable damage in sweet pepper (Fig.1.1.F,G) (Blom, 2008; Sánchez et al., 2011). Aphids are difficult to control due to their high reproductive capability and short developmental period which can quickly lead to resistance to many different insecticide classes. Their BC can be successfully achieved by the augmentative release of natural enemies (Table 1.1) and the introduction of banker plants. This is true for A. gossypii and M. persicae which can be well controlled in greenhouse sweet pepper; however, the other two species M. euphorbiae and A. solani are not satisfactory managed (Sánchez et al., 2011; Pérez-Hedo and Urbaneja, 2015). 


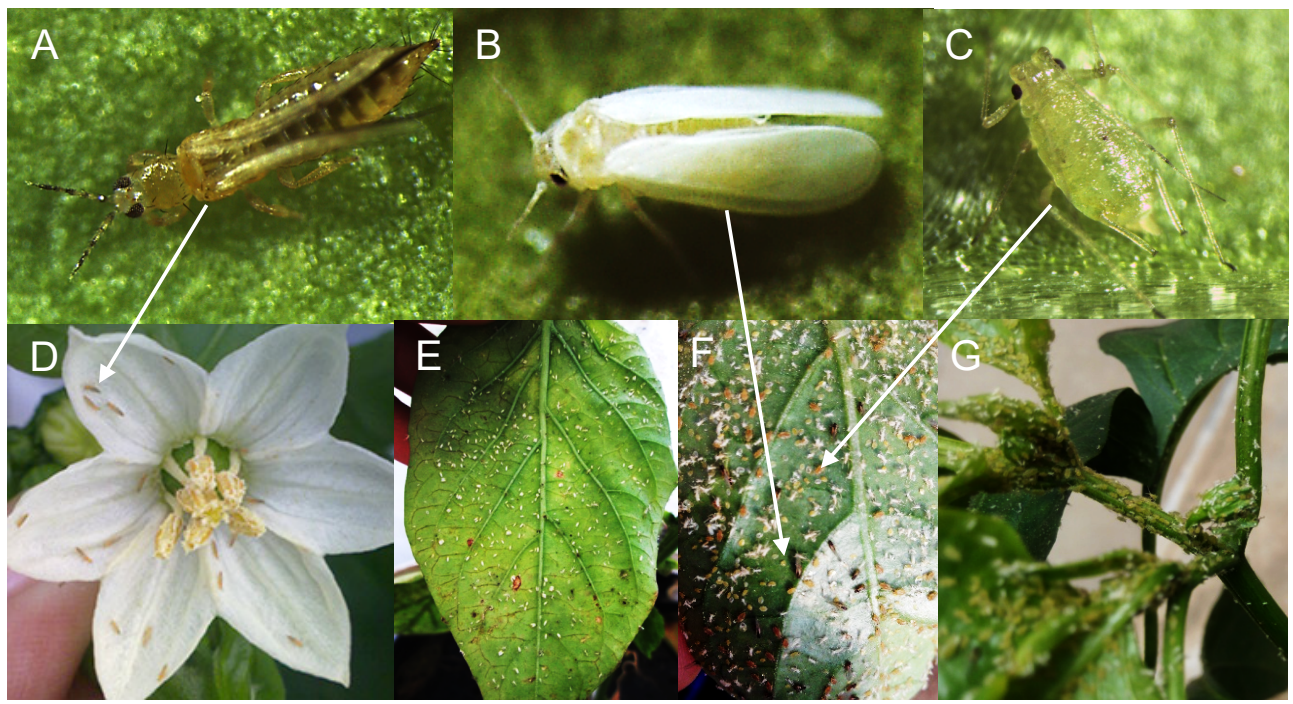

Figure 1.1.

Sweet pepper key pests, Frankliniella occidentalis (A, D), Bemisia tabaci (B, E, F), Myzus persicae (C, F, G).

The two-spotted spider mite Tetranychus urticae Koch (Acari: Tetranychidae) is a common pest in greenhouse pepper (van de Vrie et al., 1972). Damages are related to the pest feeding on the underside of leaves, piercing the chloroplast-containing cells and causing significant injury to the crop. The broad mite, Polyphagotarsonemus latus Banks (Acari: Tarsonemidae), is a destructive pest whose attacks cause serious malformations after injecting toxins in the leaf tissue while feeding. It is very small and difficult to detect, thus, the pest is most often only identified when it has already caused severe economic losses (Coss-Romero and Pena, 1998). Phytoseiidae predatory mites are the main component in the commercial BC programs aimed to control T. urticae and P. latus in sweet pepper (Griffiths, 1999) (Table 1.1). 
Several species of leafminers have become serious pests in pepper growing areas (Table 1.1). Direct damage occurs as a consequence of larval feeding inside the leaf and adult feeding punctures on the upper side of the leaf (Dik et al., 1999). A high amount of leaf mines cause a significant decrease in photosynthetic assimilate production that may lead to desiccation and premature leaf fall. Indirect damage is the result of viral disease transmission and pathogen penetration into the leaves via female feeding punctures. Several natural enemies can develop on the larvae and pupae of the Liriomyza spp. miners (Diptera: Agromyzidae) (Table 1.1), (Onillon, 1999). Many Lepidopteran species of the family Noctuidae cause considerable damage to pepper crops (Dik et al., 1999). For their control locating them in early stages is very pertinent as they live grouped in very specific areas, hiding during the day and feeding during the night (Table 1.1). The green stink bug, Nezara viridula Linnaeus (Hemiptera: Pentatomidae), has recently become one of the main pest in greenhouse pepper cultivation. This bug was easily controlled by insecticide treatments; however, with the increase of BC farming systems, $N$. viridula has become a very destructive pest. This is especially true when high populations are distributed throughout the greenhouse. Egg parasitoids can be used for the BC of this bug, although their use is not common (Table 1.1) (Catalán and Verdú, 2005). 
General Introduction

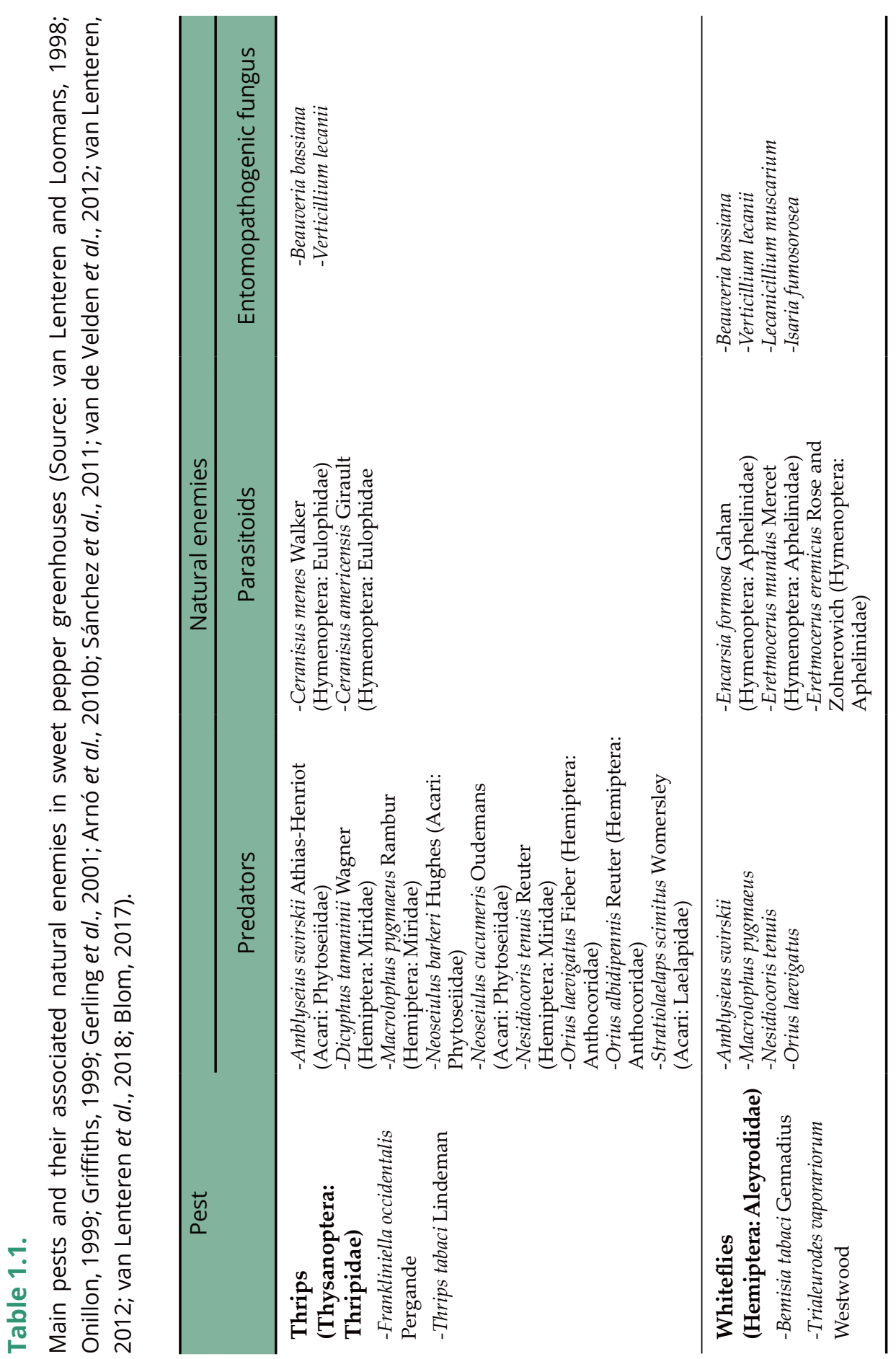


Sarra Bouagga

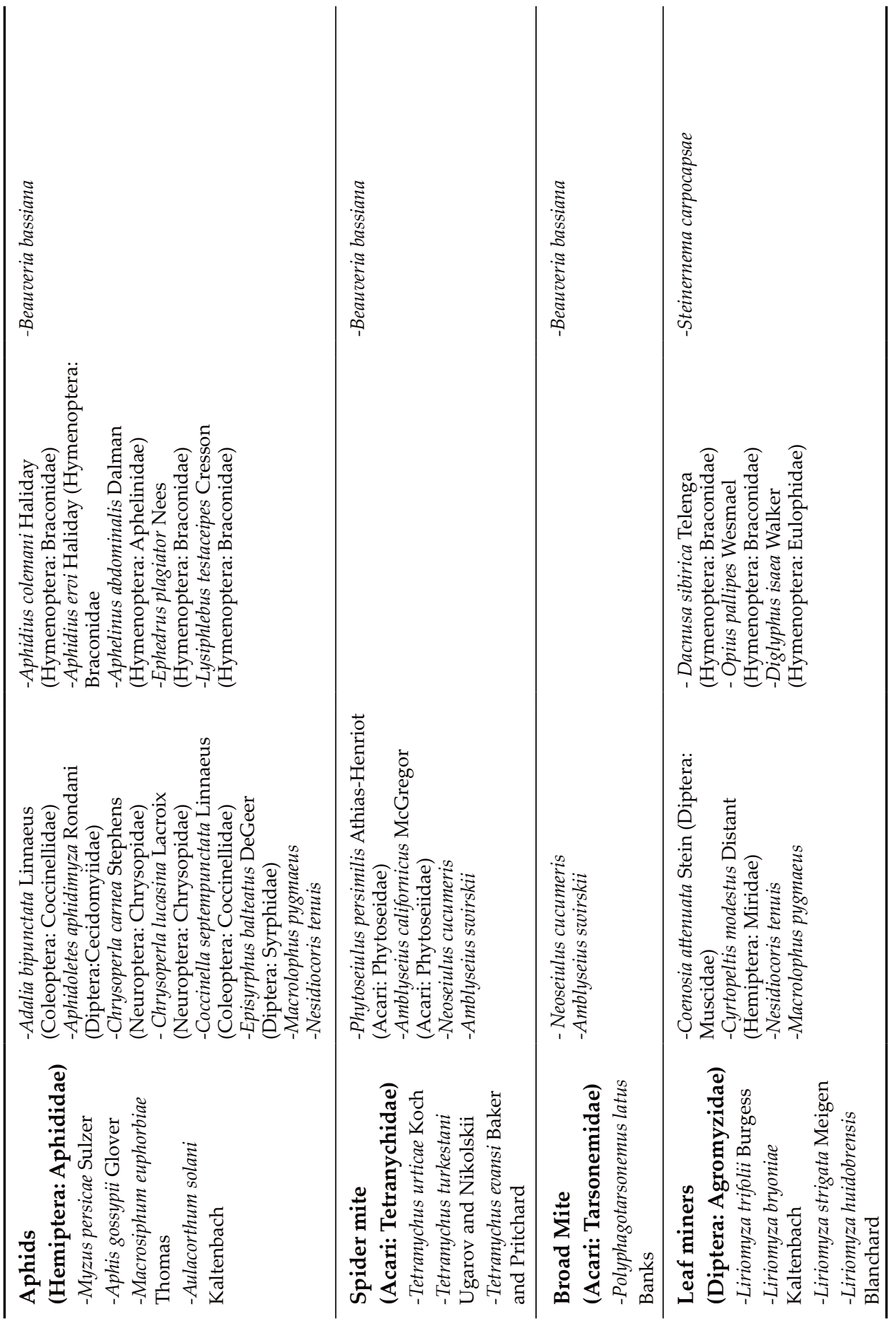




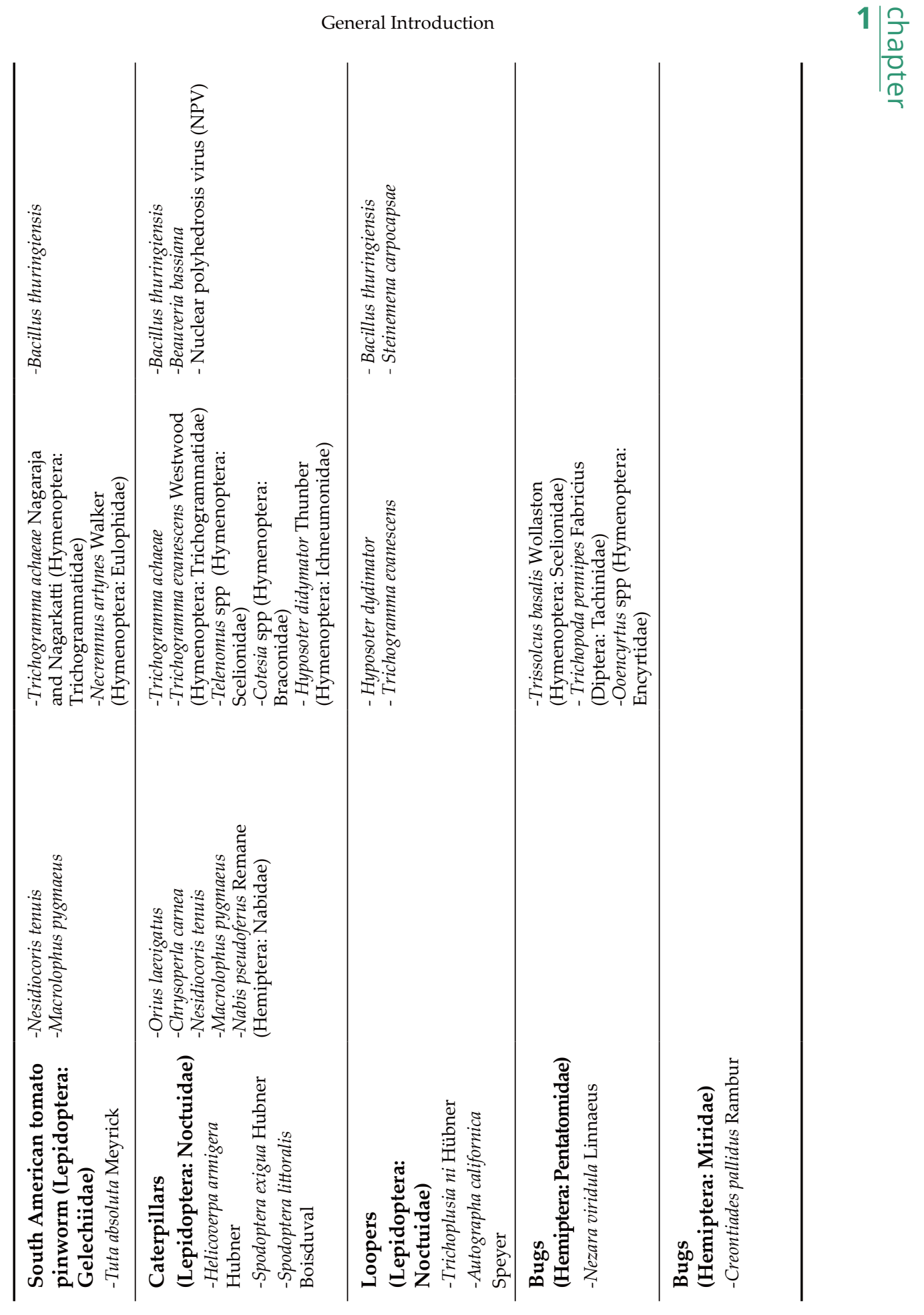




\subsubsection{Current status of biological control in sweet pepper}

In Europe throughout the last ten years pest control in protected crops has shown noticeable improvement through the replacement of chemical control with BC (Heimpel and Miles, 2017; van Lenteren et al, 2018; Barratt et al., 2018). The green revolution, the international market demand and the restrictive legislation minimising the number of authorised chemical products have resulted in a quick shift from chemical insecticide dependency to the implementation of IPM programs based on BC for various horticultural crops. In less than 10 years the total greenhouse area grew from 1,400 hectares biologically controlled in 2006 to 26,372 ha in 2014 (Sanchez et al., 2014).

One of the most impressive success stories of BC occurred in the sweet pepper crop in Southern Spain (Blom, 2017). Since the end of the last century, attempts to implement BC of sweet pepper started in Campo de Cartagena region. In contrast, in the Almeria region, the leader of sweet pepper production in Spain, BC implementation was delayed mainly due to pest pressure during the summer planting period. However, nowadays, this delay has been overcome and sweet pepper areas under BC program in Almeria have increased from a mere 200 ha in the 2005-2006 season to about 7,500 ha in 2008-2009. Currently the area has surpassed the 10,000 ha in 2015-2016 (Fig.1.2) (Calvo et al., 2015; Blom, 2017).

In greenhouse sweet pepper, $\mathrm{BC}$ programs are now based on the release of generalist predators, the predatory mite Amblyseius swirskii Athias-Henriot (Acari: Phytoseiidae) together with the minute pirate bug Orius laevigatus Fieber (Hemiptera: Anthocoridae). Both predators are achieving great success in managing the key sweet pepper pests; $B$. tabaci and F. occidentalis (Calvo et al., 2015). 

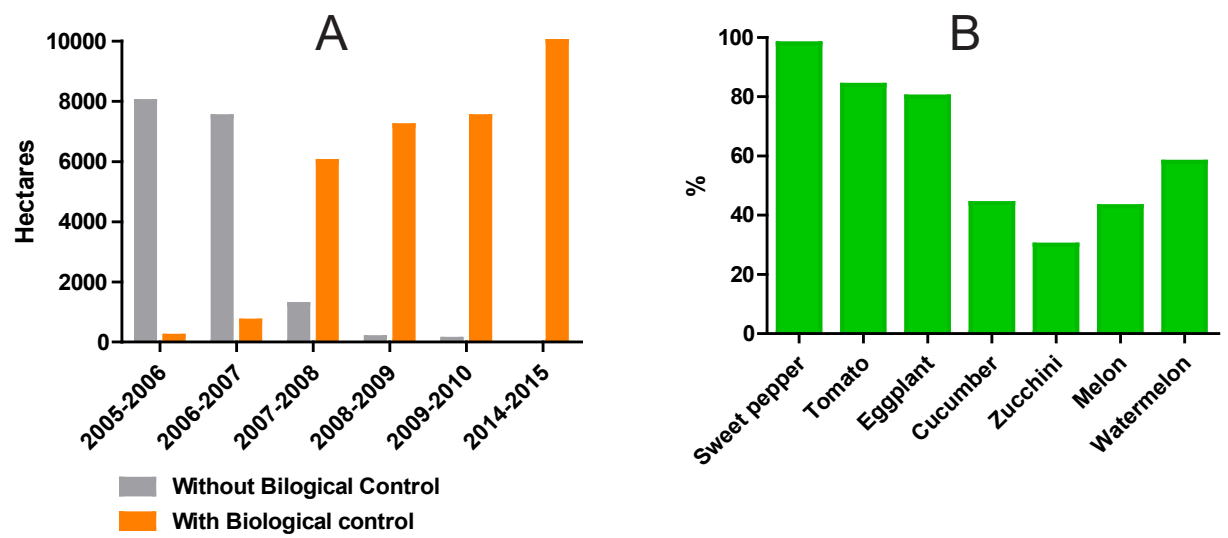

Figure 1.2.

Sweet pepper area (ha) under BC (A); Percentage of farms with BC (B) (Almería region), (Blom, 2017; Calvo et al., 2015).

\subsubsection{Amblyseius swirskii}

The predatory mite $A$. swirskii (Fig 1.3) originated in the MediterraneanMiddle east area. Since 2005, it has been reared and commercially available as a BC agent for whiteflies and thrips in different crops (Nomikou et al., 2001, 2002; Belda and Calvo, 2006; Messelink et al., 2008; Calvo et al., 2011, 2015). The ability of $A$. swirskii to establish even before the appearance of the pest, owing to its capability of feeding on alternative food sources, enhances its efficiency as a BC agent. Among these alternative food sources of pollen, nectar, small insects and mites, such as T. urticae and P. latus, other non-prey food, including eggs of the Mediterranean flour moth Ephestia kuehniella Zeller (Lepidoptera: Pyralidae) or decapsulated dry cysts of the brine shrimp Artemia franciscana Kellogg (Anostraca: Artemiidae) have been reported (Nomikou et al., 2002; van Houten et al., 2005a, 2005b; Messelink et al., 2006, Messelink et al., 2010, van Maanen et al., 2010; Nguyen et al., 2013; Calvo et al., 2015). 


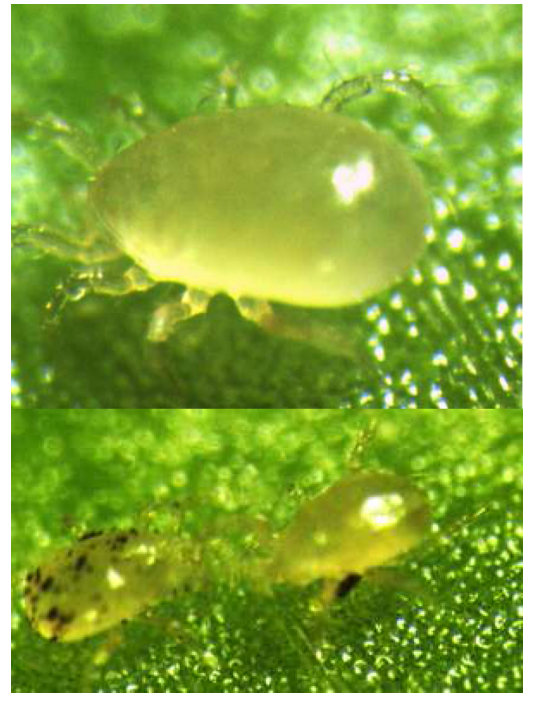

Figure 1.3.

Adut Amblyseius swirskii.

In Spain during the 2012-2013 season total greenhouse areas under BC using A. swirskii exceeded the 18,000 ha (Calvo et al., 2015). As mentioned before, releases of this predaceous mite have been extensively used with remarkable success for the control of $B$. tabaci in sweet pepper (Calvo et al., 2008, 2009a, 2012a). A rate of 50-75 A. swirskii/m² combined with the releases of the parasitic wasp Eretmocerus mundus Mercet (Hymenoptera: Aphelinidae) provided excellent suppression of $B$. tabaci in sweet pepper greenhouses (Calvo et al., 2009a).

Amblyseius swirskii mainly preys on eggs and crawlers (Nomikou et al., 2001, 2004), whereas E. mundus parasitizes nymphal instars of B. tabaci but especially the second and third (Urbaneja and Stansly, 2004). Thus, released together, both predators provided satisfactory results. Amblyseius swirskii is also an effective predator of thrips in sweet pepper (Belda and Calvo, 2006; Calvo et al., 2012a) and other crops. Previous laboratory results on cucumber leaves showed $A$. swirskii to be 
more effective than Neoseiulus cucumeris Oudemans (Acari: Phytoseiidae) which had been previously used to control this pest (Messelink et al., 2006). Later, Messelink et al. (2008) observed that A. swirskii was also able to control the greenhouse whitefly T. vaporariorum in cucumber in the presence of F. occidentalis. More confirmation in cucumber crops, were observed by Calvo et al. (2011) who, at a release rate of 50-75 A. swirskii $/ \mathrm{m}^{2}$, adequately managed F. occidentalis and B. tabaci both alone and simultaneously. Accordingly to the above mentioned results, the adapted release of $A$. swirskii significantly reduced the infestation of B. tabaci and F. occidentalis. However, in the case of sweet peppers, thrips was not adequately controlled in flowers enough to mitigate the risk of (TSWV) infections (Lacasa and Contreras, 1993; Belda and Calvo, 2006). Therefore, combining the phytoseiid with the anthocorid bug, O. laevigatus, satisfies the requirements of the BC of sweet pepper pests (Weintraub et al., 2011; Calvo et al., 2012a).

\subsubsection{Orius laevigatus}

The generalist anthocorid predator O. laevigatus (Fig.1.4), is a western Palaearctic species, widespread along Mediterranean and Atlantic coasts. This anthocorid has various characteristics which make it a promising agent of BC. For example, O. laevigatus lacks expressed diapauses, presents high fecundity, a long life span and is polyphagous (Tommasini and Nicoli, 1996). 


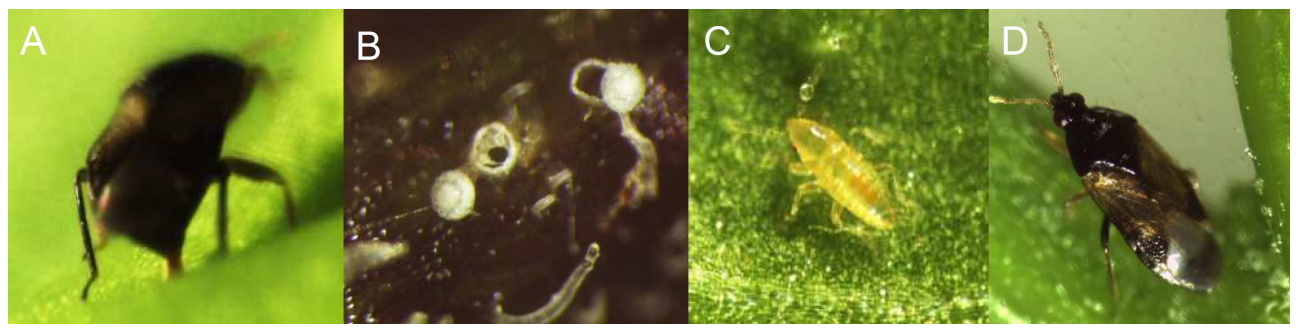

Figure 1.4.

Female Orius laevigatus laying eggs (A), Eggs of O. laevigatus inserted in sweet pepper stem (B), First instar nymph (N1) (C), Adult (D).

Orius laevigatus is considered to be key predator in the BC of thrips, preying on both larvae and adults. It can also be effective against B. tabaci (Chambers et al., 1993; Dissevelt et al., 1995; Frescata and Mexia, 1996; Hamdan and Abu-Awad, 2007, 2008). In addition, O. laevigatus can consume other arthropod pests such as aphids and mites (Alvarado et al., 1997; Venzon et al., 2002). Nowadays, this predator is produced by many commercial insectaries (since 1993) and largely used in IPM programs. The number of Orius spp. released to control thrips in greenhouse varies in published literature, ranging from 0.4 to 2 individuals per plant (Chambers et al., 1993; Tavella et al., 1996; van Schelt, 1999; Sánchez and Lacasa, 2002; Bosco et al., 2008). The best time for the release of O. laevigatus on the pepper crop is about one month after transplanting, when the plants are flowering and fully grown (Bosco et al., 2008).

Like many other anthocorids, O. laevigatus is primarily predaceous; however, this predator is also able to exploit plant resources including pollen and plant juices (Frescata and Mexia, 1996; Cocuzza et al., 1997; Armer et al., 1998; Lattin, 1999; Shakya et al., 2009). Plants fulfil several roles throughout the life cycle of Orius bugs. They represent an egg-laying substrate but also serve as a source of moisture and supplementary nutrients (Coll, 1996; Lattin, 
1999). Using radio labelling experiments, Armer et al. (1998) observed adults

of O. insidiosus Say (Hemiptera: Anthocoridae) feeding on the mesophyll of soya bean plants by ingesting small amounts of sugars, starches and amino acids. It can also obtain water from xylem of the same plant. Besides the feeding behaviour of adults, Lundgren et al. (2008) reported that neonate O. insidiosus were able to feed on nutritious phloem, allowing them to survive on plant materials for several days. This phytophagous characteristic of anthocorid bugs results in important behaviour which helps predator establishment and population maintenance during the absence of proteinrich food. This alternative feeding, thus, maintains the predator on the crop. Therefore, plant feeding by Orius bugs is an interesting aspect which still has yet only been slightly explored. Plant feeding is generally associated with chemical and physiological interactions to fine-tune the predatory attack (section 1.3). Therefore, we hypothesized that plant feeding could result in physiological changes on sweet pepper plants (such as induction of plant defences) which might constitute an additive effect for pest management. Therefore, we focused Chapter 2 of this thesis on studying the feeding behaviour of this predator and its ability to induce plant defence in sweet pepper.

\subsubsection{Gaps in the biological control of aphids}

Despite the success of the current BC program in sweet peppers, good management of aphids on the sweet pepper crop is still hard to achieve (Blom, 2008; Bloemhard and Ramakers, 2008). Aphid populations can develop so quickly that the introductions of natural enemies are often unsuccessful (Rabasse and van Steenis, 1999). Habitually, aphids 
are controlled through multiple releases of natural enemies (Blom, 2008). The parasitoid Aphidius colemani Viereck (Hymenoptera: Braconidae), the specialist predatory midge Aphidoletes aphidimyza Rondani (Diptera: Cecidomyiidae) (Blümel, 2004) and other generalist predators, such as those of the chrysopidae, syrphidae, and coccinellids (Pineda and Marcos-García, 2008; Messelink et al., 2011b, 2013) are regularly used for managing aphids in sweet pepper. Myzus persicae and A. gossypii can be sometimes controlled with the use of banker plants infested with the cereal aphid Rhopalosiphum padi Linnaeus (Hemiptera: Aphidiidae) (Huang et al., 2011). Introductions of natural enemies are done on these banker plants so their populations increase considerably before aphid move to the crop (Calvo and Urbaneja, 2004b). The specialised predatory midge is mainly released for controlling high densities of aphids. The generalist predators (chrysopidae, syrphidae, or coccinellids) are also frequently released against the two aphid species. However, their failure to establish in the absence of aphids lowers the efficacy of their use (Messelink et al., 2011b; Messelink et al., 2013). Overall, these augmentative releases are not always sufficiently effective, not only because the release of parasitoids can be disrupted by the abundance of hyperparasitoids in south eastern Spain (Belliure et al., 2008, Sánchez et al., 2011), but also because the final cost of the biocontrol program in sweet pepper is considerably elevated (Messelink et al., 2011a). Additionally, the occurrence of intraguild predation (IGP) between generalist thrips and whitefly predators with specialist aphid natural enemies has complicated the management of aphids even more in sweet pepper (Messelink et al., 2012). According to Messelink et al. (2011b) the predatory mite A. swirskii used for managing thrips and whiteflies in sweet pepper can seriously disrupt the $\mathrm{BC}$ of aphids by preying on the eggs of the predatory midges. 
Christensen et al., (2002) also observed how Orius spp. bugs can prey on eggs and larvae of A. aphidimyza and, therefore, act as an intraguild predator (Alvarado et al., 1997).

Thus, the BC control of aphids in sweet pepper requires improvement. Facing this need, several reports recently highlighted the positive role of zoophytophagous mirid predators in managing aphids in sweet pepper and other crops (Perdikis and Lykouressis, 2004, Messelink et al., 2011a; Messelink et al., 2015; Pérez-Hedo and Urbaneja, 2015; De Backer et al., 2015). Hence, according to these previous encouraging results we focused chapters $\mathbf{4}$ and $\mathbf{5}$ of this thesis, on studying the efficiency of predatory mirids in managing sweet pepper pests including thrips, whitefly and aphid.

\subsection{Zoophytophagous predators}

Increased attention has recently been directed at the role of generalist omnivores as regulators of insect herbivore populations in agricultural ecosystems. Zoophytophagous predators are a special case of omnivory defined as predators that feed on prey and plant during the same developmental stage (Wheeler, 2001). Their ability to switch between zoophagy and phytophagy enhanced their establishment and sustained population densities. In turn the population was capable of controlling incipient pest outbreaks early in the season following the initial colonization of the crop by pests or later in the season following a period of pest scarcity (Sánchez and Lacasa, 2008; Castañé et al., 2011). In this group, predatory mirid bugs (Hemiptera: Miridae) such as Nesidiocoris tenuis Reuter (Fig.1.5) and Macrolophus pygmaeus Rambur (Fig.1.6) are important predators of several agriculture pests. 


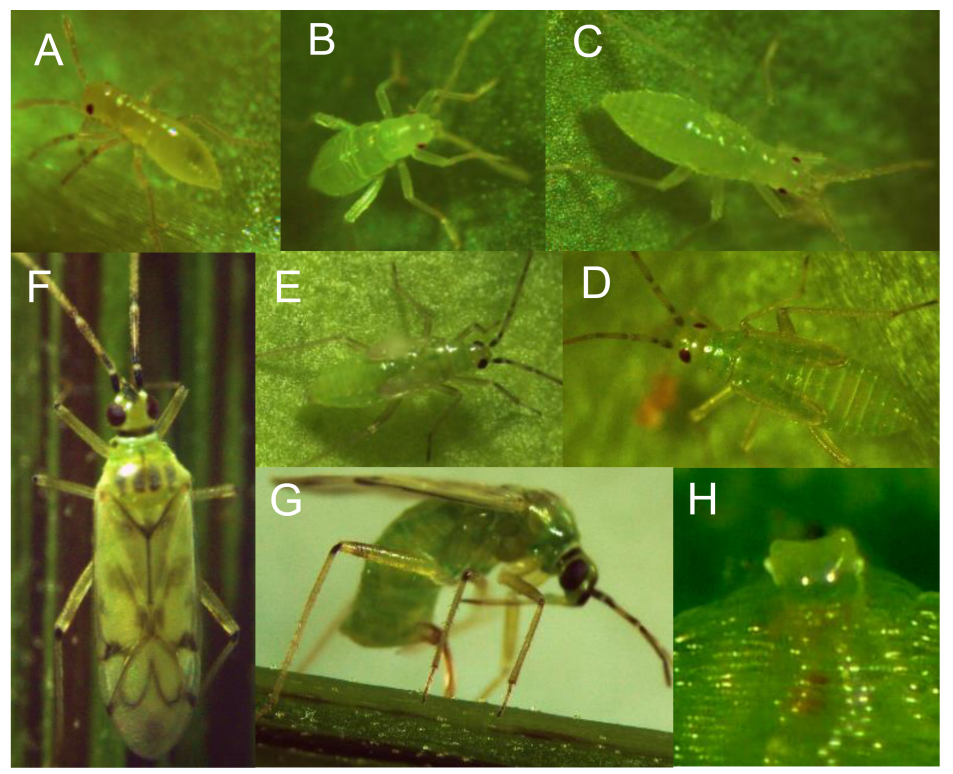

Figure 1.5.

Developmental stages of Nesidiocoris tenuis, $1^{\text {st }}$ instar (N1) (A), $2^{\text {nd }}$ instar (N2) (B), $3^{\text {rd }}$ instar (N3) (C), $4^{\text {th }}$ instar (N4) (D), $5^{\text {th }}$ instar (N5) (E), Adult (F), Female laying eggs (G), Egg of $N$. tenuis inserted in sweet pepper stem $(\mathrm{H})$.

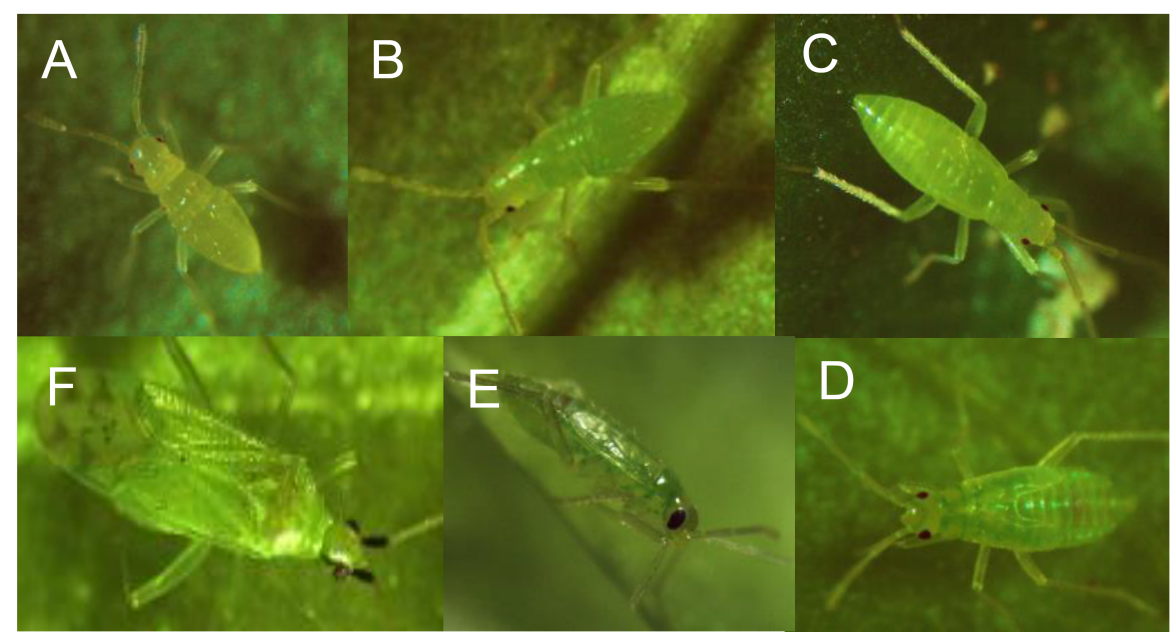

Figure 1.6.

Developmental stages of Macrolophus pygmaeus, $1^{\text {st }}$ instar (N1) (A), $2^{\text {nd }}$ instar (N2) (B), $3^{\text {rd }}$ instar (N3) (C), $4^{\text {th }}$ instar (N4) (D), $5^{\text {th }}$ instar (N5) (E), Adult (F). 


\subsubsection{Mirids as biocontrol agents}

Currently, N. tenuis and M. pygmaeus are widely used as BC agents to manage some major greenhouse pests including, whiteflies, thrips, leafhoppers, leaf miners, spider mites and Lepidoptera species in greenhouses (Perdikis and Lykouressis, 2002; Calvo et al., 2009a; van Lentereen, 2012; Urbaenja et al., 2012; Pérez-Hedo and Urbaneja, 2015). Macrolophus pygmaeus has been commercially available since 1994 and its use as a generalist predator has steadily increased in European tomato greenhouses with a medium commercial value (10.000-100.000 individuals sold per week). However, the use of $N$. tenuis started in 2003 with a large commercial value (hundreds of thousands to millions of individuals sold per week) (Malausa and Trottin-Caudal, 1996; van Lenteren, 2003, 2012; Cock et al., 2010). Both predators feed by inserting the stylet and sucking out the body contents of the prey. Two distinctive strategies may be adopted for the use of these predators as BC agents depending on the crop and pest pressure:

- Conservation: Spontaneous appearance.

- Augmentation: Either an inoculative release after transplantation or a nursery release on seedlings.

Conservation BC is based on the fact that both $N$. tenuis and $M$. pygmaeus are two endemic natural enemies that appear spontaneously in several crops of the Mediterranean Basin (Alómar et al., 2002; Sánchez et al., 2003, Calvo and Urbaneja, 2003, Stansly et al., 2004, Urbaneja et al., 2005). Their ability to colonize alternative plants 
as mentioned below (Section 1.2.2) (Table 1.2) allows the conservation of both predators and then their establishment during the crop season. However, the appearance of mirid predators in the greenhouses can be too late to guarantee pest control (Perdikis et al., 2011). Therefore, conservation BC should be directed to identify which noncrop host plants support high numbers of these predators early in the season (Gabarra et al., 2004). For example, in tomato unheated greenhouses, Arnó et al. (2000) showed tobacco plants to serve as a refuge for $M$. pygmaeus during winter, enhancing the timely and efficient colonization of the following spring tomato crop. Overall, the successful implementation of conservative BC, requires future research efforts to focus on the investigation of various aspects, such as, the correct identification of the mirid species and the non-crop plant, the evaluation of the dispersal ability on the non-crop plant and guarantee the early colonization of the target crop (Perdikis et al., 2011).

As mentioned above, both $N$. tenuis and M. pygmaeus are mass-reared and commercially available to release in augmentative BC programs against different pest (Gerling et al., 2001, Calvo and Urbaneja, 2004a, Alómar et al., 2002; Calvo et al., 2009a, Urbaneja et al., 2012). Augmentative BC is based on the inoculation of the crop with the predator before or after pest outbreaks. In greenhouse tomato, inoculation with $N$. tenuis at a rate of 1-2 individual(s)/ $/ \mathrm{m}^{2}$, was a common practice usually performed 4-5 weeks after transplantation which effectively controlled whiteflies. This strategy allowed a reduction of $81 \%-96 \%$ in B. tabaci abundance (Calvo et al., 2009b). The same management practise achieved great success against T. absoluta on tomato crops. The release of 1-2 M. pygmaeus or $N$. tenuis adult(s) per $\mathrm{m}^{2}$ reduced leaflet and fruit 
infestation of T. absoluta by up to $97 \%$ and $100 \%$ with N. tenuis and $76 \%$

and 56\% with M. pygmaeus, respectively (Mollá et al., 2009). On infested sweet pepper plants, 1 reproductive couple of $N$. tenuis, M. pygmaeus and/or Dicyphus maroccanus Wagner (Hemiptera: Miridae) per plant, successfully reduced $M$. persicae infestation nearly $100 \%$, for both predators (Pérez-Hedo and Urbaneja, 2015). However, the success of this latter strategy requires a certain predator density in the crop (Calvo et al., 2009a). The problem is that reaching a sufficient mirid population level takes 5-8 weeks, and in many occasions pests could appear earlier in the crop which could result in serious damage. When established, the infestation may not be able to be solved by predators (Mollá et al., 2011; Urbaneja et al., 2012). Another weak point in this strategy in late crop cycles without heating, is the mirid reproduction rate is not high enough to reach the desired population levels (Urbaneja et al., 2012). Therefore, the nursery release of predatory mirids, before transplanting, could be an alternative strategy, that shortens the establishment period and improves predator distribution in the crop. This technique was used initially with M. pygmaeus (Lenfant et al., 2000; Trottin-Caudal et al., 2012). Adult predators were released on the seedlings, and initially fed eggs of the fastidious prey E. kuehniella. The eggs laid by M. pygmaeus hatch very soon after transplantation, allowing population growth to start earlier (Trottin-Caudal et al., 2012). The preplant release rate of $N$. tenuis at $0.5-1 \mathrm{~N}$. tenuis/plant, satisfactorily manage $B$. tabaci and T. absoluta populations, without evident damages caused by the phytophagy of $N$. tenuis. In this strategy, E. kuehniella eggs are used as substitute prey to enable predator establishment and to increase its abundance prior to pest outbreaks, which might accelerate the response 
of the predator and considerably reduce pest incidence (Calvo et al., 2012a, 2012b). The fact that $N$. tenuis females need to mate periodically in order to maintain a sufficient sperm supply to fertilize their eggs (Franco et al., 2011) and predator populations are more concentrated when released before planting are well known. This might result in a higher encounter rate, giving more opportunities for adults to mate and to fertilize maturing eggs, which would increase the number of progeny, and therefore predator abundance in the subsequent generation. Also, fecundity, longevity and preimaginal survival of $N$. tenuis were observed to increase when the predator was fed E. kuehniella eggs (Urbaneja et al., 2005). Thus, addition of E. kuehniella eggs during the first weeks after release, a normal procedure in use, should also have the positive effect of enhancing establishment of $N$. tenuis and M. pygmaeus. The prior release of $M$. pygmaeus with a weekly application of supplemented food (E. kuehniella eggs + decapsulated cysts of the brine shrimp A.franciscana), was reported to increase the population of the predator to very high densities which favoured the control of M. persicae (Messelink et al., 2011a; Messelink et al., 2015). Five weeks after predator release the aphid density remained below 1 aphid per plant, while it exceeded the 1000 aphids per plant in untreated greenhouse plots. These results again suggest that a high predator/prey ratio is needed to achieve sufficient control. Aphids multiply extremely fast by viviparous parthenogenetic reproduction, resulting in relative growth rates on sweet pepper of 0.36 females per female per day (Dewhirst et al., 2012). Aphids will quickly outnumber mirid predatory bugs which have a relatively low reproduction rate (Perdikis and Lykouressis, 2004). Thus, the numerical response of the predators is far too slow to control aphids. 
Preventive releases of predators can solve this problem, thus, prior to pest establishment releases can result in relatively high initial predator/ pest ratios which are enough to control aphids. Therefore, inoculative release of predatory mirids prior to planting is the best strategy for their successful use as BC agents. This strategy can, however, have some negative sides effects mainly related to tomato crops, but perhaps, not for sweet pepper. In any case, the monitoring of the predator population density is mandatory to avoid any possible damages induced by the plant feeding behaviour of mirid predators.

\subsubsection{Phytophagous behaviour of mirid predators}

Thanks to their adaptation to living on plant surfaces covered with non-glandular and/or glandular trichomes (Voigt et al., 2007; Voigt and Gorb, 2010), N. tenuis and M. pygmaeus have been reported on several plants species including wild and cultivated host plants (Table 1.2). Macrolophus pygmaeus offers the advantage of obtaining carbohydrates and other nutrients by feeding directly on plant tissues making it independent of nectar and prey availability (Hansen et al., 1999; Perdikis and Lykouressis, 2000, 2002; Portillo et al., 2012). It was reported to survive 3.67 days without any food and 25.67 days by feeding exclusively on eggplant young leaves (Mohd Rasdi et al., 2009). Immature development by $M$. pygmaeus was observed to be completed only when tomato, eggplant, cucumber, pepper, green bean, broad bean or melon were available (Perdikis and Lykouressis, 1999, 2000; Lykouressis et al., 2001). In the absence of prey, the order of suitability for M. pygmaeus longevity, fecundity, and population increase is eggplant 
then tomato and finally sweet pepper. The lower suitability of pepper sap compared to that of eggplant or tomato may positively affect the predation rate of $M$. pygmaeus on pepper because omnivorous predatory bugs may have a stronger tendency to search for and feed on prey on low quality host plants rather than on high-quality plants (Abrams, 1987). Nymphs with access to a water source (moistened cotton), can successfully reach adulthood when fed exclusively bee pollen and on stamens cut from fully bloomed flowers of the weed Ecballium elaterium L. (Cucurbitaceae), without any other plant or prey material (Perdikis and Lykouressis, 2000). The same authors also showed when bee pollen pellets were added to a diet of eggplant leaves, the development period of $M$. pygmaeus was significantly shortened and completed within a period similar to that when it was fed on eggplant leaves with the aphid prey, M. persicae. In addition to cultivated plants, M. pygmaeus was reported to complete development on Solanum nigrum L. (Solanaceae) without prey and can also reproduce when infested by its main native aphid pest (Lykouressis et al., 2008). Whereas, plant feeding seems important for M. pygmaeus, its performance as predator depends on the plant food. However, its best development was always observed when it fed on prey (Lykouressis et al., 2001, 2008; Perdikis and Lykouressis, 2004; Ingegno et al., 2011). On the contrary, Lykouressis et al. (2014) and Maselou et al. (2014) supported the idea that exclude a negative effect between plant feeding and predator functional response. In fact, the predation rate of $M$. pygmaeus did not differ on leaves of four host plants (tomato, pepper, eggplant and black nightshade) of varying suitability for development and/or reproduction. 
The range of plant species on which $N$. tenuis has been recorded is large (Table 1.2). This predator can feed on all the aerial parts of tomato plants but has a strong preference for the three uppermost leaves and the apical bud, which is where up to $80 \%$ of the predator population is found (El-Dessouki et al., 1976; Castañé et al., 2011). Contrarily to $M$. pygmaeus, a diet exclusively derived from vegetable substrate (tomato, sweet pepper and eggplant) is insufficient for the development of $N$. tenuis (Urbaneja et al., 2005). Although, tomato seems to favour its development compared to eggplant and pepper, a supplemental food (E. kuehniella eggs) is mandatory for $N$. tenuis to complete its development, when prey are absent. According to Urbaneja et al. (2005), sweet pepper was the least suitable host plant, allowing only $10 \%$ of the nymphs to survive through the first instar, survivorship was the lowest, and nymphal development time was the longest. In another series of experiments studying the functional response of $N$. tenuis on various host plants, tomato was also the most suitable plant for predation activity on T. vaporariorum (Hassanpour et al., 2016), when compared to cucumber and eggplant. Solanum indicum L. (Solanaceae) is also reported to be a suitable host plant for $N$. tenuis development and oviposition (Biondi et al., 2016). Sesame is very rich in protein, carbohydrates, and minerals so it probably provides the protein fraction needed for $N$. tenuis to continue its development (Mbaebie et al., 2010). 


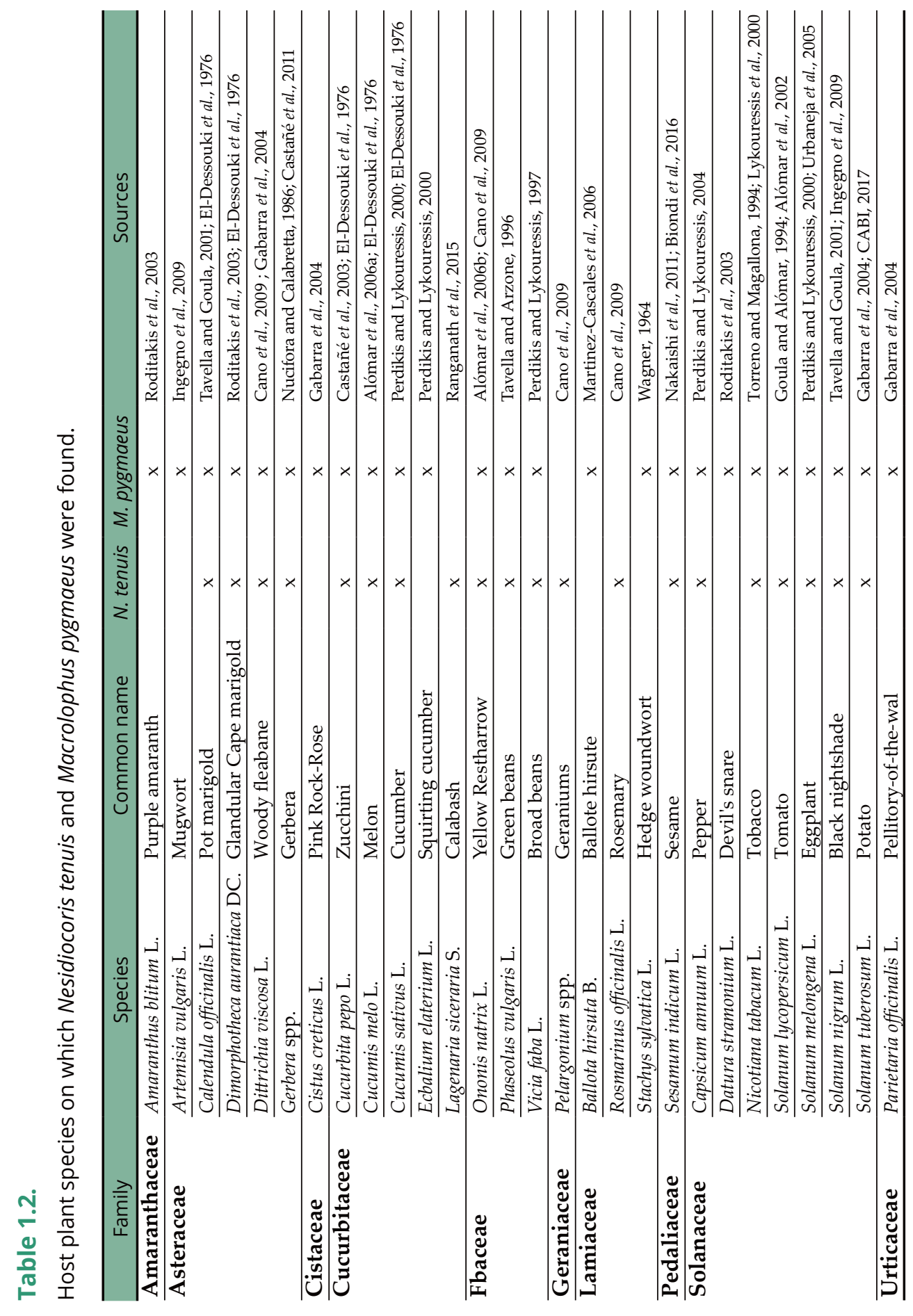




\subsubsection{Plant damage by mirid predators}

Phytophagous behaviour of some mirid predators have been reported to induce plant damage which affects growing plant tissues, stems, leaves and fruit (El-Dessouki et al., 1976; Castañé et al., 2011). To date, no evidence has been found identifying the exact vascular tissue on which $N$. tenuis and M. pygmaeus insert their stylet; however, according to Wheeler (2001), mirid predators are classified as phloem feeders of stem and petioles. During the seventies, the microscopic examination of tomato parts damaged by $N$. tenuis through disections of stem and petiole, illustrated obvious destruction of tissues (El-Dessouki et al., 1976). Cell walls were found to be broken in most of the cells, thus, indicating that $N$. tenuis sucks out the intracellular juice with its stylet. The predator destroys the epidermis cell, then it rolls its stylet inside the cortex tissue and extends it to break up the endodermal layer and some of the xylem, phloem and pith cells (El-Dessouki et al., 1976).

Therefore, plant feeding by $N$. tenuis was reported to cause plant damage, thus, this predator was habitually considered to be a pest in different parts of the World. In tomatoes, repetitive insertion of the stylet on vascular tissue induces necrotic rings on stems, leaves or flower petioles that may reduce plant vigour or cause flower abortion (El-Dessouki et al., 1976). Recently, Sánchez et al. (2016), observed feeding activity of N. tenuis to produce a significant variation in the concentration and distribution of assimilates (i.e. amino acids and sugars) in tomato stems. This chemical change in tomato was observed to inhibit the transfer of nutrients in the phloem and negatively affect the fitness of nymphs that develop on those parts of the plant (Sánchez et al., 2016). The intensity of injuries on tomato crops is proportional to the availability of the prey (Arnó et al., 2010a; Calvo 
et al., 2009b). Describing the damages produced by N. tenuis on greenhouse tomato, Sánchez (2008) found the highest damage incidence (5 necrotic rings on the upper $20 \mathrm{~cm}$ of the plant shoot) was produced when about $3 \mathrm{~N}$. tenuis individuals per leaf occurred in a period when the number of the whitefly population was low. Thus, this predator is following the feeding model 1 proposed by Gillespie and McGregor (2000). According to this model, a decrease in the availability of prey increases the phytophagy, which would only occur when the prey is scarce and the predator is forced to change his feeding habits. Nevertheless, according to Calvo et al. (2012b), N. tenuis can also follow the feeding model 2, which means phytophagy increases when zoophagy increases (Gillespie and McGregor, 2000). These authors observed necrotic rings on tomato plants when the predator had abundant E. kuehniella eggs and whitefly nymphs, they hypothesized that $N$. tenuis tended to increase its feeding behaviour in the presence of the prey due to the necessity of obtaining water for their extra-oral digestion (Calvo et al., 2012b). Hence, as concluded by Castañé et al. (2011), these models are appropriate for explaining the behaviour of individual predators and are not mutually exclusive: individuals could behave according to one model or another depending on crop circumstances and plant feeding is essential rather than facultative. Overall, phytophagous behaviour of $N$. tenuis seems to affect the final number of fruit per plant and may lead to some economic loss (Sánchez, 2009; Arnó et al., 2010a). However, according to Sánchez and Lacasa (2008), such loses might be compensated by the greater weight of the remaining fruit. Indeed, these authors did not observe yield when population levels of $N$. tenuis ranged from 0.53 to 35.2 individuals per plant.

In contrast to $N$. tenuis, M. pygmaeus has been generally considered as safe and plant damages have been observed only with very high predator 
densities on tomato, zucchini, and gerbera under experimental conditions, but no such damage has been observed under cropping conditions (Castañé et al., 2011). With high predator densities and low prey availability, M. pygmaeus was observed to cause dimples, pits and distortion on fruit under laboratory conditions (Castañé et al., 2011). In a field survey conducted in the UK Sampson and Jacobson (1999) reported distorted tomato leaf growth, necrotic spots on leaves, scars on fruit and fruit drop with high predator densities (50-300 individuals per plant) and very low prey abundance. Recently, Moerkens et al. (2016, 2017), reported that M. pygmaeus can cause economic feeding damage on tomato fruit at high population densities and severity of crop damage is significantly enhanced when plants are infected with pepino mosaic virus PepMV. This virus causes, from a few dimples to yellowish discoloration and deformed fruits. The same authors suggest the minimum economic density threshold to be estimated at $0.32 \mathrm{M}$. pygmaeus per leaf.

In general, crop damage is often the result of complex interactions between the morphological, physiological and behavioural traits of the natural enemy, plant, crop type, and certain environmental factors. Castañéet al. (2011) examined scanning electron microscopy images of the mandibular and maxillary stylets of D. tamaninii Wagner (Hemiptera: Miridae), N. tenuis and M. pygmaeus with from which, they concluded great similarly in their shape. The mandibular stylets of all three species had between 10 and 12 teeth and their maxillary stylets had at least 4 strongly curved teeth. Therefore, the differences observed in the types and intensities of the damage produced by $N$. tenuis and M. pygmaeus does not seem be directly related with the morphologies of their respective stylet bundles. Indeed, damages are not primarily produced mechanically but are the result of a chemical process 
by which the affected cells are killed by salivary enzymes (El-Dessouki et al., 1976; Halitschke et al., 2011).

Whereas, the relation between mirids and plants seems to be profound (as described above); studies on plant defensive response to the phytophagous behaviour of these groups of predators have been rare. Recently, the phytophagous behaviour of the mirid predators ( $N$. tenuis, M. pygmaeus and D. maroccanus) and also the oviposition behaviour of the anthocorid bug $O$. laevigatus was investigated and provides clear evidence of inducing plant responses as strictly herbivores do in tomato plants (De Puysseleyr et al., 2011; Pérez-Hedo et al., 2015a, 2015b, Pappas et al., 2015, 2016; Naselli et al., 2016). These finding might provide an explanation for the great success recently achieved by the use of mirids as key biocontrol agents for tomato crop (Pérez-Hedo et al., 2017a).

\subsection{Plant defence mechanisms}

In nature plants are in continuous interaction with the ecosystem. Plants avoid unfavourable conditions thanks to their defence mechanisms (Maekawa et al., 2011). The occurrence of abiotic stress (i.e. drought, flooding, salinity, extreme temperatures or intense light), enhance plants to develop several mechanisms to protect themselves from disturbance involving the activation of different biochemical pathways leading to the production of either defensive compounds or morphological changes (Bartels and Souer, 2004; Krishna, 2004). Mechanical damages also induce stress responses and the activation of plant defence mechanisms. However, plant tissue damage can be caused by either noticeable or invisible lesions. Some lesions, with small diameters are not detected visually; nonetheless, they might contribute 
to the activation of wound-responses to prevent further damage (Pullin and Gilbert, 1989). Besides the described stressful conditions, plants are also faced with a plethora of attackers including herbivorous arthropods and plant pathogens, where insects are among the most important invaders. To survive, plants have developed a stunning array of structural, chemical, and protein-based defences designed to detect invading organisms and stop them before they are able to cause extensive damage (Karban and Baldwin, 1997; Walling, 2000; Heil and Ton, 2008; Ponzio et al., 2013; Kessler, 2017). Plant defence strategies can be generalized with two categories: constitutive defences, which include physical and chemical barriers that exist even before insect attack, and inducible defences, which are activated after detection of insect attack, therefore minimizing the metabolic cost of defence for the plant (Dicke and van Poecke, 2002; Agrawal and Heil, 2012). Two types of inducible defences have been observed in plants: direct defences and indirect defences (Fig. 1.7).

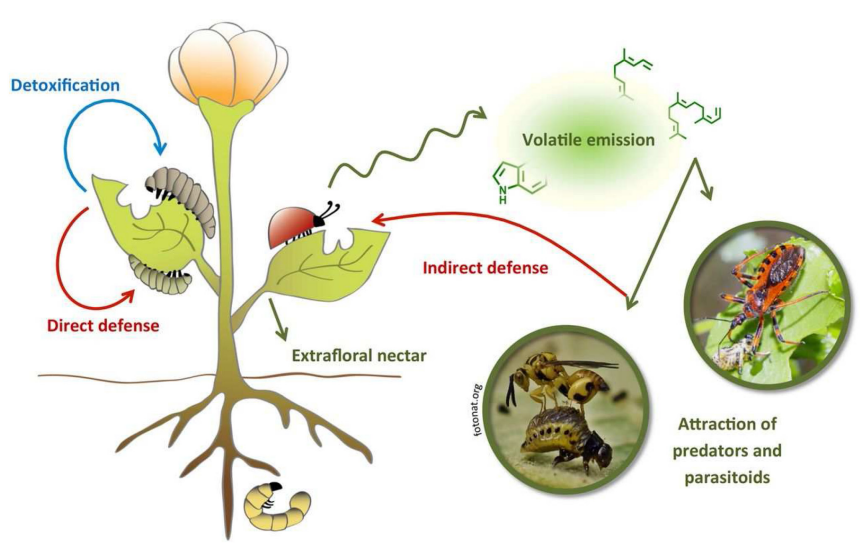

Figure 1.7.

Model of plant-insect herbivore interactions and associated chemical defence mechanisms. Feeding insects above and below ground face direct chemicals defence responses. Indirect defences are represented by extrafloral nectar that can attract ants or natural enemies to defend the plant by the emission of volatile organic compounds (Mithöter and Boland, 2016). 
Direct defences rely on the plant structure by the construction of a physical barrier either through the formation of a waxy cuticle (Agrawal et al., 2009; Hanley et al., 2007), and/or the development of spines, setae, thorns, and trichomes, (Sharma et al., 2009; He et al., 2011). Structural defences includes morphological and anatomical traits that confer a fitness advantage to the plant by directly deterring the herbivores from feeding (Agrawal et al., 2009) and range from prominent protuberances on a plant to microscopic changes in cell wall thickness as a result of lignifications and suberizations (He et al., 2011; Hanley et al., 2007). The second direct line of defence is the chemical one which includes secondary plant metabolites, protein inhibitors of insect digestive enzymes, proteases, lectins, amino acid deaminases and oxidases. These chemical lines are used by the plant to offset attackers via the production of toxins, along with anti-digestive and anti-nutritive compounds (War et al., 2012, Fürstenberg-Hügg et al., 2013). In addition to direct defence, plants also benefit from indirect defence through the recruitment of natural enemies (i.e. parasitoids or predators) that actively reduce the number of herbivores. Indirect defences generally start with the recognition of insect elicitors, then plants emit and/or receive chemical information from other plants that plays an important role in behavioural choices of individuals, and consequently influences the spatial distribution of populations on larger scales (Vet, 2001; Lof et al., 2008; Vinatier et al., 2011). The combined action of mechanical damages and elicitors from attacking herbivores induces the production of secondary metabolites (Iason et al., 2012) which result in the emission of specific volatile organic compounds (VOCs) called herbivore induced plant volatiles (HIPVs) (Price et al., 1980; Kessler and Baldwin, 2001; Dicke 
and Baldwin, 2010; Hare, 2011). Recently plants have been documented to respond to herbivore oviposition by releasing oviposition-induced plant volatiles (OIPVs) which can recruit egg parasitoids of insect herbivores (Hilker and Meiners, 2010). In some studied cases, a combination of oviposition and feeding activity of the herbivore host was required to trigger natural enemy attraction (Colazza et al., 2010; Conti and Colazza, 2012). These plant volatiles are classified as synomones because they benefit both the emitting plant as well as the responding natural enemy (Vet et al., 1991).

In short, after being attacked by herbivores, plants quickly generate herbivore-specific signals, and through complicated networks, these signals are further converted to large scale biochemical and physiological changes. In addition to these changes in attacked plant parts, certain signals are also conveyed to different parts of the plant where they activate "systemic" defences (Li et al., 2002). Cell membrane depolarization, ion flux, mitogen-activated protein kinase (MAPK) activation, phytohormone modulation, production of reactive oxygen species (ROS) and probably nitric oxide (NO) are all associated with herbivore attack and the activation of these responses (Reymond et al., 2004; De Vos et al., 2005; Bodenhausen and Reymond, 2007; Wu et al., 2007).

The network of phytohormones that plants have is crucial not only for regulating plant growth, development and reproduction, but also for the above mentioned induced defences (production of VOCs). It has been well established that jasmonic acid (JA), salicylic acid (SA) and ethylene (ET) play pivotal roles in the regulation of the signaltransduction pathways that lead to the activation of different sets of 
defence related genes (von Dahl and Baldwin, 2007; Howe and Jander, 2008). In general, defences against biotrophic pathogens and phloemfeeding herbivores are regulated by the phytohormone SA, while defences against necrotrophic pathogens and chewing herbivores are regulated by JA, in particular jasmonic acid-isoleucine (JA-Ile) (Glazebrook, 2005; Erb et al., 2012). Complex hormonal interaction networks enable the tailoring of defences, often via cross-talk, and modulate growth/defence tradeoffs (Pieterse et al., 2012; Huot et al., 2014). Although, abscisic acid $(\mathrm{ABA})$, auxins, gibberellins (GB), cytokinins (CK) and brassinosteroids (BR) have received less attention as potential factors that modulate herbivore resistance, in the recent literature various reports also indicate these hormones to play an important role in mediating specificity in herbivore-induced defence responses (Erb et al., 2012).

\subsubsection{Herbivore induced plant volatiles (HIPVs)}

Herbivore attack results in the induction of plant defences affecting changes in plant quality. However, the level of this induction is not always the same; many factors interact to produce the final response of the damaged plant. This response was shown to differ with herbivore specie (Voelckel and Baldwin, 2004); and also between herbivore strain (Kant et al., 2008). In addition, this response varies subsequently with multiple herbivore species or a singular attack (Voelckel and Baldwin, 2004; Poelman et al., 2008). The order of arrival of different species on the same plant may also determine the defence that is induced, and affect the outcome of interactions among herbivore species (Kessler and Baldwin, 2004; Erb et al., 2011). It has been suggested that species from the same 
feeding guild or sub-guild (Soler et al., 2012) affect each other negatively through the stimulation of the same defensive pathways; whereas, species from different feeding guilds may affect each other positively or not at all due to the negative cross-talk between the different defensive pathways which they induce (Howe and Jander, 2008). Finally, this induced defence can be suppressed by the action of a second attacker (Alba et al., 2011, 2015). Although this is to the benefit of the individuals that suppress plant defences, it may also have positive effects on competitor species (Kant et al., 2015; Godinho et al., 2016).

As described above, when a plant is attacked by an herbivore it emits of a specific blend of volatile compounds known as HIPVs. In the 1980s, the first studies reported the ecological effects of HIPVs when released from damaged plants and target external organisms in a resistance-related context (Fig.1.8) (Heil, 2014). HIPVs are complex blends that can be composed of up to several hundred individual compounds (Pichersky and Gershenzon, 2002; Dudareva et al., 2006; Pichersky et al., 2006). The following definition of HIPVs was suggested by Dicke and Baldwin (2010): "volatiles that a plant produces in response to herbivory. These can either be compounds that a plant does not biosynthesize unless it is damaged or compounds that are also synthesized by undamaged plants but normally in smaller amounts. Because the information content of volatile blends is in the mixture of the compounds, it is also important to consider compounds that are produced by plants but repressed when plants are attacked". 


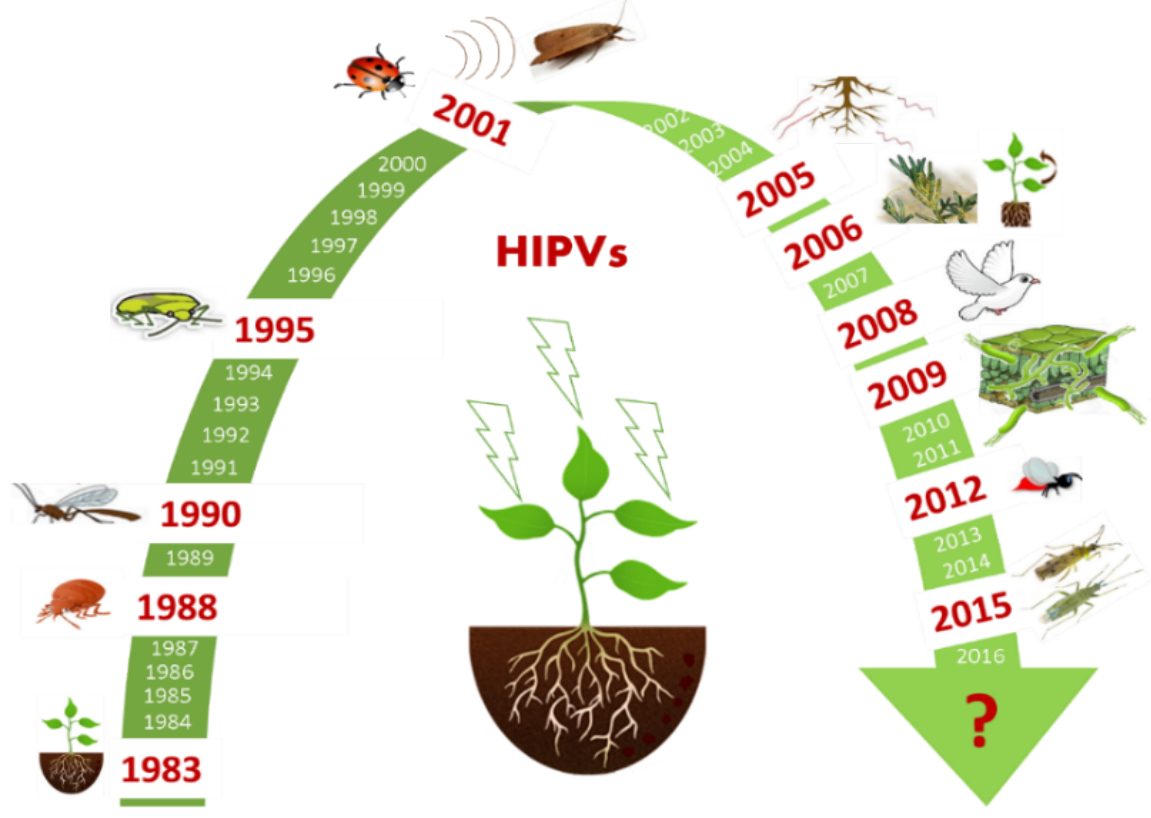

Figure 1.8.

Illustration of milestone articles that depicts the chronology in the discovery of the herbivore induced volatile organic compound (HIPVs) releases that act on the receivers: interplant communication (Baldwin and Schultz, 1983; Rhoades, 1985), predatory mites (Dicke and Sabelis, 1988), parasitoid wasps (Turlings et al., 1990), predatory bugs (Drukker et al., 1995), predatory lady beetles (Ninkovic et al., 2001), herbivorous moths, which are repelled (de Moraes et al., 2001), parasitic plants (Runyon et al., 2006), nematodes (Rasmann et al., 2005), systemic parts of the same plant (Karban et al., 2006), predatory birds (Mäntylä et al., 2008), resistance to pathogens (Yi et al., 2009) and hyperparasitoid (Poelman et al., 2012). Predatory bugs (N. tenuis and M. pygmaeus) induced VOCs via plant feeding behaviour (Pérez-Hedo et al., 2015a; Pappas et al., 2015), adapted from (Heil, 2014).

With more than 1700 currently known compounds (Dudareva et al., 2006), volatiles play an important role in the mechanisms of plant interactions within the environment. Numerous functions are allocated to HIPVs: firstly, they are reported in the concept of "plant-plant communication" via the transfer of information between and within plants. This communication is done through the airborne transport of signals that lead to the priming 
or expression of defences in neighbouring plants or in distal parts of the emitting plant (Baldwin and Schultz, 1983; Rhoades, 1985; Heil and Karban, 2010; Karban et al., 2014). In addition, HIPVs are generally known to mediate tritrophic interactions by attracting herbivore natural enemies, which may confer protection to the plant, referred to as "a cry for help" (Turlings et al., 1990; Dicke et al., 1990; Drukker et al., 1995; Ninkovic et al., 2001). It was also reported that even hyperparasitoids use HIPVs to locate their parasitoid hosts (Poelman et al., 2012). These volatiles can also be used by herbivores to locate suitable hosts or to avoid resistance-expressing plants (repellence effect) (de Moraes et al., 2001; Ballhorn et al., 2013), to inhibit pathogen colonization (Goodrich-Tanrikulu et al., 1995; Zhang et al., 2006), and as reported more recently, to attract herbivores (Bedoya-Perez et al., 2014). In summary, HIPVs aid in the host-location behaviour of diverse animals and enhance the presence of natural enemies that can benefit the emitting plant.

Herbivore induced plant volatiles are released from the disrupted cellular compartments, where they were stored. Such VOCs are released from the damaged sites immediately. They are released through leaf stomata and, in case of the lipophilic volatiles such as terpenes, also through the membrane of epidermal tissues and from other structures, such as trichomes (Baldwin, 2010). Such VOCs can also be emitted from the undamaged sites of plants with some time delay from the moment of the attack (Holopainen and Blande, 2012). VOCs can also be released as newly, "de novo", synthesized compounds. This usually occurs as part of the systemic defence response. The blend of volatiles may vary quantitatively and qualitatively depending on both biotic and abiotic factors, and are specific to each plant-herbivore association and to the nature of the damage (feeding and/or oviposition) (Ingegno et al., 2011; Silva et al., 2017). Plants react distinctly when they are 
attacked by a leaf chewer or by a phloem feeder or when attacked by more than one organism (Dicke et al., 2009; Gosset et al., 2009; Zhang et al., 2009; Zhang et al., 2013). Such specificities and diversity are very important for mediating specific interactions of plants with herbivores, carnivores and other plants (Sabelis et al., 2007; McCormick et al., 2012). Similar to aboveground interactions, below-ground ones can be specific at both the plant and herbivore levels (Dudareva et al., 2006; Rasman and Turling, 2007).

Volatile blends are generally dominated by two major classes of compounds: terpenoids and fatty acid derived green leaf volatiles (GLV) (Arimura et al., 2009; Mumm and Dicke, 2010). Terpenoids represent the largest class of secondary metabolites in plants (Dudareva et al., 2006) and are synthesized via two independent alternative pathways from the five-carbon compound, isopentenyl diphosphate (IDP) and its allylic isomer dimethyl allyl diphosphate (DMAPP). While, green leaf volatiles (GLVs) which are six-carbon compounds including the alcohols, aldehydes and their esters, are formed via the hydroperoxidelyase pathway of oxylipin metabolism (Matsui, 2006). Green leaf volatiles are mainly released immediately upon wounding, while others, including terpenoids, are newly synthesized "de novo" and released from several hours up to several days after attack (Paré and Tumlinson, 1997; Turlings et al., 1998).

\subsubsection{Zoophytophagous predator induced plant defence}

Response of arthropod predators to volatile chemicals emanating from plants infested by their prey has been demonstrated for predatory bugs since 1995 (Drukker et al., 1995; Kessler and Baldwin, 2001). Such evidence has also been obtained for $N$. tenuis, M. pygmaeus and O. laevigatus, who responded to 
the odour emitted from prey infested plants (Moayeri et al., 2006; Ingegno et al., 2011; Lins et al., 2014; De Backer et al., 2015; Rim et al., 2015, 2017; Vaello et al., 2017). Recently, the activity (feeding behaviours and oviposition) of zoophytophagous predators was observed to induce HIPVs (De Puysseleyr et al., 2011; Pérez-Hedo et al., 2015a, 2015b; Pappas et al., 2015, 2016; Naselli et al., 2016). As explained above, these HIPVs can influence the response of phytophagous pests and their natural enemies either by attraction or by repellence (Paré and Tumlinson, 1997). According to Raman et al. (1984), plant feeding of the predatory mirid $N$. tenuis on tomato causes biochemical changes in wounded tissue, leading to increased levels of oxidative enzymes and phenolic compounds which may result in the production of volatile compounds. Halitschke et al. (2011), observed an induction by feeding of mirid Tupiocoris notatus Distant (Hemiptera: Miridae), that renders the native tobacco plant Nicotiana attenuata S. (Solanaceae) more resistant to more damaging herbivores such as hornworms. This special case of induced crossresistance, termed 'plant vaccination', leads to a net benefit for mirid-damaged tobacco plants in their native habitats when multiple herbivore species are present (Kessler and Baldwin, 2004). More recently, Pérez-Hedo et al. (2015a) demonstrated that a $24 \mathrm{~h}$ contact between tomato plant and $N$. tenuis affects the response of the whitefly, $B$. tabaci. The continuous feeding activity of this predator activates the abscisic acid (ABA) and jasmonic acid (JA) signalling pathways in tomato plants; which turn makes it less attractive to B. tabaci, while more attractive to the whitefly parasitoid Encarsia formosa Gahan (Hymenoptera: Aphelinidae). Interestingly, the same authors found N. tenuis activated tomato plants are able to prime neighbouring plants. Certainly, a blend of volatile organic compounds is released in the atmosphere assuring the communication between predatory activated plants and non-activated 
ones, thus, sending out an alert. More confirmation of inducing plant defence in tomato thanks to the phytophagy behaviour of mirids was observed by Pérez-Hedo et al. (2015b). N. tenuis, M. pygmaeus and D. maroccanus tested females differ in their activation potential in tomato after having had contact for 24h. Nesidiocoris tenuis induced, as mentioned above, repellence of B. tabaci and T. absoluta, while E. formosa was attracted to the volatiles emitted by plants previously contacted by $N$. tenuis. In contrast, tomato plants exposed to M. pygmaeus and D. maroccanus for $24 \mathrm{~h}$ were not able to repel B. tabaci and, interestingly, became more attractive to T. absoluta. On the other hand, E. formosa was always attracted to volatiles emitted from predator associated plants. Both studies provide a possible explanation for the great success of these mirids as $\mathrm{BC}$ agents in tomato. Their ability to activate the plant defence mechanisms will undoubtedly improve BC. More evidence was obtained in a recent study conducted by Naselli et al. (2016), showing all motile stages of $N$. tenuis to trigger defensive responses in tomato plants. In fact, young nymphs ( $2^{\text {nd }}-3^{\text {rd }}$ nymphal instars $)$, mature nymphs $\left(4^{\text {th }}-5^{\text {th }}\right.$ nymphal instars), males and females all activate ABA and JA pathways, resulting in reduced attractiveness for $B$. tabaci and enhanced attractiveness for $E$. formosa, relative to undamaged plants with a slight moderation between the considered stages. In addition, Pappas et al. $(2015,2016)$ in agreement with Pérez-Hedo et al. (2015b), demonstrated M. pygmaeus' ability to induce plant defence in tomato crops. These authors showed the exposure of tomato plants to adult M. pygmaeus females, fifth instar nymphs and unmated females (virgin), increased locally and systematically an accumulation of transcripts and activity of proteinase inhibitors. These inhibitors are known to be involved in plant responses, resulting in reduced performance of the subsequently infesting spider mite herbivore, T. urticae, but not of the greenhouse whitefly 
T. vaporariorum. More interestingly, Pappas et al. (2015), showed M. pygmaeus tomato induction vaccinates the plant for a period of two weeks. Therefore, when predators were released in the nursery prior to pest infestation, the defence mechanism was activated with the newly emerged nymphs possibly renewing the induction (Naselli et al., 2016).

Besides the feeding behaviour of the mirid predator, the endophytic oviposition of $O$. laevigatus was shown to increase plant resistance to feeding damage of $F$. occidentalis in tomato. The predator elicits a JA mediated wound response, resulting in reduced thrips feeding. A strong accumulation of hydrogen peroxide $\left(\mathrm{H}_{2} \mathrm{O}_{2}\right)$, a molecule involved in different parts of the wound response, in leaf tissue surrounding the predator eggs or oviposition puncture sites was observed (De Puysseleyr et al., 2011).

Overall, zoophytophagous organisms form community structure by both their predation on herbivores and their phytophagy, resulting in a tomato crop system which is ready to withstand herbivore attack. Despite the importance of this facet of research, literature emphasizing this focus is rare and has begun to be published only recently. Therefore, Chapters 2 and 3 of this thesis focus on the implication of the phytophagous behaviour of O. laevigatus, N. tenuis and M. pygmaeus in inducing defence responses in sweet pepper. The additional effect of defence mechanism stimulation by this predator together with the predacious potential are expected to enhance $\mathrm{BC}$ in this crop (Chapters 4 \& 5). 


\subsection{Thesis outline}

The main aim of my PhD thesis is to enhance sweet pepper pest management through the exploitation of zoophytophagy.

To achieve this goal, four objectives were planned:

- To study sweet pepper plant feeding behaviour by the predatory anthocorid, O. laevigatus and determine whether phytophagous behaviour can induce plant defences by modulating pest and natural enemy behaviour: attraction and repellence.

- To quantify sweet pepper plant feeding behaviour by the predatory mirids, N. tenuis and M. pygmaeus, and determine whether this phytophagous habit can elicit direct defences: antixenosis and attraction by parasitoids.

- To determine the pest management potential of three predatory mirids, N. tenuis, M. pygmaeus and D. maroccanus, against thrips and whiteflies in sweet pepper under two different temperatures.

- To study the impact of species co-occurrence on population dynamics of predatory bugs, O. laevigatus, N. tenuis and M. pygmaeus, with $A$. swirskii and elucidate the potential of combined release for the management of sweet pepper pests. 

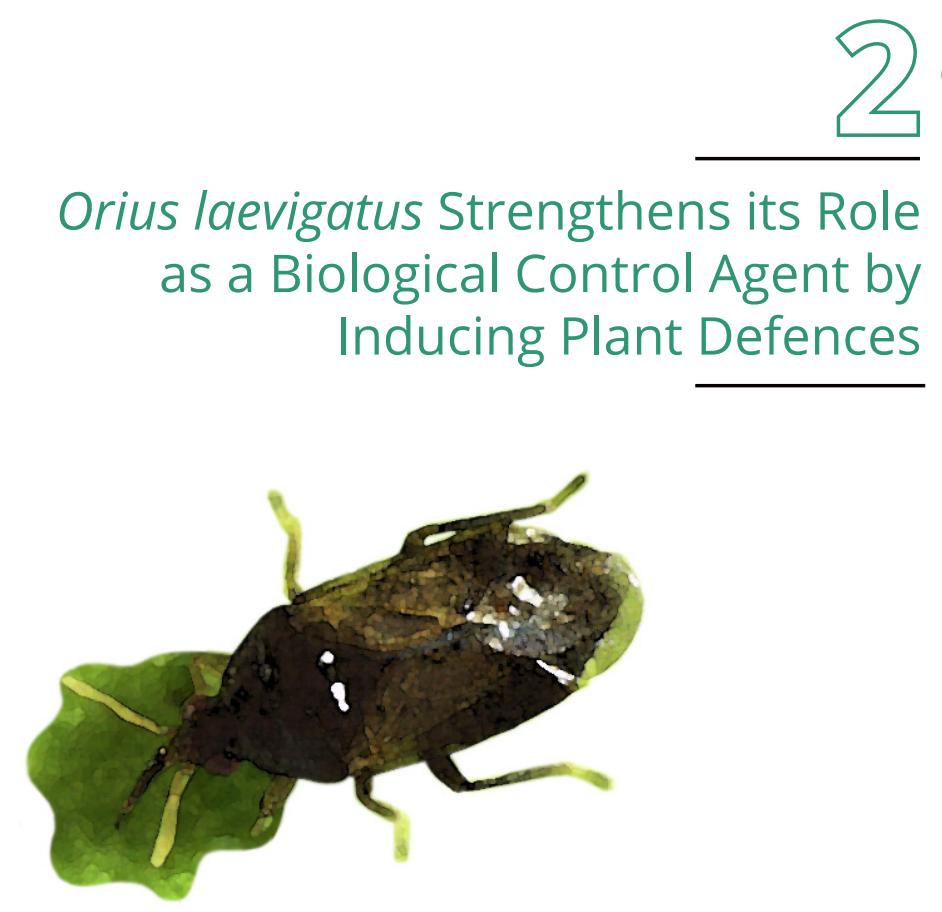



\title{
2 \\ CHAPTER \\ Orius laevigatus Strengthens its Role as a Biological Control Agent by Inducing Plant Defences
}

\author{
Sarra Bouagga, Alberto Urbaneja, José L. Rambla, Antonio Granell, \\ Merityell Pérez-Hedo
}

Journal of Pest Science (2018), 91(1): 55-64

\section{Abstract}

Orius laevigatus is a generalist predator that is widely used in augmentative strategies against the key pest of sweet pepper, Frankliniella occidentalis. Despite being a zoophytophagous predator, the phytophagy behaviour of O. laevigatus has not been previously explored in depth, nor has the impact of phytophagy on plant physiology. Here, the hierarchical significance of O. laevigatus feeding on sweet pepper is compared with other behaviours. Orius laevigatus spends the majority of its time (38\%) feeding on apical meristems and apical fresh leaves, which were also preferred residence locations. Here, the phytophagous feeding behaviour of O. laevigatus on sweet pepper is shown to trigger defensive responses in the plant. These O. laevigatus plant induced defences are then shown to contribute to the repellence or attraction of pests or natural enemies, respectively. Specifically, O. laevigatus-punctured sweet pepper plants induce repellency for the whitefly Bemisia tabaci and the thrips species F. occidentalis. In contrast, the whitefly parasitoid Encarsia formosa was significantly attracted to $O$. laevigatus-punctured plants. The plant responses to O. laevigatus punctures include the release of an altered blend of volatiles and activation of the jasmonate acid and salicylic acid signalling pathways. These results highlight an interesting facet to the biology of O. laevigatus, in which the ability of the predator to induce defensive responses in sweet pepper plants may serve to improve the biological control of both thrips and whiteflies.

KEY wORDs: minute pirate bug, behaviour, plant response, herbivore induced plant volatiles, sweet pepper. 


\subsection{Introduction}

Many species of the genus Orius Wolff, 1811 are considered to be important beneficial insects for a variety of agroecosystems (Hernández and Stonedahl, 1999). Orius species are highly polyphagous, yet show preferential tendencies for immature and adult thrips (Chambres et al., 1993; Ruidavet, 1995; Frescata and Mexia, 1996) and to a lesser extent eggs, nymphs and adult whiteflies (Gerling et al., 2001; Arnó et al., 2008). As a result of these prey preferences, some species of Orius are commercially produced for augmentative release as biological control agents in various crops worldwide (Chambers et al., 1993; Sánchez and Lacasa, 2002; van Lenteren and Bueno, 2003; van Lenteren et al., 2018). In Europe, the minute pirate bug Orius laevigatus Fieber (Hemiptera: Anthocoridae) has become the most successful Orius species for biological control, and it is hence widely used in augmentative release programs. The prey range of O. laevigatus is broad and includes agricultural pests such as aphids, whiteflies, lepidopteran eggs, mites, and thrips with a distinct preference for the latter group of pests (Venzon et al., 2002; van Lenteren and Bueno, 2003). In south eastern Spain, the release of O. laevigatus together with the predatory mite Amblyseius swirskii Athias-Henriot (Acari: Phytoseiidae) is key to successful pest management in more than 10,000 ha of protected sweet pepper crops (Blom et al., 1997; Sánchez et al., 2000; Calvo et al., 2009a; Blom et al., 2009).

The genus Orius can also feed on plants, for example on the pollen and sap, which contributes to population survival in the absence of a primary source of protein-rich food in the crop (Cocuzza et al., 1997; Armer et al., 1998). Indeed, O. laevigatus can complete its development by feeding exclusively on fresh pollen from sweet pepper (Vacante et al., 
1997). Armer et al. (1998) demonstrated that Orius species can also feed on xylem and mesophyll contents, which consists of mostly water with small amounts of sugars, starch and amino acids. The presence of amylase in O. insidiosus Say (Hemiptera: Anthocoridae) indicates that it can digest starch and therefore can take advantage of feeding directly on the plant (Zeng and Cohen, 2000). Plants are not only a source of nutrients but also a substrate for oviposition. Orius females insert their eggs underneath the cuticle in the epidermal to subepidermal cell layers, which enhances offspring survival (Lundgren et al., 2008). During the early developmental stages, O. insidiosus can take nutrients from phloem tissue and survive solely from plant material for several days (Lundgren et al., 2008). All this supports that feeding on plant material is common and ecologically relevant for omnivorous Orius.

Whereas plant-mediated interactions among herbivores have been relatively well-studied, the effect of phytophagy by omnivorous predators on plant defences and the subsequently induced insect behaviour have not been investigated until recently. De Puysseleyr et al. (2011) showed that increased tomato plant resistance to Frankliniella occidentalis Pergande (Thysanoptera: Thripidae) feeding was produced via the jasmonic acid (JA)-mediated wound response during O. laevigatus ovipositing. More recently, several papers have demonstrated the capacity of different species of zoophytophagous species (plant-feeding carnivore), including mirid bugs (Hemiptera: Miridae), to induce plant responses in tomato plants (Pérez-Hedo et al., 2015a, 2015b; Pappas et al., 2015, 2016).

It is hence hypothesised that O. laevigatus would be able to induce plant responses in sweet pepper as has been demonstrated in other plantzoophytophage systems. As a first step to better understand the interaction between $O$. laevigatus and sweet pepper, the behaviour of O. laevigatus on 
the plants was studied and plant feeding behaviour quantified to compare general behaviours. A series of experiments were then conducted to determine whether O. laevigatus feeding punctures on sweet pepper induce plant defence responses and whether these in turn lead to behavioural responses in pest and natural enemy species. In parallel, targeted geneexpression analysis was used on plants previously exposed to O. laevigatus to ascertain which signaling pathways could be involved in plant defensive responses. Finally, the volatile compounds released as part of the plant response to O. laevigatus feeding punctures were characterized.

\subsection{Material and methods}

\subsubsection{Insects and Plants}

Adult O. laevigatus, the whitefly Bemisia tabaci Gennadius (Hemiptera: Aleyrodidae) and the parasitoid Encarsia formosa Gahan (Hymenoptera: Aphelinidae) were supplied by Koppert Biological Systems, S.L. (Águilas, Murcia, Spain), all were less than 5 days old. Frankliniella occidentalis adults were obtained from a colony established at Instituto Valenciano de Investigaciones Agrarias (IVIA) in 2010 and originally collected from Campo de Cartagena (Murcia, Spain). Thrips colonies were maintained on the common bean (Phaseolus vulgaris L. Fabales: Fabaceae) and housed in a climatic chamber at $25 \pm 2{ }^{\circ} \mathrm{C}, 65 \pm 10 \% \mathrm{RH}$ and a 14:10 h (L:D) photoperiod at IVIA.

Pesticide-free sweet pepper seedlings cv ('Lipari') [Capsicum annuum (Solanaceae)] (Dulce italiano, Mascarell semillas S.L, Valencia, Spain) were individually transplanted to plastic pots $(8 \times 8 \times 8 \mathrm{~cm})$ containing a mixture 
of natural soil with local peat moss and housed undisturbed in climatic chamber at $25 \pm 2{ }^{\circ} \mathrm{C}, 60-80 \% \mathrm{RH}$ and 14:10 h (L:D) photoperiod at IVIA. Once the sweet pepper plants had approximately 6 fully developed leaves (approximately $15 \mathrm{~cm}$ in height) they were used for the study of O. laevigatus behaviour, older plants of approximately $20 \mathrm{~cm}$ in height were used for the rest of the experiments.

To obtain O. laevigatus-punctured plants, four intact sweet pepper plants were enclosed for 24 hours in a $60 \times 60 \times 60-\mathrm{cm}$ plastic cage (BugDorm-2 insect tents; MegaView Science Co., Ltd., Taichung, Taiwan) and exposed to 100 O. laevigatus adults, all less than 4 days old (sex ratio 1:1). All individuals were removed from the plants before the experiment. Prior to their use, O. laevigatus were released into a plastic cage $(30 \times 30 \times 30 \mathrm{~cm})($ BugDorm-1 insect tents; MegaView Science Co., Ltd., Taichung, Taiwan) with water supplied on soaked cotton plugs, and starved for twenty-four hours.

\subsubsection{Behaviour of $O$. laevigatus on sweet pepper}

The behaviours of both male and female O. laevigatus on sweet pepper plants in the absence of prey items was observed during 30 minute assays under laboratory conditions ( $\mathrm{T}=25 \pm 2 \stackrel{\circ}{\circ} \mathrm{C}, \mathrm{RH}=60-80 \%$ ). Less than 4-day-old males and presumably mated females of $O$. laevigatus were individually placed inside a plastic 5-ml vial and starved for $24 \mathrm{~h}$ before use. Water was supplied on soaked cotton plugs.

A clean sweet pepper plant was placed inside a $60 \times 60 \times 60 \mathrm{~cm}$ plastic cage (BugDorm-2 insect tents). A single predatory O. laevigatus (male or female) was gently released and observations began once the individual walked freely onto the plant for the first time. The different observed 
behaviours were recorded continuously for 30 minutes. Behavioural observations were made by three researchers using a hand held magnifying glass after first quantifying their reliability. The sweet pepper plant was replaced before the start of each behavioural assay. Observations were repeated until 20 replicates for each sex had been observed.

Locations were defined as off plant (plastic cage, plastic pot or soil) and on plant (distinguishing between apical and basal regions). The apical region was considered the first $5 \mathrm{~cm}$ of the plant formed by the apical stem, young leaves and 2 fully developed leaves. Conversely, the rest of the plant, approximately $10 \mathrm{~cm}$ with 4 fully developed leaves, basal stem and cotyledons, represented the basal region. Seven behavioural states were defined as follows:

- Grooming (G): The predator's forelegs are used to clean mouthparts or another part of the body.

- Feeding (F): The predator inserts its stylet into the plant and stylet movements can be observed.

- Oviposition $(\mathrm{O})$ : The predator presses its whole abdomen onto plant and the ovipositor is inserted into the plant.

- Resting (R): The predator stands motionless.

- Antennating (A): The predator is at rest but moves its antennae.

- Walking $(\mathrm{W})$ : The predator walks on different regions of the plant without moving its antennae.

- Walking-Antennating (WA): The predator walks on different regions of the plant and moves its antennae at the same time.

Because the main interest was in quantifying the feeding behaviour compared to other behaviours, only the analysis of the timed behaviourals grouped in the apical and basal regions of the plant are presented. 


\subsubsection{Plant selection mediated by O. laevigatus}

A Y-tube olfactometer experiment was conducted to test the olfactory responses of B. tabaci, F. occidentalis and E. formosa females to sweet pepper plants that were previously punctured by O. laevigatus relative to intact plants. The Y-tube olfactometer (Analytical Research Systems, Gainesville, FL) consisted of a $2.4 \mathrm{~cm}$ diameter $\mathrm{Y}$-shaped glass tube with a 13.5- $\mathrm{cm}$ long base and two arms each 5.75-cm long (Pérez-Hedo and Urbaneja, 2015). Both side arms were connected via high density polyethylene (HDPE) tubes to two identical glass jars (5 1 volume) each of which connected to an air pump that produced a unidirectional humidified airflow at $150 \mathrm{ml} \mathrm{min}^{-1}$ (Pérez-Hedo and Urbaneja, 2015). Four 60-cm fluorescent tubes (OSRAM, L18W/765, OSRAM GmbH, Germany) were positioned $40 \mathrm{~cm}$ above the horizontally disposed Y-shaped glass tube. The light intensity registered 2,516 lux over the Y-tube and was measured using a ceptometer (LP-80 AccuPAR, Decagon Devices, Inc. Pullman, WA, USA). All Y-tube experiments were conducted under the following environmental conditions, $23 \pm 2{ }^{\circ} \mathrm{C}, 60 \pm 10 \% \mathrm{RH}$.

A single individual female of B. tabaci, F. occidentalis or E. formosa was introduced into the tube (entry array) and observed until she had walked at least $3 \mathrm{~cm}$ up one of the arms or until $15 \mathrm{~min}$ had elapsed. A minimum of 33 valid replicates from each species were recorded for each pair of odor sources. Females that did not choose a side arm within 15 min were recorded as 'no-choice' and were excluded from data analysis. After recording 5 responses, the Y-tube was rinsed with soap water and acetone and left to dry for $5 \mathrm{~min}$. The odor sources were subsequently switched between the left and right side arms to minimize any spatial effect on choice. Both types 
of plants (intact and punctured) were used only once to test the response of 10 females and then were replaced with new plants.

\subsubsection{Plant gene expression analysis}

The apical region of the sweet pepper plants, as defined above, were subjected to targeted gene expression analysis to detect: (i) ASR1 (abscisic acid stress ripening protein 1) a marker gene for ABA, (ii) PIN2 (woundinduced proteinase inhibitor II precursor) a marker gene for JA and (iii) PR1 (basic PR-1 protein precursor) a marker gene for the SA signalling pathway. Samples of the sweet pepper apical region were collected from both intact and O. laevigatus-punctured plants. After homogenization in liquid nitrogen, total RNA was extracted using Trizol (Invitrogen, CA, USA) according to the manufacturer's instructions (Pérez-Hedo et al., 2015a; Naselli et al., 2016). After homogenizing the sample with TRIzol ${ }^{\mathrm{TM}}$ Reagent, chloroform was added to separate RNA of protein and DNA, and subsequent isopropanol and $1.2 \mathrm{Mm} \mathrm{NaCl}$ was added to precipitate the RNA. The RNA pellets resulting from the precipitation were washed twice with $70 \%$ ethanol, dried at room temperature and eluted in water. The RNA was quantified and then treated with the Turbo DNA-free DNase kit (Applied Biosystems) to eliminate any traces of genomic DNA, according to the manufacturer's protocol. cDNA was synthesized by adding to the samples $(1 \mu \mathrm{g} / \mu \mathrm{l})$, RT buffer, $10 \mu \mathrm{M}$ Oligo dT and prime script ${ }^{\mathrm{TM}} \mathrm{RT}$ reagent kit (perfect real time) (TAKARA Bio, CA, USA). The reaction mixture was then incubated in the thermo-cycler for $15 \mathrm{~min}$ at $37^{\circ} \mathrm{C}$ and for $5 \mathrm{~s}$ at $85^{\circ} \mathrm{C}$. Real-time PCR amplifications were performed with Maxima SYBR Green qPCR Master Mix (Thermo Fisher Scientific, MA, USA). Capsicum annuum forward and reverse 
specific primers $(0.5 \mu \mathrm{l})$ were designed and added to $5 \mu \mathrm{l}$ of Syber green/ ROX qPCR MM and $1 \mu \mathrm{l}$ of cDNA and then brought to $10 \mu \mathrm{l}$ total volume with Milli-Q sterile water. PCR reactions were run in duplicate according to manufacturer recommendations. Quantitative PCR was carried out using the LightCycler ${ }^{\circledR} 480$ System (Roche Molecular Systems, Inc., Switzerland) and the protocol consisted in $95^{\circ} \mathrm{C}$ for $10 \mathrm{~min}$ followed by 40 cycles of $95{ }^{\circ} \mathrm{C}$ for $15 \mathrm{~s}, 56^{\circ} \mathrm{C}$ for $30 \mathrm{~s}$ and $72{ }^{\circ} \mathrm{C}$ for $30 \mathrm{~s}$. Melting curve analysis was performed at $95{ }^{\circ} \mathrm{C}$ for $5 \mathrm{~s}, 60{ }^{\circ} \mathrm{C}$ for $1 \mathrm{~min}$ and then a continuous increase of temperature until $95{ }^{\circ} \mathrm{C}$ finalizing the process. Data acquisition and calculation were performed with the thermal cycler's software and then were collected and analyzed in Microsoft Excel. Each qPCR data point is the average of 8 independent experiments. EF1 (elongation factor-1) was used as a standard control gene for normalization. The nucleotide sequences of the gene-specific primers are described in Table 2.1.

Table 2.1.

Forward and reverse sequences of ASR1, PIN2, PR1, and the constitutive gene EF1.

\begin{tabular}{lll}
\hline Primers & Forward & Reverse \\
\hline ASR1 & 5'-TGTGCAATTTGTCTTGTGGAA-3' & 5'-CGGACATGACGAGTTCGATA-3' \\
\hline PIN2 & 5'-CTTGCCCCAAGAATTGTGAT-3' & 5'-GCCCTAGCGTATTACGGAGA-3' \\
\hline PR1 & 5'-ACGTCTTGGTTGTGCTAGGG-3' & 5'-CCATACGGACGTTGTCCTCT-3' \\
\hline EF1 & 5'-CCTGGACAGATTGGAAATGG-3' & 5'-GACCACCTGTCGATCTTGGT-3' \\
\hline
\end{tabular}




\subsubsection{Composition of volatile blends}

Volatile compounds were collected by means of solid phase microextraction (SPME) and separated and detected by means of gas chromatography coupled to mass spectrometry (GC/MS). Volatiles were adsorbed in a 65- $\mu \mathrm{m}$ PDMS/DVB SPME fiber (polydimethylsiloxane/ divinylbenzene; Supelco, Bellefonte, PA, USA). The adsorbent-coated fiber was mounted on an SPME fiber holder, and injected through the first septum of the sample container. Agitation of the atmosphere inside the container was achieved by pumping at $5 \mathrm{ml} / \mathrm{min}$ using an injected syringe through the second septum of the sample container.

Each sample was performed for 3 hours. Four replicates for the intact plant and three replicates for O. laevigatus-punctured plant treatments were conducted. After collection, the fiber was retracted into the needle and the SPME device was removed from the container for GC-MS analysis.

Desorption was performed by means of a CombiPAL autosampler (CTC Analytics) at $250^{\circ} \mathrm{C}$ for $1 \mathrm{~min}$ in splitless mode in the injection port of a $6890 \mathrm{~N}$ gas chromatograph coupled to a 5975B mass spectrometer (Agilent Technologies). To prevent cross-contamination, fibers were cleaned after desorption in an SPME fiber conditioning station (CTC Analytics) at $250{ }^{\circ} \mathrm{C}$ for $5 \mathrm{~min}$ under helium flow. Chromatography was performed on a DB-5ms $(60 \mathrm{~m}, 0.25 \mathrm{~mm}, 1.00 \mu \mathrm{m})$ column with helium as carrier gas, at a constant flow of $1.2 \mathrm{ml} / \mathrm{min}$. The GC interface and MS source temperatures were $260{ }^{\circ} \mathrm{C}$ and $230{ }^{\circ} \mathrm{C}$, respectively. Oven programming conditions were $40{ }^{\circ} \mathrm{C}$ for $2 \mathrm{~min}, 5^{\circ} \mathrm{C} / \mathrm{min}$ ramp until $250{ }^{\circ} \mathrm{C}$, and a final hold at $250{ }^{\circ} \mathrm{C}$ for $6 \mathrm{~min}$. Data were recorded in the $35-300 \mathrm{~m} / \mathrm{z}$ range at $5 \mathrm{scans} / \mathrm{s}$, with electronic 
impact ionization at $70 \mathrm{eV}$. Untargeted analysis of the chromatograms was performed with MetAlign software (WUR, http://www.metalign.nl).

Kovats retention indexes (KIs) were calculated for the compounds. Differentially emitted compounds were first tentatively identified by the comparison of their mass spectra with those in the NIST 05 Mass Spectral Library. When available, identity was confirmed by coelution with pure standards (Sigma-Aldrich). To quantify the selected compounds, one specific ion was selected for each compound, and the corresponding peak area from the extracted ion chromatogram was integrated by means of the ChemStation E.02.02 software (Agilent Technologies). The criteria for ion selection were the highest signal-to-noise ratio and specificity to that particular region of the chromatogram to provide good peak intergration.

\subsubsection{Data analysis}

The different behaviours of O. laevigatus on sweet pepper plants and the predator location were analyzed using three-way analysis of variance (ANOVA), taking as factors, sex, observer researcher and either behaviour or location. Tukey's test was used for mean separation at $\alpha<0.05$. Since only three of the 20 tested female O. laevigatus oviposited on plants, this behaviour was excluded from the analysis. The data from the olfactory responses were analyzed using a $\chi^{2}$ goodness of fit test based on a null model where the odor sources were selected with equal frequency. Individuals who did not make a choice were excluded from the statistical analysis. The data from gene expression analyses and volatile profiling were analyzed using one-tailed Student's $t$-test $(P<0.05)$. For volatile profiling, discriminant compounds 
were determined by the analysis of the data obtained from the untargeted chromatogram and the results expressed as the means \pm standard error.

\subsection{Results}

\subsubsection{Behaviours and locations of O. laevigatus on sweet pepper}

Orius laevigatus showed preference to the apical region of the sweet pepper plants where the majority of the observed behaviours were performed $\left(F_{2,110}=108.33 ; P<0.0001\right)$ (Fig.2.1). Neither sex nor the observer researcher was found to be significant $\left(F_{1,110}=0.11 ; P=0.7415\right.$ and $F_{2,110}=0.06 ; P=0.9374$, respectively).

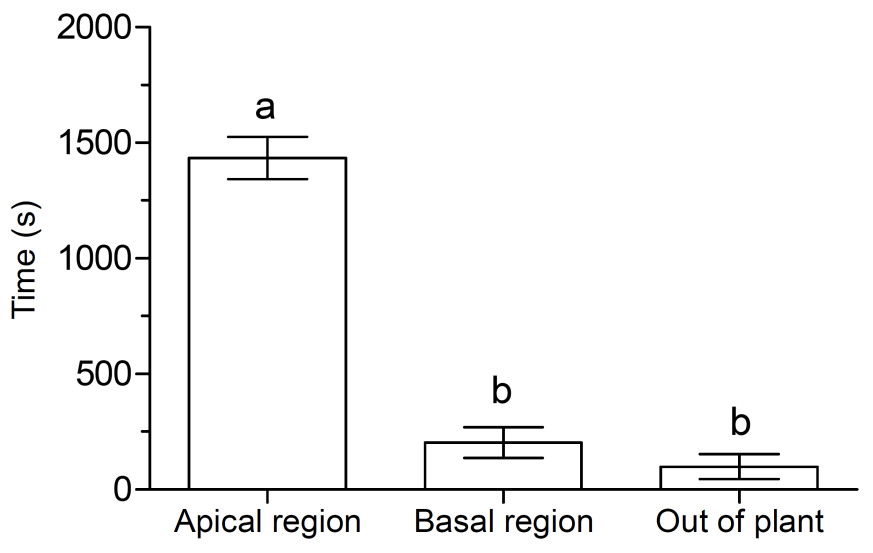

Figure 2.1.

Residence time (mean \pm $\mathrm{SE}$ ) of $O$. laevigatus adults on sweet pepper plants. Bars with different letters are significantly different (ANOVA, Tukey's multiple comparison test $a<0.05$ ) $(n=40)$. 
Orius laevigatus spent $38 \%$ of their time feeding on plant tissues, which was significantly higher than the time spent on all other activities $\left(F_{5,221}=21.01 ; P<0.0001\right)$ (Fig.2.2). Neither the sex nor the observer were significant in the statistical analysis of the behaviours, $\left(F_{1,221}=0.12 ; P=0.724\right.$ and $F_{2,221}=0.48 ; P=0.6211$, respectively).

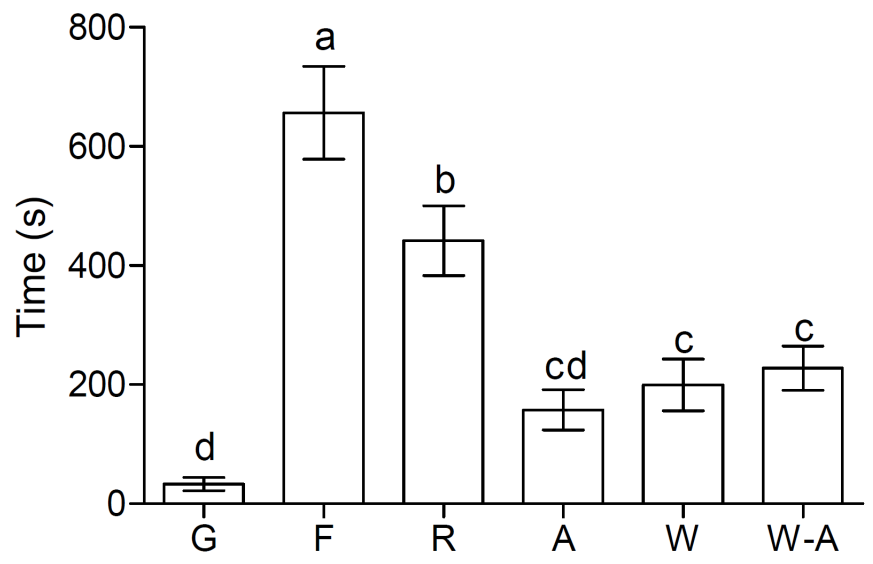

2.3.2. Plant selection mediated by 0 . laevigatus
Figure 2.2.

Time (mean \pm SE) spent exhibiting different behaviours by 0 . laevigatus adults on sweet pepper plants during a period of $30 \mathrm{~min}$. Bars with different letters are significantly different (ANOVA, Tukey's multiple comparison test $a<0.05)(n=40)$.

In the Y-tube experiment, females of F. occidentalis showed preference for the odor emitted from intact plants over that from O. laevigatuspunctured plants $\left(\chi^{2}=19.931 ; P<0.0001\right)$ (Fig.2.3). In the case of B. tabaci, tested females were also attracted to the odor emitted by intact sweet pepper plants in comparison to O. laevigatus-punctured plants $\left(\chi^{2}=17.071 ; P<0.0001\right)$ (Fig.2.3). In contrast to both phytophagous insects, the parasitoid E. formosa significantly chose O. laevigatus-punctured plants over intact plants in the olfactometer assay $\left(\chi^{2}=6.250 ; P=0.0124\right)$ (Fig.2.3). 


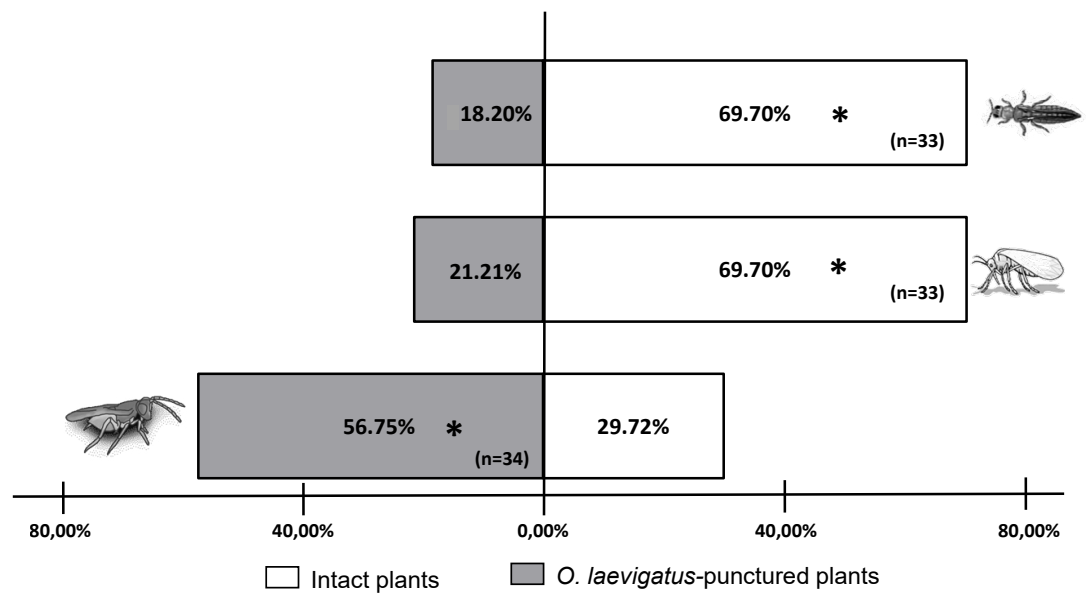

Figure 2.3.

Response in Y-tube olfactometer of females of F. occidentalis $(n=33), B$. tabaci $(n=33)$ and E. formosa $(\mathrm{n}=34)$ to the odor emitted by intact sweet pepper and by sweet pepper plants previously exposed to 0 . laevigatus. Significant differences based on a $\chi 2$-test are marked using * $(P<0.05)$.

\subsubsection{Plant gene expression analysis}

Transcriptional analysis showed that plant feeding by O. laevigatus on the apical portion of sweet pepper plants increased the expression of the PIN2 gene (JA pathway) ( $t=2.161, P=0.019)$ and the $P R 1$ gene (SA pathway) ( $t=1.835, P=0.039$ ) (Fig. 2.4.a,b). In contrast, the ASR1 gene (ABA pathway) was not affected in O. laevigatus-punctured plants $(t=0.113, P=0.455)$ (Fig.2.4.c). 
a)

\section{PIN2}

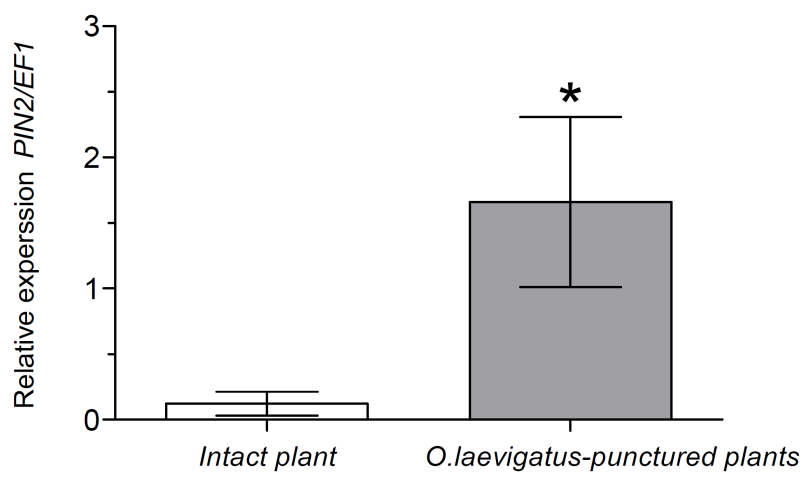

b)

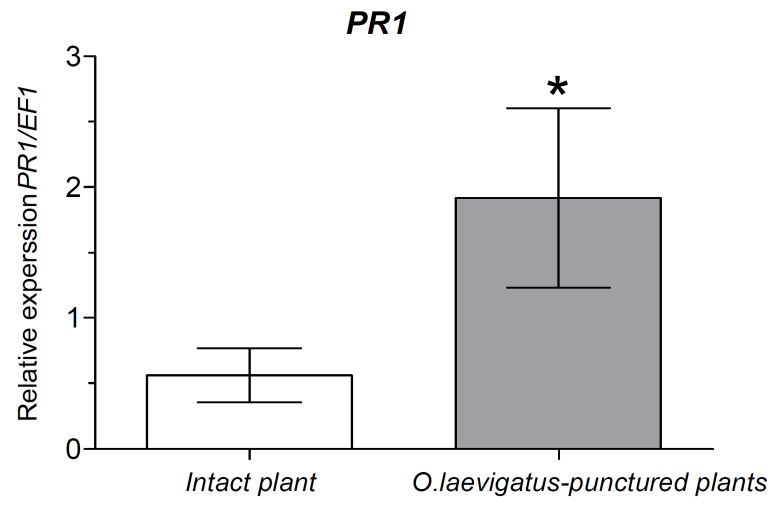

c)

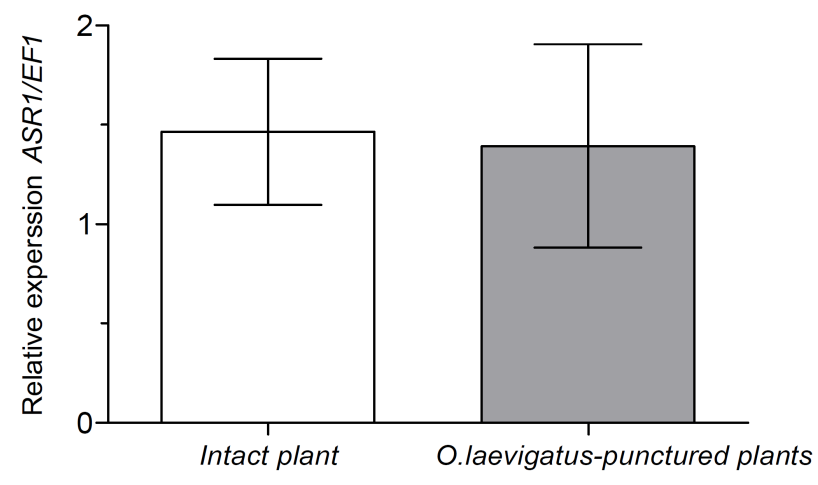

Figure 2.4.

Transcriptional response of the defensive genes ASR1 (a), PIN2 (b) and PR1 (c) responsible for the change in level of the phytohormones ABA, JA, and SA, respectively, in o. laevigatus- punctured plants. Data are presented as the mean of eight independent analyses of transcript expression relative to a housekeeping gene \pm SE $(n=8)$. Significant differences based on $t$ - test are marked with (*) $(P<0.05)$. 


\subsubsection{Composition of volatile blends}

Quantitative differences were recorded in the herbivore-induced plant volatiles (HIPVs) profile of O. laevigatus-punctured and intact sweet pepper plants. Untargeted analysis of the volatiles emitted allowed the identification of ten compounds with significantly increased levels in punctured plants, while no compounds with decreased levels were identified. The emission of discriminant compounds increased in the range of 2 to 100-fold and corresponded to terpenoids (1 monoterpenoid, 4 sesquiterpenoids and 1 norisoprenoid), a set of two (Z)-3-hexenyl esters, methyl salicylate and another unknown compound (Table 2.2).

Table 2.2.

Significant relative levels (fold changes) of the volatiles emitted by 0 . laevigatus punctured plants relative to intact plants. Student's t-test $(P<0.05)$.

\begin{tabular}{lllccc}
\hline \multirow{2}{*}{ Type } & \multicolumn{1}{c}{ Compound } & $\begin{array}{c}\text { Kovats } \\
\text { Rl }\end{array}$ & $\begin{array}{c}\text { Fold } \\
\text { change }\end{array}$ & $t$ & $P$ \\
\hline $\begin{array}{l}\text { Terpenoids: } \\
\text { monoterpenoids }\end{array}$ & Linalool $^{*}$ & 1103 & 6.42 & 2.5353 & 0.0327 \\
\hline & Sesquiterpene $^{1}$ & 1418 & 33.80 & 4.593 & 0.0029 \\
\cline { 2 - 6 } $\begin{array}{l}\text { Terpenoids: } \\
\text { sesquiterpenoids }\end{array}$ & Sesquiterpene $^{2}$ & 1459 & 4.30 & 6.739 & 0.0005 \\
\cline { 2 - 6 } & (E)-nerolidol $^{*}$ & 1574 & 7.55 & 7.036 & 0.0004 \\
\cline { 2 - 6 } & Sesquiterpenoid $^{2}$ & 1583 & 97.95 & 2.557 & 0.0254 \\
\hline $\begin{array}{l}\text { Terpenoids: } \\
\text { norisoprenoids }\end{array}$ & Unknown $^{3}$ & 1117 & 4.30 & 2.71 & 0.0211 \\
\hline $\begin{array}{l}\text { Green leaf volatile } \\
\text { esters }\end{array}$ & (Z)-3-hexenyl propanoate $^{*}$ & 1096 & 3.04 & 2.353 & 0.0327 \\
\cline { 2 - 6 } $\begin{array}{l}\text { Systemic acquired } \\
\text { resistance (SAR) }\end{array}$ & Methyl salicylate $^{*}$ & 1596 & 3.10 & 5.722 & 0.0011 \\
\hline Other & Unknown $^{4}$ & 1664 & 2.52 & 2.151 & 0.0421 \\
\hline
\end{tabular}

*Unequivocal identification (confirmed with a pure standard); Tentative identification based on mass spectra: ${ }^{1}$ beta-elemene, ${ }^{2}$ alpha-bergamotene, ${ }^{3}$ norisoprenoid (C11H18) and ${ }^{4}$ methyl dihydrojasmonate 


\subsection{Discussion}

Here, for the first time O. laevigatus induced defensive response in sweet pepper plants due to the described phytophagy behaviour. This is of particular interest as the predator $O$. laevigatus has been one of the most studied and successfully used augmentative biological control agents in sweet pepper (van Lenteren et al., 2018). Furthermore, the modulated behaviour of both pest species (B. tabaci and F. occidentalis) and a natural enemy (E. formosa) associated with sweet pepper, in response to an induced plant response by the zoophytophage O. laevigatus, is documented for the first time.

Previous studies on the behaviour of several species of Orius under different conditions (availability of prey and/or pollen, quality of the plant as a feeding and/or oviposition substrate, architecture of the plant) have been reported (Fritshe and Tamó, 2000; Yano et al., 2005; Jonathan and Fergen, 2006; Lundgren et al., 2008). However, to our knowledge, no other study has quantified the time that a specific Orius species spends feeding on sweet pepper. Here, O. laevigatus feeding behaviours are described and quantified, and reveal both females and males feed on plant tissue by inserting their stylets, a behaviour which represents $38 \%$ of time spent on the plant. When comparing this plant feeding behaviour with the other observed behaviours under experimental conditions, plant feeding was the preferred activity by $O$. laevigatus, occupying the greatest proportion of time. Individuals tested in the behavioural experiment were starved 24 hours, with access to just water, before their release into the experimental arenas. The reason for both female and male O. laevigatus plant feeding behaviour upon their release could well be due to the need to obtain nutrients from the plant and not so 
much because of the need for hydration. Indeed, the sequential behaviour of importance was searching for prey (the sum of the Antennating-A and “Walking-Antennating-WA behaviour). The experimental conditions (starved O. laevigatus, the size of sweet pepper plants and the absence of prey after release) were standardised according to conditions O. laevigatus would encounter in the field when released in augmentative biological control programs. The next step would be to quantify the plant feeding behaviour in the presence of prey in sweet pepper plants, and whether under this situation, defensive plant responses are also activated.

It is known that predators avoid laying eggs where prey are scarce or absent as in our study (Evans and Dixon, 1986; Hemptinne et al., 1992). Nakashima and Hirose (2002) observed that females of O. sauteri Poppius (Hemiptera: Anthocoridae) oviposited at higher rates in prey-rich patches than in prey-deficient patches. O. laevigatus individuals used in this study were subjected to a very similar procedure before their use (starvation with access to water for $24 \mathrm{~h}$ ) as in Nakashima and Hirose (2002), and only three of the 20 tested females of O. laevigatus oviposited on plants. The time represented by oviposition occupied just $0.2 \%$ of total observation time. These results suggest that plant defence response can be induced by plant feeding behaviour in addition to the oviposition behaviour described by De Puysseleyer et al. (2011) in tomatoes. Recently, Naselli et al. (2016) demonstrated that all motile stages of the mirid Nesidiocoris tenuis Reuter (Hemiptera: Miridae) can induce plant responses in tomato plants, although such responses may differ slightly depending on the stage considered. Similarly, knowing if immature O. laevigatus individuals can trigger defensive responses in sweet peppers would also be of interest. 
Most of the plant defence mechanisms against insects are activated by signal transduction pathways mediated by JA, SA and ethylene (Shivaji et al., 2010; Gill et al., 2010). Little had previously been described on the subject of plant responses to the feeding of O. laevigatus before this study. It is shown here that activation of the JA and SA pathways in O. laevigatuspunctured plants is associated with aversion of both arthropod pests, B. tabaci and F. occidentalis and by contrast, the whitefly parasitoid E. formosa was significantly attracted to O. laevigatus-punctured plants. Pérez-Hedo et al. (2015a) observed that the feeding activity of the predatory mirid N. tenuis on tomato plants activated the ABA and JA signaling pathways, which made plants exposed to mirids less attractive to $B$. tabaci and more attractive to E. formosa. Additionally, Pérez-Hedo et al. (2015b) showed that three different zoophytophagous predators [N. tenuis, Macrolophus pygmaeus Rambur and Dicyphus maroccanus Wagner (Hemiptera: Miridae)] had different capacities to induce specific responses in tomato plants. Tomato plants exposed to $N$. tenuis were less attractive to $B$. tabaci as mentioned above but also to the lepidopteran Tuta absoluta Meyrick (Lepidoptera: Gelechiidae). By contrast, tomato plants exposed to $M$. pygmaeus and D. maroccanus were not able to repel $B$. tabaci and, more interestingly, became more attractive to T. absoluta. All three zoophytophagous mirid predators activated the JA signaling pathways, which resulted in the attraction of the parasitoid E. formosa to punctured tomato plants.

Pappas et al. (2015, 2016) observed that the performance of Tetranychus urticae Koch (Acari: Tetranychidae) decreased as a result of the prior exposure of tomato plants to M. pygmaeus. This was accompanied by a locally and systematically increased accumulation of transcripts and activity of proteinase inhibitors that are known to be involved in plant responses. 
Similarly, a further step in the research with O. laevigatus will be to investigate the performance, by evaluating different life history traits, of B. tabaci and F. occidentalis on O. laevigatus-punctured plants.

It is well documented that non-consumptive effects triggered by arthropod predators can modulate behaviour, physiology, development and morphological traits of a subsequently infesting herbivore (Werner and Peacor, 2003). This non-consumptive effect relies on the ability of prey to perceive chemicals and visual cues directly emitted by predators, before being preyed. Escape, avoidance, reduced oviposition, reproduction and reduced feeding are some of the solutions prey employ to avoid predation risk (Nomikou et al., 2003; Sendoya et al., 2009; Ninkovic et al., 2013; Wasserberg et al., 2013; Lee et al., 2014). No chemical compound has yet been isolated which could be related to an O. laevigatus chemical cue, since all differentially identified chemical compounds were emitted from the plant. Therefore, the responses of B. tabaci, F. occidentalis and E. formosa were a direct consequence to the odor emitted from the O. laevigatus-punctured sweet pepper plants.

The results presented here showed increased emission of HIPVs in sweet pepper punctured by $O$. laevigatus compared to intact plants. These volatiles belong to already identified volatile groups activated in plants being injured by true phytophagy, the green leaf volatiles group (GLVs), terpenoids and methyl salicylate (Kessler and Baldwin, 2001; Kessler and Baldwin, 2002; War et al., 2011). It is known that HIPVs are released by most plant species (McCormick et al., 2014). However, each species of plant could emit a specific blend of volatiles and that the relative amounts of HIPVs could vary widely between species and with the type of damage (Kigathi et al., 2009; Ponzio et al., 2014; Ardanuy et al., 2016). In this chapter, it has 
been shown that the particular volatile profile emitted by the O. laevigatuspunctured plant repelled B. tabaci and F. occidentalis and attracted E. formosa. In summary, these results show that the effectiveness of $O$. laevigatus as a biological control agent in sweet pepper is due to not just its predatory role but also to its ability to induce plant defensive responses. These results open the doors to new management methods for B. tabaci and F. occidentalis. Once the volatile(s) responsible for the repellency of both pests have been identified, new repellent products can be developed. In parallel, plant breeding programs aimed at obtaining plants with an ability for greater emission of these volatiles could be implemented. 

Zooohytophagous Mirids Provide Pest Control by Inducing Direct Defences, Antixenosis and Attraction to Parasitoids in Sweet Pepper Plants
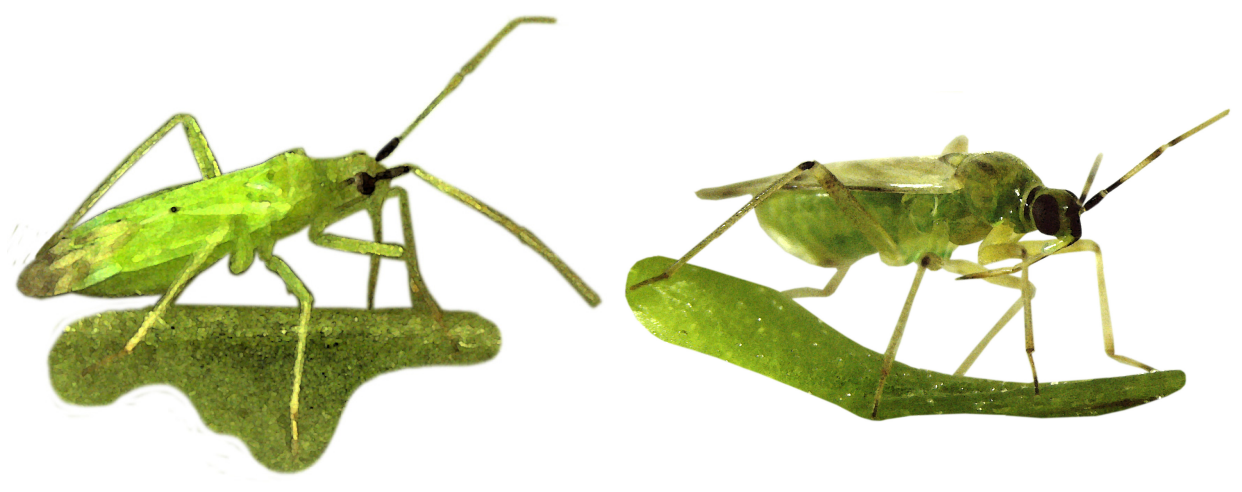



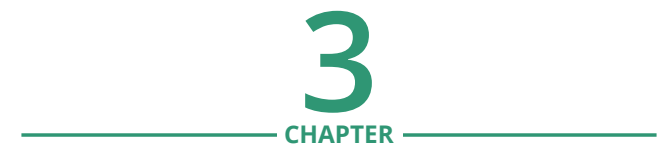

\title{
Zoophytophagous Mirids Provide Pest Control by Inducing Direct Defences, Antixenosis and Attraction to Parasitoids in Sweet Pepper Plants
}

\author{
Sarra Bouagga, Alberto Urbaneja, José L. Rambla, Víctor Flors, Antonio Granell, \\ Josep A. Jaques, Meritxell Pérez-Hedo
}

Pest Management Science (2017), DOI: 10.1002/ps.4838

\section{Abstract}

In addition to their services as predators, mirid predators are able to induce plant defences by phytophagy. However, whether this induction occurs in sweet pepper and whether it could be an additional benefit to their role as biological control agent in this crop remains unknown. Here, these questions are investigated in two model insects, the mirids Nesidiocoris tenuis and Macrolophus pygmaeus.

Plant feeding behaviour was observed in both N. tenuis and M. pygmaeus on sweet pepper and occupied $33 \%$ and $14 \%$ of total time spent on the plant respectively. The punctures caused by mirid plant feeding induced the release of a blend of Volatile Organic Compounds (VOCs) which repelled the herbivore pests Frankliniella occidentalis and Bemisia tabaci and attracted the whitefly parasitoid Encarsia formosa. The repellent effect on B. tabaci was observed for at least 7 days after initial exposure of the plant to $N$. tenuis, and attraction of E. formosa remained functional for 14 days.

Feeding induced plant defences by mirid predators, their subsequent effects on both pests and natural enemy behaviour, and the persistence of these observed effects open the door to new control strategies in sweet pepper crop. Further application of this research is discussed, such as the vaccination of plants by zoophytophagous mirids in the nursery before transplantation.

Key words: Nesidiocoris tenuis, Macrolophus pygmaeus, phytophagy, HIPV's, plant response, vaccination. 


\subsection{Introduction}

Predatory mirid bugs (Hemiptera: Miridae) have been extensively studied in the last few decades for their ecological significance and role as predators of agricultural pests (Schaefer et al., 2000; Wheeler, 2001). In recent studies, their importance as biocontrol agents in sweet pepper has been highlighted (Messelink et al, 2011a, 2015; Pérez-Hedo and Urbaneja, 2015). The use of generalist natural enemies in sweet pepper crops is widely common and has been proven successful (Sánchez and Lacasa, 2002; van Lentren, 2012; van Lentren et al., 2018). If properly managed, the release and the conservation of the predatory mite, Amblyseius swirskii Athias-Henriot (Acari: Phytoseiidae) together with the anthocorid Orius laevigatus Fieber (Hemiptera:Anthocoridae) can successfully manage the population of the key pepper pests; sweet potato whitefly, Bemisia tabaci Gennadius (Hemiptera: Aleyrodidae), greenhouse whitefly, Trialeurodes vaporariorum Westwood (Hemiptera: Aleyrodidae) and western flower thrips, Frankliniella occidentalis Pergande (Thysanoptera: Thripidae) (Calvo et al., 2012a, Weintraub, 2011). Moreover, the polyphagous behaviour of A. swirskii and O. laevigatus contribute to the management of secondary pests, such as spider mites and Lepidoptera (Park et al., 2010; van Maanen et al., 2010). In this system aphids manage to evade the control of both predators (Belliure et al., 2008, Sánchez et al., 2011) and so the multiple release of natural enemy species is usually practiced, which can have considerable implications in the final cost of the biocontrol program in this crop (Blom et al., 2008; Messelink et al., 2011a). Alternative biocontrol strategies in which mirid predators are included have hence been recently explored. Nesidiocoris tenuis Reuter, Macrolophus pygmaeus Rambur and Dicyphus maroccanus Wagner (Hemiptera: 
Miridae) were shown to effectively control the aphid Myzus persicae Sulzer (Hemiptera: Aphididae) on sweet pepper (Pérez-Hedo and Urbaneja, 2015). Furthermore, M. pygmaeus was found to be the most effective agent for the control of M. persicae in sweet pepper when compared with three other mirid species, Dicyphus errans Wolff, D. tamaninii Wagner and Deraeocoris pallens Reuter (Hemiptera: Miridae) (Messelink et al., 2015). Under combined release, intraguild interactions between M. pygmaeus and O. laevigatus did not result in population imbalances of either predatory species, but a better control strategy for both thrips and aphids on sweet pepper resulted (Messelink and Janssen, 2014).

Within the mirids, omnivory is common (Wheeler, 2001) and they are able to exploit both plant and prey resources during the same developmental stage (Castañé, 2011; Sánchez et al., 2016). This flexibility in their behaviour increases survival rates by taking advantage of plant resources when prey is either less abundant or completely absent (Sánchez et al., 2004; Urbaneja et al., 2005; Biondi et al., 2016). As in herbivores, the phytophagous behaviour of mirid predators may also induce indirect plant defences (Pérez-Hedo et al., 2015a, 2015b; Pappas et al., 2015, 2016; Naselli et al., 2016). It is well known that plants can respond to the damage induced by phytophagous insects, involving several signal transduction pathways that are mediated by phytohormones. Jasmonic acid (JA), salicylic acid (SA), abscisic acid (ABA) and ethylene (ET) are the main targeted components and their accumulation in the plant activates signalling cascades that regulate transcriptional response (Burce and Pickett, 2007; How and Jander, 2008; Bari and Jone, 2009; Karban, 2011; Dicke and van Loon, 2014). Indeed, plants damaged by herbivores often produce a blend of volatiles, commonly referred to as herbivore induced plant volatiles (HIPV's) (Takabayashi and 
Dicke, 1996; Paré and Tumlinson, 1999; Mumm and Dicke, 2010; Nasseli et al., 2017). These HIPV's consist of a mixture of the so-called green-leaf volatiles ( $\mathrm{C}_{6}$ aldehydes, alcohols and esters), terpenes (monoterpenes, sesquiterpenes, homoterpenes) and aromatic compounds among others (Arimura et al., 2009; Pichersky, 2006). Consequently, natural enemies use the change in the composition and concentration of these released volatiles as a cue for the presence of potential prey or hosts (Sabelis et al., 1999; Dicke and van Loon, 2000; Verkerk, 2004).

In this work, the potential of $N$. tenuis and M. pygmaeus to induce plant defences in sweet pepper is investigated and whether this could be an additional benefit to their role as a biological control agent in this crop. The behaviour of $N$. tenuis and $M$. pygmaeus on sweet pepper was first explored in order to quantify feeding activity on the crop. Secondly, the level of the phytohormones involved in the plant defence and the expression of several marker genes was evaluated, both in intact plants (without mirids punctures) and in mirid-punctured plants. A non-targeted analysis of the volatile compounds differentially released by mirid-punctured and intact plants was then performed by means of headspace solid phase microextraction (HS-SPME) coupled to gas chromatography-mass spectrometry (GC-MS). Thirdly, the response of two key sweet pepper pests, F. occidentalis and B. tabaci, and the whitefly parasitoid Encarsia formosa Gahan (Hymenoptera: Aphelinidae) to the odour emitted by mirid-punctured and intact plants was tested under dual choice experiments. Finally, the persistence of the plant response induced by $N$. tenuis was observed. 


\subsection{Material and Methods}

\subsubsection{Plants and insects}

Pesticide free Capsicum annuum (cv. Lipari) (Dulce italiano, Mascarell semillas S.L, Valencia, Spain) seedlings were used for the study. Two weeks after germination, seedlings were transplanted into a mixture of soil and local peat moss in plastic pots $(8 \times 8 \times 8 \mathrm{~cm})$, housed in climatic chambers at $25 \pm 2{ }^{\circ} \mathrm{C}, 60-80 \% \mathrm{RH}$ and 16:8 h (L:D) photoperiod at Instituto Valenciano de Investigaciones Agrarias (IVIA). Plants with 6 fully-developed leaves (approximately $15 \mathrm{~cm}$ in height) were used for the study of $N$. tenuis and M. pygmaeus behaviour and for the rest of the experiments plants were used once 10 leaves had fully-developed (approximately $20 \mathrm{~cm}$ in height). Two sweet pepper plant treatments were required, mirid-punctured plants and intact plants (control plants free from any arthropod contact). Mirid-punctured plant were obtained by exposing sweet pepper plants to 25 adult $N$. tenuis or M. pygmaeus (sex ratio 1:1) for 24 hours in a $30 \times 30 \times 30-\mathrm{cm}$ plastic cage (BugDorm-1 insect tents; MegaView Science Co., Ltd., Taichung, Taiwan).

Nesidiocoris tenuis, M. pygmaeus and B. tabaci adults, and E. formosa pupae, were provided by Koppert Biological Systems, S.L. (Águilas, Murcia, Spain). Cultures of $N$. tenuis and $M$. pygmaeus were maintained in climatic chamber at $25 \pm 2{ }^{\circ} \mathrm{C}, 60-80 \% \mathrm{RH}$ and 16:8 $\mathrm{h}(\mathrm{L}: \mathrm{D})$ photoperiod $25 \pm 2{ }^{\circ} \mathrm{C}, 60-80 \% \mathrm{RH}$ and 16:8 h (L:D) photoperiod at IVIA. Both mirid cultures were separately caged on sweet pepper plants with access to Ephestia kuehniella Zeller (Lepidoptera: Pyralidae) eggs (Entofood $® ;$ Koppert B.S.) as supplemented food until their use in the bioassays. Five day old adult $N$. tenuis and M. pygmaeus were used in 
all the experiments. Newly emerged adult B. tabaci (less than 2 day old) were similarly reared on sweet pepper plants caged in $60 \times 60$ × 60-cm BugDorm-2 insect tents. In the case of E. formosa, pupae were enclosed in a Petri dish ( $9 \mathrm{~cm}$ diameter) and allowed to emerge under ambient laboratory conditions $\left(25 \pm 2{ }^{\circ} \mathrm{C}\right)$, with a small drop of honey provided as food. Females E. formosa were used at less than two days old all experiments.

Frankliniella occidentalis adults were obtained from a culture established at IVIA in 2010, originally collected from Campo de Cartagena (Murcia, Spain). The thrips culture was maintained on bean plants (Phaseolus vulgaris L.; Fabales: Fabaceae) and housed in a climatic chamber at $25 \pm 2{ }^{\circ} \mathrm{C}, 65 \pm 10 \% \mathrm{RH}$ and a 14:10 h (L:D) photoperiod at IVIA. All female F. occidentalis used for experimentation were less than five days old.

\subsubsection{Mirid behaviour on sweet pepper}

Direct observations for both male and female $N$. tenuis and M. pygmaeus behaviour were carried out on intact sweet pepper plant for 30 minutes under a hand magnifying glass ( $5 \mathrm{~cm}$ of diameter and a magnification of $2.5 \mathrm{x}-5 \mathrm{x}$ ) (Entomopraxix, Barcelona, España). The experimental arena consisted an intact sweet pepper plant inside a plastic cage $60 \times 60$ × 60-cm (BugDorm-2 insect tents), ( $\mathrm{T}=25 \pm 2{ }^{\circ} \mathrm{C}, \mathrm{RH}=60-80 \%$ ). A single mirid predator (male or female) was then released onto the plant. Recording began when the first behavioural activity was observed (typically: walking, though any of the other recorded behaviours were also considered). Duration of each behaviour and the corresponding location on the plant was noted. For each assay (species and sex), twenty replications were carried out and the sweet pepper plant replaced by new intact plant for each of the subsequent observations. 
Observed behaviours were the following: Walking (W): Predator walking behaviour on the different regions of the plant. Antennating (A): Stationary searching activity, characterised by moving the antennae. Walking-Antennating (W-A): Non-stationary searching activity characterised by moving the antennae and walking. Feeding $(\mathrm{F})$ : The predator uses labium to probe the feeding sites and then inserts the stylet vertically into the plant. Oviposition $(\mathrm{O})$ : The predator firstly probes the oviposition site with the labium, then the whole abdomen is pressed onto the plant and the length of the ovipositor inserted into the plant, egg deposition is visible. Grooming (G): Cleaning mouthparts with forelegs and/or cleaning another part of the body. Flying (Fl): Flying movement typically from the plant to the cage walls or the opposite. Resting (R): The predator is at rest, stationary and not carrying out any other described behaviour.

The plant locations visited by the predator during the observation were defined. One location off-plant (plastic cage, plastic pot or soil) and two locations on-plant (apical region and basal region) were defined. The apical region of sweet pepper plant was defined as the first $5 \mathrm{~cm}$ of the plant formed by apical stem, young developing leaves and 2 fully developed leaves. The basal region was the rest of the plant, approximately $10-12 \mathrm{~cm}$ with 4 developed leaves, basal stem and cotyledons.

\subsubsection{Phytohormone analysis and plant gene expression}

In order to identify the phytohormone profile of 1) N. tenuispunctured plants, 2) M. pygmaeus-punctured plants and 3) sweet pepper intact plants, the hormones, abscisic acid (ABA), salicylic acid (SA), jasmonic acid (JA) and JA-isoleucine (JA-Ile) were analysed by ultra-performance 
liquid chromatography coupled with mass spectrometry (UPLC-MS) (Flors et al., 2008, Forcat et al., 2008; Pérez-Hedo et al., 2015a).The apical region of the pant, as defined previously, from each treatment was removed and stored at $-80 \stackrel{\circ}{\circ}$ until analysis. Five replicates were collected for each treatment. Analyses were carried out using an Acquity ultra-performance liquid chromatography system (UPLC; Waters, Mildford, MA, USA) and the chromatograph interfaced to a triple quadrupole mass spectrometer (TQD, Waters, Manchester, UK). MassLynx NT software version 4.1 (Micromass) was used to process the quantitative data from calibration standards and the plant samples. The calibration curves were obtained by using solutions containing increasing amounts of ABA, SA, JA and JA-Ile commercial standards (Sigma-Aldrich, http://www.sigma-aldrich. com).

Expression of (i) ASR1 (abscisic acid stress ripening protein 1) a marker gene for ABA, (ii) PIN2 (wound-induced proteinase inhibitor II precursor) a marker gene for JA, and (iii) PR1 (basic PR-1 protein precursor) a marker gene for the SA signalling pathway, were quantified for each of the three plant treatment samples taken from the apical region of the sweet pepper plants. Samples were cut and then ground in liquid nitrogen and a portion used for RNA extraction. Total RNA $(1.5 \mu \mathrm{g})$ was extracted using Trizol (Invitrogen, CA, USA) according to the manufacturer's instructions (Pérez-Hedo et al., 2015a; Naselli et al., 2016). Samples were homogenized with TRIzol ${ }^{\mathrm{TM}}$ Reagent and then chloroform was added to separate protein RNA and DNA. RNA was precipitated with the addition of isopropanol and $1.2 \mathrm{Mm} \mathrm{NaCl}$. After quantification, the RNA was treated with the Turbo DNA-free DNase kit (Applied Biosystems) to eliminate any traces of genomic DNA, according to the manufacturer's protocol. cDNA was then synthesized using prime script ${ }^{\mathrm{TM}} \mathrm{RT}$ reagent kit (perfect real time) 
(TAKARA Bio, CA, USA). The reaction mixture was then incubated in the thermo-cycler for $15 \mathrm{~min}$ at $37^{\circ} \mathrm{C}$ followed by $5 \mathrm{~s}$ at $85{ }^{\circ} \mathrm{C}$. Real-time PCR amplifications were performed with Maxima SYBR Green qPCR Master Mix (Thermo Fisher Scientific, MA, USA). Capsicum annuum specific forward and reverse primers $(0.5 \mu \mathrm{l})$ were designed and added to $5 \mu \mathrm{l}$ of Syber green/ROX qPCR MM and $1 \mu \mathrm{l}$ of cDNA and then brought to $10 \mu \mathrm{l}$ total volume with Milli-Q sterile water. PCR reactions were run in duplicate, in accordance with manufacturer recommendations. Quantitative PCR was carried out using the LightCycler® 480 System (Roche Molecular Systems, Inc., Switzerland), under the following amplification conditions, $95{ }^{\circ} \mathrm{C}$ for $10 \mathrm{~min}$ followed by 40 cycles of $95{ }^{\circ} \mathrm{C}$ for $15 \mathrm{~s}, 56{ }^{\circ} \mathrm{C}$ for $30 \mathrm{~s}$ and $72{ }^{\circ} \mathrm{C}$ for $30 \mathrm{~s}$. Melting curve analysis was performed at $95^{\circ} \mathrm{C}$ for $5 \mathrm{~s}, 60^{\circ} \mathrm{C}$ for $1 \mathrm{~min}$ and then a continuous increase of temperature up to $95^{\circ} \mathrm{C}$ to finalise the process. Data acquisition and calculation were performed with the thermal cycler's software and were then collected and analysed in Microsoft Excel. Each qPCR data point is the average of 8 independent experiments. EF1 (elongation factor-1) was used as a standard control gene for normalization. The nucleotide sequences of the gene specific primers are the same used in chapter 2 (Table 2.1).

\subsubsection{Determination of plant volatile compounds}

Volatile compounds emitted from 1) N. tenuis-punctured sweet pepper plants, 2) M. pygmaeus-punctured plants and 3) intact plants were collected using $5 \mathrm{~L}$ volume glass jars as used in Y-tube olfactometer described below (Analytical Research Systems, Gainesville, FL) (Pérez Hedo and Urbaneja, 2015). One sweet pepper plant was introduced (either intact or mirid-punctured) into each jar. After closing the jar, an adsorbent-coated 
SPME fibre (PDMS/DVB (65 $\mu \mathrm{m}$ polydimethylsiloxane/Divinylbenzene; Supelco, Bellefonte, PA, USA) was mounted on the fibre holder, and injected through the first septum (top of the jar). Agitation of the atmosphere inside the container was achieved by pumping at $5 \mathrm{ml} / \mathrm{min}$ using a syringe injected through the second septum (bottom of the jar). The three jars were maintained in the Y-tube olfactometer table at a light intensity of $2516 \mathrm{~lx}$. The volatiles emitted were captured over a 3 hours period, and 5 replicates per treatment were performed. After collection, the fibre was retracted into the needle and the SPME device was removed from the container. The compounds absorbed in the SPME fibre were separated and detected by means of GC-MS.

Desorption was performed by means of a CombiPAL autosampler (CTC Analytics) at $250{ }^{\circ} \mathrm{C}$ for a duration of $1 \mathrm{~min}$ in splitless mode in the injection port of a $6890 \mathrm{~N}$ gas chromatograph coupled to a $5975 \mathrm{~B}$ mass spectrometer (Agilent Technologies). To prevent cross-contamination, fibres were cleaned after desorption in an SPME fibre conditioning station (CTC Analytics) at $250{ }^{\circ} \mathrm{C}$ for $5 \mathrm{~min}$ under helium flow. Chromatography was performed on a DB-5ms $(60 \mathrm{~m}, 0.25 \mathrm{~mm}, 1.00 \mu \mathrm{m})$ column with helium as carrier gas at a constant flow of $1.2 \mathrm{ml} / \mathrm{min}$. GC interface and MS source temperatures were $260{ }^{\circ} \mathrm{C}$ and $230{ }^{\circ} \mathrm{C}$ respectively. Oven programming conditions were $40{ }^{\circ} \mathrm{C}$ for $2 \mathrm{~min}, 5^{\circ} \mathrm{C} / \mathrm{min}$ ramp until $250{ }^{\circ} \mathrm{C}$, and a final hold at $250{ }^{\circ} \mathrm{C}$ for $6 \mathrm{~min}$. Data were recorded in the $35-300 \mathrm{~m} / \mathrm{z}$ range at 5 scans/s, with electronic impact ionization at $70 \mathrm{eV}$. Untargeted analysis of the chromatograms was performed by means of the MetAlign software (WUR, http://www.metalign.nl).

Kovats retention indices (KI) were calculated for each of the compounds. Differentially emitted volatiles were first tentatively identified by comparing their mass spectra with those in the NIST 05 Mass Spectral 
Library. When available, identity was confirmed by coelution with the pure standards (Sigma-Aldrich). For quantitation of the selected compounds, one specific ion was selected for each compound, and the corresponding peak area from the extracted ion chromatogram was integrated by means of the ChemStation E.02.02 software (Agilent Technologies). The criteria for ion selection were the highest signal-to-noise ratio and being specific enough in that particular region of the chromatogram in order to provide good peak integration.

\subsubsection{Response to induced sweet pepper plants}

The olfactory response of the sweet pepper pests F. occidentalis and B. tabaci and the whitefly parasitoid E. formosa, to both mirid punctured plants and intact plants was firstly investigated in the Y-tube olfactometer. The Y-tube olfactometer consisted of two $5 \mathrm{~L}$ volume jars connected with a $2.4 \mathrm{~cm}$ diameter Y-shaped glass tube (Pérez-Hedo and Urbaneja, 2015), with a 13.5-cm long base and two arms each $5.75 \mathrm{~cm}$ long. Both side arms were connected via high density polyethylene (HDPE) tubes to the two identical glass jars. Each glass jar was connected to an air pump that produced a unidirectional humidified airflow at $150 \mathrm{~mL} \mathrm{~min}^{-1}$ (Pérez-Hedo and Urbaneja, 2015). Four 60-cm fluorescent tubes (OSRAM, L18W/765, OSRAM GmbH, Germany) were positioned $40 \mathrm{~cm}$ above the horizontal Y-shaped glass tube. The light intensity registered 2,516 lux over the Y-tube and was measured using a ceptometer (LP-80 AccuPAR, Decagon Devices, Inc. Pullman, WA, USA). All Y-tube experiments were conducted under the following environmental conditions, $23 \pm 2{ }^{\circ} \mathrm{C}, 60 \pm 10 \% \mathrm{RH}$. 
In the entrance of the Y-tube we individually introduced each of the tested females of either B. tabaci, F. occidentalis or E. formosa. The result of the choice test was only recorded once the female had walked at least $3 \mathrm{~cm}$ up one of the arms or the assay was terminated after 15 minutes had elapsed and excluded from the data analysis. A total of 30-40 valid replicates from each species were recorded for each pair of odour sources. For each 5 collected responses the Y-tube was rinsed with soap, water and acetone and then left for 5 minutes to dry. Odour sources were switched between the left and right side arms to minimize any spatial effect on choice. All test plants were replaced after recording 10 responses.

To confirm the Y-tube observation a second choice experiment was conducted using 16 plastic cages $(60 \times 60 \times 60 \mathrm{~cm})$ (BugDorm-2 insect tents) maintained in a climatic chamber at $25 \pm 2{ }^{\circ} \mathrm{C}, 60-80 \% \mathrm{RH}$ and $14: 10 \mathrm{~h}$ (L:D) photoperiod. Inside each cage, three intact plants and three mirid-punctured plants (either by N. tenuis or M. pygmaeus) were arranged alternately in a circle. One hundred F. occidentalis or 100 B. tabaci adults were released separately in the centre of the circle of plants. Frankliniella occidentalis and B. tabaci were allowed to freely forage within the cage for 24 hours, the number on each plant treatment group (intact or mirid-punctured) were counted. The experiment was replicated four times for both F. occidentalis and B. tabaci to test their response to $N$. tenuis-punctured plants and $M$. pygmaeus-punctured plants.

\subsubsection{Persistence of plant induction}

In the Y-tube olfactometer we evaluated the persistence of the attraction or antixenosis induced by $N$. tenuis in order to induce indirect defences. The response of B. tabaci and E. formosa were tested at 4, 7 and 
14 days after exposure to $N$. tenuis. Twenty-four hours after activation, $N$. tenuis adults were removed and punctured plants were left in enclosed plastic cages $(30 \times 30 \times 30 \mathrm{~cm})$ (BugDorm-1 insect tents) where the experiment was conducted. A total of 30 responses were recorded.

RNA extraction and gene expression (ASR1, PIN2 and PR1) (Table 2.1; Chapter 2) was conducted to confirm Y-tube results. Eight apical regions from intact plants and from $N$. tenuis-punctured plants were collected. The same protocol as described above for quantitative PCR reaction was followed. According to the olfactometer results, the relative expression of defensive genes was performed 14 days after exposure to $N$. tenuis in comparison to intact plants.

\subsubsection{Statistical analysis}

Mirid behaviour on sweet pepper was analysed using two-way analysis of variance (ANOVA) to differentiate between predator species and sex, followed by comparison of means (Bonferroni post-tests) at $\alpha<0.05$. One-tailed Student's $t$-test $(P<0.05)$ was performed to compare oviposition behaviour between the two mirid species. To compare between intact plants, N. tenuispunctured plants and M. pygmaeus-punctured plants, the volatile profile from mirid-punctured plants and intact plants, phytohormone profile and defensive gene expressions were normalized using a logarithmic transformation and then analysed using a one way analysis of variance (ANOVA), followed by comparison of means (Tukey's test) at $\alpha<0.05$. In the no-choice experiment, the number of thrips and whiteflies was compared between intact plant assays and mirid-punctured plant assays using a one-tailed Student's $t$-test $(P<0.05)$. To evaluate the persistence of plant defence induction, a one tailed $t$-test 
$(P<0.05)$ was performed to compare the quantified expression of defensive genes between intact plants and $N$. tenuis-punctured-plants over the time increments. Chi-square $\left(\chi^{2}\right)$ goodness of fit tests based on a null model were used to analyse data collected from the olfactory responses where the odour sources were selected with equal frequency. Individuals which did not make a choice were excluded from the statistical analysis. Results were expressed as the mean \pm standard error.

\subsection{Results}

\subsubsection{Mirid behaviour on sweet pepper}

Both mirid species were found to spend the most time feeding on the plant (Table 3.1), with $N$. tenuis spending significantly more time feeding than $M$. pygmaeus $\left(F_{1,76}=22.37, P<0.0001\right)$. Feeding behaviour between the sexes was not significantly different $\left(F_{1,76}=0.09, P=0.75\right)$. However, a significant interaction between sex and species was found $\left(F_{1,76}=4.57, P=0.03\right)$ with $N$. tenuis males tending to feed on the plant for a longer duration than females, whereas the contrary was observed for M. pygmaeus. Time duration of walking activity was higher for $M$. pygmaeus than that of $N$. tenuis $\left(F_{1,76}=8.46\right.$, $P=0.0048$ ) and males of both species spent significantly more time walking than females $\left(F_{1,76}=9.137, P=0.0034\right)$. In contrast, females of both species spent significantly more time walking-antennating (walking accompanied by exploratory behaviour of the antennae) than males $\left(F_{1,76}=4.034, P=0.0481\right)$, with no significant differences between species observed $\left(F_{1,76}=1.55, P=0.22\right)$. For all other observed behaviours (antennating, grooming and flying), both 
mirid species and sexes behaved similarly, with no significant difference observed (Table 3.1 and Table S1).

Residency on different plant localities was found to vary between species. Nesidiocoris tenuis was found to spend a significantly longer duration of time in the apical region of the sweet pepper plant than M. pygmaeus $\left(F_{1,76}=6.80, P=0.01\right)$, while the opposite occurred in the basal region $\left(F_{1,76}=4.7\right.$, $P=0.03)$. No differences were found in residency between the sexes either in the apical $\left(F_{1,76}=3.739, P=0.05\right)$ or in the basal regions $\left(F_{1,76}=0.80, P=0.37\right)$. Males of both species remained for significantly longer time periods off-plant than the females $\left(F_{1,76}=4.75, P=0.03\right)$ with no significant difference observed in time spent off-plant between the two mirid species $\left(F_{1,76}=6.21, P=0.01\right)$ (Table 3.1).

\section{Table 3.1.}

Time in seconds (mean \pm SE) spent by males and females of $N$. tenuis and M. pygmaeus in eight different behavioural states on sweet pepper plant, and the resident time (mean $\pm \mathrm{SE}$ ) of each predator on the three designed locations. Observation were performed during 30 minutes.

\begin{tabular}{rcccc}
\cline { 2 - 5 } & \multicolumn{2}{c}{ Nesidiocoris tenuis } & \multicolumn{2}{c}{ Macrolophus pygmaeus } \\
\hline Behaviours & Female $(\mathrm{n}=20)$ & Male $(\mathrm{n}=20)$ & Female $(\mathrm{n}=20)$ & Male $(\mathrm{n}=20)$ \\
\hline Grooming & $105.1 \pm 25.7 \mathrm{~A}$ & $72.5 \pm 27.3 \mathrm{~A}$ & $72.7 \pm 28.5 \mathrm{~A}$ & $31.8 \pm 11.2 \mathrm{~A}$ \\
\hline Feeding & $492.0 \pm 74.1 \mathrm{~A}$ & $660.6 \pm 86.9 \mathrm{~A}$ & $313.8 \pm 74.1 \mathrm{~B}$ & $187.9 \pm 46.7 \mathrm{~B}$ \\
\hline Flying & $2.3 \pm 1.0 \mathrm{~A}$ & $4.4 \pm 2.0 \mathrm{~A}$ & $2.5 \pm 1.5 \mathrm{~A}$ & $5.4 \pm 1.8 \mathrm{~A}$ \\
\hline Ovipositing & $28.4 \pm 10.5 \mathrm{~A}$ & - & $78.6 \pm 30.4 \mathrm{~A}$ & - \\
\hline Resting & $504.9 \pm 51.2 \mathrm{~A}$ & $555.6 \pm 34.9 \mathrm{~A}$ & $605.4 \pm 106.3 \mathrm{~A}$ & $728.3 \pm 105.1 \mathrm{~A}$ \\
\hline Antennating & $144.3 \pm 41.5 \mathrm{~A}$ & $90.6 \pm 24.0 \mathrm{~A}$ & $270.6 \pm 76.0 \mathrm{~A}$ & $175.3 \pm 59.8 \mathrm{~A}$ \\
\hline Walking & $84.6 \pm 20.7 \mathrm{~B}$ & $201.2 \pm 49.8 \mathrm{~B}^{*}$ & $193.6 \pm 45.3 \mathrm{~A}$ & $483.8 \pm 114.7 \mathrm{~A}$ \\
\hline Walk.- Antenn. & $338.0 \pm 66.4 \mathrm{~A}$ & $186.5 \pm 62.6 \mathrm{~A}^{*}$ & $231.7 \pm 63.6 \mathrm{~A}$ & $145.6 \pm 40.3 \mathrm{~A}$ \\
\hline Locations & & & & \\
\hline Apical region & $1407 \pm 114.4 \mathrm{~A}$ & $1232 \pm 159.7 \mathrm{~A}$ & $1134 \pm 149.8 \mathrm{~B}$ & $749.7 \pm 150.4 \mathrm{~B}$ \\
\hline Basal region & $154.7 \pm 83.4 \mathrm{~B}$ & $185.6 \pm 89.9 \mathrm{~B}$ & $482.2 \pm 131.7 \mathrm{~A}$ & $321.7 \pm 113.5 \mathrm{~A}$ \\
\hline Outside & $132.7 \pm 85.2 \mathrm{~A}$ & $346.3 \pm 117.5 \mathrm{~A}^{*}$ & $136.6 \pm 68.7 \mathrm{~A}$ & $677.3 \pm 167.8 \mathrm{~A}$ \\
\hline
\end{tabular}

Values followed by different letters and ${ }^{*}$ in each row were significantly different between predator species and sexes, respectively (ANOVA $P<0.05$ ) 


\subsubsection{Mirids impact both $A B A$ and JA signaling pathways}

The feeding behaviour of both mirid predators significantly altered the hormonal profile of sweet pepper plants (Fig.3.1). Nesidiocoris tenuis and M. pygmaeus feeding behaviour significantly increased the levels of ABA, JA and JA-Ile when compared to intact plants $\left(F_{2,14}=20.27, P<0.0001\right.$ for ABA; $F_{2,14}=20.14$; $P<0.0001$ for JA; $F_{2,14}=9.36 ; P=0.004$ for JA-Ile) (Figs.3.1.a, c, d). Furthermore, the level of ABA was significantly higher following inoculation with $N$. tenuis which may suggest a higher impact on plant's metabolism than M. pygmaeus feeding behaviour. In the case of SA, plants punctured by feeding behaviour of either mirid species displayed increased concentrations of this hormone, but these differences were not significantly different between species $\left(F_{2,14}=3.26 ; P=0.074\right)$.

(a)

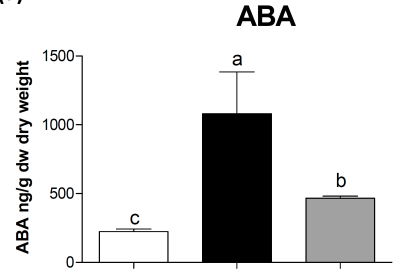

(c)

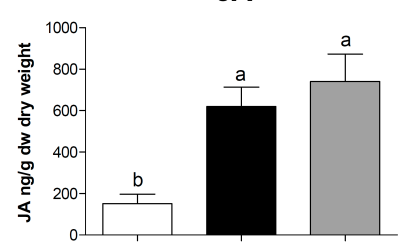

$\square$ Intact plants (b)

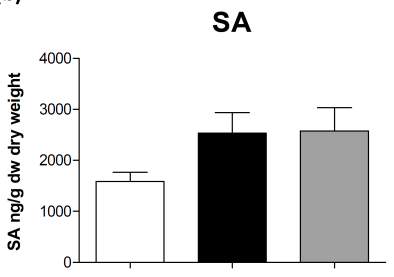

(d)

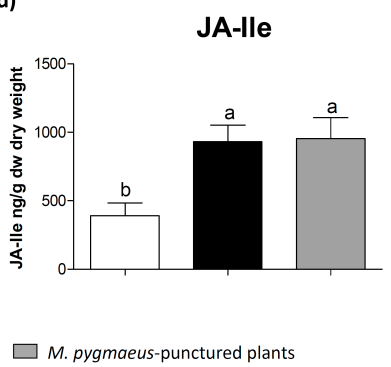

Figure 3.1.

Comparison between the phytohormone levels in the apical regions of intact sweet pepper plants, $N$. tenuis-punctured plants and M. pygmaeus-punctured plants, (a) ABA, (b) SA, (c) JA and (d) JA-lle. The presented results are the mean hormone level of five independent analyses $\pm S E(n=5)$. Bars with different letters are significantly different (ANOVA, Tukey's multiple comparison test $\alpha<0.05$ ). 
The quantification of ASR1, PIN2 and PR1 gene expression displayed upregulation of the $A S R 1$ and PIN2 genes in plants punctured by either mirid species $\left(F_{2,21}=10.10, P=0.001\right.$ for $A S R 1$ and $F_{2,21}=15.27, P=0.0005$ for PIN2), whereas only $N$. tenuis was able to upregulate the gene PR1 $\left(F_{2,21}=10.29\right.$; $P=0.0017$ ) (Fig.3.2) when compared with the intact sweet pepper plants.

(a)

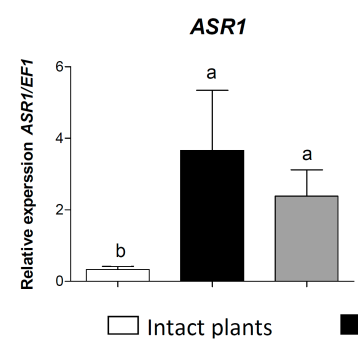

(b)

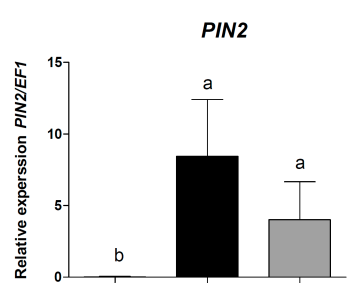

(c)

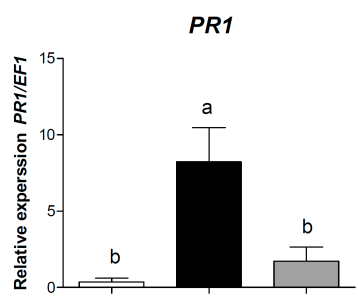

N. tenuis-punctured plants

M. pygmaeus-punctured plants

Figure 3.2.

Quantification of defensive genes in the apical regions of intact sweet pepper plants, N. tenuis-punctured plants and M. pygmaeus-punctured plants, (a) ASR1, (b) PIN2 and (c) PR1. Data are presented as the mean of eight independent analyses of transcript expression relative to a housekeeping gene $\pm S E(n=8)$. Bars with different letters are significantly different (ANOVA, Tukey's multiple comparison test $a<0.05$ ).

3.3.3. Mirids significantly altered the volatile blend following inoculation

The untargeted analysis of the volatiles emitted by the tomato plants facilitated the identification of 14 compounds differentially emitted between mirid-punctured and intact plants (Table 3.2) based on their mass spectra and coelution with pure standards, when available. Compounds were identified as terpenoids ( 2 monoterpenoids, 3 sesquiterpenoids and 1 norisoprenoid), 
green leaf volatiles (5 esters ((Z)-3-hexenyl acetate, $(Z)$-3-hexenyl propanoate, (Z)-3-hexenyl butanoate, (Z)-3-hexenyl 3-methylbutanoate and (Z)-3-hexenyl benzoate) and their common precursor (Z)-3-hexenol), and two further compounds methyl salicylate and octyl acetate. Octyl acetate was only detected in M. pygmaeus punctured plants (Table 3.2). All of the identified compounds showed significantly increased emission in punctured plants when compared to intact, ranging from 9-fold to 130-fold.

3.3.4. Mirid infestation triggers parasitic wasp attraction and induces pest antixenosis

In the Y-tube olfactometer, the phytophagous species F. occidentalis and B. tabaci displayed a significant positive response towards the odour source emitted by intact sweet pepper plants when compared to either $N$. tenuispunctured plants $\left(\chi^{2}=10.90 ; P=0.001\right.$ and $\chi^{2}=6.67 ; P=0.0098$, respectively) or M. pygmaues punctured plants $\left(\chi^{2}=10.45 ; P=0.0012\right.$ and $\chi^{2}=10.45 ; P=0.0012$, respectively) (Fig.3.3.a, b). In contrast, E. formosa displayed a significant attraction towards the sweet pepper plants punctured by $N$. tenuis $\left(\chi^{2}=6.48\right.$; $P=0.01)$ and $M$. pygmaeus $\left(\chi^{2}=11.08 ; P=0.0009\right)$ relative to intact plants (Fig.3.3). 
Induced Defences by Mirids in Sweet Pepper

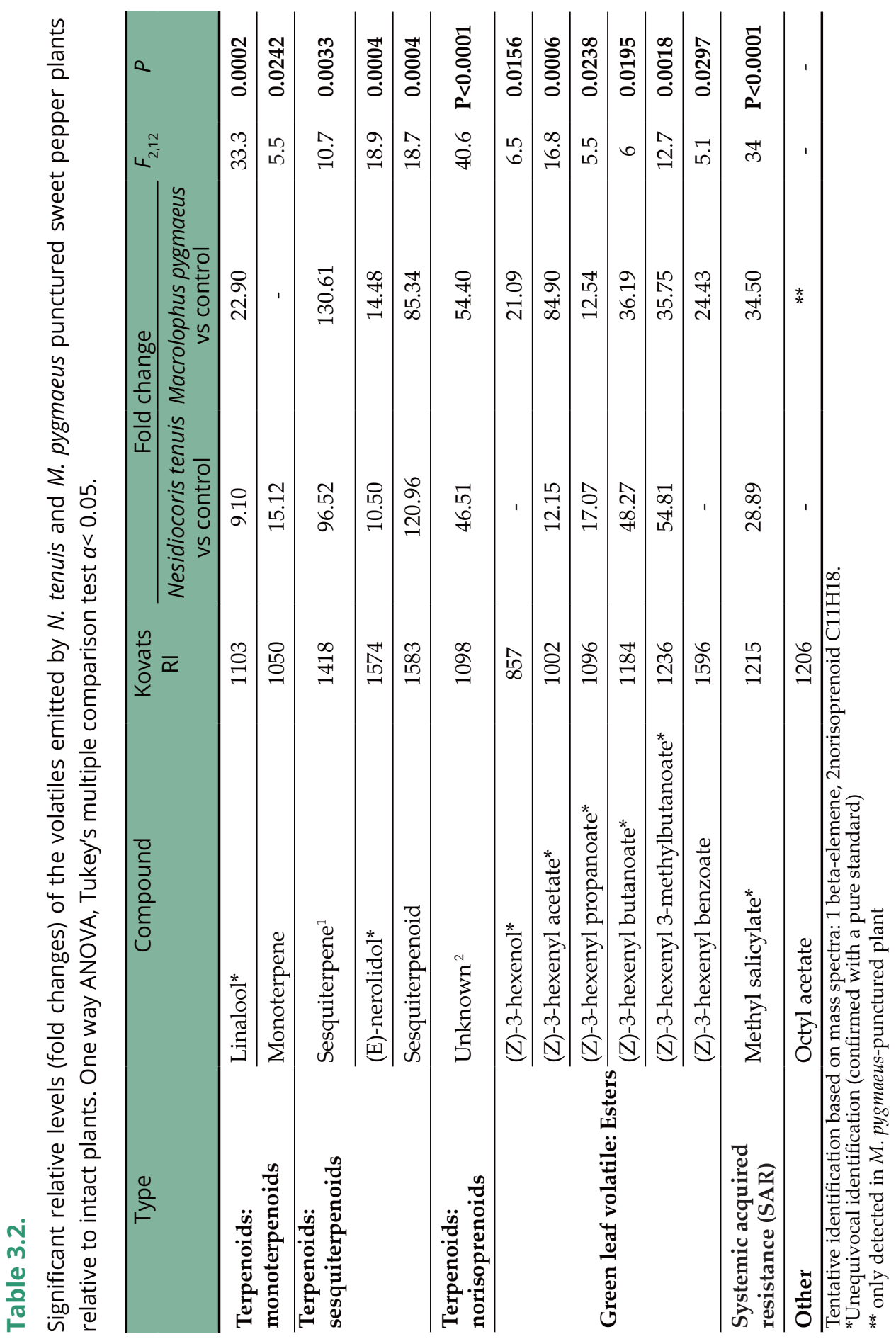


(a)
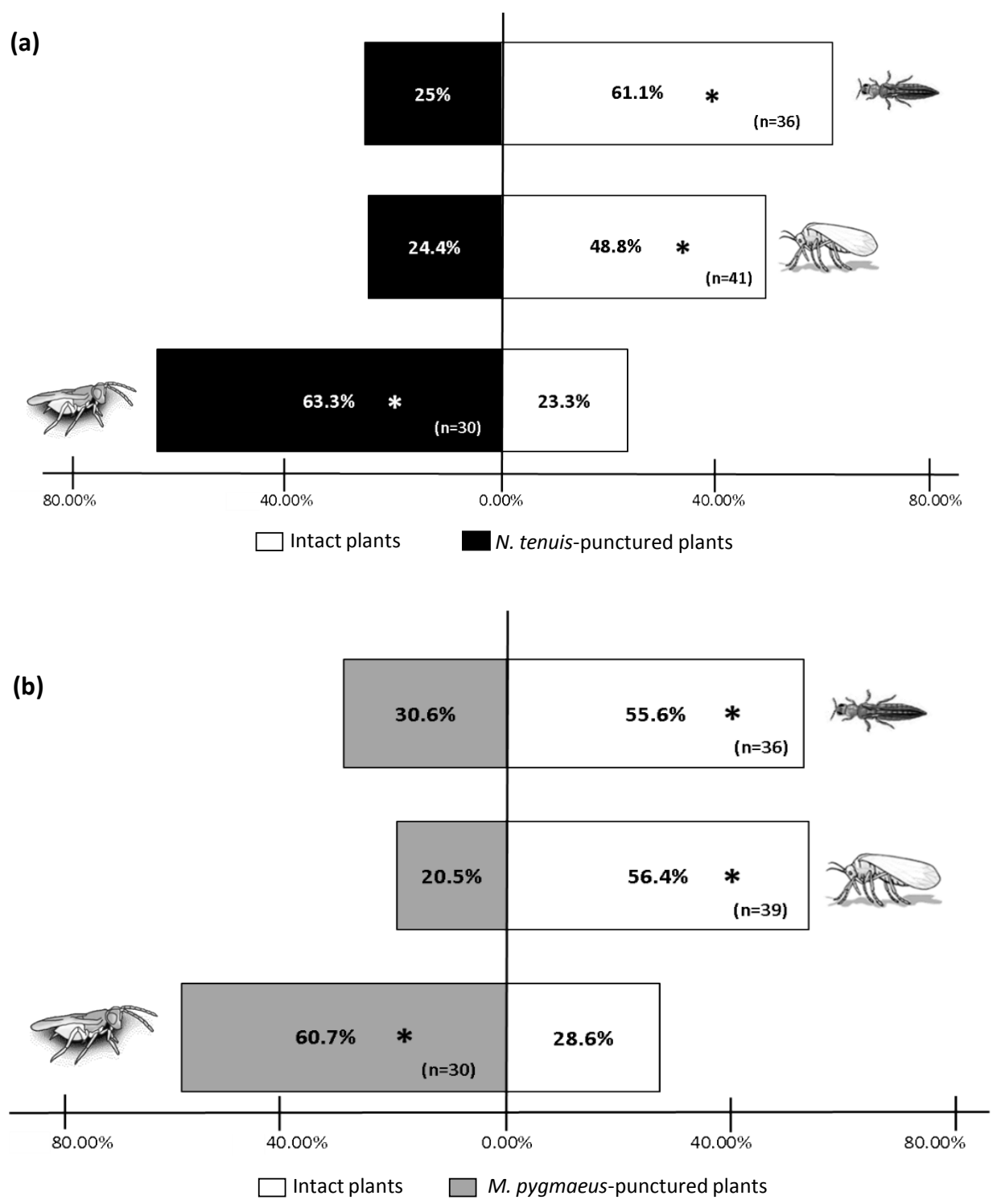

Figure 3.3.

Olfactory response of the selected insects to mirids-punctured plants in comparison to intact plants. (a) Response of $F$. occidentalis $(\mathrm{n}=36), B$. tabaci $(\mathrm{n}=41)$ and $E$. formosa $(\mathrm{n}=30)$ in the $Y$-tube olfactometer when exposed to intact sweet pepper plants and $N$. tenuis-punctured plants. (b) Response of $F$. occidentalis $(n=36), B$. tabaci $(n=39)$ and E. formosa $(n=30)$ in the $Y$-tube olfactometer when exposed to intact sweet pepper plants and $M$. pygmaeus-punctured plants. Significant differences based on a $\chi 2$-test are marked using * $(P<0.05)$. 
In the cage experiments containing both $N$. tenuis punctured and intact plants a significantly lower number of F. occidentalis $(t=5.55 ; P=0.0007)$ and $B$. tabaci $(t=3.60 ; P=0.006)$ were found on $N$. tenuis-punctured plants than the control plants. In cage experiments containing M. pygameus-punctured plants and intact plants, again significantly lower numbers of F. occidentalis and $B$. tabaci individuals were found on $M$. pygmaeus-punctured plants ( $t=5.07 ; P=0.0011 ; t=5.68 ; P=0.0006$, respectively) (Figs.3.4.a, b).
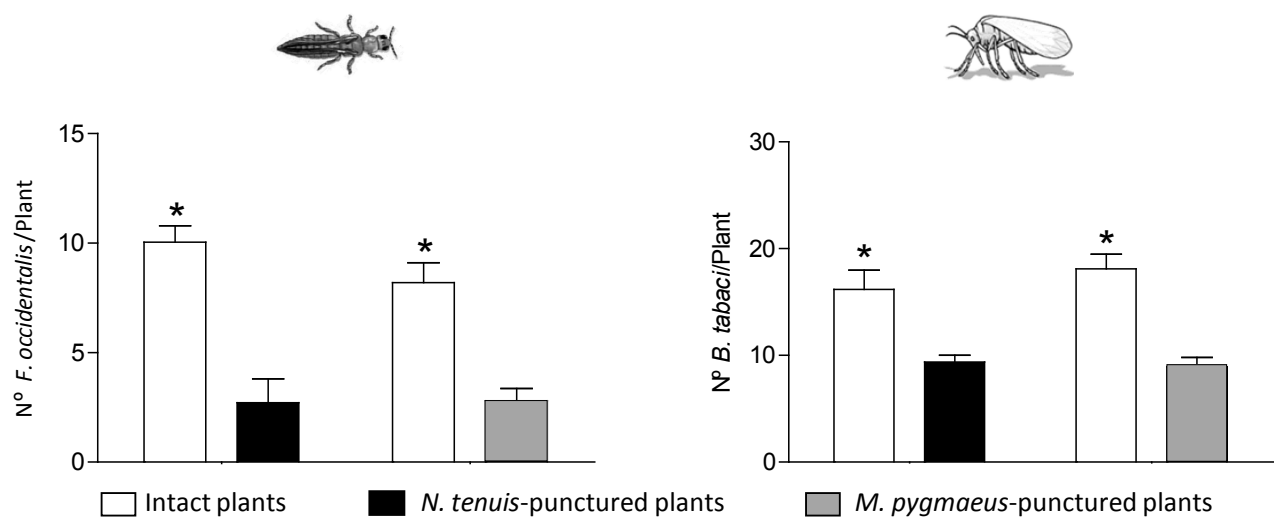

\section{Figure 3.4.}

Herbivores choice between mirid punctured plants and intact plants. (a) Number of F. occidentalis adults per plant $(\mathrm{X} \pm \mathrm{SE}$ ) captured 24 hours after releasing $100 \mathrm{~F}$. occidentalis in the centre of a cage containing 3 intact plants and $3 \mathrm{~N}$. tenuis/M. pygmaeus-punctured plants. (b) Number of $B$. tabaci adults per plant $(\mathrm{X} \pm \mathrm{SE}$ ) captured 24 hours after releasing 100 B. tabaci in the centre of a cage containing 3 intact plants and 3 N. tenuis/M. pygmaeuspunctured plants. Both mirid species were in contact with the plants only $24 \mathrm{~h}$ and then removed. Significant difference resulting from a one tailed $t$-test are marked with $\left(^{*}\right)$ $(P<0.05)$. 
3.3.5. Indirect defences triggered by N. tenuis last for several weeks

The parasitoid, E. formosa, was significantly attracted to N. tenuispunctured plants which were previously activated by the mirid, $N$. tenuis, 4,7 and 14 days before $\left(\chi^{2}=9.60 ; P=0.0019 ; \chi^{2}=6.25 ; P=0.0124 ; \chi^{2}=4.27\right.$; $P=0.04$ for 4,7 and 14 days, respectively). In contrast, the phytophagous pest species $B$. tabaci was significantly repelled to $N$. tenuis-punctured plants, but only those plants activated 4 and 7 days before $\left(\chi^{2}=9.80 ; P=0.0017\right.$; $\chi^{2}=4.27 ; P=0.04$, respectively). This repellent effect was not observed at day 14, where both plant treatments induced similar attraction response in B. tabaci $\left(\chi^{2}=0.26 ; P=0.60\right)$ (Fig. 3.5.a). The relative expression of the genes ASR1, PIN2 and PR1 quantified at day 14 after activation showed that the three genes were upregulated in $N$. tenuis-punctured plants when compared to intact plants $(t=4.51, P=0.004 ; t=4.101, P=0.006$ for ASR1, PIN2 and PR1, respectively) (Fig. 3.5.b). 
(a)

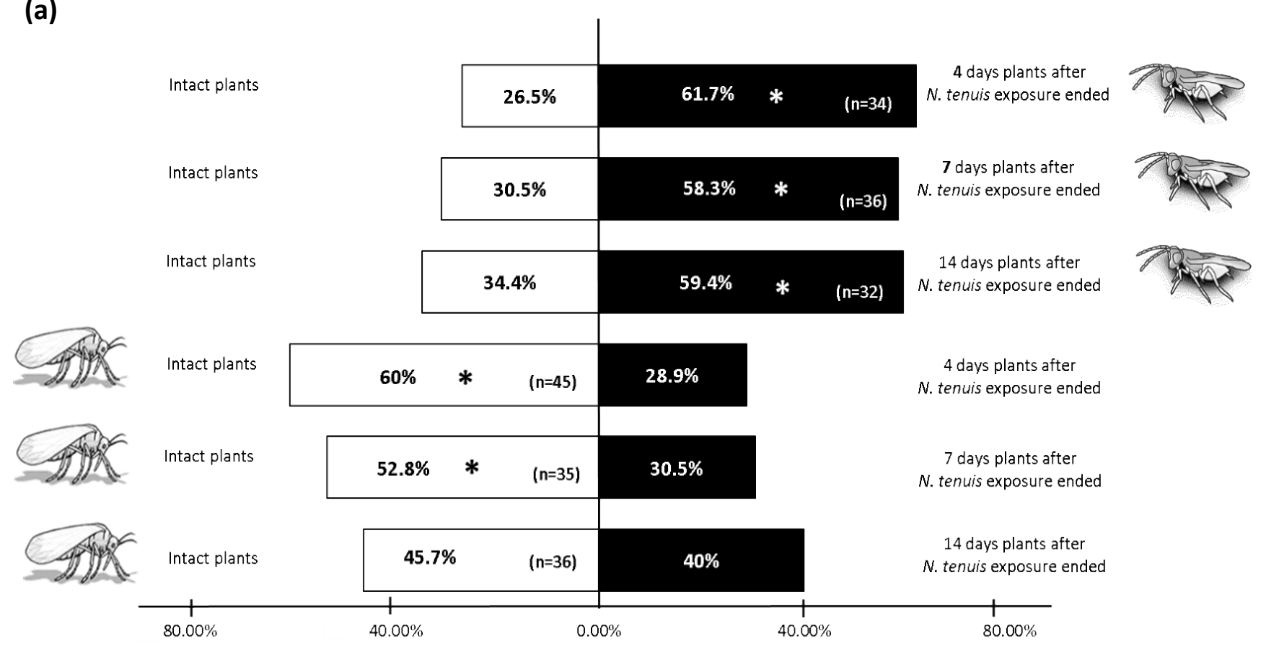

(b)
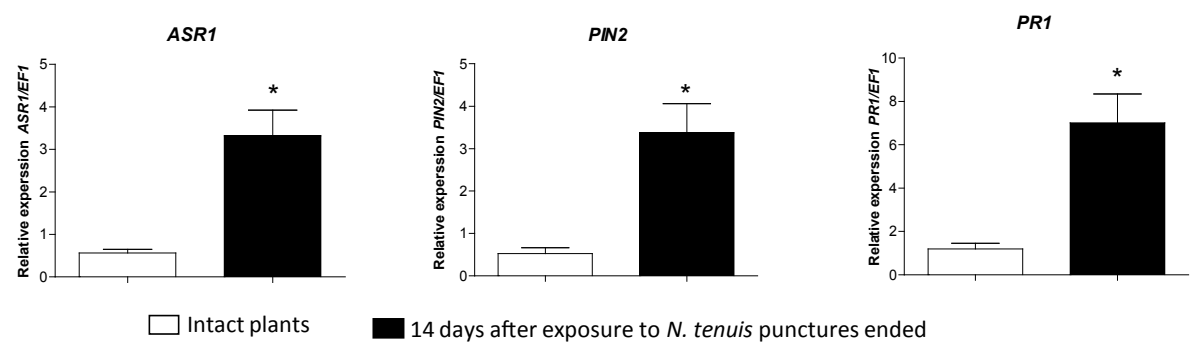

14 days after exposure to $N$. tenuis punctures ended

\section{Figure 3.5.}

Persistence of sweet pepper induction following $N$. tenuis punctures. (a) Response of E. formosa and B. tabaci, respectively to $N$. tenuis-punctured plants vis intact plants after 4 days, 7 days and 14 days exposure ended. Significant differences based on a $\chi^{2}$-test are marked using * $(P<0.05)$. (b) Relative expression of defensives genes ASR1, PIN2 and $P R 1$ in intact sweet pepper plants with comparison to $N$. tenuis-punctured plants, 14 days after exposure ended. Data are presented as the mean of eight independent analyses of transcript expression relative to the constitutive $E F 1$ gene $\pm S E(n=8)$. Significant difference from a one tailed $t$-test are marked with $\left(^{*}\right)(P<0.05)$. 


\subsection{Discussion}

In this study, feeding activity by the zoophytophagous mirid predators, $N$. tenuis and M. pygmaeus has been shown to induce defensive responses in sweet pepper plants for the first time. Both predatory mirid species spent significantly more time feeding than any other activity on sweet pepper plant, an important behaviour known to facilitate establishment of the predator in the crop and maintain a population in periods of prey scarcity (Perdikis and Lykouressis, 2000; Urbaneja et al., 2005). When released after 24 hours of starvation, (Montserrat et al., 2000; Durate et al., 2014) N. tenuis feeding behaviour was observed at 33\% of total observed activity, more than double that of $M$. pygmaeus (14\%). Both species displayed a preference for feeding on the apical region of the sweet pepper plant, though the strongest preference was observed in N. tenuis, with $93 \%$ of feeding activity occurring in this region opposed to $64 \%$ in $M$. pygmaeus. These observations are in line with earlier studies which showed that both predatory species occupy different strata of the tomato plant when cohabitating the same plant, with $N$. tenuis spending significantly more time on the uppermost region of the plant and M. pygmaeus on the lower leaves of apical region (Perdikis et al., 2014).

Despite the large amount of time spent by both species of mirids feeding on the sweet pepper plants, as of yet, neither of the two species have been described producing crop damage which could affect yield (Urbaneja et al., 2005). Indeed, M. pygmaeus is considered a safe and efficient candidate to be used for sweet pepper IPM strategies in Northern Europe to supplement aphid control (Messelink et al., 2015; Pérez-Hedo and Urbaneja, 2015). The use and conservation of $N$. tenuis as a biocontrol agent in sweet pepper 
is uncommon in Europe, particularly in the Mediterranean basin where this mirid is naturally abundant. However, in other pepper producing regions such as greenhouses in Kochi Prefecture, Japan, N. tenuis is considered a key natural enemy against whiteflies, aphids and thrips, where despite reaching high populations it has not been described to cause damage through plant feeding (Komi, 2016).

Despite significant differences in plant feeding behaviour between the two mirid species, the level of cell wounding was sufficient in both species to activate the defence mechanisms in sweet pepper, as has been described in tomato plants (Pérez-Hedo et al., 2015a, 2015b; Pappas et al., 2015, 2016; Naselli et al., 2016). A significant increase in ABA and JA signalling pathways was found in both $N$. tenuis and M. pygmaeus-punctured plants which are co-regulated in response to wounding. This was in accordance with the results of the relative expression of the target defensive genes, ASR1 and PIN2, respectively. Nevertheless, the levels of the phytohormone SA, which has been described as an herbivore repellent in previous studies, (Erb et al., 2012; Shi et al., 2016; Liu et al., 2016) were not significantly different between mirid-punctured plants and intact plants, although there was a tendency for it to be higher in punctured plants. Furthermore, the related gene $P R-1$ was upregulated for $N$. tenuis-punctured plants but not for M. pygmaeuspunctured plants. $P R-1$ has been recognised as a SA marker gene, but it is also responsive to external stimuli and internal signals such as azelaic acid or pipecolic acid which were not determined in the present study (Jung et al., 2009; Návarová et al., 2012). It is therefore likely that mirid inoculation enhances the levels of other internal stimuli. In addition, MeSA, a compound which plays an antagonistic role with free SA levels and a synergistic role 
with JA signalling (Boachon et al., 2014), is significantly increased following inoculation by either mirid species.

The results confirmed that the release of VOCs by punctured-sweet pepper induces the observed repellency and attractiveness to the tested phytophage and natural enemy species. Indeed, plants exposed to N. tenuis and M. pygmaeus feeding were associated with repellence of both arthropod pests, F. occidentalis and B. tabaci, and attraction of the parasitoid E. formosa. Similarly, the feeding activity of $N$. tenuis in tomato plants have been found to be responsible for the repellence of B. tabaci and Tuta absoluta Meyrick (Lepidoptera: Gelechiidae), and for the attraction of E. formosa (Pérez-Hedo et al., 2015a, 2015b). However, unlike the induced plant response to N. tenuis feeding activities, those induced by M. pygmaeus and Dicyphus maroccanus Wagner (Hemiptera: Miridae) were found not to repel B. tabaci and became attractive to T. absoluta (Pérez-Hedo et al., 2015b). These results in tomato were found to be related to the upregulation of ABA and JA signalling pathways (Pérez-Hedo et al., 2015a), and suggest that M. pygmaeus causes a distinct response in tomato and pepper and are consequently capable of emitting different blends of volatiles.

The HIPVs identified in this work were classified in three important groups, green leaf volatiles (GLVs) involving the fatty acid/lipoxygenase biosynthesis pathway, terpenes (the isoprenoid pathway) and methyl salicylate, MeSA, (the shikimic acid pathway). A future step would be to identify the role of each HIPV within the blend and their capacity to repel and/or attract different sweet pepper pests. Of the identified volatile compounds, octyl acetate was only recorded in M. pygmaeus-punctured plants. Octyl acetate has been described as a specific compound acting as sexual pheromone emitted by females on some species of the Miridae family 
such as Phytocoris spp (Millar et al., 1997; Millar and Rice, 1998; Zhang and Aldrich, 2008). It could be that this compound was emitted by M. pygmaeus and traces were left on the plant. In any case, the role of this volatile on M. pygmaeus deserves further investigation.

Under cage conditions, choice experiments showed that B. tabaci and F. occidentalis were both less likely to reside on mirid-punctured plants than on intact plants. This lower preference might be a consequence of indirect defence induction mediated by mirids. VOCs inside the box might be mixedup, hence the consequence of unequal distribution of both pests may be attributed to the contact and feeding upon the plants with high content on JA, which can be a feeding deterrent for arthropod pests (Santamaria et al., 2013; Zhurov et al., 2014). Macrolophus pygmaeus-punctured tomato plants were observed to increase locally and systematically the accumulation of transcripts and activity of protease inhibitors that are known to be involved in plant responses, resulting in the decreased life history traits of the twospotted spider mite Tetranychus urticae Koch (Acari: Tetranychidae) (Pappas et al., 2015). In the case of sweet pepper, further research should be done to elucidate these direct defence effects on subsequent herbivore development and reproduction.

Tomato plants exposed to M. pygmaeus with all individuals subsequently removed, as in this study, were previously described to remain vaccinated for up to two weeks (Pappas et al., 2015). The impact of N. tenius in sweet pepper is demonstrated to remain active for 7 to 14 days. The latter finding would be useful for growers applying a nursery release of $N$. tenuis as a vaccine, adopting such a practice on sweet pepper crops might increase resilience to pest attacks. This would be an added benefit of $N$. tenuis and M. pygmaeus in order to effectively manage the key sweet pepper pests, 
B. tabaci and F. occidentalis. After vaccination, mirids could become established in the crop so they could further contribute to the management of sweet pepper pests. However, the efficacy of $N$. tenuis and M. pygmaeus preying upon a mixed diet of sweet pepper pests and their compatibility with other natural enemies already adapted to sweet pepper, such as A. swirskii or O. laevigatus warrant further investigation. Another application derived from this study would be the ability to manipulate the attractant and repellent capacity of sweet pepper by exposure to HIPVs. As an example, the use of volatile dispensers to emit regular concentrations of one or a blend of these volatiles could result in saturated repellent and attractant environments for pests and natural enemies, respectively. Exploring the capacity to activate plant defences in intact sweet pepper by exposing the plants to these volatiles or volatile blends, would open the door to new ways of pest control in sweet pepper as successfully demonstrated in tomato plants (Pérez Hedo et al., 2015a). 


\section{Supporting Information}

\section{Table S.1.}

Statistics ( $P, F$ and degree freedom values) for the two-way ANOVA comparison of time spent by males and females of $N$. tenuis and $M$. pygmaeus in eight different behavioural states on sweet pepper plant, and the resident time of each predator and sex on the three designed locations.

\begin{tabular}{llll}
\hline Behaviours & Species & Sex & Species * Sex \\
\hline Grooming & $F_{1,76}=2.28, P=0.13$ & $F_{1,76}=2.30, P=0.13$ & $F_{1,76}=0.03, P=0.86$ \\
\hline Feeding & $F_{1,76}=22.37, P<0.0001$ & $F_{1,76}=0.10, P=0.76$ & $F_{1,76}=4.58, P=0.03$ \\
\hline Flying & $F_{1,76}=0.11, P=0.74$ & $F_{1,76}=2.30, P=0.13$ & $F_{1,76}=0.07, P=0.78$ \\
\hline Ovipositing & $t_{1,38}=1.56, P=0.13$ & $/$ & $/$ \\
\hline Resting & $F_{1,76}=2.85, P=0.09$ & $F_{1,76}=1.15, P=0.29$ & $F_{1,76}=0.20, P=0.66$ \\
\hline Antennating & $F_{1,76}=3.82, P=0.05$ & $F_{1,76}=1.90, P=0.17$ & $F_{1,76}=0.15, P=0.70$ \\
\hline Walking & $F_{1,76}=8.46, P=0.0048$ & $F_{1,76}=9.14, P=0.003$ & $F_{1,76}=1.67, P=0.20$ \\
\hline Walk.- Antenn. & $F_{1,76}=1.55, P=0.22$ & $F_{1,76}=4.03, P=0.05$ & $F_{1,76}=0.31, P=0.58$ \\
\hline Locations & & & \\
\hline Apical region & $F_{1,76}=6.81, P=0.01$ & $F_{1,76}=3.47, P=0.06$ & $F_{1,76}=0.52, P=0.47$ \\
\hline Basal region & $F_{1,76}=4.75, P=0.03$ & $F_{1,76}=0.81, P=0.37$ & $F_{1,76}=0.37, P=0.54$ \\
\hline Outside & $F_{1,76}=2.61, P=0.11$ & $F_{1,76}=4.75, P=0.03$ & $F_{1,76}=6.28, P=0.014$ \\
\hline
\end{tabular}





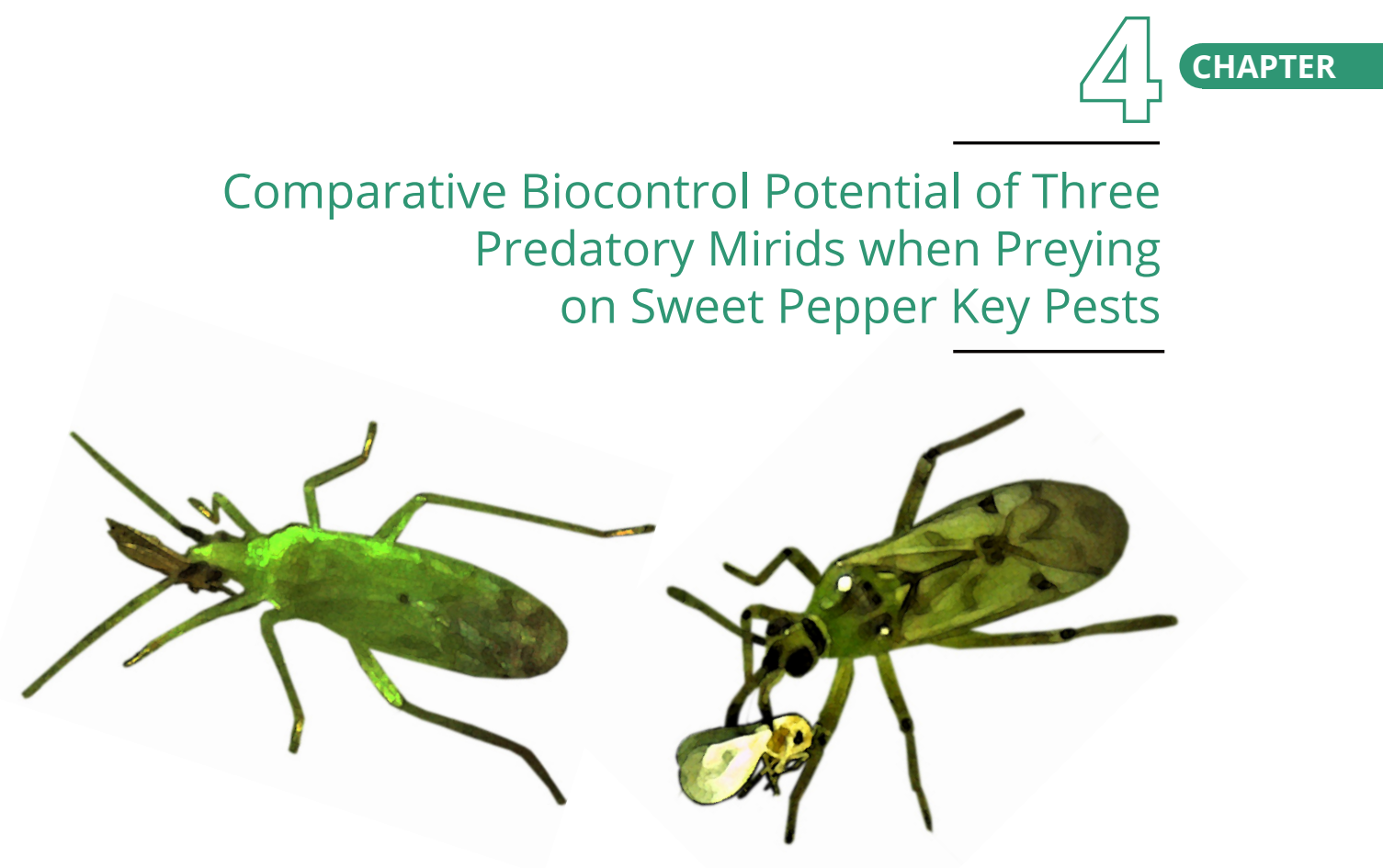





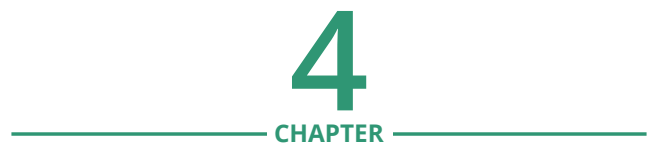

\title{
Comparative biocontrol potential of three predatory mirids when preying on sweet pepper key pests
}

\author{
Sarra Bouagga, Alberto Urbaneja, Meritxell Pérez-Hedo \\ Biological Control (2018), DOI: 10.1016/j.biocontrol.2018.03.003
}

\section{Abstract}

Pest management in protected sweet pepper crops mainly rely on biological control strategies. Recently, the zoophytophagous predatory mirids, Nesidiocoris tenuis, Macrolophus pygmaeus, and Dicyphus maroccanus, proved to be effective in the control of aphids on sweet pepper, for which the current biological control strategies have been meagre. The next step to integrate the possible use of these mirids in sweet pepper biological control practices would be to ascertain their potential control on other sweet pepper pests. In this research, a comparative study to assess the establishment and the efficacy of $N$. tenuis, M. pygmaeus, and D. maroccanus on the two sweet pepper key pests; the thrips, Frankliniella occidentalis, and the whitefly, Bemisia tabaci, was conducted. This study was carried out with two different temperatures regimes, $20{ }^{\circ} \mathrm{C}$ and $27{ }^{\circ} \mathrm{C}$, which simulated the mean temperature registered in the two main crop cycles in Spain (the winter and summer planting period). Both, N. tenuis and M. pygmaeus; were able to establish on sweet pepper and significantly reduced the number of $F$. occidentalis and B. tabaci adults, larvae and nymphs. Macrolophus pygameus had the highest density at $20^{\circ} \mathrm{C}$, whereas $N$. tenuis was more abundant at $27{ }^{\circ} \mathrm{C}$. In contrast, $D$. maroccanus was less abundant under both temperatures studied; and did not reduce neither F. occidentalis nor B. tabaci infestations in this crop. None of the three mirids were observed to cause any damage to the pepper plant. The implications of these results applied to the use of mirids in sweet pepper crops are discussed.

Key words: Nesidiocoris tenuis, Macrolophus pygmaeus, Dicyphus maroccanus, biological control, temperature regime. 


\subsection{Introduction}

Protected sweet pepper (Capsicum spp.) is one of the most strategic horticulture crops, widely cultivated in the South-eastern Spain. During the last twenty years, the ever demanding standards for healthy, residue-free products have pushed the growers to explore and adopt environmentally friendly strategies to manage sweet pepper pests (Calvo et al., 2009a; van Lenteren, 2012). The western flower thrips, Frankliniella occidentalis Pergande (Thysanoptera: Tripidae), is one of the most serious pests of sweet pepper, both in the greenhouse and in the open field (Tommasini and Maini, 1995; Van Driesche et al., 1998). In addition to the direct damages, such as fruit abortion or fruit scarring, caused by F. occidentalis, it may cause important indirect damages through its role as a vector of the tomato spotted wilt virus (TSWV) (Lacasa et al., 1991; Peters, 1996). Additionally, the sweet potato whitefly, Bemisia tabaci Gennadius (Hemiptera: Aleyrodidae), is considered to be a secondary pest; which causes direct injury as a result of sap removal, honeydew build-up with sooty mould, physiological disorders, and the transmission of plant viruses (De Barro et al., 2011; Fortes et al., 2012). Therefore, the biological control of both pests in sweet pepper has become a priority in South-eastern Spain. Since the end of the last century, many natural enemies of thrips and whiteflies have been reported and evaluated for their efficacy (Sánchez et al., 2000, Sánchez and Lacasa, 2002; Urbaneja et al., 2001, 2002; Stansly et al., 2005; Blom et al., 2003). All these studies have led to the current pest management strategy in sweet pepper, which is based on the release of the generalist biocontrol agents, the predatory mite Amblyseius swirskii Athias-Henriot (Acari: Phytoseiidae) and the minute pirate bug Orius laevigatus Fieber (Hemiptera: Anthocoridae) (Calvo et al., 
2009a). The augmentative release of both predators successfully manages two of the key pests of this crop, B. tabaci and F. occidentalis (Blom, 2008, Calvo et al., 2009a).

Despite the success of the current biological control-based management program in sweet pepper, better control of aphids in this crop is still needed (Bloemhard and Ramakers, 2008; Belliure et al., 2008, Sánchez et al., 2011). Traditionally, aphids have been managed through the release of a combination of specialized predators, mainly the predatory midge Aphidoletes aphydimiza Rondani (Diptera: Cecidomyiidae) and parasitoids, mainly Aphidius Colemani Viereck (Hymenoptera: Braconidae) (Blom, 2008). However, the need for multiple releases of natural enemies increases the final cost of the biocontrol program (Messelink et al., 2011a). In addition, these releases can be disrupted by the abundance of hyperparasitoids (Sánchez et al., 2011), and by predator interference, where A. swirskii and O. laevigatus display intraguild predatory behaviour on the eggs of the midge (Messelink et al., 2011b; Hosseini et al., 2010). Therefore, there is a continuous need of investigations to identify and evaluate alternative natural enemies that can be used for the management of aphids in this crop.

Generalist predators are widely known to contribute to the management of a wide range of agricultural pest, including aphids, around the world (Perdikis and Lykouressis, 2004, Messelink et al., 2011a, 2015; Pérez-Hedo and Urbaneja, 2015; Sylla et al., 2016). Previous studies have demonstrated that under laboratory conditions the zoophytophagous mirid predators, Nesidiocoris tenuis Reuter and Macrolophus pygmaeus Rambur (Hemiptera: Miridae), successfully feed upon the most commonly occurring sweet pepper aphid, Myzus persicae Sulzer (Hemiptera: Aphididae), also known as the green peach aphid (Perdikis and Lykouressis 2002, 2004; 
Valderrama et al., 2007; Fantinou et al., 2009). More recently, under semifield conditions, Pérez-Hedo and Urbaneja (2015) observed how N. tenuis, M. pygmaeus, and Dicyphus maroccanus Wagner (Hemiptera: Miridae) significantly reduced the number of $M$. persicae in sweet pepper plants, reaching a level of aphid reduction close to $100 \%$. Furthermore, Messelink et al. (2015) and De Backer et al. (2015) showed the release of M. pygmaeus and D. tamaninii Wagner (Hemiptera: Miridae) prior to infestation in combination with the application of supplemented food enhanced the management of $M$. persicae on sweet pepper. These results suggest the use of mirids in sweet peppers may just be the alternative needed in aphid management. However, the capacity of mirids to reduce thrips and whiteflies in sweet pepper crops has not been completely characterized.

To this end, we evaluated the efficacy of $N$. tenuis, M. pygmaeus and D. maroccanus as predators of thrips and whiteflies and also assessed the establishment of the mirids, on sweet pepper plants under two different temperature regimes $\left(20{ }^{\circ} \mathrm{C}\right.$ and $\left.27{ }^{\circ} \mathrm{C}\right)$. Both selected temperatures simulated the registered means in the two main sweet pepper planting cycles in the Southeast of Spain.

\subsection{Material and methods}

\subsubsection{Insects and Plants}

Nesidiocoris tenuis, M. pygmaeus, and the whitefly, B. tabaci were obtained from a commercial supplier (NESIBUG® and MYRICAL®; Koppert Biological Systems, S.L., Águilas, Murcia, Spain). Each mirid species was provided in plastic bottles containing 500 individuals (mature 
nymphs and young adults), approximately 3-day-old specimens (FJ Calvo, Koppert BS; Personal Communication). Each predator species was released separately on sweet pepper plants "var. Lipari” (Dulce italiano, Mascarell semillas S.L, Valencia, Spain) until used, inside $60 \times 60 \times 60$-cm plastic cages (BugDorm-2 insect tents, MegaView Science Co., Ltd., Taichung, Taiwan) and supplied with Ephestia kuehniella Zeller (Lepidoptera: Pyralidae) eggs (Entofood ${ }^{\circledR}$; Koppert B.S.) as additional food. Bemisia tabaci adults were kept on sweet pepper plants (the same cultivar, as described above) inside plastic tents in $30 \times 30 \times 30-\mathrm{cm}$ plastic cages (BugDorm-1 insect tents, MegaView Science Co., Ltd., Taichung, Taiwan), until their use. The individuals of the third mirid species, D. maroccanus, were obtained from a laboratory colony on pesticide free tomato seedlings "var. Optima" which had already been established in the Instituto Valenciano de Investigaciones Agrarias (IVIA), as described in Pérez-Hedo and Urbaneja (2015).

The F. occidentalis adults, were also obtained from a colony previously established at IVIA in 2010 originally collected from Campo de Cartagena (Murcia, Spain). The thrips colony was raised on bean plants (Phaseolus vulgaris L., Fabales: Fabaceae). All stock colonies described above were housed in climatic chambers at $25 \pm 2{ }^{\circ} \mathrm{C}, 65 \pm 10 \% \mathrm{RH}$ under a 14:10 h (L:D) photoperiod at IVIA.

The pesticide-free sweet pepper seedlings (Capsicum annuum L. var. "Lipari") were transplanted into plastic pots $(8 \times 8 \times 8 \mathrm{~cm})$ containing a mixture of natural soil with local peat moss and were housed in a climatic chamber under the same environmental conditions as described above. Plants (approximately $25 \mathrm{~cm}$ in height) with 12 fully developed leaves were used for the experiments described below. 


\subsubsection{Experimental design and sampling}

The experiment was conducted in plastic screened cages $(60 \times 60$ $\times 60-\mathrm{cm}$ BugDorm-2, as described above), which were maintained in two identical cabinets of a glasshouse located at IVIA, under two different temperature regimes, $20 \pm 2{ }^{\circ} \mathrm{C}$ and $27 \pm 2{ }^{\circ} \mathrm{C}$. The relative humidity was $65 \pm 10 \%$ and the natural photoperiod was used. Temperature and relative humidity were maintained during the entire duration of the experiment by the climate controller Ambitrol 500 (Sistemes Electrònics Progrès SA, Bellpuig. Spain). The experiment was carried out during the eleven weeks; between mid-March to the beginning of June, 2015.

To evaluate the efficiency of N. tenuis, M. pygmaeus, and D. maroccanus to control a mixed infestation of F. occidentalis and B. tabaci on sweet pepper a randomized complete block design with four treatments (release of N. tenuis, release of M. pygmaeus, release of D. maroccanus and a control without predator release) replicated four times each (cage=replicate) were used in both of the two glasshouse cabinets. Mirids were released stimulating the strategy of predator in first (pre-plant release) (Calvo et al., $2012 b)$. This strategy entails mirids being released in the nursery 5-7 days before transplanting the sweet pepper plants upon which mirid individuals had already laid eggs; therefore, small nymphs and adults were still present. In each replicate, eight healthy sweet pepper plants $(25 \mathrm{~cm}$ high) and four couples (male/female) of each species of mirid were introduced on the same day (1 adult/plant). Each mirid species was separately released in quadruplets. The control treatment did not receive mirid releases. During the first two weeks of the experiment, approximately $0.1 \mathrm{~g} /$ plant of frozen eggs of E. kuehniella were equally distributed on the plants by 
manually sprinkling. The addition of this alterntative food facilitated mirid establishment and oviposition (Urbaneja-Bernat et al., 2015). The plants were irrigated twice a week throughout the experiment.

Two weeks after the release of mirids, 8 couples (male/female) (5 adults $/ \mathrm{m}^{2}$ ) of $F$. occidentalis and 16 couples $\left(10\right.$ adults $/ \mathrm{m}^{2}$ ) of $B$. tabaci were introduced per cage eight times (1 infestation per week). Both pests were separately introduced into Petri dishes that were then left open at the base of the plant in each of the cages. These selected rates were chosen to simulate a strong and early whitefly and thrips infestation.

One week after the first pest infestation, the samplings were started in both of the glasshouse cabinets at $20 \pm 2{ }^{\circ} \mathrm{C}$ and $27 \pm 2{ }^{\circ} \mathrm{C}$. From four randomly selected plants per replicate; three leaves (one from the upper, one from middle, and one from the lower part of the plant) were inspected and the number of live F. occidentalis and B. tabaci adults, larvae, and nymphs were recorded. The same whole plants were also inspected to count the total number of mirid adults and nymphs. Eight evaluations (one per week) were conducted. Special care was always taken to sample the control cages first and then the cages containing the predators, to reduce the risk of accidental contamination among the treatments.

\subsubsection{Statistical analysis}

The total number of F. occidentalis and B. tabaci per sampled leaf and the total number of mirids per plant were $\log (x+1)$ transformed prior to analysis using Generalized Linear Mixed Models (GLMM). Treatment was considered to be a fixed factor while time in weeks, a random one. Each GLMM used a normal distribution and identity link function. 
Untransformed values are presented in the figures. Whenever a significant difference was found, pairwise comparisons of the fixed factor levels were performed with the least significant difference (LSD) post-hoc test $(P<0.05)$. To calculate the percentage of F. occidentalis and B. tabaci reduction; Abbott's formula was applied (Abbott, 1925) using the number of F. occidentalis and B. tabaci accumulated at the end of the experiment (week 8; the area under the duration of the experiment incidence curve) (Calvo et al., 2009b). To know whether differences between the percentages of reduction existed, data were log transformed then a one-way analysis of variance (ANOVA) followed by comparison of means (Tukey's test) at $\alpha<0.05$ or one-tailed Student's $t$ test $(P<0.05)$ was performed. The results were expressed as the means \pm standard error.

\subsection{Results}

\subsubsection{Frankliniella occidentalis management}

In the glasshouse at $20^{\circ} \mathrm{C}$, the three species of mirids significantly reduced the populations of $F$. occidentalis, when compared to the control (Fig.4.1.a) (Table4.1). However, the number of F.occidentalis was significantly lower in the cages where $N$. tenuis and M. pygmaeus were released when compared to the cages in which D. maroccanus was released. 
Table 4.1.

$P$ values for the pairwise comparison of the number of $F$. occidentalis (adults + larvae) per leaf which received a release of $D$. maroccanus $(D m), M$. pygmaeus $(M p), N$. tenuis $(N t)$ and control without release (C). Values in bold correspond to significant differences between the treatments.

\begin{tabular}{lcccc}
\hline Treatments & \multicolumn{3}{c}{$20^{\circ} \mathrm{C}$} & \multicolumn{2}{c}{$2{ }^{\circ} \mathrm{C}$} \\
\cline { 2 - 5 } & $t_{124}$ & $P$ & $t_{124}$ & $P$ \\
\hline C vs. $D m$ & $\mathbf{2 . 8 8 1}$ & $\mathbf{0 . 0 0 5}$ & 3.914 & $<\mathbf{0 . 0 0 1}$ \\
\hline $\mathrm{C}$ vs. $M p$ & $\mathbf{6 . 5 7 2}$ & $<\mathbf{0 . 0 0 1}$ & $\mathbf{6 . 6 7 7}$ & $<\mathbf{0 . 0 0 1}$ \\
\hline $\mathrm{C}$ vs. $N t$ & $\mathbf{5 . 9 5 0}$ & $<\mathbf{0 . 0 0 1}$ & $\mathbf{6 . 6 0 1}$ & $<\mathbf{0 . 0 0 1}$ \\
\hline$D m$ vs. $M p$ & $\mathbf{3 . 6 9 1}$ & $<\mathbf{0 . 0 0 1}$ & $\mathbf{2 . 7 6 3}$ & $\mathbf{0 . 0 0 7}$ \\
\hline$D m$ vs. $N t$ & $\mathbf{3 . 0 7 0}$ & $\mathbf{0 . 0 0 3}$ & $\mathbf{2 . 6 8 7}$ & $\mathbf{0 . 0 0 8}$ \\
\hline$M p$ vs. $N t$ & 0.621 & 0.536 & 0.076 & 0.940 \\
\hline
\end{tabular}

No significant difference in the percentage of $F$. occidentalis reduction was found between the sweet pepper plants that received releases of $N$. tenuis or M.pygmaeus. At week 8, N. tenuis and M. pygmaeus reduced the infestation of $F$. occidentalis by $82 \%$ and $87 \%$, respectively. In contrast, D. maroccanus only achieved a 33\% reduction, which was significantly lower when compared to the reduction achieved by $M$. pygmaeus and $N$. tenuis $\left(F_{2-11}=12.42 ; P=0.003\right)$ (Fig.4.1.b). Similar results were recorded from cages maintained in the glasshouse at $27^{\circ} \mathrm{C}$ (Table 4.1). Nesidiocoris tenuis and M. pygmaeus were more voracious and reduced the infestation of F. occidentalis by $89 \%$ and $90 \%$, respectively, at week $8\left(F_{2-11}=16.95 ; P=0.001\right)$. Dicyphus maroccanus was less efficient and reduced $45 \%$ of the F. occidentalis population when compared to control treatment (Fig.4.1.d). At this temperature, no differences were observed between the percentages reduction of F. occidentalis in sweet pepper, which received releases of $N$. tenuis, and those which received M. pygmaeus (Table 4.1). 
$20^{\circ} \mathrm{C}$

(a)

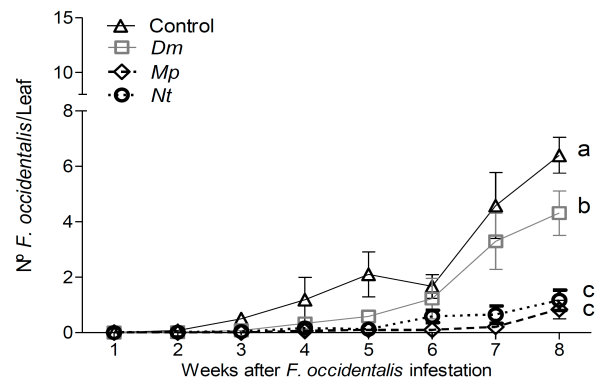

$27^{\circ} \mathrm{C}$ (c)

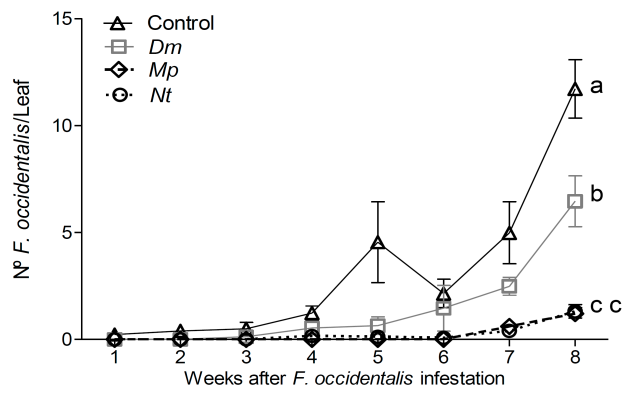

(b)

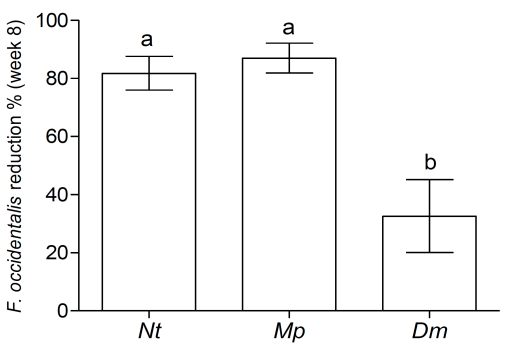

(d)

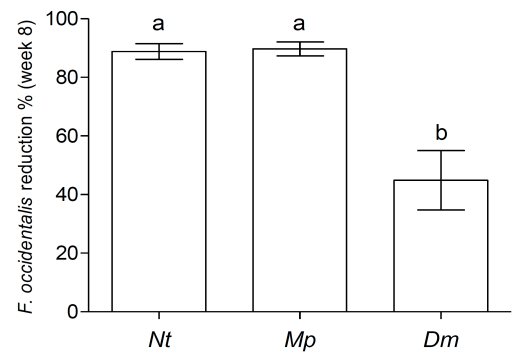

Figure 4.1.

(a) Number (mean $\pm \mathrm{SE}$ ) of $F$. occidentalis (adults + larvae) per sweet pepper leaf at 20 ${ }^{\circ} \mathrm{C}$, (b) percentage reduction (Abbott) (mean $\pm \mathrm{SE}$ ) of $F$. occidentalis individuals at $20{ }^{\circ} \mathrm{C}$, (c) number (mean $\pm \mathrm{SE}$ ) of $F$. occidentalis (adults + larvae) per sweet pepper leaf at $27^{\circ} \mathrm{C}$, and (d) percentage reduction (Abbott) (mean $\pm \mathrm{SE}$ ) of $\mathrm{F}$. occidentalis individuals at $27^{\circ} \mathrm{C}$ in a glasshouse experiment comparing the effectiveness of the mirid predators, $N$. tenuis, $M$. pygmaeus, and $D$. maroccanus at different time intervals under the two temperature regimes mentioned above. Bars with different letters are significantly different (ANOVA, Tukey's multiple comparison test $a<0.05$ ). 


\subsubsection{Bemisia tabaci management}

The number of $B$. tabaci per sampled leaf in the cages maintained in the glasshouse at $20^{\circ} \mathrm{C}$ was low for all the treatments. The release of M. pygmaeus and $N$. tenuis significantly reduced the $B$. tabaci infestation when compared to the D. maroccanus and control cages. No significant differences were found between the numbers of $B$. tabaci counted in D. maroccanus and control cages (Fig.4.2.a) (Table 4.2).

\section{Table 4.2.}

$P$ values for the pairwise comparison of the number of $B$. tabaci (adults + nymphs) per leaf which received a release of $D$. maroccanus (Dm), M. pygmaeus (Mp), N. tenuis (Nt) and control without release (C). Values in bold correspond to significant differences between the treatments.

\begin{tabular}{lcccc}
\hline Treatments & \multicolumn{2}{c}{$20^{\circ} \mathrm{C}$} & \multicolumn{2}{c}{$27^{\circ} \mathrm{C}$} \\
\cline { 2 - 5 } & $t_{124}$ & $P$ & $t_{124}$ & $P$ \\
\hline $\mathrm{C}$ vs. $\mathrm{Dm}$ & 1.736 & 0.085 & $\mathbf{2 . 5 0 9}$ & $\mathbf{0 . 0 1 3}$ \\
\hline $\mathrm{C}$ vs. $\mathrm{Mp}$ & $\mathbf{5 . 4 1 3}$ & $<\mathbf{0 . 0 0 1}$ & $\mathbf{5 . 2 5 7}$ & $<\mathbf{0 . 0 0 1}$ \\
\hline $\mathrm{C}$ vs. $N t$ & $\mathbf{4 . 4 5 6}$ & $<\mathbf{0 . 0 0 1}$ & $\mathbf{5 . 2 6 2}$ & $<\mathbf{0 . 0 0 1}$ \\
\hline$D m$ vs. $M p$ & $\mathbf{3 . 6 7 7}$ & $<\mathbf{0 . 0 0 1}$ & $\mathbf{2 . 7 4 8}$ & $\mathbf{0 . 0 0 7}$ \\
\hline$D m$ vs. $N t$ & $\mathbf{2 . 7 2 0}$ & $\mathbf{0 . 0 0 7}$ & $\mathbf{2 . 7 5 3}$ & $\mathbf{0 . 0 0 7}$ \\
\hline$M p$ vs. $N t$ & 0.957 & 0.340 & 0.005 & 0.996 \\
\hline
\end{tabular}

The infestation by B. tabaci at week 8 was reduced by $82 \%$ and $65 \%$ by $M$. pygmaeus and $N$. tenuis, respectively $\left(t_{6}=2.263 ; P=0.108\right)$ (Fig.4.2.b). A similar trend was observed when the experiment was conducted at $27^{\circ} \mathrm{C}$; however, under this temperature the three mirid species significantly reduced the $B$. tabaci infestation when compared to the control. The number of B. tabaci was significantly lower in the $N$. tenuis and M. pygmaeus cages 
when compared to that in the D. maroccanus cages (Fig.4.2.c) (Table 4.2). A reduction of $96 \%$ of the infestation was obtained by M. pygmaeus and $N$. tenuis, whereas, D. maroccanus was less efficient and only reduced the B. tabaci populations by $46 \%\left(F_{2-11}=7.06 ; P=0.015\right)$ (Fig.4.2.d).

$20^{\circ} \mathrm{C}$

(a)

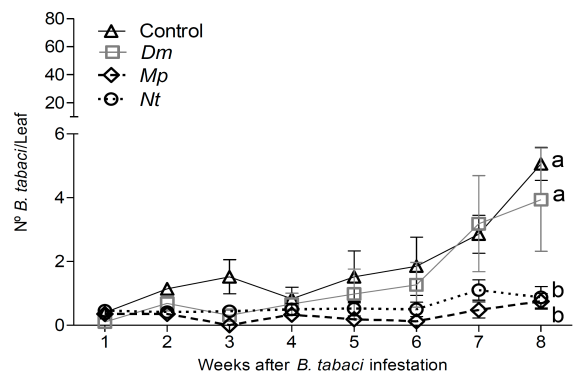

$27^{\circ} \mathrm{C}$

(c)

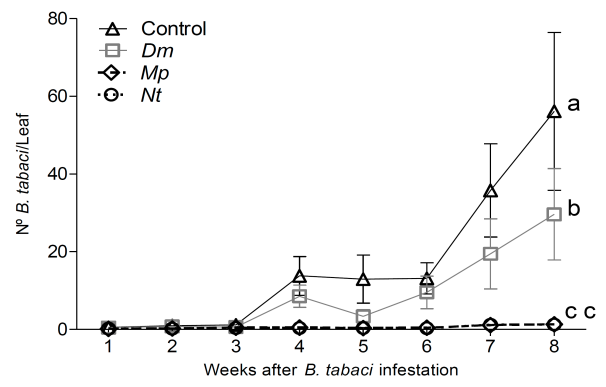

(b)

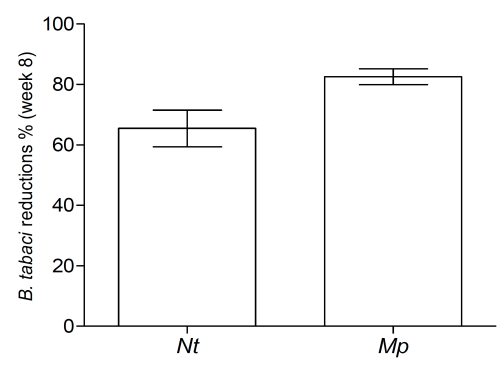

(d)

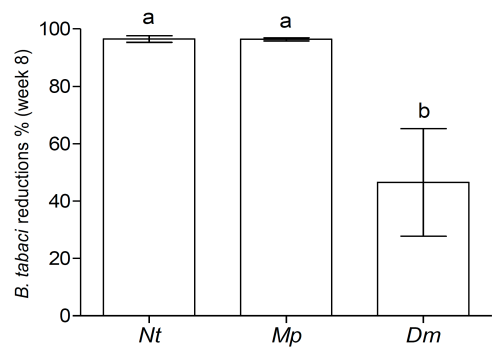

Figure 4.2.

(a) Number (mean $\pm \mathrm{SE}$ ) of $B$. tabaci (adults + nymphs) per sweet pepper leaf at $20{ }^{\circ} \mathrm{C}$, (b) percentage reduction (Abbott) (mean $\pm \mathrm{SE}$ ) of $B$. tabaci individuals at $20{ }^{\circ} \mathrm{C}$ (c) Number (mean $\pm \mathrm{SE}$ ) of $B$. tabaci (adults + nymphs) per sweet pepper leaf at $27^{\circ} \mathrm{C}$, and (d) percentage reduction (Abbott) (mean $\pm \mathrm{SE}$ ) of $B$. tabaci individuals at $27^{\circ} \mathrm{C}$ in a glasshouse experiment comparing the effectiveness of the mirid predators, $N$. tenuis, M. pygmaeus, and D. maroccanus at different time intervals under the two temperature regimes mentioned above. Bars with different letters are significantly different (ANOVA, Tukey's multiple comparison test $a<0.05$ ). 


\subsubsection{Mirid populations}

At $20{ }^{\circ} \mathrm{C}$, M. pygmaeus, with an average of $1.6 \pm 0.2$ individuals/plant, was significantly more abundant than $N$. tenuis $(1.15 \pm 0.3)$, which in turn was higher than D. maroccanus $(0.3 \pm 0.2)$ (Fig.4.3.a) (Table 4.3). In contrast, when the experiment was conducted at $27^{\circ} \mathrm{C}, \mathrm{N}$. tenuis was the most abundant predator with an average of $2.1 \pm 0.4$ individuals/plant, which was significantly higher than both the M. pygmaeus and D. maroccanus populations (Table 4.3). Significant differences were obtained between the M. pygmaeus $(1.2 \pm 0.2)$ and D. maroccanus $(0.25 \pm 0.05)$ population numbers, with the latter being very low throughout the entire experiment (Fig.4.3.b) (Table 4.3).

\section{Table 4.3.}

$P$ values for the pairwise comparison of the number of mirids (adults + nymphs) per plant that received $D$. maroccanus $(D m), M$. pygmaeus $(M p)$, and $N$. tenuis $(N t)$ releases. Values in bold correspond to significant differences between the treatments.

\begin{tabular}{lcccc}
\hline Treatments & \multicolumn{2}{c}{$20^{\circ} \mathrm{C}$} & \multicolumn{2}{c}{$27^{\circ} \mathrm{C}$} \\
\cline { 2 - 5 } & $t_{124}$ & $P$ & $t_{124}$ & $P$ \\
\hline$D m$ vs. $M p$ & 7.292 & $<0.001$ & 3.992 & $<0.001$ \\
\hline$D m$ vs. $N t$ & 4.886 & $<0.001$ & 7.754 & $<0.001$ \\
\hline$M p$ vs. $N t$ & $\mathbf{2 . 4 0 6}$ & $\mathbf{0 . 0 1 8}$ & 3.762 & $<0.001$ \\
\hline
\end{tabular}


$20^{\circ} \mathrm{C} \quad$ (a)

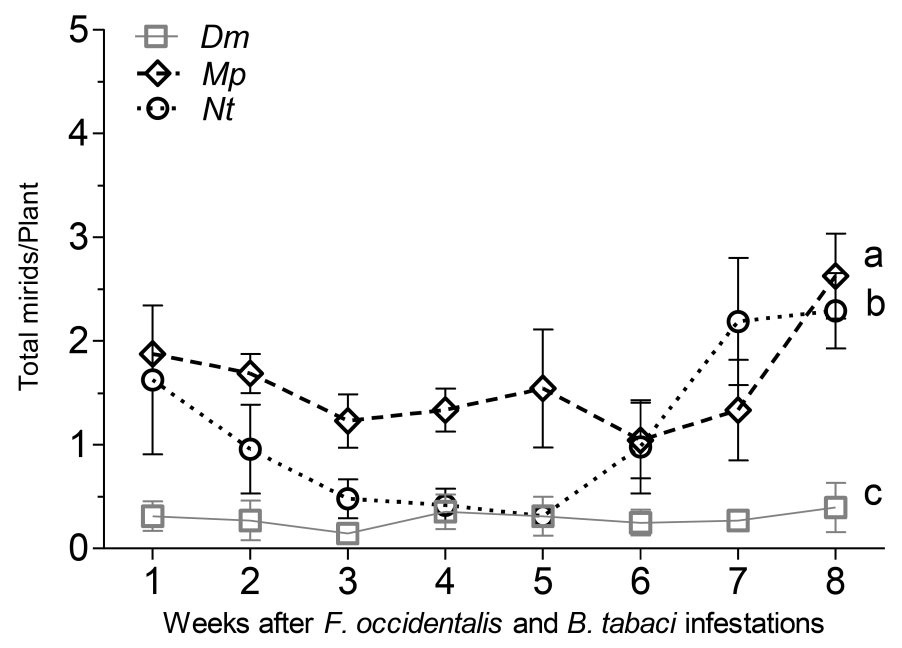

$27^{\circ} \mathrm{C}$

(b)

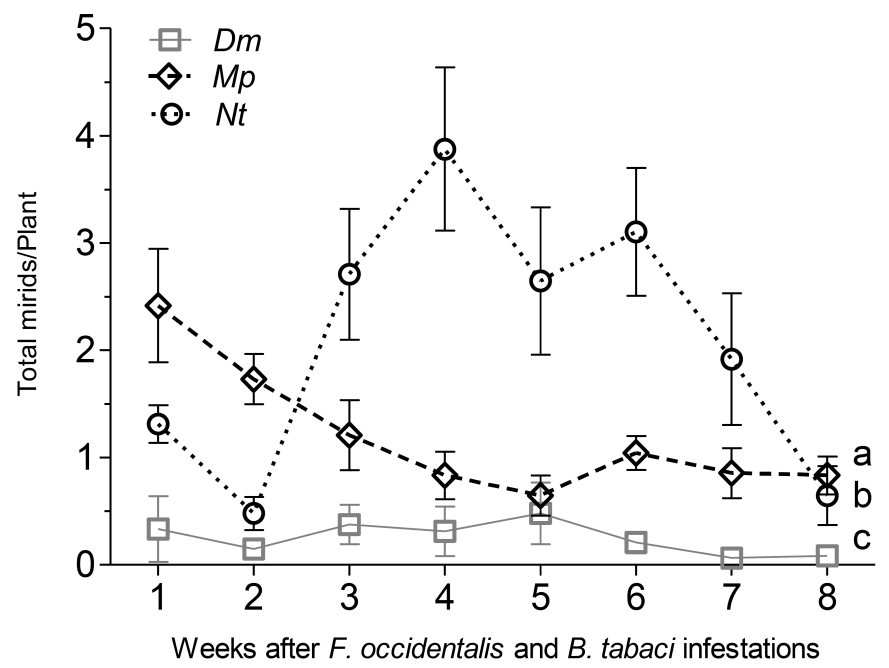

Figure 4.3.

Number (mean $\pm \mathrm{SE}$ ) of $N$. tenuis, M. pygmaeus, and D. maroccanus (adults + nymphs) per sweet pepper plants at different time intervals under two temperature regimes (a) $20^{\circ} \mathrm{C}$ and (b) $27^{\circ} \mathrm{C}$. 


\subsection{Discussion}

Our results show that the pre-plant release strategy of the three selected predatory mirids, supported by the addition of E. kuehniella eggs, successfully established on sweet pepper plants although the number of mirids per plant was much lower in the case of D. maroccanus. Accordingly, the number of individuals established by the release and augmentation of $N$. tenuis or M. pygmaeus before the infestation of thrips and whiteflies resulted in continuous suppression of both pests. The low abundance of D. maroccanus was relative to the level of control reached by both pests, which remained around $40 \%$ in both temperature regimes.

Although, the members of Miridae are common predators in Mediterranean agroecosystems and spontaneously colonize various agricultural crops, including sweet pepper (Perdikis and Lykouressis, 1996; Tavella et al., 1997; Castañé et al., 2004; Gabarra et al., 2004), their commercial use in this crop is underrepresented. The mirid predators are known to be generally associated to hairy plants (Wheeler, 2001), but our results and previous studies have shown their establishment and reproduction to also be possible in plants lacking hair and or trichomes (Perdikis and Lykouressis, 2004; Urbaneja et al., 2005; Barbara et al., 2011; Messelink et al., 2015; PérezHedo and Urbaneja, 2015).

Our results illustrated differences in the abundance of each predator species in the two temperatures tested. Macrolophus pygmaeus showed strong preference for the lower temperature tested where it was significantly more abundant in all the released cages when compared to $N$. tenuis and D. maroccanus. Conversely, $N$. tenuis was the most abundant at $27^{\circ} \mathrm{C}$. These trends linked to temperature are in accordance with the observations made 
by Sánchez et al. (2003), who reported that M. pygmaeus was more abundant than $N$. tenuis in the spring and early summer in horticultural crops in inland areas of South-eastern Spain, whereas N. tenuis was the predominant species found naturally in the coastal areas where temperatures were higher. Previous studies confirmed that $N$. tenuis is more thermophilous than any of the other Dicyphinae members, such as M. pygmaeus, M. caliginosus Wagner, and D. tamaninii Wagner (Hemiptera: miridae) (Sánchez et al., 2009). The optimum temperature required by $N$. tenuis ranges between 20 and $30{ }^{\circ} \mathrm{C}$, with a high fertility rate observed at $30{ }^{\circ} \mathrm{C}$, that allows this mirid better adaptation to high temperatures (Sánchez et al., 2009; Hughes et al., 2009, 2010). Indeed, in this research we observed how $N$. tenuis was able to double its population at $27^{\circ} \mathrm{C}$.

Temperature is not the only factor that could have influenced the distinct development of the mirids. The availability of prey could also have influenced the population dynamics obtained. Prey scarcity was more evident at $20^{\circ} \mathrm{C}$, especially in the case of B. tabaci, which is better adapted to higher temperatures (Bonato et al., 2007; Naranjo et al., 2010). Macrolophus pygmaeus can continue its immature development by feeding exclusively on the plant tissue although its survival is highly affected (Perdikis and Lykouressis, 1996, 2000; Portillo et al., 2012). However, N. tenuis is prey dependent (Urbaneja et al., 2005), which could have accentuated the thermal differences between both species even more. Prey preference and switching behaviour to feeding on the most preferred prey are additional characters to be considered when evaluating the potential of polyphagous predators in multi-pest agroecosystems. However, in the case of Hemipteran predators, developmental rate and fecundity are usually enhanced when they are fed multi-prey diets (Wheeler, 2001), which may indicate that even 
in the case of strong preferences for one prey, the necessity to diversify the diet can be very influential. Mixed diets are known to have a positive effect on reproduction in some predator species (Evans et al., 1999). For example, in greenhouse cucumber, better control was achieved by the predatory mite A. swirskii due to the positive effect of a mixed diet of thrips and whiteflies (Messelink et al., 2008).

Macrolophus pygmaeus being slightly less abundant at $27{ }^{\circ} \mathrm{C}$ than at $20{ }^{\circ} \mathrm{C}$ was more effective at $27^{\circ} \mathrm{C}$ than at $20{ }^{\circ} \mathrm{C}$. The strong reduction in B. tabaci populations in the presence of F. occidentalis and vice versa could be due to an increased response by $M$. pygmaeus to higher prey availability (Holt, 1977; Holt and Lawton, 1994). Several previous studies support the idea of numerical responses by $M$. pygmaeus depending on the number of available prey (Fauvel et al., 1987; Alómar et al., 2002). In accordance with our results, Fantinou et al. (2008), observed an increase in the predation rate of $M$. pygmaeus on $M$. persicae at $30^{\circ} \mathrm{C}$ where the amount of susceptible prey was higher than at lower temperatures where the availability of prey was lower. The reasons for this shift in the predator's behaviour when foraging at higher temperatures may be related to increased metabolic rates and behavioural changes of the predator and/or prey, which could result in more successful predatory searches (lower search time) or less effective defence by the prey (Fantinou et al., 2008).

The third tested mirid species, D. maroccanus, failed to successfully establish throughout the length of the experiment at both temperatures studied. In previous studies, D. maroccanus was observed to successfully establish itself and prey on Tuta absoluta Meyrick (Lepidoptera: Gelechiidae) on tomato crops (Abbas et al., 2014), and on M. persicae on sweet pepper plants (Pérez-Hedo and Urbaneja, 2015). The reasons that could explain its failure 
to establish itself remain unclear, but perhaps thrips and whiteflies were not suitable prey species for this predator. As a result of the low abundance of D. maroccanus, neither of the two pests were adequately suppressed, despite the lower population levels of them when compared to the control cages. All the plants treated with D. maroccanus appeared unhealthy at the end of the experiment, with no visual differences observed between them and the control cages.

Our results are not the first to describe the efficiency of $N$. tenuis and M. pygmaeus in managing thrips and whiteflies; this has already been seen in several agricultural crops (Castañé et al., 1996; Riudavets and Castañé, 1998; Blaeser et al., 2004; Bonato et al., 2006; Sánchez and Lacasa, 2008; Calvo et al., 2012b; Malo et al., 2012). However, in the case of sweet pepper, this is the first study that evaluates the effectiveness of both mirids when pre-plant release was done without combining them with other natural enemies. Indeed, Calvo et al. (2009a) evaluated the potential predation of $N$. tenuis combined with that of the parasitoid, Eretmocerus mundus Mercet (Hymenoptera: Aphelinidae), and A. swirskii. In that study, the combined release of $N$. tenuis with $A$. swirskii did not improve the biological control of B. tabaci on sweet pepper. However, Messelink and Janssen (2014) confirmed the combination of M. pygmaeus and O. laevigatus to enhance the biological control of F. occidentalis and M. persicae in sweet pepper crops.

Overall, our results, together with those of previous studies (regarding the efficiency of mirids in managing aphids on sweet pepper, could help to develop new strategies for pest management in commercial sweet pepper crops using generalist predators. Moreover, the efficacy of $N$. tenuis and M. pygmaeus preying upon a mixed diet of sweet pepper pests including aphids warrants further research. Biological control agents are 
frequently used in combination; however, the success of a biological control program can be disrupted by direct and or indirect interactions, such as competition, apparent competition, intraguild predation, and behavioural interference, between natural enemies. Hence, we have planned a study on the compatibility of $N$. tenuis and M. pygmaeus with other natural enemies already adapted to sweet pepper, such as A. swirskii, to evaluate their combined efficacy in this crop. 


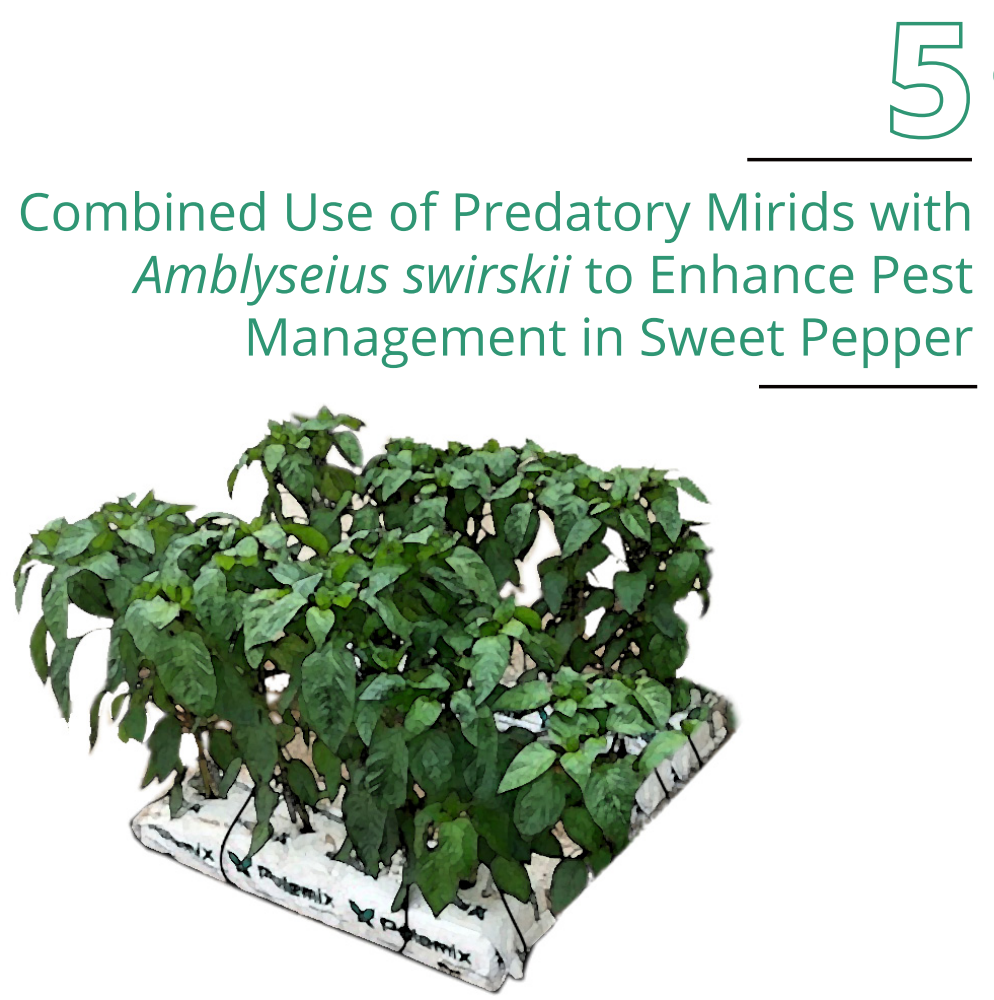



\title{
5 \\ Combined use of predatory mirids with Amblyseius swirskii to enhance pest management in sweet pepper
}

\author{
Sarra Bouagga, Alberto Urbaneja, Meritxell Pérez-Hedo \\ Journal of Economic Entomology, DOI: 10.1093/jee/toy072
}

\section{Abstract}

The combined release of Orius laevigatus with Amblyseius swirskii provides effective control of sweet pepper key pests, such as thrips and whiteflies. However, the management of the aphids can still be improved. Recently, the predatory mirids Nesidiocoris tenuis and Macrolophus pygmaeus have been found to be effective in the control of aphids, thrips and whiteflies when tested alone. Hence, integrating one of these two mirids with $A$. swirskii might enhance sweet pepper pest management. In this work, we began by investigating the co-occurrence of both mirid species when released together with $A$. swirskii. This was compared to the standard release of O. laevigatus with $A$. swirskii. Nesidiocoris tenuis and A. swirskii were involved in a bidirectional intraguild predation (IGP). On the contrary, this interaction (IGP) was apparently unidirectional in the case of $M$. pygmaeus with $A$. swirskii and O. laevigatus with $A$. swirskii. Both, M. pygmaeus and O. laevigatus significantly reduced the abundance of $A$. swirskii. Secondly, in a greenhouse experiment, where the same release combinations were tested (either N. tenuis, M. pygmaeus or O. laevigatus combined with $A$. swirskii), IGP seemed to be neutralized. Mirids with A. swirskii significantly suppressed thrips, whitefly and aphid infestations. Contrarily, the combined use of $O$. laevigatus with $A$. swirskii did not reached a satisfactory control for aphids, despite the reduction in thrips and whitefly densities. Therefore, our results suggest that the use of mirids combined with $A$. swirskii could result in more efficient and robust biological control programs in sweet pepper crops.

KeY words: Intraguild predation, Nesidiocoris tenuis, Macrolophus pygmaeus, Orius laevigatus, biological control. 


\subsection{Introduction}

Biological control (BC) programs, especially in greenhouse crops, are increasingly based on releases of several species of generalist predators against common greenhouse pests (Calvo et al., 2009a, 2012a; van Lenteren, 2012, van Lenteren et al., 2018). One of the most impressive success stories of BC was observed is sweet pepper crops in southeast Spain (Calvo et al., 2015). This success was achieved thanks to the combined release of the anthocorid bug Orius laevigatus Fieber (Hemiptera: Anthocoridae), and the predatory mite, Amblyseius swirskii Athias-Henriot (Acari: Phytoseiidae) which can control two important sweet pepper pests, the thrips species, Frankliniella occidentalis Pergande (Thysanoptera: Thripidae) and the whitefly Bemisia tabaci Gennadius (Hemiptera: Aleyrodidae). The release of O. laevigatus is mainly focused for controlling thrips, but when wellestablished it can also contribute to the management of whiteflies (Arnó et al., 2008), aphids (Alvarado et al., 1997), and spider mites (Venzon et al., 2002). Complementary, A. swirskii is released for controlling whiteflies (Nomikou et al., 2002; Calvo et al., 2009a) but it can also manage thrips (Messelink et al., 2006), broad mites (van Maanen et al., 2010) and to a lesser extent, spider mites (Messelink et al., 2010). In spite of the broad diet range of both predators, the BC system is still challenged due to aphids. The management of aphids requires the release of a combination of specialized parasitoids and predators (Blom, 2008; Messelink et al., 2011b, 2013). However, the abundance of hyperparasitoids in southeastern Spain (Belliure et al., 2008, Sánchez et al., 2011) and the interference occurring among generalist thrips predators and specialist aphid natural enemies (Messelink et al., 2011b), have negatively affected the outcomes of this BC program in sweet pepper. To make matters 
worse, the program can end up being extremely expensive (Messelink et al., 2011a).

In recent years a line of research to improve the $\mathrm{BC}$ of aphids has been focusing on identifying the generalist zoophytophagous predators able to be established in the sweet pepper crop prior to aphid arrival. This could result in rapid responses to new aphid infestations and would prevent aphid establishment (Messelink et al., 2011a). The effectiveness of zoophytophagous mirid predators (Hemiptera: Miridae) such as Macrolophus pygmaeus Rambur, Nesidiocoris tenuis Reuter, Dicyphus maroccanus Wagner and D. tamaninii Wagner has been explored in sweet pepper crops. Either, their inoculation or their release after pest outbreaks resulted in effective aphid management in this crop (Messelink et al., 2015; Pérez-Hedo and Urbaneja, 2015). In addition, some of these mirid species, such as $N$. tenuis and M. pygmaeus can also be effective to control whiteflies and thrips in sweet pepper under different temperatures (chapter 4). Therefore, the next step would be to know whether the pre-pest establishment of both species of mirids in sweet pepper could manage the populations of the three pests, whiteflies, thrips and aphids. For this, the combined use of either N. tenuis or M. pygmaeus and A. swirkii to reduce the populations of F. occidentalis, B. tabaci and Myzus persicae Sulzer (Hemiptera: Aphididae) was evaluated under greenhouse conditions. The contribution of $A$. swirskii, in the end, is currently so notably positive for BC in sweet pepper that a hypothetical use of mirids would inexorably be linked to the release of $A$. swirskii. Both alternative strategies were compared with the standard release of O. laevigatus and A. swirskii. 
Nonetheless, generalist zoophytophagous predators do not only feed on pests or plant-provided food, but also on other natural enemies (Rosenheim et al., 1995; Rosenheim, 1998). This feeding on other natural enemies can be classified as intraguild predation (IGP) when the competitors share prey and thus contend for it (Polis et al., 1989; Holt and Polis, 1997; Rosenheim et al., 1995). Therefore, the combined release of a pair of generalist predators could result in a negative outcome on $\mathrm{BC}$ of the target pest (Rosenheim et al., 1995; Rosenheim and Harmon, 2006; Janssen et al., 2006). As mentioned above, both predatory mirids and $A$. swirskii are true omnivores (Coll and Guershon, 2002) feeding on several trophic levels such as plant materials (pollen, nectar, plant sap), herbivores and other natural enemies, which can increase the probability of IGP. Indeed, Messelink et al. (2011b) showed that the predatory mite $A$. swirskii can seriously disrupt BC of aphids by preying on the eggs of the predatory midges, Aphidoletes aphidimyza Rondani (Diptera: Cecidomyiidae). Orius bugs can also prey on eggs and larvae of $A$. aphidimyza, and therefore act as an intraguild predator (Christensen et al., 2002). However, this outcome could also results positive for BC. Messelink and Janssen (2014), observed that IGP between M. pygmaeus and O. laevigatus did not affect BC of thrips and aphids, at contrary the combined augmentative release of both predator increased pest suppression.

Therefore, a laboratory experiment was conducted in order to study the interaction between predatory mirids and A. swirskii in combined release, in comparison to the standard release of O. laevigatus with $A$. swirskii. In this caged-experiment whether the intensity of IGP (if any) affects the abundance of the predatory bugs (N.tenuis, M. pygmaeus and O. laevigatus) or the predatory mite (A. swirskii) when co-occurring on sweet pepper plants provided or deprived of eggs of the shared prey, Ephestia kuehniella Zeller (Lepidoptera: 
Pyralidae) was studied. Then, under greenhouse conditions we evaluated the efficacy of each the mixed releases (N. tenuis with A. swirskii; M. pygmaeus with $A$. swirskii and O. laevigatus with $A$. swirskii) in reducing F. occidentalis, $B$. tabaci and $M$. persicae infestation in sweet pepper. Implications of these results for the future of $\mathrm{BC}$ of sweet pepper pests are discussed.

\subsection{Materials and Methods}

\subsubsection{Plants and insects}

The plants used in all experiments were pesticide free-sweet pepper seedlings [Capsicum annuum (Solanaceae)] cv ('Lipari') (Dulce italiano, Mascarell semillas S.L, Valencia, Spain). Two weeks after germination seedlings were transplanted in plastic pots $(8 \times 8 \times 8 \mathrm{~cm})$ containing a mixture of natural soil with local peat moss and were housed in a growth chamber at $25 \pm 2{ }^{\circ} \mathrm{C}, 60-80 \% \mathrm{RH}$ and $14: 10 \mathrm{~h}(\mathrm{~L}: \mathrm{D})$ photoperiod at the Instituto Valenciano de Investigaciones Agrarias (IVIA).

Nesidiocoris tenuis, M. pygmaeus, O. laevigatus and A. swirskii adults, were obtained from a commercial supplier (NESIBUG®, MYRICAL ${ }^{\circledR}$, THRIPOR®, SWIRSKI-MITE®, Koppert Biological Systems, S.L., Águilas, Murcia, Spain). Each predatory bug was provided in plastic bottles containing 500 adult individuals approximately 3-days-old (FJ Calvo, Koppert BS; Personal Communication). Amblyseius swirskii was supplied in bottle or in sachet according to the experimental requirements. Frozen E. kuehniella (Entofood®; Koppert B.S.) eggs were used as additional food to enhance mirids establishment in sweet pepper. Frankliniella occidentalis adults were obtained from a colony established at IVIA initiated in 2010 with 
individuals originally collected from Campo de Cartagena (Murcia, Spain). The thrips colony was reared on bean plants (Phaseolus vulgaris L.; Fabales: Fabaceae) and housed in a growth chamber at IVIA, at the same conditions mentioned above. The M. persicae (green phenotype) colony was obtained from a laboratory insect culture established on sweet pepper plants in IVIA, as described in Pérez-Hedo and Urbaneja (2015).

\subsubsection{Co-occurrence between predatory bugs and $A$. swirskii}

Under laboratory conditions, we studied the co-occurrence of predatory bugs' $N$. tenuis, M. pygmaeus, O. laevigatus and the predatory mite, A. swirskii on sweet pepper plants provided or deprived of E. kuehniella eggs. Four different treatments were assayed per predatory bug: 1) Predatory bug alone, 2) Predatory bug + E. kuehniella, 3) Predatory bug + A. swirskii and 4) Predatory bug $+A$. swirskii + E. kuehniella. In addition two treatments with A. swirskii were also conducted 1) A. swirskii alone and 2) A. swirskii + E. kuehniella. There were four replicates of each treatment. For this, 56 screened plastic cages (30 x 30 × 30 cm) (BugDorm-1 insect cages; MegaView Science Co., Ltd., Taichung, Taiwan) were maintained in a climatic chamber at IVIA (same conditions mentioned above). In each cage (replicate), one sweet pepper plant with 6 fully-developed leaves (approximately $15 \mathrm{~cm}$ in height) was placed inside. Two couples (male and female) of each predatory bug ( $N$. tenuis, M. pygmaeus or O. laevigatus) and $50 \mathrm{~A}$. swirskii individuals were released the same time. The number of adults and nymphs of each predatory bug species and the number of $A$. swirskii individuals (adults, protonymphs, deutonymphs and larvae) per plant was weekly recorded using a manual magnifying glass. The experimental period lasted six consecutive weeks. 


\subsubsection{Greenhouse efficacy experiment}

The experiment was carried out in a greenhouse equipped with drip irrigation system located at IVIA in Moncada (Valencia, Spain). The greenhouse was divided into 24 experimental cages with access through an isolating double mesh door. Cages were screened with "anti-thrips" polyethylene mesh of $220 \times 331 \mu \mathrm{m}$ interstices and had concrete floors. Each experimental compartment measured $4 \times 3 \times 3 \mathrm{~m}$ (length $\times$ height $\times$ width) and were equipped with five hydroponic substrate containers (growbag). Each cage was accessed by a separate door secured with a zipper.

The climatic conditions including temperature and relative humidity were recorded using a data-logger (model TESTO 175-H2, Amidata S.A. Pozuelo de Alarcón, Madrid), that was placed in the central cage. The average temperature during the experiment ranged between $24.9^{\circ} \mathrm{C}$ on May $4^{\text {th }}, 2016$ and $32.7^{\circ} \mathrm{C}$ on June 9,2016 with a minimum and maximum temperature of $21.1^{\circ} \mathrm{C}$ and $43.5^{\circ} \mathrm{C}$, respectively. The average relative humidity varied between $55.4 \%$ on May $4^{\text {th }}, 2016$ and $98.6 \%$ on June 9, 2016 with absolute minimum and maximum values of $33.7 \%$ and $99.7 \%$, respectively.

Four different treatments were considered: 1$) N$. tenuis $+A$. swirskii, 2) M. pygmaeus $+A$. swirskii, 3) O. laevigatus $+A$. swirskii and 4) control, without any predators released. Four replicates per treatment were made. Each replicate was assigned to one cage, hence 16 cages were used. The experiment started by inoculating sweet pepper seedlings in the nursery with either $N$. tenuis or $M$. pygmaeus at a release rate of one predator per plant (Fig.5.1). To help predator establishment and oviposition, frozen eggs of the factitious prey E. kuehniella, approximately $0.1 \mathrm{~g}$ per plant were supplied as alternative food (Urbaneja-Bernat et al., 2015). One week later, either inoculated 
or non-inoculated sweet pepper plants (depending on the treatment) were transplanted and moved to the greenhouse. In each cage, 20 plants were transplanted to hydroponic substrates at a rate of 4 plants per growbag. The day following transplantation one sachet of $A$. swirskii, containing around 125 mites of mixed ages, was hung on the first plant node on every three sweet pepper plant. One week after transplantation the infestation of the plants with weekly releases of F. occidentalis (5 adults $/ \mathrm{m}^{2}, 40$ adults/cage), B. tabaci (10 adults $/ \mathrm{m}^{2}, 80$ adults/ cage) and $M$. persicae (30 aphid of mixed age/plant) was initiated. Six releases were conducted for F. occidentalis and for B. tabaci. In the case of M. persicae only three releases were made due to the rapid proliferation of aphids in the control treatment. These release rates and their frequency were chosen to simulate a strong and early pest attack. Four weeks after transplantation, sweet pepper plants began flowering and O. laevigatus individuals were released in the cages corresponding to "O. laevigatus + A. swirskii" treatment at the rate of 1 adult/plant. Two releases of O. laevigatus were done at an interval of 7 days. One week later the pest infestation samplings were initiated and continued until the end of the experiment which was 6 weeks later. For this, five random plants per cage were selected and the number of F. occidentalis, B. tabaci, M. persicae and the number of predators (immature and adults) per plants were recorded. Special care was always taken to count the replications in the control compartment first and then the cages with the predators to reduce risk of accidental contamination among treatments. The full experiment ran for nine weeks, from beginning of May to the end of June 2016. The experiment was stopped after the sixth data collection date due to the high attack in the control cages which resulted in the total collapse of the control plants. Plants were irrigated twice a week throughout the experiment. A graphical scheme summarizing the release calendar is shown in Fig.5.1. 
Mirids and A. swirskii against Sweet Pepper Pests
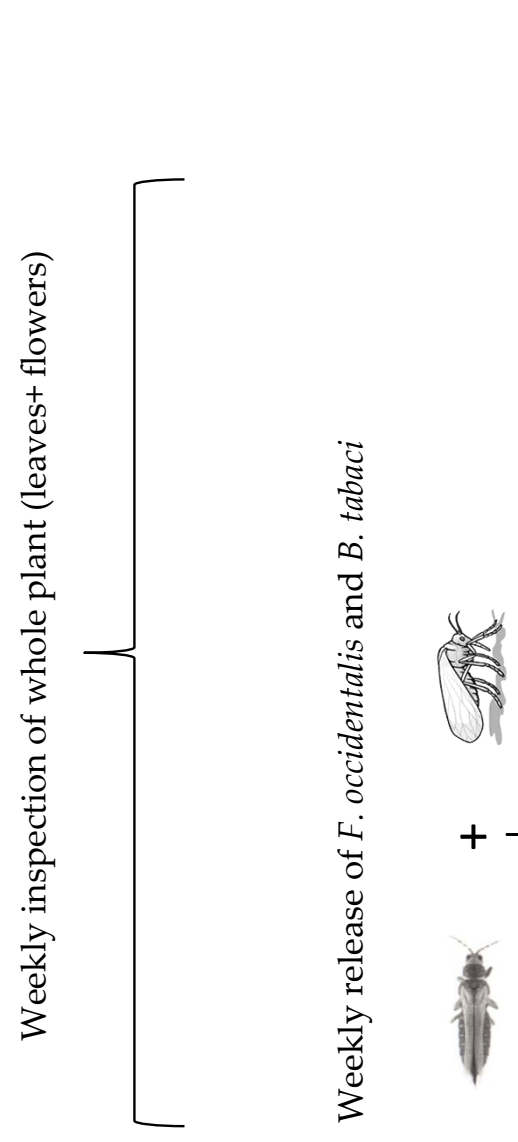


\subsubsection{Statistical analysis}

In the co-occurrence experiment, the accumulated number of predatory bugs (adults + nymphs) and predatory mites (nymphs, protonymphs, deutonymphs and adults) during the course of the trial were calculated. The resulting estimates of insect per days (=area under the weekly incidence curve) was log transformed and then subjected to a one-way analysis of variance (ANOVA) joined with a Tukey's test for mean separation $(\alpha<0.05)$. Treatments with zero values during the 6 weeks of the analysis were excluded from the analysis. Therefore, in $N$. tenuis treatment, one-tailed Student's $t$-test $(P<0.05)$ was conducted since only two treatments were compared. For the greenhouse experiment, the total number of F. occidentalis, B. tabaci, M. persicae and predators per sweet pepper plants were $\log (x+1)$ transformed prior to analysis using the generalized Linear Mixed Models (GLMM). Treatment was considered to be a fixed factor and time (weeks) as a random one. Each GLMM used a normal distribution and identity link function. Whenever a significant difference was found, pairwise comparisons of the fixed factor levels were performed with the least significant difference (LSD) post-hoc test $(P<0.05)$. Untransformed value are presented in figures. To calculate F. occidentalis, B. tabaci and $M$. persicae percentage of reduction, Abbott's formula was applied, $100 \times$ [1- (treated/control)] (Abbott, 1925) using the accumulated number of F. occidentalis, B. tabaci and M. persicae. To know whether differences between the percentages of reduction existed, data were $\log$ transformed and then a one way ANOVA followed by comparison of means (Tukey's test) at $P<0.05$ was conducted. The results were expressed as the means \pm standard error. 


\subsection{Results}

5.3.1. Dynamics of predatory bugs when co-occurred with $A$. swirskii

The population dynamics of the three predatory bugs was significantly different among the four release treatments (released alone, released together with $A$. swirskii, released with the addition of E. kuehniella eggs and released together with $A$. swirskii with the addition of E. kuehniella eggs (N. tenuis: $t_{1,7}=2.51, P=0.046 ; M$. pygmaeus: $F_{3,15}=296.8, P<0.001$ and O. laevigatus: $F_{2,11}=230.7 P<0.001$ ) (Fig.5.2). The highest population density for the three predators was observed in treatments receiving E. kuehniella eggs as additional food. Both $N$. tenuis and O. laevigatus were unable to survive and reproduce in the absence of E. kuehniella eggs. Nevertheless, M. pygmaeus was able to survive 7 weeks after its release on sweet pepper plants deprived from alternative prey, although at a very low density (Table 5.1; Fig.5.2). When predatory bugs were released together with the predatory mite on those plants provided with the addition of E. kuehniella eggs, N. tenuis significantly decreased its population density (Fig.5.2.a). However, the density of O. laevigatus and M. pygmaeus was not negatively affected when released with $A$. swirskii in the presence of E. kuehniella eggs (Figs.5.2.b,c). 
(a)

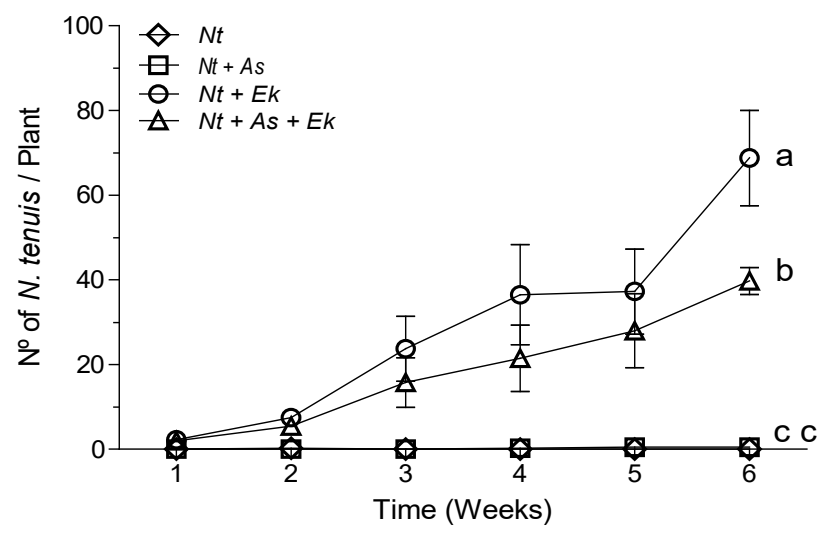

(b)

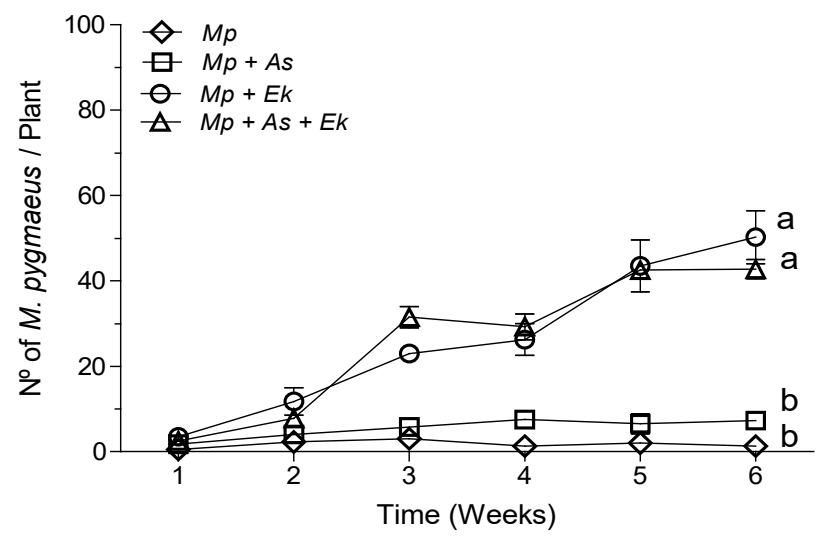

(c)

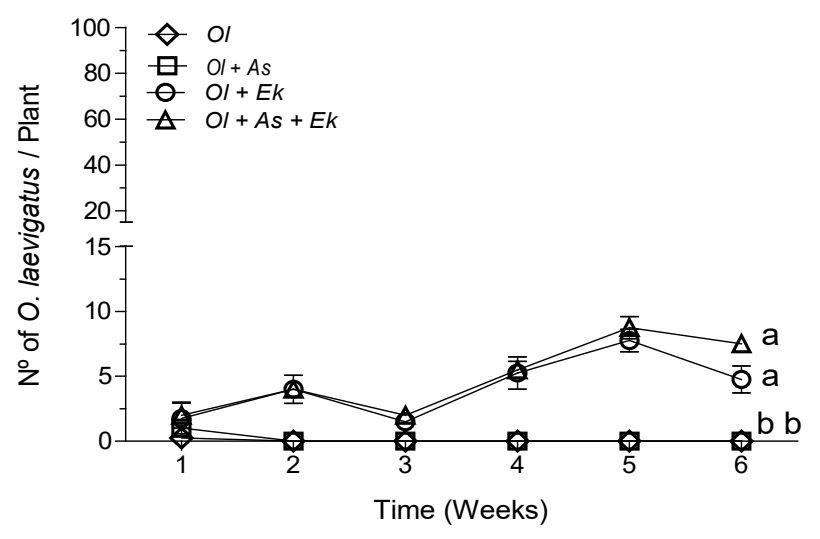

Figure 5.2.

Variation in the abundance of predatory bug (a) N. tenuis (Nt), (b) M. pygmaeus (Mp) and (c) O. laevigatus (O/) (adults + nymphs, mean number \pm SE) per sweet pepper plant in single species treatment and in mixed treatment with $A$. swirskii (As) when the shared prey E. kuehniella (Ek) eggs were and were not provided. Different letters indicate significant differences of predator bug numbers of the same species between treatments. 
Mirids and A. swirskii against Sweet Pepper Pests

$5 \mid \frac{\substack{\frac{1}{0} \\ \frac{0}{0}}}{\frac{D}{\frac{1}{2}}}$

$\frac{c}{\frac{c}{2}} \frac{\mathfrak{c}}{3}$

ते

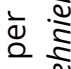

일

证

हे बे

䓀

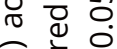

峲 $\frac{1}{\sigma} v$

$\pm \stackrel{4}{\infty}$

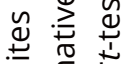

E

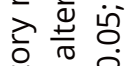

苛

능 ते

믐

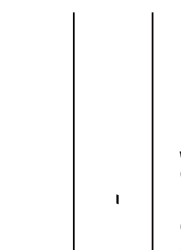

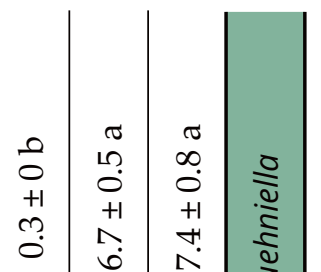

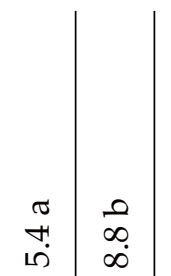

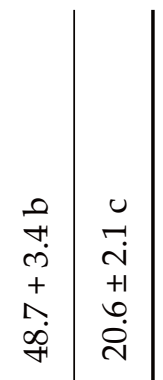

Ш

山 $\frac{1}{2}$

世

जิ

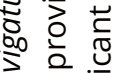

흔 는

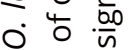

जั 잉

จ 는

은 는

टे 인

之诘

जิ

ฐ

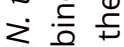

ज ह 즈

ำ 억 임

글

중 $\frac{5}{3}$ 음

哉

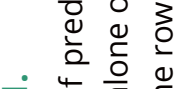

둥

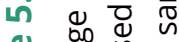

(1)

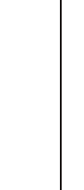

$\begin{array}{cc}0 & 0 \\ & 0 \\ 0 & 0 \\ +1 & +1 \\ & 0\end{array}$

m 10.000

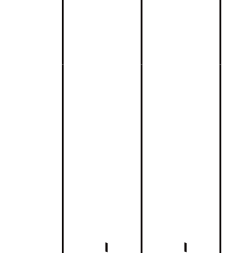

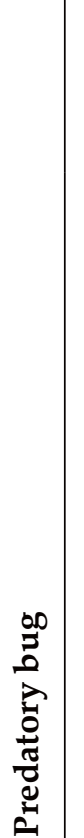

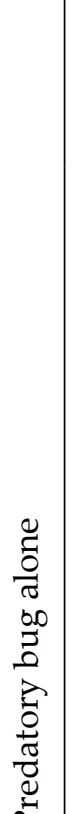

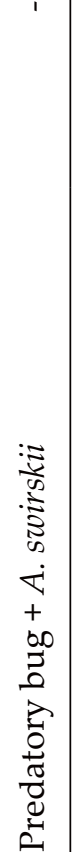

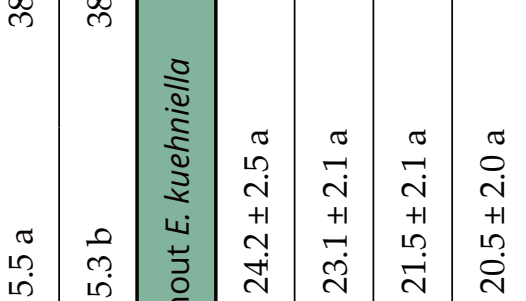

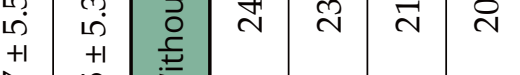

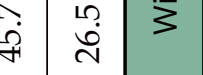

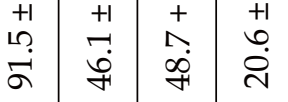

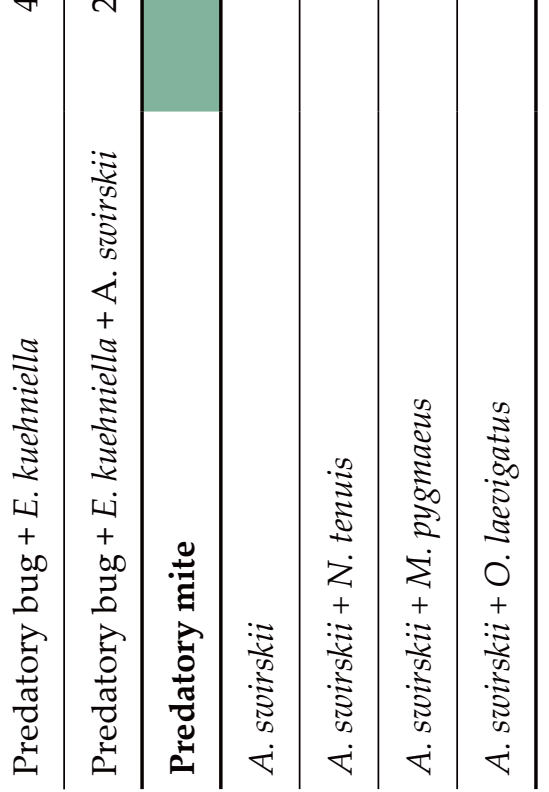




\subsubsection{Dynamics of $A$. swirskii when co-occurred with predatory bugs}

The number of $A$. swirskii per plant was not different when comparing the population dynamics of the treatment where $A$. swirkii was released alone with the population dynamics of those treatments where $A$. swirskii was released with one of the three predatory bugs tested $\left(F_{3,15}=0.52, P=0.68\right)$ (Fig.5.3.a). In spite the general trend, the populations of $A$. swirksii decreased from the date they were released. This predatory mite was able to survive in the sweet pepper plants without access to prey during the 7 weeks of the experiment, independent of the presence or absence of a predatory bug. Nevertheless, the population dynamics of $A$. swirskii were significantly different between the four treatments where the releases of $A$. swirskii were supplemented with eggs of E. kuehniella $\left(F_{3,15}=24.02\right.$, $P<0.001$ ) (Fig.5.3.b). The combined release of any of the three predatory bugs with $A$. swirskii in the presence of E. kuehniella significantly reduced $A$. swirskii populations when compared to the treatment when $A$. swirskii was released with E. kuehniella alone. Indeed, the combined release with O. laevigatus was the one that was significantly more detrimental for the phytoseiid populations (Fig.5.3.b).
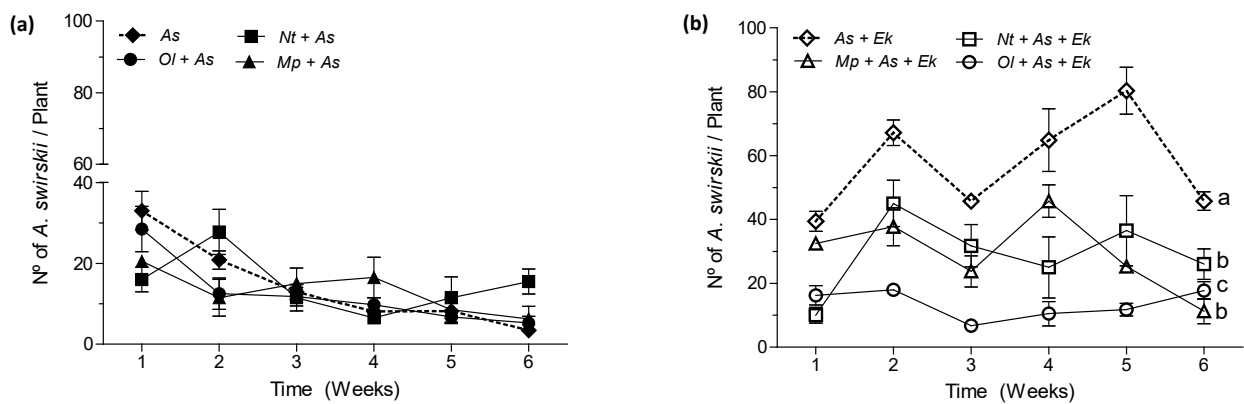

Figure 5.3.

Variation in the abundance of $A$. swirskii (As) (adults + deutonymph + protonymph + nymphs, mean number \pm SE) per sweet pepper plant in single specie treatment and in mixed treatment with predatory bugs when the shared prey E. kuehniella (Ek) eggs were (a) and were not provided (b). Different letters indicate significant differences of $A$. swirskii numbers between treatments. 


\subsubsection{Predators abundance under greenhouse conditions}

The three predatory bugs established themselves on sweet pepper plants when released together with $A$. swirskii and remained active until the end of the experiment, although significant differences were observed among their abundances $\left(F_{2,69}=13.10, P<0.001\right)$ (Fig.5.4.a) (Table 5.2). Nesidiocoris tenuis was significantly the most abundant predator in comparison to the number reached by M. pygmaeus and O. laevigatus (Table 5.2; Fig.5.4.a). On the contrary, the number of $A$. swirskii per plant was similar when released in a mixed treatment with either $N$. tenuis, M. pygmaeus or O. laevigatus $\left(F_{2,69}=1.90 ; P=0.16\right)$ (Table 5.2; Fig.5.4.b). However, it should be mentioned that the number of $A$. swirskii per plant was abruptly reduced after the release of O. laevigatus (Fig.5.4.b), although when compared to the number of $A$. swirskii in the other two predatory bug treatments, no differences were found.

\section{Table 5.2.}

P-values for the pairwise comparison of the number of $A$. swirskii (As) and predatory bug (O. laevigatus, N. tenuis, M. pygmaeus) per sweet pepper plant in the following treatments (N. tenuis + A. swirskii $(N t+A s)$, M. pygmaeus $+A$. swirskii $(M p+A s)$ and O. laevigatus $+A$. swirskii $(O /+A s)$ ). Values in bold correspond to significant differences between treatments.

\begin{tabular}{lcccc}
\hline Treatments & \multicolumn{2}{c}{ Predatory mite } & \multicolumn{2}{c}{ Predatory bug } \\
\cline { 2 - 5 } & $t_{69}$ & $P$ & $t_{69}$ & $P$ \\
\hline$N t+A s$ vs $M p+A s$ & 0.31 & 0.76 & 3.50 & $\mathbf{0 . 0 0 1}$ \\
\hline$N t+A s$ ss $\mathrm{Ol}+A s$ & 1.50 & 0.14 & 4.98 & $<0.001$ \\
\hline$M p+A s$ vs $\mathrm{Ol}+A s$ & 1.82 & 0.07 & 1.48 & 0.14 \\
\hline
\end{tabular}




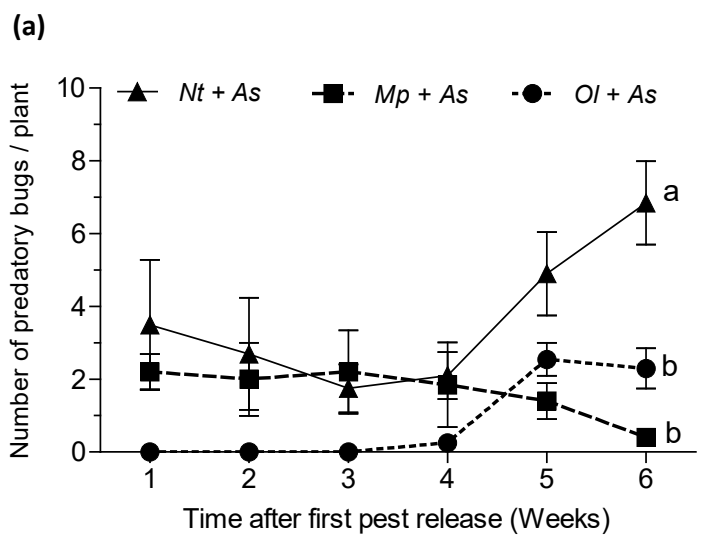

(b)

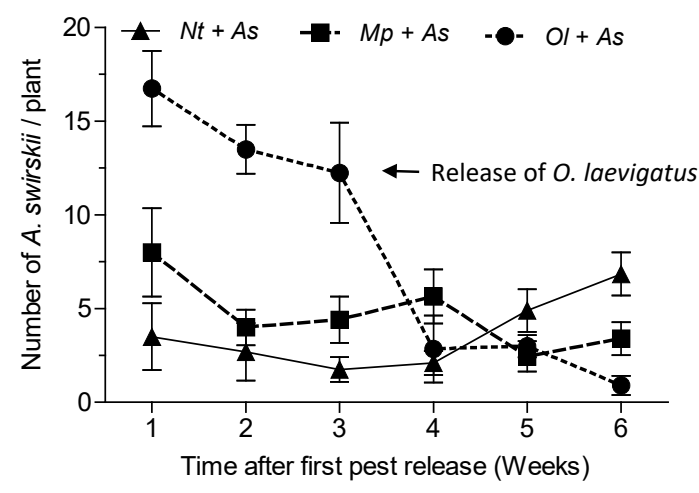

Figure 5.4.

(a) Dynamics of the predatory bugs' $N$. tenuis $(N t), M$. pygmaeus $(\mathrm{Mp})$ and $\mathrm{O}$. laevigatus $(\mathrm{O} /)$ (adults + nymphs, mean number \pm SE) per sweet pepper plant when released combined with $A$. swirskii. (b) Dynamics of $A$. swirskii (As) (adults + deutonymph + protonymph + nymphs, mean number $\pm \mathrm{SE}$ ) per sweet pepper plant in different combined treatments with predatory bugs under greenhouse experimental conditions. Different letters indicate significant differences of predators' numbers between treatments.

\subsubsection{Pest management}

The number of F. occidentalis per sampled plant was continuously suppressed at significant levels in the three treatments which received releases of predators $(\mathrm{Nt}+\mathrm{As}, \mathrm{Mp}+\mathrm{As}$ and $\mathrm{Ol}+\mathrm{As})$ when compared to the control $\left(F_{3,92}=13.66 ; P<0.001\right)$ (Table 5.3; Fig.5.5.a). The infestation by F. occidentalis was significantly reduced to $97 \%, 95 \%$ and $75 \%$, in the $N t+A s$, $\mathrm{Mp}+A s$ and $\mathrm{Ol+As}$ treatments, respectively, without differences between 
them (Fig.5.5.b). In a similar way, B. tabaci was significantly reduced in the three treatments with predator releases $(\mathrm{Nt}+\mathrm{As}, \mathrm{Mp}+\mathrm{As}$ and $\mathrm{Ol}+\mathrm{As})$ when compared to the control $\left(F_{3,92}=22.475 ; P<0.001\right)$ (Table 5.3; Fig.5.5.c). The percentage of whitefly reduction was not significantly different between treatments and was 95\%,82\% and $89 \%$ in $\mathrm{Nt}+\mathrm{As}, \mathrm{Mp}+\mathrm{As}$ and $\mathrm{Ol}+\mathrm{As}$ treatments, respectively (Fig.5.5.d). Aphid densities significantly differed among treatments $\left(F_{3,92}=15.66 ; P<0.001\right)$ (Table 5.3). Sweet pepper plants managed with either $\mathrm{Nt}+\mathrm{As}$ or $\mathrm{Mp}+\mathrm{As}$, harbored significantly lower density of aphids when compared to $\mathrm{Ol}+\mathrm{As}$ and to the control. The abundance of aphids was also significantly lower in $\mathrm{Ol}+A s$ when compared to the control (Fig.5.5.e). Aphid infestation was significantly reduced in $N t+A s(90 \%)$ and $\mathrm{Mp}+\mathrm{As}(77 \%)$ in comparison to $\mathrm{Ol}+\mathrm{As}$ (35\%) (Fig. 5.5.f).

\section{Table 5.3.}

P-values for the pairwise comparison of the number of $F$. occidentalis, B. tabaci and M. persicae per sweet pepper plant that received a release of $N$. tenuis $+A$. swirskii $(N t+A s)$, M. pygmaeus $+A$. swirskii $(M p+A s)$, O. laevigatus $+A$. swirskii $(O /+A s)$ and control without release (C). Values in bold correspond to significant differences between treatments.

\begin{tabular}{|c|c|c|c|c|c|c|}
\hline \multirow[t]{2}{*}{ Treatments } & \multicolumn{2}{|c|}{ Frankliniella occidentalis } & \multicolumn{2}{|c|}{ Bemisia tabaci } & \multicolumn{2}{|c|}{ Myzus persicae } \\
\hline & $t_{92}$ & $P$ & $t_{92}$ & $P$ & $t_{92}$ & $P$ \\
\hline$C$ vs $N t+A s$ & 5.37 & $<0.001$ & 6.54 & $<0.001$ & 6.36 & $<0.001$ \\
\hline$C$ vs $M p+A s$ & 5.55 & $<0.001$ & 6.80 & $<0.001$ & 4.60 & $<0.001$ \\
\hline $\mathrm{C} v \mathrm{Ol}+\mathrm{As}$ & 4.54 & $<0.001$ & 6.76 & $<0.001$ & 2.03 & 0.04 \\
\hline$N t+A s$ vs $M p+A s$ & 0.18 & 0.85 & 0.26 & 0.80 & 1.77 & 0.08 \\
\hline $\mathrm{Nt}+\mathrm{As} v \mathrm{~s} \mathrm{Ol+As}$ & 0.82 & 0.41 & 0.23 & 0.82 & 4.33 & $<0.001$ \\
\hline $\mathrm{Mp}+\mathrm{As}$ vs $\mathrm{Ol}+\mathrm{As}$ & 1.00 & 0.312 & 0.03 & 0.97 & 2.55 & 0.01 \\
\hline
\end{tabular}


(a)

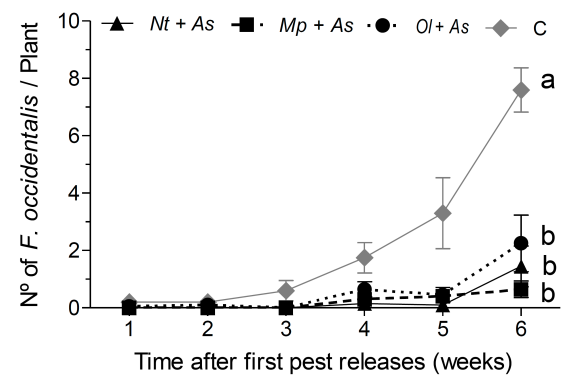

(c)

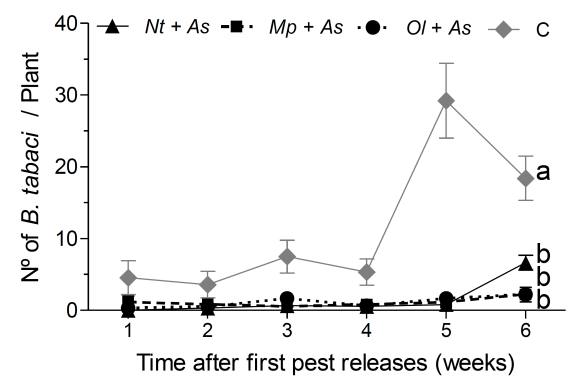

(e)

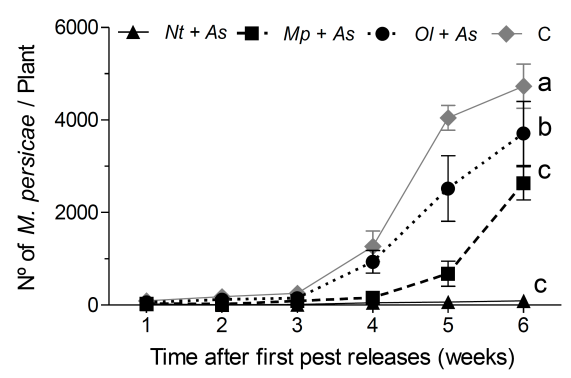

(b)

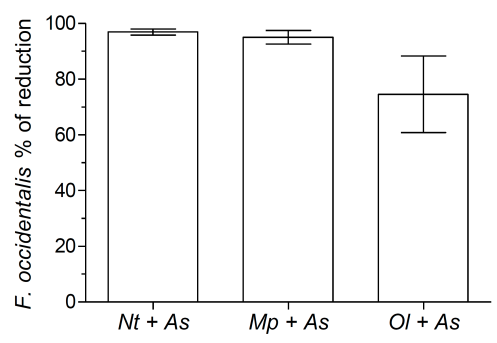

(d)

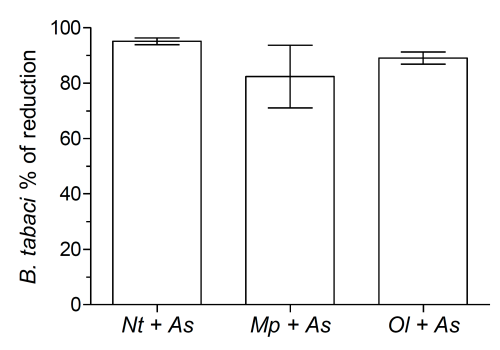

(f)

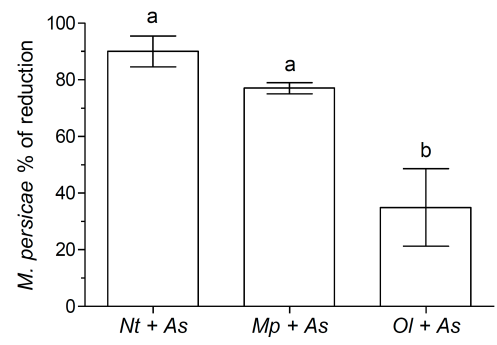

Figure 5.5.

(a) Number (mean $\pm \mathrm{SE}$ ) of $F$. occidentalis (adults + nymphs) per sweet pepper plant, (b) percentage reduction (Abbott) (mean $\pm \mathrm{SE}$ ) of $F$. occidentalis individuals (c) Number (mean $\pm \mathrm{SE}$ ) of $B$. tabaci (adults + nymphs) per sweet pepper plant, (d) percentage reduction (Abbott) (mean $\pm \mathrm{SE}$ ) of $B$. tabaci individuals, (e) Number (mean $\pm \mathrm{SE}$ ) of M. persicae (adults + nymphs) per sweet pepper plant, (f) percentage reduction (Abbott) (mean $\pm \mathrm{SE}$ ) of $M$. persicae individuals in a greenhouse experiment comparing the effectiveness of predatory bug ( $N$. tenuis $(N t)$, M. pygmaeus ( $M P$ ) and O. laevigatus (O/)) when released in mixed treatment with $A$. swirskii (As) each, at different time intervals. Bars with different letters are significantly different (ANOVA, Tukey's multiple comparison test $a<0.05$ ). 


\subsection{Discussion}

Under laboratory conditions, sweet pepper plants maintained M. pygmaeus at a very low developmental level during approximately two months. In contrast, $N$. tenuis and O. laevigatus were not able to build up a significant population when prey was absent on the plant. The ability of M. pygmaeus to continue its immature development by feeding exclusively on plant tissue is already known (Perdikis and Lykouressis, 2000; Portillo et al., 2012), while N. tenuis is prey dependent (Urbaneja et al., 2005) and O. laevigatus survival and reproduction are dependent on the presence of either prey or pollen (Cocuzza et al., 1997). Interestingly, we observed that even when one of the three predatory bugs co-existed on the same plant with A. swirskii, despite the need of $N$. tenuis and O. laevigatus for a protein source, the three predators ignored the predatory mite and vice versa. On the contrary, when E. kuehniella eggs were provided as a shared prey, only $N$. tenuis was negatively affected by $A$. swirskii. The population levels of $A$. swirskii were negatively affected by the three predatory bugs and significantly more affected by the presence of $O$. laevigatus than that the presence of mirids (Fig.5.3.b). Urbaneja et al. (2003) previously observed O. laevigatus preying on Neoseiulus cucumeris Oudemans (Acari: Phytoseiidae) in sweet pepper greenhouses. Because N. cucumeris was released in large quantities in a period of prey scarcity, prior to the release of O. laevigatus, these authors pointed out that the availability of $N$. cucumeris (intraguild prey) facilitated the establishment of $O$. laevigatus (intraguild predator). In our experiment, it seems that when E. kuehniella eggs were provided as shared prey, which is a high quality food for both of the predatory bugs (Cocuzza et al., 1997; Castañé et al., 2006) and the predatory mite (Nguyen et al., 2014), competition 
occurred. However, reasons why A. swirskii only negatively affected the stability of $N$. tenuis is still an open question.

Intraguild predation among predators is widespread and both unidirectional and bidirectional. IGP appears to be common and associated with natural enemies used in greenhouse production systems (Rosenheim et al., 1995). Based on theory, IGP is not expected to benefit BC (Rosenheim et al., 1995), and could be a determining factor in the abundance and distribution of BC agents (Lucas and Alómar, 2001; Perdikis et al., 2014). However, in practice, results are diverse and the potential risk of IGP disrupting BC appears to be low in many cases (Janssen et al., 2006; Messelink and Janssen, 2014). This is also the case of the current study, where, despite being involved in IGP, the mixed release of $N$. tenuis and A. swirskii, which were involved in a bidirectional IGP in the laboratory experiment, was virtually the best combination in the suppression of thrips, whiteflies and aphids under our greenhouse conditions. Availability and variability of prey (thrips, whiteflies and aphids) and food provided by the plant (pollen, nectar, plant sap) might be the reason for this non-aggressive coexistence. Indeed, an increase in extraguild prey density has been suggested to decrease the likelihood of predation events occurring among members of the predator guild (Polis et al., 1989, Lucas et al., 1998; Holt and Huxel, 2007). The within plant distribution and patch occupation by both predators, might have also reduced the encounter rate. Amblyseius swirskii on sweet pepper is generally found on the tuft domatia of the vein axils, a special structure of the sweet pepper leaves, which constitute a refuge for this mite and therefore might reduce the intensity of IGP under field conditions (Walter, 1996; Schmidt, 2014). The treatment involving M. pygmaeus with $A$. swirskii was as effective in pest suppression as $N$. tenuis with $A$. swirskii, however M. pygmaeus was 
significantly less abundant than $N$. tenuis. It is well known that M. pygmaeus is less thermophilous than N. tenuis (Sánchez et al., 2009), hence the high temperatures registered (mean of $30^{\circ} \mathrm{C}$ ) during the experimental period could have hampered the development of this predator. The combined release of $O$. laevigatus with $A$. swirskii successfully reduced F. occidentalis and B. tabaci populations at levels similar to those that provided treatments based on predatory mirids. However, in the cages that received the combined release of O. laevigatus and A. swirskii, aphids were far from being controlled, which resulted in the collapse of all the plants.

In this experiment, we adopted the pre-plant release strategy for mirids suggested by Calvo et al. (2012b) for tomatoes. This strategy is widely used today in greenhouse tomato crops in Southeastern Spain (Pérez-Hedo and Urbaneja 2016; Pérez-Hedo et al., 2017a). At transplantation, mirids had already laid eggs and the establishment was easier thanks to their ability to feed on plant tissue along with the addition of E. kuehniella eggs.

Overall, in order to extrapolate our experimental conditions to field conditions the availability of prey must be high. This high availability of prey is necessary to maintain the population of the mirids after their pre-plant release. In this sense, this strategy could be valid for summer plantings when the level of prey is high when the transplant occurs. However, in late winter plantations where prey availability is low, it is necessary to supplement the pre-plant release of mirids with the alternative food source. This could possibly make the system more expensive. In any case all these conditions have to be evaluated before making a decision regarding the use of mirids under true field conditions.

In conclusion, our study provides further evidence that the release of natural enemies involved in IGP does not necessary have negative effects 
on BC. Additional success by mirids in managing sweet pepper pests was confirmed throughout this study. Together with the newly discovered ability of predatory mirids to induce plant defence (Bouagga et al., 2017, 2018), we expect the future BC of sweet pepper in commercial greenhouse could rely on the release of $A$. swirskii with predatory mirids. What is clear is, the use of mirids in sweet pepper is possible and can be more effective than the current system based on O. laevigatus, which motivates us to suggest that mirids deserve more attention in the BC of sweet pepper pests. 


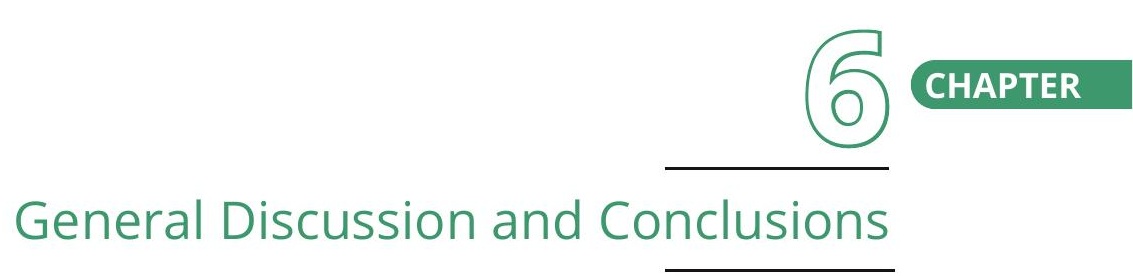





\section{6 \\ General Discussion and Conclusions}

The awareness of $\mathrm{BC}$ as a principle strategy for managing sweet pepper pests has increased tremendously in Spanish greenhouses. Since 2007, the willingness of consumers to pay for pesticide free fresh produce and the restrictive legislation minimising the number of authorised chemical products has resulted in a shift from insecticide use to the implementation of integrated pepper management programs based on the introduction of natural enemies in an extensive area (Blom et al., 2008; Calvo et al., 2009a, 2012a; van Lenteren, 2012). This shift was quick, subsequently BC in sweet pepper became outstandingly successful thanks to the selection and release of BC agents native to the Mediterranean basin. Nowadays, in South-eastern Spanish sweet pepper greenhouses the use of the anthocorid bug O. laevigatus and the phytoseiid predatory mite $A$. swirskii is done in augmentative releases to control the key pests, thrips and whiteflies (Blom et al., 2008; Calvo et al., 2012a; Calvo et al., 2015).

Omnivorous predators, including O. laevigatus, are known to supplement their carnivorous diet by plant feeding, consuming sap, pollen, and nectar (Cocuzza et al., 1997; Armer et al., 1998; Lundgren et al., 2008). Feeding on a wide range of prey was widely described for O. laevigatus. The piercing-sucking mouth parts allow the predator to inject saliva into a prey substrate by a specialized salivary canal in an elongated maxillary stylet. Salivary components pierce and liquefy the solid substrates of its prey before ingestion through the maxillary food canal (Walker, 2003). 
Studying gene expression in the salivary glands of O. laevigatus Baek and Lee (2014), determined the presence of a hemolysin-like protein known to destruct cells; digestive enzymes and antimicrobial proteins were also identified. Genes related to homeostasis, antioxidation, anticoagulation and neuropeptide or peptide hormone processing were also found to be transcribed in the salivary gland, likely facilitating O. laevigatus prey feeding. However, as mentioned above, O. laevigatus can also puncture the plant and inject its toxic saliva which consequently is expected to induce plant damages. In the second Chapter of this thesis, we showed plant feeding to be a common and important behaviour for O. laevigatus. We clearly observed how O. laevigatus inserts its stylet into sweet pepper tissue to pump out essential nutrients. This phytophagous behaviour was quantified (38\% of the observation time) and was classified as the preferred behaviour for this predator in both males and females in comparison to the rest of the activities which we also recorded during our observations. Consequently, our results concluded that mechanical damages caused by stylet insertion, perhaps with the injection of salivary secretion and regurgitates (Herbivore Associated Molecular Patterns, HAMPs) of O. laevigatus resulted in the induction of plant defences as those which generally occur in response to herbivore attacks (Karban and Baldwin, 1997; Kessler and Baldwin, 2001).

Against herbivores, plants deploy varying mechanism to overcome their attacks. Such defences can be displayed constitutively or can be induced. In general, constitutive defences are always present, and induced plant defences are activated by herbivory (Karban and Baldwin 1997; Kant et al., 2015). Omnivorous predators also induce plant defence thanks to their phytophagy behaviour; however, information describing this mechanism of defence is scarce. In this second chapter, using a test model consisting of 
sweet pepper plants, O. laevigatus, F. occidentalis, B. tabaci and the whitefly parasitoid, E. formosa, we observed that the exposure of sweet pepper plants to the activities (mainly feeding) of this predatory bug, increased resistance to sweet pepper pests directly by the up regulation of defensive genes (JA and SA pathways) and indirectly by the increased emission of HIPVs, which have modulated insects' behaviours. The volatile blends from O. laevigatuspunctured plants and intact sweet pepper plants differed quantitatively. This quantitative change constitutes a repellence effect for thrips and whiteflies, while an attraction for E. formosa. In plants the two major resistance mechanisms against herbivorous insects are antixenosis (interference with insect behaviour) and antibiosis (interference with insect physiology) (War et al, 2012). Here, for the first time we are confirming the phytophagous behaviour of $O$. laevigatus induce antixenosis in sweet pepper. This result reinforces and explains the potential use of O. laevigatus in sweet pepper greenhouse and illuminates how the predator efficiency is not only due to its predation, but also to its ability to induce plant defences. This novelty can be further explored to develop new approaches for pest management.

Despite the success of the current $\mathrm{BC}$ program in sweet pepper (combined release of O. laevigatus with A. swirskii against thrips and whiteflies) aphid management is still difficult to accomplish (Messelink et al., 2012). Therefore, much attention has been given during the last lustrum to find alternative natural enemies which could satisfy aphid management in this crop (Pérez-Hedo and Urbaneja, 2015; Messelink et al., 2015). Investigations focused on this theme stated how the use of mirid predators might significantly improve BC of aphids (Messelink et al., 2011a). Mirid predators combine zoophagy and phytophagy to complete their development and reproduction. Hence, with such predators, establishment can be prior to pest 
infestation. The highest density achieved by these kinds of predators before pest outbreak is key to their final successful use as BC agents (Arnó et al., 2010a, Urbaneja et al., 2012; Pérez-Hedo and Urbaneja, 2015; Messelink et al., 2015). In addition, mirid predators were recently observed to induce an ecological change in tomato after feeding. This change was described by Pérez-Hedo et al. (2015a, 2015b) as an induced defensive response in tomato plants and later on, confirmed by Pappas et al. $(2015,2016)$. In the third chapter of this thesis, we observed plant feeding to result in an important behaviour for $N$. tenuis and M. pygmaeus; this phytophagy habit elicits plant defence in sweet pepper. The quantification of plant feeding by both male and female predators turned out to be an important activity when compared to the rest of the described behaviours. Interestingly, we observed that $N$. tenuis (33\%) spent twice as much time feeding on sweet pepper than M. pygmaeus $(14 \%)$. However, both predators were able to induce plant injuries that activate the mechanisms of defence. Punctured sweet pepper plants by either $N$. tenuis or M. pygmaeus, resulted in activating the phytohormonal routes of ABA and JA. Similar results were recently obtained by Zhang et al. (2018); both phytohormones were accumulated in sweet pepper leaves exposed to $M$. pygmaeus. To further confirm plant defences, we have identified the HIPVs that produced sweet pepper following mirid feeding. The quantitative change in the blend of volatiles induced by either $N$. tenuis or M. pygmaeus incites plant resistance in punctured plants by modulating pest behaviour (attraction of E. formosa and repulsion of F. occidentalis and B. tabaci). The major differential peaks on the chromatogram of the volatile blend obtained from our results compared to the volatile blend recently obtained by Pérez-Hedo et al., (2017b) on tomato plants, concluded similarity in the response of both plants. Four GLV ((Z)-3-hexenol, (Z)-3-hexenyl 
acetate, (Z)-3-hexenyl propionate, (Z)-3-hexenyl butyrate) and methyl salicylate, were induced by both predators on both plants and interestingly were found to repel B. tabaci and attract E. formosa (Pérez-Hedo et al., 2017b). Methyl salicylate is one of the main components of the volatile blends released by damaged plants. It is well known that this compound can have repellent and deterrent effects on phytophages (Groux et al., 2014). Application of this compound on bean or cucumber leaves decreased the time spent by adult thrips on the lamina, reduced the number of eggs laid and the degree of damage (Koschier et al., 2007). Methyl salicylate is also reported to be a general attractant for natural enemies of pest species (James and Price, 2004; Mallinger et al., 2011; Gadino et al., 2012). Besides, quantitative changes in the volatile blend between mirid-punctured plants and intact plants, a qualitative change was also observed. Octyl-acetate was only emitted from M. pygmaeus-punctured plants. In accordance with our results, Pérez-Hedo et al. (2017b) detected octyl-acetate and characterized this volatile to be specific to M. pygmaeus, suggesting its possible contribution in the management of the tomato key pest, T. absoluta, in relation to previous results by the same authors, describing T. absoluta's reaction to M. pygmaeus-punctured tomato plants (Pérez-Hedo et al., 2015b). Overall, we concluded that new approaches for pest management can be explored from the obtained results. The use of powerful chemical pest repellents applied on the crop is an innovative approach that has not yet been properly investigated and certainly not developed into an effective commercial product. Establishment of natural enemy attractant dispensers in the areas of pest concentration would reduce predator search time and prevent the migration of the predator in the case of low prey density. This technique would probably increase the effectiveness of $\mathrm{BC}$ agents in the presence of the pest or preventively, 
before the appearance of the pest. It would be expedient to, both, find other highly attractive volatiles among the natural and synthetic compounds and to improve the methods of application of the most promising compounds. Another possible application of our results is the integration of plant breeding programs in selecting commercial varieties with higher emission rates of one of the most active volatile organic compounds. Among our results, we have observed that once sweet pepper is activated by the feeding punctures of $N$. tenuis, plants are still protected for a period of two weeks. With the feeding puncture of $M$. pygmaeus it was also observed perseverance of the effect during two weeks (Pappas et al., 2015). The persistence of this plant defence encourages the strategy of the pre-plant release (see below, chapter 4). Nursery inoculation will ensure plant robustness before pest outbreak and will delay the infestation due to the repellent effect.

Besides, the above described mechanism of plant defences induced by $N$. tenuis and M. pygmaeus, mirids are essentially predators, and have been successfully used for managing various pests (Urbaneja et al., 2012; Zappalá et al., 2012, 2013, Calvo et al., 2012b, 2012c; van Lenteren et al., 2018; Pérez-Hedo et al., 2017a). In particular, unlike other predatory bugs, the Orius genus is not hampered by glandular trichomes (Coll and Ridgway, 1995), tomato plants represent a very suitable host for mirids (Riudavet and Castañé, 1998; Tavella and Goula, 2001; Urbaneja et al., 2005). Therefore, inoculation with N. tenuis in Southern Europe and M. pygmaeus in Northern Europe and conservation of their natural populations have been very effective for controlling key tomato pests, including B. tabaci and T. absoluta (Arnó et al., 2010b; Calvo et al., 2012c; Gabarra et al., 2008; Gerling et al., 2001; Urbaneja et al., 2012). Unlike tomato, sweet pepper plants have smooth, waxy leaf surfaces with trichomes clustered in domatia only on the abaxial side 
(Ferreira et al., 2008); this lack of trichomes could be a disadvantage for hairy plant associated bugs like $N$. tenuis and M. pygmaeus and might explain the scarce use of mirids in sweet pepper crops (Tavella and Goula, 2001; Sánchez et al., 2003). However, even if sweet pepper is not the preferred host plant (Urbaneja et al., 2005), in the fourth chapter of this thesis, we have observed that $N$. tenuis and M. pygameus were successfully established on sweet pepper and effectively managed thrips and whiteflies. The strategy of the pre-plant releases or "predator in first" (Calvo et al., 2012b), enhanced by the addition of alternative food of the factitious prey E. kuehniella was crucial to ensure predator establishment and to assure an adequate predator: prey ratio which positively affects $B C$. However, provision of alternative food increases $\mathrm{BC}$ costs; the price of E. kuehniella fresh eggs is approximately $\$ 400$ per $\mathrm{kg}$ (Urbaneja-Bernat et al., 2015). Therefore, the development of inexpensive alternative food sources is one of the major opportunities and challenges for enhancing BC in greenhouse crops in the near future. Many artificial diets have been tested with the aim of developing less expensive mass rearing techniques (Castañé and Zapata, 2005; Bonte and de Clercq, 2008; Nguyen et al., 2013; Urbaneja-Bernat et al., 2015), but these diets are currently not applied to support predator populations in commercial crops. In addition to the importance of alternative diet in the success of mirids in sweet pepper, another criterion that should be considered during the selection of predators is the thermal requirement of each. Among the fourth chapter results, we have observed how $N$. tenuis was more abundant and more effective at a higher temperature (mean of $27^{\circ} \mathrm{C}$ ), whereas $M$. pygmaeus was more abundant at a cooler temperature (mean of $20^{\circ} \mathrm{C}$ ), but was still effective for both temperatures. Despite, the observed difference among predator abundance, both of them successfully reduced the mixed infestation of 
thrips and whiteflies. Macrlophus pygmaeus showed an interesting behaviour that could benefit its use as a BC agent. The low abundance of this predator at $27^{\circ} \mathrm{C}$ did not negatively affect the management of the mixed diet, on the contrary, we observed an increase in pest suppression. Overall, our results along with previous studies (Messelink and Janssen, 2014; Pérez-Hedo and Urbaneja, 2015; Messelink et al., 2015) expect the future of BC in sweet pepper to possibly be based on mirids. Paying special attention to mirid families may result in the selection of other efficient predators for the BC of horticulture crops. Although, we did not obtain encouraging results for the use of D. maroccanus in sweet pepper, many species from the genus Dicyphus are promising $\mathrm{BC}$ agents.

As we have seen above (chapters 2 and 3), N. tenuis and M. pygmaeus increase resilience in sweet pepper, both by inducing defensive responses and by predation. However, the best control strategies are mainly based on the combined releases of multiple natural enemies, the current success of the $\mathrm{BC}$ in sweet pepper (O. laevigatus and A. swirskii) attests this approach. Nevertheless, the use of different natural enemies for the $\mathrm{BC}$ of diverse pest species results in the creation of complex artificial food webs in agricultural crops. This implies how pest densities are not only managed by their natural enemies, but also by direct and indirect interactions with other pests and other natural enemies; thus, such interactions can affect BC (Rosenheim et al., 1995; Janssen et al., 1998). Intraguild predation (IGP) has been described for many natural enemies that are used for BC in greenhouse crops (Rosenheim et al., 1995). Although, in theory we do not expect IGP to benefit BC, several examples in the literature have mentioned lacks of negative effects (Janssen et al., 2006). In the fifth chapter of this thesis, this approach was supported and our results reveal that, despite being involved in a bidirectional 
IGP, the combined release of $N$. tenuis-A. swirskii under semi-field conditions resulted in a more effective suppression of thrips, whiteflies and aphids in sweet pepper. Among our results, we have also observed an apparently unidirectional IGP, where M. pygmaeus and O. laevigatus intraguild prey on A. swirskii when shared food (E. kuehniella) was added to the plant. Diverse results were obtained from laboratory and semi-field conditions. The population of $A$. swirskii was observed to be similar in the three mixed release combinations (predatory bugs with predatory mites). Possible coexistence between predatory bugs and predatory mites was resolved under field conditions by the availability of a mixed diet (thirps, whiteflies and aphids) and an increase in plant density which may have offered refuge and the avoidance of possible interactions among predators.

The infestation by thrips and whiteflies were effectively managed in the three treatments; however, where O. laevigatus-A. swirskii were released, aphids destroyed the plants and resulted in lower affectivity. Although, in the first chapter we observed O. laevigatus to induce plant defence in sweet pepper, we assume that the strategy employed in its release on flowering pepper may not benefit plants from the induced defence. One of the possible reasons is having plants which are already infested by herbivores that are also inducing plant defences. Thrips have a different feeding mode from whiteflies and aphids; hence, different defensive pathways are induced in the plant on which they feed (Wetering et al., 1998; Walling, 2008). Probably, the pathways induced by both feeding modes can negatively interfere with the pathways induced by O. laevigatus feeding or oviposition (De Puysseleyr, 2011) and the induced response will be suppressed. Howe and Jander (2008), mentioned that negative cross-talk between distinct defensive pathways induced by species from different feeding guilds might suppress the induced 
defence. On the contrary, in our experiment, mirids were released in the nursery, thus, upon planting, plants were already activated. The persistence of this activation (Chapter 3) motivated the defence response before pest outbreak; thus, delaying infestation which results in better management of pepper pest with either the inoculative release of $N$. tenuis or M. pygmaeus with $A$. swirskii. Specific temperature requirements of each predatory bug (Chapter 4) should also be considered for the use of mirids, because from our results, M. pygmaeus was less abundant than $N$. tenuis due to the higher registered temperature in the greenhouse (May-June, $30^{\circ} \mathrm{C}$ ).

According to the results presented in this PhD thesis, it can be concluded that pest management in sweet pepper could be enhanced by the exploitation of zoophytophagy. The anthocorid plant bug and mirids, are able to induce defence responses in sweet pepper plants. The information generated in this regard can serve as the basis for future developments in crop protection.

Overall, our results illustrate how mirids can be successfully employed in BC programs in sweet pepper. The results of this thesis support these conclusions: i) Their aptitude to establish on this crop is improved by supplemental food, ii) The safety of their feeding behaviour in sweet pepper is marked by the absence of economic damage, iii) The positive outcome of their phytophagous behaviour induces plant defence eliciting resistance mechanisms that reduce pest infestation, iv) Their polyphagy and their performance on managing sweet pepper key pests including thrips, whiteflies and particularly aphids and v) Their combined release with the predatory mite $A$. swirskii is without negative outcomes on the $\mathrm{BC}$ final balance. All together, these are sufficient reasons for an evaluation of mirids in commercial greenhouses that could rely on and reinforce their future commercial use in sweet pepper. 


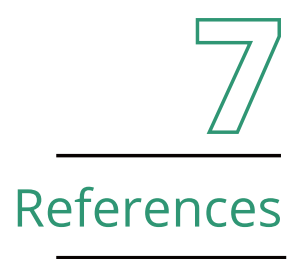





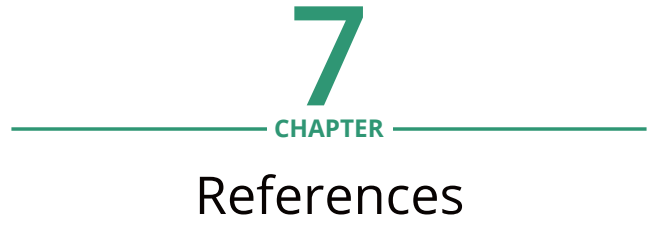

Abbas, S., Pérez-Hedo, M., Colazza, S., Urbaneja, A., 2014. The predatory mirid Dicyphus maroccanus as a new potential biological control agent in tomato crops. BioControl 59, 565-574.

Abbott, W.S., 1925. A method of computing the effectiveness of an insecticide. Journal of Economic Entomology 18, 265-267.

Abrams, P.A., 1987. The functional responses of adaptive consumers of two resources. Theoretical Population Biology 32, 262-288.

Agrawal, A.A., Fishbein, M., Jetter, R., Salminen, J.P., Goldstein, J.B., Freitag, A.E., Sparks, J.P., 2009. Phylogenetic ecology of leaf surface traits in the milkweeds (Asclepias spp.): chemistry, ecophysiology, and insect behavior. New Phytologist 183, 848-867.

Agrawal, A.A., Heil, M., 2012. Synthesizing specificity: multiple approaches to understanding the attack and defense of plants. Trends in Plant Science 17, 239-242.

Alba, J.M., Glas, J.J., Schimmel, B.C.J., Kant, M.R., 2011. Avoidance and suppression of plant defenses by herbivores and pathogens. Journal of Plant Interactions 6, 1-7.

Alba, J.M., Schimmel, B.C.J., Glas, J.J., Ataide, L.M.S., Pappas, M.L., Villarroel, C.A., Schuurink, R.C., Sabelis, M.W., Kant, M.R., 2015. Spider mites suppress tomato defenses downstream of jasmonate and salicylate independently of hormonal crosstalk. New Phytologist 205, 828-840. 
Alómar, O., Goula, M., Albajes, R., 2002. Colonisation of tomato fields by predatory mirid bugs (Hemiptera: Heteroptera) in northern Spain. Agriculture, Ecosystems \& Environment 89, 105-115.

Alómar, O., Riudavets, J., Castañé, C., 2006a. Macrolophus caliginosus in the biological control of Bemisia tabaci on greenhouse melons. Biological Control 36, 154-162.

Alómar, O., Gabarra, R., González, O., Arnó, J., 2006b. Selection of insectary plants for ecological infrastructure in Mediterranean vegetable crops. IOBC/WPRS Bulletin 29, 5-8.

Alvarado, P., Balta, O., Alomar, O., 1997. Efficiency of four heteroptera as predators of Aphis gossypii and Macrosiphum euphorbiae (Hom.: Aphididae). Entomophaga 42, 215-226.

Ardanuy, A., Albajes, R., Turlings, T.C.J., 2016. Innate and learned preysearching behavior in a generalist predator. Journal of Chemical Ecology 42, 497-507.

Arimura, G.I., Matsui, K., Takabayashi, J., 2009. Chemical and molecular ecology of herbivore-induced plant volatiles: proximate factors and their ultimate functions. Plant and Cell Physiology 50, 911-923.

Armer, C.A., Wiedenmann, R.N., Bush, D.R., 1998. Plant feeding site selection on soybean by the facultatively phytophagous predator Orius insidiosus. Entomologia Experimentalis et Applicata 86, 109-118. Arnó, J., Ariño, J., Español, R., Martí, M., Alomar, O., 2000. Conservation of Macrolophus caliginosus Wagner (Het. Miridae) in commercial greenhouses during tomato crop-free periods. IOBC/WPRS Bulletin 23, 241-246. 
Arnó, J., Roig, J., Riudavets, J., 2008. Evaluation of Orius majusculus and O. laevigatus as predators of Bemisa tabaci and estimation of their prey preference. Biological Control 44, 1-6.

Arnó, J., Castañé, C., Riudavets, J., Gabarra, R., 2010a. Risk of damage to tomato crops by the generalist zoophytophagous predator Nesidiocoris tenuis (Reuter) (Hemiptera: Miridae). Bulletin of Entomological Research 100, 105-115.

Arnó, J., Gabarra, R., Liu, T.X., Simmons, A.M., Gerling, D., 2010b. Natural enemies of Bemisia tabaci: predators and parasitoids. In: Stansly, P.A., Naranjo, S.E., (Eds.), Bemisia: bionomics and management of a global pest. Springer, Netherlands, Dordrecht, pp. 385-421.

Avilla, J., Albajes, R., Alomar, O., Castañé, C., Gabarra, R., 2004. Biological control of whiteflies in protected vegetable crop. In: Parrella, M.P., Heinz, K.M., (Eds.), Biological control of arthropods pests in protected culture. Ball Publishing, Batavia, IL, USA, pp. 171-184.

Baek, J.H., Lee, S.H., 2014. Differential gene expression profiles in the salivary gland of Orius laevigatus. Journal of Asia-Pacific Entomology 17, 729-735.

Baldwin, I.T., Schultz, J.C., 1983. Rapid changes in tree leaf chemistry induced by damage: Evidence for communication between plants. Science 221, 277-279.

Baldwin, I.T., 2010. Plant volatiles. Current Biology 20, 392-397.

Ballhorn, D.J., Kautz, S., Heil, M., 2013. Distance and sex determine host plant choice by herbivorous beetles. PLoS ONE 8, e55602.

Barbara, L.I., Marco, G. P., Tavella, L., 2011. Plant preference in the zoophytophagous generalist predator Macrolophus pygmaeus (Heteroptera: Miridae). Biological Control 58, 174-181. 
Bari, R., Jones, J.D.G., 2009. Role of plant hormones in plant defence responses. Plant Molecular Biology 69, 473-488.

Barratt, B.I.P., Moran, V.C., Bigler, F., van Lenteren, J.C., 2018. The status of biological control and recommendations for improving uptake for the future. BioControl 63, 155-167.

Bartels, D., Souer, E., 2004. Molecular responses of higher plants to dehydration. In: Hirt, H., Shinozaki, K., (Eds.), Plant responses to abiotic stress. Springer Berlin Heidelberg, Berlin, Heidelberg, pp. 9-38.

Bedoya-Pérez, M.A., Isler, I., Banks, P.B., McArthur, C., 2014. Roles of the volatile terpene, 1, 8-cineole, in plant-herbivore interactions: a foraging odor cue as well as a toxin? Oecologia 174, 827-837.

Belliure, B., Pérez, P., Marcos, M.A., Michelena, J.M., Hermoso de Mondaza, A., 2008. Control biológico de pulgones In: Jacques, J.A., Urbaneja, A., (Eds.), Control biológico de plagas agrícolas Phytoma España, Valencia, Spain.

Belda, J.E., Calvo, J., 2006. Eficacia de Amblyseius swirskii Athias-Henriot (Acari: Phytoseiidae) en el control biologico de Bemisia tabaci (Genn.) (Hom.: Aleyrodidae) y Frankliniella occidentalis (Pergande) (Thys.: Thripidae) en pimiento en condiciones de semicampo. Boletín de Sanidad Vegetal Plagas 32, 283-296.

Bielza, P. 2008. Insecticide resistance management strategies against the western flower thrips, Frankliniella occidentalis. Pest Management Science 64, 1131-1138.

Biondi, A., Zappalà, L., Di Mauro, A., Tropea Garzia, G., Russo, A., Desneux, N., Siscaro, G., 2016. Can alternative host plant and prey affect phytophagy and biological control by the zoophytophagous mirid Nesidiocoris tenuis? BioControl 61, 79-90. 
Blaeser, P., Sengonca, C., Zegula, T., 2004. The potential use of different predatory bug species in the biological control of Frankliniella occidentalis (Pergande) (Thysanoptera: Thripsidae). Journal of Pest Science 77, 211-219.

Bloemhard, C., Ramakers, P., 2008. Strategies for aphid control in organically grown sweet pepper in the Netherlands. IOBC/WPRS Bulletin 32, 25-28.

Blom, J.V.D., Ramos, M., Ravensberg, W., 1997. Biological pest control in sweet pepper in Spain: introduction rates of predators of Frankliniella occidentalis. IOBC/WPRS Bulletin 20, 196-202.

Blom, J.V.D., Lafuente, M., Galeano, M., Pérez, E., Urbaneja, A., Pass, R.V.D., Ravensberg, W., 2003. The efficacy of Verticillium lecanii against whitefly in sweet pepper and tomato in Spain. "Insect Pathogens and Insect Parasitic Nematodes". IOBC/WPRS Bulletin 28, 77-80.

Blom, J.V.D., 2008. Pimiento bajo abrigo. In: Jaques, J.A., Urbaneja, A., (Eds.), Control biológico de plagas agrícolas. Phytoma España, Valencia, Spain, pp. 399-409.

Blom, J.V.D., Robledo, A., Torres, S., Sánchez, J.A., 2009. Consequences of the wide scale implementation of biological control in greenhouse horticulture in Almeria, Spain. IOBC/WPRS Bulletin 49, 9-13.

Blom, J.V.D., 2010. Applied entomology in Spanish greenhouse horticulture. Proceedings of the Netherlands Entomological Society Meeting 21, 9-17.

Blom, J.V.D., 2017. Control Biológico en cultivos hortícolas en Almería: balance después de 10 años Boletin de la SEEA 2, 34-38.

Blümel, S., 2004. Biological control of aphids on vegetable crops. In: Heinz, K.M., Van Driesche, R.G., Parrella, M.P., (Eds.), Biocontrol in protected culture. Ball Publishing, Batavia, Illinois, pp. 297-312. 
Boachon, B., Gamir, J., Pastor, V., Erb, M., Dean, J.V., Flors, V., MauchMani, B., 2014. Role of two UDP-Glycosyltransferases from the L group of Arabidopsis in resistance against Pseudomonas syringae. European Journal of Plant Pathology 139, 707-720.

Bodenhausen, N., Reymond, P., 2007. Signaling pathways controlling induced resistance to insect herbivores in Arabidopsis. Molecular Plant-Microbe Interactions 20, 1406-1420.

Bonato, O., Couton, L., Fargues, J. 2006. Feeding Preference of Macrolophus caliginosus (Heteroptera: Miridae) on Bemisia tabaci and Trialeurodes vaporariorum (Homoptera: Aleyrodidae). Journal of Economic Entomology 99, 1143-1151.

Bonato, O., Lurette, A., Vidal, C., Fargues, J., 2007. Modelling temperaturedependent bionomics of Bemisia tabaci (Q-biotype). Physiological Entomology 32, 50-55.

Bonte, M., De Clercq, P., 2008. Developmental and reproductive fitness of Orius laevigatus (Hemiptera: Anthocoridae) reared on factitious and artificial diets. Journal of Economic Entomology 101, 1127-1133.

Bosco, L., Giacometto, E., Tavella, L., 2008. Colonization and predation of thrips (Thysanoptera: Thripidae) by Orius spp. (Heteroptera: Anthocoridae) in sweet pepper greenhouses in Northwest Italy. Biological Control 44, 331-340.

Bouagga, S., Urbaneja, A., Rambla, J.L., Flors, V., Granell, A., Jaques, J.A., Pérez-Hedo, M., 2017. Zoophytophagous mirids provide pest control by inducing direct defences, antixenosis and attraction to parasitoids in sweet pepper plants. Pest Management Science DOI: 10.1002/ ps.4838. 
Bouagga, S., Urbaneja, A., Rambla, J.L., Granell, A., Pérez-Hedo, M., 2018.

Orius laevigatus strengthens its role as a biological control agent by inducing plant defences. Journal of Pest Science 91, 55-64.

Brodsgaard, H.F., Albajes, R., 1999. Insect and Mite Pests. In: Albajes, R., Gullino, M.L., van Lenteren, J.C., Elad, Y., (Eds.), Integrated pest and disease management in greenhouse crops. Kluwer Academic Publishers, Netherland, pp. 48-60.

Bruce, T.J., Pickett, J.A., 2007. Plant defence signalling induced by biotic attacks. Current Opinion in Plant Biology 10, 387-392.

CABI., 2017. Plantwise knowledge bank. Tomato bug (Nesidicoris tenuis). http:// www.plantwise.org/KnowledgeBank/Datasheet.aspx?dsid=16251. Accessed 22 July 2017.

Calvo, F.J., Urbaneja, A., 2003. Nesidiocoris tenuis (Het: Miridae) en tomate: Amigo o Enemigo? Almería en Verde 4, 21-23.

Calvo, F.J., Urbaneja, A., 2004a. Nesidiocoris tenuis, un aliado para el control biológico de la mosca blanca. Horticultura Internacional 44, 20-25.

Calvo, F.J., Urbaneja, A., 2004b. Empleo de plantas reservorio de parasitoides en el control de pulgones. Phytoma España 155, 26-34.

Calvo, F.J., Bleda, J., Bolckmans, K., 2008. Controlling the tobacco Whitefly Bemisia tabaci (Genn.) (Hom.: Aleyrodidae) in horticultural crops with the predatory mite Amblyseius swirskii (Athias-Henriot). Journal of Insect Science 8, 11-12.

Calvo, F.J., Bolckmans, K., Belda, J.E., 2009a. Development of a biological control-based integrated pest management method for Bemisia tabaci for protected sweet pepper crops. Entomologia Experimentalis et Applicata 133, 9-18. 
Calvo, F.J., Bolckmans, K., Stansly, P.A., Urbaneja, A., 2009b. Predation by Nesidiocoris tenuis on Bemisia tabaci and injury to tomato. BioControl 54, 237-246.

Calvo, F.J., Bolckmans, K., Belda, J.E., 2011. Control of Bemisia tabaci and Frankliniella occidentalis in cucumber by Amblyseius swirskii. BioControl 56, 185-192.

Calvo, F.J., Bolckmans, K., Beldaa, J.E., 2012a. Biological control-based IPM in sweet pepper greenhouses using Amblyseius swirskii (Acari: Phytoseiidae). Biocontrol Science and Technology 22, 1398-1416.

Calvo, F.J., Bolckmans, K., Belda, J.E., 2012b. Release rate for a preplant application of Nesidiocoris tenuis for Bemisia tabaci control in tomato. BioControl 57, 809-817.

Calvo, F.J., Lorente, M.J., Stansly, P.A., Belda, J.E., 2012c. Preplant release of Nesidiocoris tenuis and supplementary tactics for control of Tuta absoluta and Bemisia tabaci in greenhouse tomato. Entomologia Experimentalis et Applicata 143, 111-119.

Calvo, F.J., Knapp, M., van Houten, Y.M., Hoogerbrugge, H., Belda, J.E., 2015. Amblyseius swirskii: What made this predatory mite such a successful biocontrol agent? Experimental and Applied Acarology 65, 419-433.

Cano, M., Vila, E., Janssen, D., Bretones, G., Salvador, E., Lara, L., Tellez, M.M., 2009. Selection of refuges for Nesidiocoris tenuis (Het.: Miridae) and Orius laevigatus (Het.: Anthocoridae): virus reservoir risk assessment. IOBC/WPRS Bulletin 49, 281-286.

Castañé, C., Alomar, O., Riudavets, J., 1996. Management of western flower thrips on cucumber with Dicyphus tamaninii (Heteroptera: Miridae). Biological Control 7, 114-120. 
Castañé, C., Alomar, O., Riudavets, J., 2003. Potential risk of damage to zucchinis caused by mirid bugs. IOBC/WPRS Bulletin 26, 135-138.

Castañé, C., Alomar, O., Goula, M., Gabarra, R., 2004. Colonization of tomato greenhouses by the predatory mirid bugs Macrolophus caliginosus and Dicyphus tamaninii. Biological Control 30, 591-597

Castañé, C., Zapata, R., 2005. Rearing the predatory bug Macrolophus caliginosus on a meat-based diet. Biological Control 34, 66-72.

Castañé, C., Quero, R., Riudavets, J., 2006. The brine shrimp Artemia sp as alternative prey for rearing the predatory bug Macrolophus caliginosus. Biological Control 38, 405-412.

Castañé, C., Arnó, J., Gabarra, R., Alómar, O., 2011. Plant damage to vegetable crops by zoophytophagous mirid predators. BioControl 59, 22-29.

Catalán, J., Verdú, M.J., 2005. Evaluación de dos parasitoides de huevos de Nezara viridula. Boletín de Sanidad Vegetal Plagas 31, 187-197.

Chambers, R., Long, S., Helyer, N.L., 1993. Effectiveness of Orius laevigatus (Hem, Anthocoridae) for the control of Frankliniella occidentalis on cucumber and pepper in the UK. Biocontrol Science \& Technology 3, 295-307.

Christensen, R.K., Enkegaard, A., Brodsgaard, H.F., 2002. Intraspecific interactions among the predators Orius majusculus and Aphidoletes aphidimyza. IOBC/WPRS Bulletin 25, 57-60.

Cock, M.J.W., van Lenteren, J.C., Brodeur, J., Barratt, B.I.P, Bigler, F., Bolckmans, K., Consoli, F.L., Haas, F., Mason, P.G., Parra, J.R.P., 2010. Do new access and benefit sharing procedures under the convention on biological diversity threaten the future of biological control? BioControl 55,199-218. 
Cocuzza, G.E., De Clercq, P., Van de Veire, M., De Cock, A., Degheele, D., Vacante, V., 1997. Reproduction of Orius laevigatus and Orius albidipennis on pollen and Ephestia kuehniella eggs. Entomologia Experimentalis et Applicata 82, 101-104.

Colazza, S., Peri, E., Salerno, G., Conti, E., 2010. Host searching by egg parasitoids: exploitation of host chemical cues. In: Parra, J.R.P., Consoli, F.L., Zucchi, R.A., (Eds.), Egg parasitoids in agroecosystems with emphasis on Trichogramma. Springer, New York, pp. 97-147.

Coll, M., Ridgway, R.L., 1995. Functional and Numerical Responses of Orius insidiosus (Heteroptera: Anthocoridae) to its prey in different vegetable crops. Annals of the Entomological Society of America 88, 732-738.

Coll, M., 1996. Feeding and ovipositing on plants by an omnivorous insect predator. Oecologia 105, 214-220.

Coll, M., Guershon, M., 2002. Omnivory in terrestrial arthropods: Mixing plant and prey diets. Annual Review of Entomology 47, 267-297.

Conti, E., Colazza, S., 2012. Chemical ecology of egg parasitoids associated with true bugs. Psyche 2012, 1-11.

Coss-Romero, M., Pena, J.E., 1998. Relationship of broad mite (Acari: Tarsonemidae) to host phenology and injury levels in Capsicum annuum. Florida Entomology 81, 515-526.

De Backer, L., Megido, R.C., Fauconnier, M.L., Brostaux, Y., Francis, F., Verheggen, F., 2015. Tuta absoluta-induced plant volatiles: attractiveness towards the generalist predator Macrolophus pygmaeus. Arthropod-Plant Interactions 9, 465-476.

De Barro, P.J., Liu, S.S., Boykin, L.M., Dinsdale, A.B., 2011. Bemisia tabaci: A statement of species status. Annual Review of Entomology 56, 1-19. 
De Moraes, C.M., Mescher, M.C., Tumlinson, J.H., 2001. Caterpillarinduced nocturnal plant volatiles repel conspecific females. Nature 410, 577-580.

De Puysseleyr, V., Hofte, M., De Clercq, P., 2011. Ovipositing Orius laevigatus increase tomato resistance against Frankliniella occidentalis feeding by inducing the wound response. Arthropod-Plant Interactions 5, 71-80.

De Vos, M., Van Oosten, V.R., Van Poecke, R.M.P., Van Pelt, J.A., Pozo, M.J., Mueller, M.J., Buchala, A.J., Métraux, J.P., Van Loon, L.C., Dicke, M., Pieterse, C.M.J., 2005. Signal signature and transcriptome changes of Arabidopsis during pathogen and insect attack. Molecular Plant-Microbe Interactions 18, 923-937.

Dewhirst, S.Y., Birkett, M.A., Loza-Reyes, E., Martin, J.L., Pye, B.J., Smart, L.E., Hardie, J., Pickett, J.A., 2012. Activation of defence in sweet pepper, Capsicum annum, by cis-jasmone, and its impact on aphid and aphid parasitoid behaviour. Pest Management Science 68, 1419-1429.

Dicke, M., Sabelis, M.W., 1988. How plants obtain predatory mites as bodyguards. Netherlands Journal of Zoology 38, 148-165.

Dicke, M., Sabelis, M.W., Takabayashi, J., 1990. Do plants cry for help? Evidence related to a tritrophic system of predatory mites, spider mites and their host plants. Insects-Plants 89, 127-134.

Dicke, M., van Loon, J.J.A., 2000. Multitrophic effects of herbivore-induced plant volatiles in an evolutionary context. Entomologia Experimentalis et Applicata 97, 237-249.

Dicke, M., van Poecke, R.M.P., 2002. Signaling in plant-insect interactions: signal transduction in direct and indirect plant defence. In: Scheel, D., Wasternack, C., (Eds.), Plant signal transduction. Oxford University Press, pp. 289-316. 
Dicke, M., van Loon, J.J.A., Soler, R., 2009. Chemical complexity of volatiles from plants induced by multiple attack. Nature Chemical Biology 5, 317-324.

Dicke, M., Baldwin, I.T., 2010. The evolutionary context for herbivoreinduced plant volatiles: beyond the 'cry for help'. Trends in Plant Science 15, 167-175.

Dicke, M., van Loon, J.J.A., 2014. Chemical ecology of phytohormones: how plants integrate responses to complex and dynamic environments. Journal of Chemical Ecology 40, 653-656.

Dik, A.J., Ceglarska, E., Ilovai, Z., 1999. Sweet peppers. In: Albajes, R., Gullino, M.L., van Lenteren, J.C., Elad, Y., (Eds.), Integrated pest and disease management in greenhouse crops. Springer Netherlands, Dordrecht, pp. 473-485.

Dissevelt, M., Altena, K., Ravensberg, W.J., 1995. Comparison of different Orius species for control of Frankliniella occidentalis in glasshouse vegetable crops in the Netherlands. Medical Faculty of landbouww University Gent 60, 839-845.

Drukker, B., Scutareanu, P., Sabelis, M.W., 1995. Do anthocorid predators respond to synomones from Psylla-infested pear trees under field conditions? Entomologia Experimentalis et Applicata 77, 193-203.

Duarte, L., Pacheco, R., Quiñones, M., Martínez, M.Á., Paes Bueno, V.H., 2014. Nesidiocoris tenuis Reuter (Hemiptera: Miridae) and Cycloneda sanguinea Limbifer Casey (Coleoptera: Coccinellidae): behaviour and predatory activity on Myzus persicae Sulzer (Hemiptera: Aphididae). Revista de Protección Vegetal 29, 99-105. 
Dudareva, N., Negre, F., Nagegowda, D.A., Orlova, I., 2006. Plant volatiles: Recent advances and future perspectives. Critical Reviews in Plant Sciences 25, 417-440.

Durán Prieto, J., Castañé, C., Calvet, C., Camprubi, A., Battaglia, D., Trotta, V., Fant, P., 2016. Tomato belowground-aboveground interactions: Rhizophagus irregularis affects foraging behavior and life history traits of the predator Macrolophus pygmaeus (Hemiptera: Miridae). Arthropod-Plant Interactions 11, 15-22.

Elbert, A., Nauen, R., 2000. Resistance of Bemisia tabaci (Homoptera: Aleyrodidae) to insecticides in southern Spain with special reference to neonicotinoids. Pest Management Science 56, 60-64.

El-Dessouki, S.A., El Kifl, A.H., Helal, A., 1976. Life cycle, host plants and symptoms of damage of the tomato bug, Nesidiocoris tenuis Reut. (Hemiptera: Miridae), in Egypt. Journal of Plant Diseases and Protection 84, 204-220.

Erb, M., Robert, C.A.M., Hibbard, B.E., Turlings, T.C.J., 2011. Sequence of arrival determines plant-mediated interactions between herbivores. Journal of Ecology 99, 7-15.

Erb, M., Meldau, S., Howe, G.A., 2012. Role of phytohormones in insect specific plant reactions. Trends in Plant Science 17, 250-259.

Evans, E.W., Dixon, A.F.G., 1986. Cues for oviposition by Ladybird beetles (Coccinellidae): response to aphids. Journal of Animal Ecology 55, 1027-1034.

Evans, E.W., Stevenson, A., Richards, D., 1999. Essential versus alternative foods of insect predators: benefits of a mixed diet. Oecologia 121, 107-112. 
FAOSTAT., 2016. Food and Agriculture Organization of the United Nations Statistics. http://faostat.fao.org/site/339/default.aspx. Accessed 8 July 2017.

Fantinou, A.A., Perdikis, D.C., Maselou, D.A., Lambropoulos, P.D., 2008. Prey killing without consumption: Does Macrolophus pygmaeus show adaptive foraging behaviour? Biological Control 47, 187-193.

Fantinou, A.A., Perdikis, D.C., Lambropoulos, P.D., Maselou, D.A. 2009. Preference and consumption of Macrolophus pygmaeus preying on mixed instar assemblages of Myzus persicae. Biological Control 51, 76-80.

Fauvel, G., Malausa, J., Kaspar, B., 1987. Etude en laboratoire des principales characteristiques biologiques de Macrolophus caliginosus (Heteroptera: Miridae). Entomophaga 32, 529-543.

Fernández-Zamudio, M.A., Pérez,A., Caballero, P., 2006. Análisis económico de la tecnología de los invernaderos mediterráneos: Aplicación en la producción del pimiento. Información Técnica Económica Agraria $102,260-277$.

Ferreira, J.A.M., Eshuis, B., Janssen, A., Sabelis, M.W., 2008. Domatia reduce larval cannibalism in predatory mites. Ecological Entomology 33, 374-379.

Flors, V., Ton, J., van Doorn, R., Jakab, G., Garcia-Agustin, P., MauchMani, B., 2008. Interplay between JA, SA and ABA signaling during basal and induced resistance against Pseudomonas syringae and Alternaria brassicicola. Plant Journal 54, 81-92.

Forcat, S., Bennett, M.H., Mansfield, J.W., Grant, M.R., 2008. A rapid and robust for simultaneously measuring changes in the phytohormones ABA, JA and SA following biotic and abiotic stress. Plant methods 4, 16. 
Fortes, I.M., Moriones, E., Navas-Castillo, J., 2012. Tomato chlorosis virus in pepper: prevalence in commercial crops in southeastern Spain and symptomatology under experimental conditions. Plant Pathology 61, 994-1001.

Franco, K., Jauset, A., Castañé, C., 2011. Monogamy and polygamy in two species of mirid bugs: A functional-based approach. Journal of Insect Physiology 57, 307-315.

Frescata, C., Mexia, A., 1996. Biological control of thrips (Thysanoptera) by Orius laevigatus (Heteroptera: Anthocoridae) in organically-grown strawberries. Biological Agriculture \& Horticulture 13, 141-148.

Fritsche, M.E., Tamò, M., 2000. Influence of thrips prey species on the life-history and behaviour of Orius albidipennis. Entomologia Experimentalis et Applicata 96, 111-118.

Fürstenberg-Hägg, J., Zagrobelny, M., Bak, S., 2013. Plant defense against insect herbivores. International Journal of Molecular Sciences 14, 10242-10297.

Gabarra, R., Alómar, Ò., Castañé, C., Goula, M., Albajes, R., 2004. Movement of greenhouse whitefly and its predators between in-and outside of Mediterranean greenhouses. Agriculture, Ecosystems \& Environment 102, 341-348.

Gabarra, R., Arnó, J., Riudavets, J., 2008. Tomate. In: Jaques, J.A., Urbaneja, A., (Eds.), Control biológico de plagas agrícolas. Phytoma-España, Valencia, Spain, pp. 410-422.

Gadino, A.N., Walton, V.M., Lee, J.C., 2012. Evaluation of methyl salicylate lures on populations of Typhlodromus pyri (Acari: Phytoseiidae) and other natural enemies in western Oregon vineyards. Biological Control 63, 48-55. 
Gerling, D., Alomar, O., Arnó, J., 2001. Biological control of Bemisia tabaci using predators and parasitoids. Crop Protection 20, 779-799.

Gill, R., Gupta, A., Taggar, G., Taggar, M., 2010. Review article: Role of oxidative enzymes in plant defenses against insect herbivory. Acta Phytopathologica et Entomologica Hungarica 45, 277-290.

Gillespie, D.R., McGregor, R.R., 2000. The functions of plant feeding in the omnivorous predator Dicyphus hesperus: water places limits on predation. Ecological Entomology 25, 380-386.

Glazebrook, J., 2005. Contrasting mechanisms of defense gainst biotrophic and necrotrophic pathogens. Annual Review of Phytopathology 43, 205-227.

Godinho, D.P., Janssen, A., Dias, T., Cruz, C., Magalhães, S., 2016. Downregulation of plant defence in a resident spider mite species and its effect upon con- and heterospecifics. Oecologia 180, 161-167.

Goodrich-Tanrikulu, M., Mahoney, N.E., Rodriguez, S.B., 1995. The plant growth regulator methyl jasmonate inhibits aflatoxin production by Aspergillus flavus. Microbiology 141, 2831-2837.

Gosset, V., Harmel, N., Göbel, C., Francis, F., Haubruge, E., Wathelet, J.P., Fauconnier, M.L., 2009. Attacks by a piercing-sucking insect (Myzus persicae Sulzer) or a chewing insect (Leptinotarsa decemlineata Say) on potato plants (Solanum tuberosum L.) induce differential changes in volatile compound release and oxylipin synthesis Journal of Experimental Botany 60, 1231-1240.

Goula, M., Alómar, O., 1994. Míridos (Heteroptera: Miridae) de interés en el control integrado de plagas en el tomate. Guía para su identificación Boletín de Sanidad Vegetal. Plagas 20, 131-143. 
Griffiths, D.A., 1999. Biological control of mites. In: Albajes, R., Gullino, M.L., van Lenteren, J.C., Elad, Y., (Eds.), Integrated pest and disease management in greenhouse crops. Kluwer Academic Publishers, Netherland, pp. 217-234.

Groux, R., Hilfiker, O., Gouhier-Darimont, C., Peñaflor, M.F.G.V., Erb, M., Reymond, P., 2014. Role of methyl salicylate on oviposition deterrence in Arabidopsis thaliana. Journal of Chemical Ecology 40, 754-759.

Halitschke, R., Hamilton, J.G., Kessler, A., 2011. Herbivore-specific elicitation of photosynthesis by mirid bug salivary secretions in the wild tobacco Nicotiana attenuata. New Phytologist 191, 528-535.

Hamdan, A.J.S., Abu-Awad, I.T., 2007. Effect of host plants on predator prey relationship between predatory bug, Orius laevigatus (Fiber) [Hemiptera: Anthocoridae] and tobacco whitefly, Bemisia tabaci (Gennadius) [Homoptera: Aleyrodidae]. An-Najah University Journal for Research 21, 85-99.

Hamdan, A.J.S., Abu-Awad, I.T., 2008. Biological aspects of the predatory bug Orius laevigatus (Fiber) [Hemiptera: Anthocoridae] when fed on the tobacco whitefly Bemisia tabaci (Gennadius) [Homoptera: Aleyrodidae] spread on tomato and eggplant. Dirasat: Agricultural Sciences 35, 81-91.

Hanley, M.E., Lamont, B.B., Fairbanks, M.M., Rafferty, C.M., 2007. Plant structural traits and their role in anti-herbivore defence. Perspectives in Plant Ecology, Evolution and Systematics 8, 157-178.

Hansen, D.L., Brodsgaard,H.F., Enkegaard, A., 1999. Life table characteristics of Macrolophus caliginosus preying upon Tetranychus urticae. Entomologia Experimentalis et Applicata 93, 269-275. 
Hare, J.D., 2011. Ecological role of volatiles produced by plants in response to damage by herbivorous insects. Annual Review of Entomology 65, 161-180.

Hassanpour, M., Bagheri, M., Golizadeh, A., Farrokhi, S., 2016. Functional response of Nesidiocoris tenuis (Hemiptera: Miridae) to Trialeurodes vaporariorum (Hemiptera: Aleyrodidae): effect of different host plants. Biocontrol Science and Technology 26, 1489-1503.

He, J., Chen, F., Chen, S., Lv, G., Deng, Y., Fang, W., Liu, Z., Guan, Z., He, C., 2011. Chrysanthemum leaf epidermal surface morphology and antioxidant and defense enzyme activity in response to aphid infestation. Journal of Plant Physiology 168, 687-693.

Heil, M., Ton, J., 2008. Long-distance signaling in plant defence. Trends in Plant Science 13, 264-272.

Heil, M., Karban, R., 2010. Explaining evolution of plant communication by airborne signals. Trends in Ecology \& Evolution 25, 137-144.

Heil, M., 2014. Herbivore-induced plant volatiles: targets, perception and unanswered questions. New Phytologist 204, 297-306.

Heimpel, G.E., Mills, N.J., 2017. Biological Control: Ecology and Applications. Cambridge University Press, United kingdom.

Heiser, C.B., 1976. Peppers Capsicum (Solanaceae). In: Simmonds, N.W., (Ed.), The evolution of crops plants. Longman Press, London, pp. 265-268.

Hemptinne, J.L., Dixon, A.F.G., Coffin, J., 1992. Attack strategy of ladybird beetles (Coccinellidae): factors shaping their numerical response. Oecologia 90, 238-245. 
Hernandez, L.M., Stonedahl, GM., 1999. A review of the economically important species of the genus Orius (Heteroptera: Anthocoridae) in East Africa. Journal of Natural History 33, 543-568.

Hilker, M., Meiners, T., 2010. How do plants "notice" attack by herbivorous arthropods? Biological Reviews 85, 267-280.

Holopainen, J.K., Blande, J.D., 2012. Molecular plant volatile communication. In: López-Larrea, C., (Ed.), Sensing in Nature. Springer USA, New York, pp. 17-31.

Holt, R.D. 1977. Predation, apparent competition and the structure of prey communities. Theoretical Population Biology 12, 197-229.

Holt, R.D., Lawton, J.H., 1994. The ecological consequences of shared natural enemies. Annual Review of Ecology, Evolution, and Systematics 25, 495-520.

Holt, R.D., Polis, G.A., 1997. A theoretical framework for intraguild predation. The American Naturalist 149, 745-764.

Holt, R.D., Huxel, G.R., 2007. Alternative prey and the dynamics of intraguild predation: Theoretical perspectives. Ecology 88, 2706-2712.

Hortoinfo., 2017. Informe pimiento http://www.hortoinfo.es/index.php/ informes/cultivos/6011-inf-pim-2017 (Accessed 10 September 2017).

Hosseini, M., Ashouri, A., Enkegaard, A., Weisser, W.W., Goldansaz, S.H., Mahalati, M.N., Moayeri, H.R.S., 2010. Plant quality effects on intraguild predation between Orius laevigatus and Aphidoletes aphidimyza. Entomologia Experimentalis et Applicata 135, 208-216.

Howe, G.A., Jander, G., 2008. Plant immunity to insect's herbivores. Annual Review of Plant Biology 59, 41-66. 
Huang, N.X., Enkegaard, A., Osborne, L.S., Ramakers, P.M.J., Messelink, G.J., Pijnakker, J., Murphy, G., 2011. The banker plant method in biological control. Critical Reviews in Plant Sciences 30, 259-278.

Hughes, G.E., Bale, J.S., Sterk, G., 2009. Thermal biology and establishment potential in temperate climates of the predatory mirid Nesidiocoris tenuis. BioControl 54, 785-795.

Hughes, G.E., Alford, L., Sterk, G., Bale, J.S., 2010. Thermal activity thresholds of the predatory mirid Nesidiocoris tenuis: implications for its efficacy as a biological control agent. BioControl 55, 493-501.

Huot, B., Yao, J., Montgomery, B.L., He, S.Y., 2014. Growth-defense tradeoffs in plants: A balancing act to optimize fitness. Molecular Plant 7, 1267-1287.

Iason, G.R., Dicke, M., Hartley, S.E., 2012. The ecology of plant secondary metabolites from genes to global processes. Cambridge University Press United kingdom.

Ingegno, B.L., Pansa, M.G., Tavella, L., 2009. Tomato colonization by predatory bug (Heteroptera: Miridae) in agroecosystems of NW Italy. IOBC/WPRS Bulletin 49, 287-291.

Ingegno, B.L., Pansa, M.G., Tavella, L., 2011. Plant preference in the zoophytophagous generalist predator Macrolophus pygmaeus (Heteroptera: Miridae). Biological Control 58, 174-181.

James, D.G., Price, T.S., 2004. Field-testing of methyl salicylate for recruitment and retention of beneficial insects in grapes and hops. Journal of Chemical Ecology 30, 1613-1628.

Janssen, A., Pallini, A., Venzon, M., Sabelis, M.W., 1998. Behaviour and indirect interactions in food webs of plant-inhabiting arthropods. Experimental and Applied Acarology 22, 497-521. 
Janssen, A., Montserrat, M., HilleRisLambers, R., de Roos, A.M., Pallini, A., Sabelis, M.W., 2006. Intraguild predation usually does not disrupt biological control. In: Brodeur, J., Boivin, G., (Eds.), Trophic and guild interactions in biological control. Springer, Netherlands, Dordrecht, pp. 21-44.

Jonathan, G.L., Fergen, J., 2006. The oviposition behavior of the predator Orius insidiosus: acceptability and preference for different plants. BioControl 51, 217-227.

Jones, D.R., 2003. Plant viruses transmitted by whiteflies. European Journal of Plant Pathology 109, 195-219.

Jung, H.W., Tschaplinski, T.J., Wang, L., Glazebrook, J., Greenberg, J.T., 2009. Priming in systemic plant immunity. Science 324, 89-91.

Kant, M.R., Sabelis, M.W., Haring, M.A., Schuurink, R.C., 2008. Intraspecific variation in a generalist herbivore accounts for differential induction and impact of host plant defences. Proceedings of the Royal Society: Biological Sciences 275, 443-452.

Kant, M.R., Jonckheere, W., Knegt, B., Lemos, F., Liu, J., Schimmel, B.C.J., Villarroel, C.A., Ataide, L.M.S., Dermauw, W., Glas, J.J., Egas, M., Janssen, A., Van Leeuwen, T., Schuurink, R.C., Sabelis, M.W., Alba, J.M., 2015. Mechanisms and ecological consequences of plant defence induction and suppression in herbivore communities. Annals of Botany 115, 1015-1051.

Karban, R., 2011. The ecology and evaluation of induced resistance against herbivores. Functional Ecology 25, 339-347.

Karban, R., Baldwin, I.T., 1997. Induced Responses to Herbivory. University of Chicago Press, Chicago, United state. 
Karban, R., Shiojiri, K., Huntzinger, M., McCall, A.C., 2006. Damageinduced resistance in sagebrush: volatiles are key to intra- and interplant communication. Ecology Letters 87, 922-930.

Karban, R., Wetzel, W.C., Shiojiri, K., Ishizaki, S., Ramirez, S.R., Blande, J.D., 2014. Deciphering the language of plant communication: volatile chemotypes of sagebrush. New Phytologist 204, 380-385.

Kessler, A., Baldwin, I.T., 2001. Defensive function of herbivore-induced plant volatile emissions in nature. Science 291, 2141-2144.

Kessler, A., Baldwin, I.T., 2002. Plant responses to insect herbivory: the emerging molecular analysis. Annual Review of Plant Biology 53, 299-328.

Kessler, A., Baldwin, I.T., 2004. Herbivore-induced plant vaccination. Part I. The orchestration of plant defenses in nature and their fitness consequences in the wild tobacco Nicotiana attenuata. The Plant Journal 38, 639-649.

Kessler, A., 2017. Plant defences against herbivore attack. Els. John Wiley \& Sons, Ltd.

Kigathi, R.N., Unsicker, S.B., Reichelt, M., Kesselmeier, J., Gershenzon, J., Weisser, W.W., 2009. Emission of volatile organic compounds after herbivory from Trifolium pratense (L.) under laboratory and field conditions. Journal of Chemical Ecology 35, 1335-1348.

Komi, K., 2016. Biological control of pest insects in greenhouses use of natural enemy in Kochi Prefecture. Japanese Journal of Pesticide Science 41, 69-73.

Koschier, E.H., Hoffmann, D., Riefler, J., 2007. Influence of salicylaldehyde and methyl salicylate on post-landing behaviour of Frankliniella occidentalis Pergande. Journal of Applied Entomology 131, 362-367. 
Krishna, P., 2004. Plant responses to heat stress. In: Hirt, H., Shinozaki, K., (Eds.), Plant responses to abiotic stress. Springer Berlin Heidelberg, Berlin, Heidelberg, pp. 73-101.

Lacasa, A., Torres, J., Martínez, M.C, 1991. La implicación de Frankliniella occidentalis en la diseminación del virus del bronceado del tomate (TSWV) en los cultivos murcianos. Agrícola Vergel 112, 203-209.

Lacasa, A., Contreras, J. 1993. Comportamiento de Frankliniella occidentalis en la trasmisión del virus del bronceado del tomate: planteamientos para su control. Phytoma, Spain 50, 33-39.

Lattin, J.D., 1999. Bionomics of the Anthocoridae. Annual Review of Entomology 44, 207-231.

Lee, D.H., Nyrop, J.P., Sanderson, J.P., 2014. Non-consumptive effects of the predatory beetle Delphastus catalinae (Coleoptera: Coccinellidae) on habitat use patterns of adult whitefly Bemisia argentifolii (Hemiptera: Aleyrodidae). Applied Entomology and Zoology 49, 599-606.

Lenfant, C., Ridray, G., Schoen, L., 2000. Biopropagation of Macrolophus caliginosus Wagner for a quicker establishment in Southern tomato greenhouses. IOBC/WPRS Bulletin 23, 247-251.

Li, L., Li, C., Lee, G.I., Howe, G.A., 2002. Distinct roles for jasmonate synthesis and action in the systemic wound response of tomato. Proceedings of the National Academy of Sciences of the United States of America 99, 6416-6421.

Lins, J.C., van Loon, J.J.A., Bueno, V.H.P., Lucas-Barbosa, D., Dicke, M., van Lenteren, J.C., 2014. Response of the zoophytophagous predators Macrolophus pygmaeus and Nesidiocoris tenuis to volatiles of uninfested plants and to plants infested by prey or conspecifics. BioControl 59, 707-718. 
Liu, L., Sonbol, F.M., Huot, B., Gu, Y., Withers, J., Mwimba, M., Yao, J., He, S.Y., Dong, X., 2016. Salicylic acid receptors activate jasmonic acid signaling through a non-canonical pathway to promote effectortriggered immunity. Nature Communications 7, 13099.

Lof, M.E., Etienne, R.S., Powell, J., de Gee, M., Hemerik, L., 2008. The effect of chemical information on the spatial distribution of fruit flies: I model results. Bulletin of Mathematical Biology 70, 1827-1849.

Lucas, É., Coderre, D., Brodeur, J., 1998. Intraguild Predation among aphid predators: characterization and influence of extraguild prey density. Ecology 79, 1084-1092.

Lucas, É., Alómar, O., 2001. Macrolophus caliginosus Wagner as an Intraguild Prey for the Zoophytophagous Dicyphus tamaninii Wagner (Heteroptera: Miridae). Biological Control 20, 147-152.

Lundgren, J.G., Fergen, J.K., Riedell, W.E., 2008. The influence of plant anatomy on oviposition and reproductive success of the omnivorous bug Orius insidiosus. Animal Behaviour 75, 1495-1502.

Lundgren, J.G., Hesler, L.S., Tilmon, K., Dashiell, K., Scott, R., 2009. Direct effects of soybean varietal selection and Aphis glycines-resistant soybeans on natural enemies. Arthropod-Plant Interactions 3, 9-16.

Lykouressis, D.P., Perdikis, D.C., Tsagarakis, A., 2000. Polyphagous mirids in Greece: Host plants and abundance in traps placed in some crops. Bollotino Laboratorio Entomologia Agraria Filippo Silvestri 56, 57-68. Lykouressis,D.P.,Perdikis,D.C.,Michalaki,M.,2001.Nymphaldevelopment and survival of Macrolophus pygmaeus Rambur (Hemiptera: Miridae) on two eggplant varieties as affected by temperature and presence/ absence of prey. Biological Control 20, 222-227. 
Lykouressis, D.P., Giatropoulos, A., Perdikis, D., Favas, C., 2008. Assessing the suitability of noncultivated plants and associated insect prey as food sources for the omnivorous predator Macrolophus pygmaeus (Hemiptera: Miridae). Biological Control 44, 142-148.

Lykouressis, D.P., Perdikis, D.C., Charalambous, P., 2014. Plant food effects on prey consumption by the omnivorous predator Macrolophus pygmaeus. Phytoparasitica 42, 303-309.

Maekawa, T., Kufer, T.A., Schulze-Lefert, P., 2011. NLR functions in plant and animal immune systems: So far and yet so close. Nature Immunology 12, 818-826.

Mallinger, R.E., Hogg, D.B., Gratton, C., 2011. Methyl salicylate attracts natural enemies and reduces populations of soybean aphids (Hemiptera: Aphididae) in soybean agroecosystems. Journal of Economic Entomology 104, 115-124.

Malausa, J.C., Trottin-Caudal, Y., 1996. Advances in the strategy of use of the predaceous bug Macrolophus caliginosus (Heteroptera: Miridae) in glasshouse crops. In: Alómar, O., Wiedenmann, R., (.Ed), Zoophytophagous Heteroptera: Implications for Life History and IPM. Thomas Say Special Publications in Entomology, Entomological Society of America, pp. 178-189

Malo, S., Arnó, J., Gabarra, R., 2012. Intraguild interactions between the predator Macrolophus pygmaeus and the parasitoid Eretmocerus mundus, natural enemies of Bemisia tabaci. Biocontrol Science and Technology 22, 1059-1073.

Mäntylä, E., Alessio, G.A., Blande, J.D., Heijari, J., Holopainen, J.K., Laaksonen, T., Piirtola, P., Klemola, T., 2008. From plants to birds: higher avian predation rates in trees responding to insect herbivory. PLoSONE 3, e2832. 
MARM., 2017. Ministerio de Agricultura, Alimentación y Medio Ambiente. Anuario de estadística. http://www.mapama.gob.es/es/estadistica/ temas/estadisticasagrarias/agricultura/avances-superficiesproducciones-agricolas/cuaderno_enero2016_tcm7-413905.pdf. Accessed 8 July 2017.

Martinez-Cascales, J.I., Cenis, J.L., Cassis, G., Sánchez, J.A., 2006. Species identity of Macrolophus melanotoma (Costa 1853) and Macrolophus pygmaeus (Rambur 1839) (Insecta: Heteroptera: Miridae) based on morphological and molecular data and bionomic implications. Insect \& Systematics Evolution 37, 385-404.

Maselou, D.A., Perdikis, D.C., Sabelis, M.W., Fantinou, A.A., 2014. Use of plant resources by an omnivorous predator and the consequences for effective predation. Biological Control 79, 92-100.

Matsui, K., 2006. Green leaf volatiles: Hydroperoxide lyase pathway of oxylipin metabolism. Current Opinion in Plant Biology 9, 274-280.

Mbabie, B., Omosun, G., Uti, A., Oyedemi, S., 2010. Chemical composition of Sesamum indicum L. (Sesame) grown in southeastern Nigeria and the physicochemical properties of the seed oil. Seed Science and Biotechnology 4, 69-72.

McCormick, C.A., Unsicker, S.B., Gershenzon, J., 2012. The specificity of herbivore-induced plant volatiles in attracting herbivore enemies. Trends in Plant Science 17, 303-310.

McCormick, C.A., Irmisch, S., Reiecke, A., Boeckler, A.G., Veit, D., Reichelt, M., Köllner, T.G., Hansson, B.S., Gershenzon, J., Unsicker, S.B., 2014. Herbivore-induced volatile emission in black poplar: regulation and role in attracting herbivore enemies. Plant, Cell \& Environment 37, 1909-1923. 
Messelink, G.J., van Steenpaal, S.E.F., Ramakers, P.M.J., 2006. Evaluation of phytoseiid predators for control of western flower thrips on greenhouse cucumber. BioControl 51, 753-768.

Messelink, G.J., van Maanen, R., van Steenpaal, S.E.F., Janssen, A., 2008. Biological control of thrips and whiteflies by a shared predator: two pests are better than one. Biological Control 44, 372-379.

Messelink, G.J., Van Maanen, R., Van Holstein-Saj, R., Sabelis, M.W., Janssen, A., 2010. Pest species diversity enhances control of spider mites and whiteflies by a generalist phytoseiid predator. BioControl 55, 387-398.

Messelink, G.J., Bloemhard, C.M.J., Kok, L., Janssen, A., 2011a. Generalist predatory bugs control aphids in sweet pepper. IOBC/WPRS Bulletin 68, 115-118.

Messelink, G.J., Bloemhard, C.M.J., Cortes, J.A., Sabelis, M.W., Janssen, A., 2011b. Hyperpredation by generalist predatory mites disrupts biological control of aphids by the aphidophagous gall midge Aphidoletes aphidimyza. Biological Control 57, 246-252.

Messelink, G.J., Sabelis, M.W., Janssen, A., 2012. Generalist predators, food web complexities and biological pest control in greenhouse crops. In: Larramendy, M.L., Soloneski, S., (Eds.), Integrated pest management and pest control-current and future tactics. INtech, pp. 192-214.

Messelink, G.J., Bloemhard, C.M.J., Sabelis, M.W., Janssen, A., 2013. Biological control of aphids in the presence of thrips and their enemies. BioControl 58, 45-55.

Messelink, G.J., Janssen, A., 2014. Increased control of thrips and aphids in greenhouses with two species of generalist predatory bugs involved in intraguild predation. Biological Control 79, 1-7. 
Messelink, G.J., Bloemhard, C.M.J., Hoogerbrugge, H., van Schelt, J., Ingegno, B.L., Tavella, L., 2015. Evaluation of mirid predatory bugs and release strategy for aphid control in sweet pepper. Journal of Applied Entomology 139, 333-341.

Millar, J.G., Rice, R.E., Wang, Q., 1997. Sex pheromone of the mirid bug Phytocoris relatious. Journal of Chemical Ecology 23, 1743-1754.

Millar, J.G., Rice, R.E., 1998. Sex pheromone of the plant bug Phytocoris californicus (Heteroptera: Miridae). Journal of Economic Entomology 91, 132-137.

Mithöfer, A., Boland, W., 2016. Do you speak chemistry? Small chemical compounds represent the evolutionary oldest form of communication between organisms. EMBP Reports 17, 626-629.

Moayeri, H.R.S., Ashouri, A., Brodsgaard, H.F., Enkegaard, A., 2006. Odour-mediated responses of a predatory mirid bug and its prey, the two-spotted spider mite. Experimental \& Applied Acarology 40, 27.

Moerkens, R., Berckmoes, E., Van Damme, V., Ortega-Parra, N., Hanssen, I., Wuytack, M., Wittemans, L., Casteels, H., Tirry, L., De Clercq, P., De Vis, R., 2016. High population densities of Macrolophus pygmaeus on tomato plants can cause economic fruit damage: interaction with Pepino mosaic virus? Pest Management Science 72, 1350-1358.

Moerkens, R., Berckmoes, E., Van Damme, V., Wittemans, L., Tirry, L., Casteels, H., De Clercq, P., De Vis, R., 2017. Inoculative release strategies of Macrolophus pygmaeus Rambur (Hemiptera: Miridae) in tomato crops: population dynamics and dispersal. Journal of Plant Diseases and Protection 124, 295-303. 
Mohd Rasdi, Z., Fauziah, I., WanMohamad, W.A.K., Syed Abdul Rahman, S.R., CheSalmah, M.R., Kamaruzaman, J., 2009. Biology of Macrolophus caliginosus (Heteroptera: Miridae) Predator of Trialeurodes vaporariorum (Homoptera: Aleyrodidae). International Journal of Biological Sciences 1, 63-70.

Mollá, Ó., Montón, H., Vanaclocha, P., Beitia, F., Urbaneja, A., 2009. Predation by the mirids Nesidiocoris tenuis and Macrolophus pygmaeus on the tomato borer Tuta absoluta. IOBC/WPRS Bulletin 49, 203-208.

Mollá, Ó., Gonzalez-Cabrera, J., Urbaneja, A., 2011. The combined use of Bacillus thuringiensis and Nesidiocoris tenuis against the tomato borer Tuta absoluta. BioControl 56, 883-891.

Montserrat, M., Albajes, R., Castañé, C., 2000. Functional response of four Heteropteran predators preying on greenhouse whitefly (Homoptera: Aleyrodidae) and western flower thrips (Thysanoptera: Thripidae). Environmental Entomology 29, 1075-1082.

Mumm, R., Dicke, M., 2010. Variation in natural plant products and the attraction of bodyguards involved in indirect plant defense. Canadian Journal of Zoology 88, 628-667.

Nakaishi, K., Fukui, Y., Arakawa, R., 2011. Reproduction of Nesidiocoris tenuis (Reuter) on Sesame. Japanese Journal of Applied Entomology and Zoology 55, 199-205.

Nakashima, Y., Hirose, Y., 2002. Sex differences in foraging behaviour and oviposition site preference in an insect predator, Orius sauteri. Entomologia Experimentalis et Applicata 106, 79-86.

Nannini, M., Atzori, F., Murgia, G., Pisci, R., Sanna, F., 2012. Use of predatory mirids for control of the tomato borer Tuta absoluta (Meyrick) in Sardinian greenhouse tomatoes. EPPO Bulletin 42, 255-259. 
Naranjo, S.E., 2001. Conservation and evaluation of natural enemies in IPM systems for Bemisia tabaci. Crop Protection 20, 835-852.

Naranjo, S.E., Castle, S.J., De Barro, P.J., Liu, S.S., 2010. Population dynamics, demography, dispersal and spread of Bemisia tabaci. In: Stansly, P.A., Naranjo, S.E., (Eds.), Bemisia: Bionomics and management of a global pest. Springer Netherlands, Dordrecht, pp. 185-226.

Naselli, M., Urbaneja, A., Siscaro, G., Jaques, J., Zappalà, L., Flores, V., Pérez-Hedo, M., 2016. Stage-related defense response induction in tomato plant by Nesidiocoris tenuis. International Journal of Molecular Sciences 17, 1210.

Naselli, M., Zappalà, L., Gugliuzzo, A., Tropea Garzia, G., Biondi, A., Rapisarda, C., Cincotta, F., Condurso, C., Verzera, A., Siscaro, G., 2017. Olfactory response of the zoophytophagous mirid Nesidiocoris tenuis to tomato and alternative host plants. Arthropod-Plant Interactions $11,121-131$.

Návarová, H., Bernsdorff, F., Döring, A.C., Zeier, J., 2012. Pipecolic Acid, an endogenous mediator of defense amplification and priming, is a critical regulator of inducible plant immunity. The Plant Cell 24, 5123-5141.

Nguyen, D.T., Vangansbeke, D., Lü, Xin., De Clercq, P., 2013. Development and reproduction of the predatory mite Amblyseius swirskii on artificial diets. BioControl 58, 369-377.

Nguyen, D.T., Vangansbeke, D., De Clercq, P., 2014. Artificial and factitious foods support the development and reproduction of the predatory mite Amblyseius swirskii. Experimental and Applied Acarology 62, 181-194. 
Ninkovic, V., Al Abassi, S., Pettersson, J., 2001. The influence of aphidinduced plant volatiles on ladybird beetle searching behavior. Biological Control 21, 191-195.

Ninkovic, V., Feng, Y., Olsson, U., Pettersson, J., 2013. Ladybird footprints induce aphid avoidance behavior. Biological Control 65, 63-71.

Nomikou, M., Janssen, A., Schraag, R., Sabelis, M.W., 2001. Phytoseiid predators as potential biological control agents for Bemisia tabaci. Experimental \& Applied Acarology 25, 271-291.

Nomikou, M., Janssen, A., Schraag, R., Sabelis, M.W., 2002. Phytoseiid predators suppress populations of Bemisia tabaci on cucumber plants with alternative food. Experimental \& Applied Acarology 27, 57-68.

Nomikou, M., Janssen, A., Sabelis, M.W., 2003. Herbivore host plant selection: whitefly learns to avoid host plants that harbour predators of her offspring. Oecologia 136, 484-488.

Nomikou, M., Janssen, A., Schraag, R., Sabelis, M.W., 2004. Vulnerability of Bemisia tabaci immatures to phytoseiid predators: Consequences for oviposition and influence of alternative food. Entomologia Experimentalis et Applicata 110, 95-102.

Nucifora, A., Calabretta, C., 1986. Advances in integrated control of gerbera protected crops. Acta Horticulturae 176, 191-198.

Onillon, J.C., 1999. Biological control of leafminers. In: Albajes, R., Gullino, M.L., van Lenteren, J.C., Elad, Y., (Eds.), Integrated pest and disease management in greenhouse crops. Kluwer Academic Publishers, Netherlands, pp. 254-264. 
Pappas, M.L., Steppuhn, A., Geuss, D., Topalidou, N., Zografou, A., Sabelis, M.W., Broufas, G.D., 2015. Beyond predation: The zoophytophagous predator Macrolophus pygmaeus induces tomato resistance against spider mites. PLoS ONE 10, e0127251.

Pappas, M.L., Steppuhn, A., Broufas, G.D., 2016. The role of phytophagy by predators in shaping plant interactions with their pests. Communicative \& Integrative Biology 9, 1-4.

Paré, P.W., Tumlinson, J.H., 1997. De novo biosynthesis of volatiles induced by insect herbivory in cotton plants. Plant Physiology 114, 1161-1167.

Paré, P.W., Tumlinson, J.H., 1999. Plant volatiles as a defense against insect herbivores. Plant Physiology 121, 325-331.

Park, H.H., Shipp, L., Buitenhuis, R., 2010. Predation, development, and oviposition by the predatory mite Amblyseius swirkii (Acari: Phytoseiidae) on tomato russet mite (Acari: Eriophyidae). Journal of Economic Entomology 103, 563-569.

Perdikis, D.C.H., Lykouressis, D.P., 1996. Aphid population and their enemies on fresh market tomatoes in central Greece. IOBC/WPRS Bulletin 19, 33-37.

Perdikis, D.C.H., Lykouressis, D.P, 1997. Rate of development and mortality of nymphal stages of the predator Macrolophus pygmaeus Rambur feeding on various preys and host plants. IOBC/WPRS Bulletin 20, 241-248.

Perdikis, D.C.H., Lykouressis, D.P., 1999. Development and mortality of the nymphal stages of the predatory bug Macrolophus pygmaeus, when maintained at different temperatures and on different host plants. IOBC/WPRS Bulletin 22, 137-144. 
Perdikis, D.C.H., Lykouressis, D.P., 2000. Effects of various items, host plant and temperature on the development and survival of Macrolophus pygmaeus (Rambur) (Hemiptera: Miridae). Biological Control 17, 55-60.

Perdikis, D.C.H., Lykouressis, D.P., 2002. Life table and biological characteristics of Macrolophuspygmaeus when feeding on Myzus persicae and Trialeurodes vaporariorum. Entomological Experimentalis et Applicata 102, 261-272.

Perdikis, D.C.H., Lykouressis, D.P., 2004. Myzus persicae (Homoptera: Aphididae) as suitable prey for Macrolophus pygmaeus (Hemiptera: Miridae) population increase on pepper plants. Environmental Entomology 33, 499-505.

Perdikis, D.C.H., Fatinou, A., Lykouressis, D.P., 2011. Enhancing pest control in annual crops by conservation of predatory Heteroptera. Biological Control 59, 13-21.

Perdikis, D.C.H., Lucas, E., Garantonakis, N., Giatropoulos, A., Kitsis, P., Maselou, D., Panagakis, S., Lampropoulos, P., Paraskevopoulos, A., Lykouressis, D.P., Fantinou, A., 2014. Intraguild predation and sublethal interactions between two zoophytophagous mirids, Macrolophus pygmaeus and Nesidiocoris tenuis. Biological Control 70, 35-41.

Pérez-Hedo, M., Urbaneja, A., 2015. Prospects for predatory mirid bugs as biocontrol agents of aphids in sweet peppers. Journal of Pest Science 88, 65-73.

Pérez-Hedo, M., Urbaneja-Bernat, P., Jaques, J.A., Flors, V., Urbaneja, A., 2015a.

Defensive plant responses induced by Nesidiocoris tenuis (Hemiptera: Miridae) on tomato plants. Journal of Pest Science 88, 543-554. 
Pérez-Hedo, M., Bouagga, S., Jaques, J.A., Flors, V., Urbaneja, A., $2015 b$. Tomato plant responses to feeding behavior of three zoophytophagous predators (Hemiptera: Miridae). Biological Control 86, 46-51.

Pérez-Hedo, M., Urbaneja, A., 2016. The zoophytophagous predator Nesidiocoris tenuis: A successful but controversial biocontrol agent in tomato crops. In: Horowitz, A.R., Ishaaya, I., (Eds.), Advances in Insect Control and Resistance Management. Springer, Netherlands, Dordrecht, pp.121-138.

Pérez-Hedo, M., Suay, R., Alonso, M., Ruocco, M., Giorgin, M., Poncet, C., Urbaneja, A., 2017a. Resilience and robustness of IPM in protected horticulture in the face of potential invasive pests. Crop Protection 97, 119-127.

Pérez-Hedo, M., Rambla, J.L., Granell, A., Urbaneja, A., 2017b. Biological activity and specificity of Miridae-induced plant volatiles. BioControl. https://doi.org/10.1007/s1052

Peters, D., Wijkamp, I., Van de Wetering, F., Goldbach, R., 1996. Vector relations in the transmission and epidemiology of tospoviruses. Acta Horticulturae 431, 29-43.

Pichersky, E., Gershenzon, J., 2002. The formation and function of plant volatiles: Perfumes for pollinator attraction and defense. Current Opinion in Plant Biology 5, 237-243.

Pichersky, E., Noel, J.P., Dudareva, N., 2006. Biosynthesis of plant volatiles: nature's diversity and ingenuity. Science 311, 808-811.

Pieterse, C.M.J., van der Does, D., Zamioudis, C., Leon-Reyes, A., van Wees, S.C.M., 2012. Hormonal modulation of plant immunity. Annual Review of Cell and Developmental Biology 28, 489-521. 
Pineda, A., Marcos-García, M.A., 2008. Seasonal abundance of aphidophagous hoverflies (Diptera: Syrphidae) and their population levels in and outside Mediterranean sweet pepper greenhouses. Annals of the Entomological Society of America 101, 384-391.

Poelman, E.H., Broekgaarden, C., Van Loon, J.J.A., Dicke, M., 2008. Early season herbivore differentially affects plant defence responses to subsequently colonizing herbivores and their abundance in the field. Molecular Ecology 17, 3352-3365.

Poelman, E.H., Bruinsma, M., Zhu, F., Weldegergis, B.T., Boursault, A.E., Jongema, Y., van Loon, J.J.A., Vet, L.E.M., Harvey, J.A., Dicke, M., 2012. Hyperparasitoids use herbivore-induced plant volatiles to locate their parasitoid host. PLoS Biology 10, e1001435.

Polis, G.A., Myers, C.A., Holt, R.D., 1989. The ecology and evolution of intraguild predation: Potential competitors that eat each other. Annual Review of Ecology and Systematics 20, 297-330.

Ponzio, C., Gols, R., Pieterse, C.M.J., Dicke, M., 2013. Ecological and phytohormonal aspects of plant volatile emission in response to single and dual infestations with herbivores and phytopathogens. Functional Ecology 27, 587-598.

Ponzio, C., Gols, R., Weldegergis, B.T., Dicke, M., 2014. Caterpillar-induced plant volatiles remain a reliable signal for foraging wasps during dual attack with a plant pathogen or non-host insect herbivore. Plant, Cell \& Environment 37, 1924-1935

Portillo, N., Alomar, O., Wäckers, F., 2012. Nectarivory by the plant-tissue feeding predator Macrolophus pygmaeus Rambur (Heteroptera: Miridae): Nutritional redundancy or nutritional benefit? Journal of Insect Physiology 58, 397-401. 
Price, P.W., Bouton, C.E., Gross, P., McPheron, B.A., Thompson, J.N., Weis, A.E., 1980. Interactions among three trophic levels: Influence of plants on interactions between insect herbivores and natural enemies. Annual Review of Ecology, Evolutions and Sytematics 11, 41-65.

Pullin, A.S., Gilbert, J.E., 1989. The stinging nettle, Urtica dioica, increases trichome density after herbivore and mechanical damage. Oikos 54, 275-280.

Rabasse, J.M., van Steenis, M.J., 1999. Biological Control of Aphids. In: Albajes, R., Lodovica Gullino, M., van Lenteren, J.C., Elad, Y., (Eds.), Integrated pest and disease management in greenhouse crops. Springer, Netherlands, Dordrecht, pp. 235-243.

Raman, K., Sanjayan, K., Suresh, G., 1984. Impact of feeding injury of Cyrtopeltis tenuis Reut. (Hemiptera: Miridae) on some biochemical changes in Lycopersicon esculentum Mill. (Solanaceae). Current Science 53, 1092-1093.

Ranganath, H.R., Naveena, N.L., Saroja, S., Yeshwanth, H.M., 2015. Mirid bug, Nesidiocoris cruentatus (Ballard), an emerging pest on bottle gourd, Lagenaria siceraria (Molina) Standley. Pest Management in Horticultural Ecosystems 21, 104-105.

Rasmann, S., Kollner, T.G., Degenhardt, J., Hiltpold, I., Toepfer, S., Kuhlmann, U., Gershenzon, J., Turlings, T.C.J., 2005. Recruitment of entomopathogenic nematodes by insect-damaged maize roots. Nature 434, 732-737.

Rasmann, S., Turlings, T.C.J., 2007. Simultaneous feeding by aboveground and belowground herbivores attenuates plant-mediated attraction of their respective natural enemies. Ecology Letters 10, 926-936. 
Reymond, P., Bodenhausen, N., Van Poecke, R.M.P., Krishnamurthy,

V., Dicke, M., Farmer, E.E., 2004. A conserved transcript pattern in response to a specialist and a generalist herbivore. The Plant Cell 16, 3132-3147.

Rhoades, D.F., 1985. Offensive-defensive interactions between herbivores and plants: Their relevance in herbivore population dynamics and ecological theory. The American Naturalist 125, 205-238.

Rim, H., Uefune, M., Ozawa, R., Takabayashi, J., 2015. Olfactory response of the omnivorous mirid bug Nesidiocoris tenuis to eggplants infested by prey: Specificity in prey developmental stages and prey species. Biological Control 91, 47-54.

Rim, H., Uefune, M.,Ozawa, R., Yoneya, K., Takabayashi, J., 2017. Experience of plant infestation by the omnivorous arthropod Nesidiocoris tenuis affects its subsequent responses to prey-infested plant volatiles. BioControl 62, 233-242.

Riudavets, J., Gabarra, R., Castañé, C.,1993. Frankliniellaoccidentalis predation by native natural enemies. IOBC/WPRS Bulletin 16, 137-140.

Riudavets, J., 1995. Predators of Frankliniella occidentalis (Perg.) and Thrips tabaci Lind.: A review. Wageningen Agricultural University Papers, 43-87.

Riudavets, J., Castañé, C., 1998. Identification and evaluation of native predators of Frankliniella occidentalis (Thysanoptera: Thripidae). Environmental Entomology 27, 86-93.

Roditakis, N.E., Perdikis, D., Roditakis, E., Lykouressis, D.P., Papadaki, M., 2003. Beneficial Hemiptera Anthocoridae and Miridae in Crete., 10th Panhellenic Entomological Congress, Heraklion Crete, pp. 93. 
Rosenheim, J.A., Kaya, H.K., Ehler, L.E., Marois, J.J., Jaffee, B.A., 1995. Intraguild predation among biological-control agents: theory and evidence. Biological Control 5, 303-335.

Rosenheim, J.A., 1998. Higher order predators and the regulation of insect herbivore populations. Annual Review of Entomology, 43, 421-447.

Rosenheim, J.A, Harmon, J., 2006. The influence of intraguild predation on the suppression of a shared prey population: an empirical reassessment. In: Brodeur, J., Boivin, G., (Eds.) Trophic and guild interactions in biological control. Springer, New York, USA, pp. 1-20.

Rubatzky, V.E., Yamaguchi, M., 1997a. Importance of vegetables in human nutrition. World Vegetables: Principles, Production, and Nutritive Values. Springer US, Boston, MA, pp. 34-41.

Rubatzky, V.E., Yamaguchi, M., 1997b. Tomatoes, Peppers, Eggplants, and Other Solanaceous Vegetables. World Vegetables: Principles, Production, and Nutritive Values. Springer US, Boston, MA, pp. 532-576.

Runyon, J.B., Mescher, M.C., De Moraes, C.M., 2006. Volatile chemical cues guide host location and host selection by parasitic plants. Science 313, 1964-1967.

Sabelis, M.W., Janssen, A., Pallini, A., Venzon, M., Bruin, J., Drukker, B., Scutareanu, P., 1999. Behavioural responses of predatory and herbivorous arthropods to induced plant volatiles: from evolutionary ecology to agricultural applications. In: Agrawal, A., Tuzun, S., Bent, E., (Eds.), Induced plant defences against pathogens and herbivores. American Phytopathological Society, St. Paul Minnesota USA, pp. 269-296. 
Sabelis, M.W., Takabayashi, J., Janssen, A., Kant, M.R., van Wijk, M., Sznajder, B.A., Aratchige, N.S., Lesna, I., Belliure, B., Schuurink, R.C., 2007. Ecology meets plant physiology: herbivore-induced plant responses and their indirect effects on arthropod communities. In: Ohgushi, T., Craig, T., P, Price, P., W, Eds.), Ecological communities: plant mediation in indirect interaction webs. Cambridge University Press, Cambridge, UK, pp. 188-217.

Sampson, C., Jacobson, R.J., 1999. Macrolophus caliginosus Wagner (Heteroptera: Miridae): A predator causing damage to UK tomatoes. IOBC/WPRS Bulletin 22, 213-216.

Sanchez, C., Gallego, J.R., Manuel, G., Cabello, T., 2014. Intensive biological control in Spanish greenhouses: problems of the success. International Scholarly and Scientific Research \& Innovation 8, 1123-1127.

Sánchez, J.A., Alcazar, A., Lacasa, A., Llamas, A., Bielza, P., 2000. Integrated pest management strategies in sweet pepper plastic houses in the southeast of Spain. IOBC/WPRS Bulletin 23, 21-30.

Sánchez, J.A., Lacasa, A., 2002. Modelling population dynamics of Orius laevigatus and O. albidipennis (Hemiptera: Anthocoridae) to optimize their use as biological control agents of Frankliniellaoccidentalis (Thysanoptera: Thripidae). Bulletin of Entomological Research 92, 77-88.

Sánchez, J.A., Martinez-cascales, J.I., Lacasa, A., 2003. Abundance and wild host plants of predator mirids (Heteroptera: Miridae) in horticultural crops in the southeast of Spain. IOBC/WPRS Bulletin 26, 147-151.

Sánchez, J.A., Gillespie, D.R., McGregor, R.R., 2004. Plant preference in relation to life history traits in the zoophytophagous predator Dicyphus hesperus. Entomologia Experimentalis et Applicata 112, 7-19. 
Sánchez, J.A., 2008. Zoophytophagy in the plant bug Nesidiocoris tenuis. Agricultural and Forest Entomology 10, 75-80.

Sánchez, J.A., Lacasa, A., 2008. Impact of the zoophytophagous plant bug Nesidiocoris tenuis (Heteroptera: Miridae) on tomato yield. Journal of Economic Entomology 101, 1864-1870.

Sánchez, J.A., 2009. Density thresholds for Nesidiocoris tenuis (Heteroptera: Miridae) in tomato crops. Biological Control 51, 493-498.

Sánchez, J.A., Lacasa, A., Arnó, J., Castañé, C., Alómar, O., 2009. Life history parameters for Nesidiocoris tenuis (Reuter) (Het, Miridae) under different temperature regimes. Journal of Applied Entomology 133, 125-132.

Sánchez, J.A., La-Spina, M., Michelena, J.M., Lacasa, A., De Mendoza, A.H., 2011. Ecology of the aphid pests of protected pepper crops and their parasitoids. Biocontrol Science and Technology 21, 171-188.

Sánchez, J.A., La-Spina, M., Lacasa, A., 2014. Numerical response of Nesidiocoris tenuis (Hemiptera: Miridae) preying on Tuta absoluta (Lepidoptera: Gelechiidae) in tomato crops. European Journal of Entomology 111, 387-395.

Sánchez, J.A., del Amor, F.M., Flores, P., López-Gallego, E., 2016. Nutritional variations at Nesidiocoris tenuis feeding sites and reciprocal interactions between the mirid and tomato plants. Journal of Applied Entomology 140, 161-173.

Santamaria, M.E., Martínez, M., Cambra, I., Grbic, V., Diaz, I., 2013. Understanding plant defence responses against herbivore attacks: an essential first step towards the development of sustainable resistance against pests. Transgenic Research 22, 697-708. 
Schaefer, C.W., Panizzi, A.R., 2000. Heteroptera of economic importance. CRC, FL Press, Boca Raton.

Schmidt, R., 2014. Leaf structures affect predatory mites (Acari: Phytoseiidae) and biological control: a review. Experimental and Applied Acarology 62, 1-17.

Sendoya, S.F., Freitas, A.V.L., Oliveira, P.S., 2009. Egg-laying butterflies distinguish predaceous ants by sight. The American Naturalist 174, 134-140.

Settle, W.H., Ariawan, H., Astuti, E.T., Cahyana, W., Hakim, A.L., Hindayana, D., Lestari, A.S., 1996. Managing tropical rice pests through conservation of generalist natural enemies and alternative prey. Ecology 77, 1975-1988.

Shakya, S., Weintraub, P.G., Coll, M., 2009. Effect of pollen supplement on intraguild predatory interactions between two omnivores: the importance of spatial dynamics. Biologicol control 50, 281-287.

Sharma, H.C., Sujana, G., Manohar Rao, D., 2009. Morphological and chemical components of resistance to pod borer, Helicoverpa armigera in wild relatives of pigeonpea. Arthropod-Plant Interactions 3, 151-161.

Shi, X., Chen, G., Tian, L., Peng, Z., Xie, W., Wu, Q., Wang, S., Zhou, X., Zhang, Y., 2016. The salicylic acid-mediated release of plant volatiles affects the host choice of Bemisia tabaci. International Journal of Molecular Sciences 17, 1048.

Shipp, J.L., Hao, X., Papadopoulos, A.P., Binns, M.R., 1998. Impact of western flower thrips (Thysanoptera: Thripidae) on growth, photosynthesis and productivity of greenhouse sweet pepper. Scientia Horticulturae 102, 72-87. 
Shivaji, R., Camas, A., Ankala, A., Engelberth, J., Tumlinson, J.H., Williams, W.P., Wilkinson, J.R., Luthe, D.S., 2010. Plants on constant alert: elevated levels of jasmonic acid and jasmonate-induced transcripts in caterpillar-resistant maize. Journal of Chemical Ecology 36, 179-191.

Silva, D.B., Weldegergis, B.T., van Loon, J.J.A., Bueno, V.H.P., 2017. Qualitative and quantitative differences in herbivore-induced plant volatile blends from tomato plants infested by either Tuta absoluta or Bemisia tabaci. Journal of Chemical Ecology 43, 53-65.

Simón, A., García, C., Pascual, F., Ruiz, L., Janssen, D., 2016. The influence of crop habitat and control strategies on pepper viruses in Andalusia (Spain). Horticulturae 2, 15.

Smart, L.E., Martin, J.L., Limpalaër, M., Bruce, T.J.A., Pickett, J.A., 2013. Responses of herbivore and predatory mites to tomato plants exposed to jasmonic acid seed treatment. Journal of Chemical Ecology 39, 1297-1300.

Soler, R., Van der Putten, W.H., Harvey, J.A., Vet, L.E.M., Dicke, M., Bezemer, T.M., 2012. Root herbivore effects on aboveground multitrophic interactions: patterns, processes and mechanisms. Journal of Chemical Ecology 38, 755-767.

Stansly, P.A., Sánchez, P.A., Rodriguez, J.M., Canizares, F., Nieto, A., Lopez, M.J., Fajardo, M., Suarez, V., Urbaneja, A., 2004. Prospects for biological control of Bemisia tabaci (Homoptera: Aleyrodidae) in greenhouse tomatoes of Southern Spain. Crop Protection 23, 710-712.

Stansly, P.A., Calvo, J., Urbaneja, A., 2005. Augmentative biological control of Bemisia tabaci biotype " $\mathrm{Q}$ " in greenhouse pepper using Eretmocerus spp. (Hym. Aphelinidae). Crop Protection 24, 829-835. 
Sylla, S., Brévault, T., Diarra, K., Bearez, P., Desneux, N., 2016. Life-history traits of Macrolophus pygmaeus with different prey foods. PLoS ONE 11, e0166610.

Takabayashi, J., Dicke, M., 1996. Plant-carnivore mutualism through herbivore-induced carnivore attractants. Trends in Plant Science 1, 109-113.

Tavella, L., Arzone, A., Alma, A., 1991. Researches on Orius laevigatus (Fieb.), a predator of Frankliniella occidentalis (Perg.) in greenhouse. A prelimenary note. IOBC/WPRS Bulletin 14, 65-71.

Tavella, L., Alma, A., Conti, A., Arzone, A., 1996. Evaluation of the effectiveness of Orius spp. in controlling Frankliniella occidentalis. Acta Horticultura 431, 499-506.

Tavella, L., Arzone, A., 1996. Development of Macrolophus caliginosus and Dicyphus errans on different diets (Rynchota: Miridae). Proceedings of the XX International Congress of Entomology, Florence, Italy, pp. 652.

Tavella, L., Alma, A., Sargiotto, C., 1997. Sampling of Miridae Dicyphinae in tomato crops of northwestern Italy. IOBC/WPRS Bulletin 20, 249-256.

Tavella, L., Goula, M., 2001. Dicyphini collected in horticultural areas of north-western Italy (Heteroptera Miridae). Bollettino di Zoologia Agraria e di Bachicoltura 33, 93-102.

Tommasini, M.G., Maini, S., 1995. Frankliniella occidentalis and other thrips harmful to vegetable and ornamental crops in Europe. Wageningen Agricultural University Papers 95, 1-42.

Tommasini, M.G., Nicoli, G., 1996. Evaluation of Orius spp. as biological control agents of thrips pests. Further experiments on the existence of diapause in Orius laevigatus. OILB/SORP Bulletin 19, 183-186. 
Torreno, H.S., Magallona, E.D., 1994. Biological relationship of the bug, Cyrtopeltis tenuis Reuter (Hemiptera: Miridae) with tobacco. Philippine Entomologist 9, 406-425.

Trottin-Caudal, Y., Baffert, V., Leyre, J.M., Hulas, N., 2012. Experimental studies on Tuta absoluta (Meyrick) in protected tomato crops in France: Biological control and integrated crop protection. EPPO Bulletin 42, 234-240.

Turlings, T.C.J., Tumlinson, J.H., Lewis, W.J., 1990. Exploitation of herbivore-induced plant odors by host-seeking parasitic wasps. Science 250, 1251-1253.

Turlings, T.C.J., Lengwiler, U.B., Bernasconi, M.L., Wechsler, D., 1998. Timing of induced volatile emissions in maize seedlings. Planta 207, 146-152.

Ullman, D.E., Shirwood, J.L., German, T.L., 1997. Thrips as vectors of plant pathogens. In: Lewis, T., (Ed.), Thrips as crop pests. CAB, International, Wallingford, UK, pp. 539-565.

Urbaneja, A., Aran, E., Squires, P., Lara, L., van der Blom, J., 2001. Aparición del chinche Creontiades pallidus Ramb. (Hemiptera: Miridae) como depredador de mosca blanca y posible causante de daños en los cultivos de pimiento en invernadero. Primeros datos sobre su biología en laboratorio. Agrícola Vergel 235, 396-401.

Urbaneja, A., Arán, E., León, P., Gallego, A., 2002. Efecto combinado de altas temperaturas y de humedades relativas en la supervivencia, fecundidad y fertilidad de Orius laevigatus y Orius albidipennis (Hem.: Anthocoridae). Boletín de sanidad vegetal. Plagas 29, 27-35. 
Urbaneja, A., Leon, F.J., Gimenez, A., Aran, E., van der Blom, J., 2003. The interaction of Neoseiulus (Amblyseius) cucumeris (Oudemans) (Aca.: Phytoseiidae) on the installation of Orius laevigatus (Fieber) (Hem.: Anthocoridae) in sweet pepper crops. Boletín de Sanidad Vegetal Plagas 29, 1-12.

Urbaneja, A., Stansly, P.A., 2004. Host suitability of different instars of the whitefly Bemisia tabaci 'biotype Q' for Eretmocerus mundus. BioControl 49, 153-161.

Urbaneja, A., Tapia, G., Stansly, P.A., 2005. Influence of host plant and prey availability on developmental time and survival of Nesidiocoris tenuis Reuter (Het: Miridae). Biocontrol Science and Technology 15, 513-518. Urbaneja, A., González-Cabrera, J., Arnó, J., Gabarra, R., 2012. Prospects for the biological control of Tuta absoluta in tomatoes of the Mediterranean basin. Pest Management Science 68, 1215-1222.

Urbaneja-Bernat, P., Mollá, O., Alonso, M., Bolckmans, K., Urbaneja, A., Tena, A., 2015. Sugars as complementary alternative food for the establishment of Nesidiocoris tenuis in greenhouse tomato. Journal of Applied Entomolology 139, 161-167.

Vacante, V., Cocuzza, G.E., De Clercq, P., Van de Veire, M., Tirry, L., 1997. Development and survival of Orius albidipennis and O. laevigatus (Het.: Anthocoridae) on various diets. Entomophaga 42, 493.

Vaello, T., Casas, J.L., Pineda, A., de Alfonso, I., Marcos-García, M.Á., 2017. Olfactory response of the predatory bug Orius laevigatus (Hemiptera: Anthocoridae) to the aggregation pheromone of its prey, Frankliniella occidentalis (Thysanoptera: Thripidae). Environmental Entomology 46, 1115-1119. 
Valderrama, K., Granobles, J., Valencia, E., Sanchez, M., 2007. Nesidiocoris tenuis (Hemiptera: Miridae) predator in tobacco crops (Nicotiana tabacum). Revista Colombiana De Entomología 33, 141-145. van de Vrie, M., Murtry, J.A., Huffaker, C.B., 1972. Ecology of mites and their natural enemies. A review. III Biology, ecology, and pest status, and host plant relations of Tetranychids. Hilgardia 41, 354-432.

van Driesche, R.G., Heinz, K.M., van Lenteren, J.C., Loomans, A., Wick, R., Smith, T., Lopes, P., Sanderson, J.P., Daughtrey, M., and Brownbridge, M., 1998. Western flower thrips in greenhouses: A review of its biological control and other methods. Floral Facts, University of Massachusetts, Amherst, MA. pp. 1-31.

van Houten, Y.M., Ostlie, M.L., Hoogerbrugge, H., Bolckmans, K.J.F, 2005. Biological control of western flower thrips on sweet pepper using the predatory mites Amblyseius cucumeris, Iphiseius degenerans, A. andersoni and A. swirskii. IOBC/WPRS Bulletin 28, 283-286.

van Lenteren, J.C., Woets, J., 1988. Biological and integrated pest control in greenhouses. Annual Review of Entomology 33, 239-269.

van Lenteren, J.C., Loomans, A.J.M., 1998. Is there a natural enemy good enough for biological control of thrips?, Brighton crop protection conference: pests and diseases British crop protection concil, Farnham, pp. 401-408.

van Lenteren, J.C., 2003. Quality control and production of biological control agents: theory and testing procedures. CABI Publishing, Wallingford, UK.

van Lenteren, J.C., Bueno, V.H.P., 2003. Augmentative biological control of arthropods in Latin America. BioControl 48, 123-139. 
van Lenteren, J.C., 2007. Biological control for insect pests in greenhouses: an unexpected success. In: Vicent, C., Goettel, M.S., Lazarovits, G., (Eds.), Biological control: a global perspective CAB Int. Wallingford, UK, pp. 105-117.

van Lenteren, J.C., 2012. The state of commercial augmentative biological control: plenty of natural enemies but a frustrating lack of uptake. BioControl 57, 1-20.

van Lenteren, J.C., Bolckmans, K, Kohl, J., Ravensberg, W.J., Urbaneja, A., 2018. Biological control using invertebrates and microorganisms: plenty of new opportunities. BioControl 63, 39-59.

van Maanen, R., Vila, E., Sabelis, M.W., Janssen, A., 2010. Biological control of broad mites (Polyphagotarsonemus latus) with the generalist predator Amblyseius swirskii. Experimental and Applied Acarology 52, 29-34.

van Schelt, J., 1999. Biological control of sweet pepper pests in the Netherlands. IOBC/WPRS Bulletin 22, 217-220.

Venzon, M., Janssen, A., Sabelis, M.W., 2002. Prey preference and reproductive success of the generalist predator Orius laevigatus. Oikos 97, 116-124.

Verkerk, R.H.J., 2004. Manipulation of tritrophic interactions for IPM. In: Koul, O., Dhaliwal, G.S., Cuperus, G.W., (Eds.), Intregrated pest management: potential, constraints and challenges. CABI, ISBN 0851996868, Oxfordshire, UK, pp. 55-71.

Vet, L.E.M., Wackers, F.L., Dicke, M., 1991. How to hunt for hiding hosts: the reliability-detectability problem for foraging parasitoids. Netherlands Journal of Zoology 41, 202-213.

Vet, L.E.M. 2001. Parasitoid searching efficiency links behaviour to population processes. Applied Entomology \& Zoology 36, 399-408. 
Vinatier, F., Tixier, P., Duyck, P.-F., Lescourret, F., 2011. Factors and mechanisms explaining spatial heterogeneity: a review of methods for insect populations. Methods in Ecology and Evolution 2, 11-22.

Voelckel, C., Baldwin, I.T., 2004. Herbivore-induced plant vaccination. Part II. Array-studies reveal the transience of herbivore-specific transcriptional imprints and a distinct imprint from stress combinations. The Plant Journal 38, 650-663.

Voigt, D., Gorb, E., Gorb, S., 2007. Plant surface-bug interactions: Dicyphuserrans stalking along trichomes. Arthropod-Plant Interactions 1, 221-243.

Voigt, D., Gorb, S., 2010. Locomotion in a sticky terrain. Arthropod-Plant Interactions 4, 69-79.

von Dahl, C.C., Baldwin, I.T., 2007. Deciphering the role of ethylene in plant-herbivore interactions. Journal of Plant Growth Regulation 26, 201-209.

Wagner, E., Weber, H.H., 1964. Hétéroptères Miridae. Faune de France 67. Fédération Française des Sociétés de Sciences Naturelles, Paris.

Walker, G.P., 2003. Salivary glands. In: Resh, V.H., Cardé, R.T., (Eds.), Encyclopedia of Insects. Academic Press, Amsterdam; Boston.

Walling, L.L., 2000. The myriad plant responses to herbivores. Journal of Plant Growth Regulation 19, 195-216.

Walling, L.L., 2008. Avoiding effective defenses: strategies employed by phloem-feeding insects. Plant Physiology 146, 859-866.

Walter, D.E., 1996. Living on leaves: mites, tomenta, and leaf domatia. Annual Review Entomology 41, 101-114. 
War, A.R., Sharma, H.C., Paulraj, M.G., War, M.Y., Ignacimuthu, S., 2011. Herbivore induced plant volatiles: Their role in plant defense for pest management. Plant Signaling \& Behavior 6, 1973-1978.

War, A.R., Paulraj, M.G., Ahmad, T., Buhroo, A.A., Hussain, B., Ignacimuthu, S., Sharma, H.C., 2012. Mechanisms of plant defense against insect herbivores. Plant Signaling \& Behavior 7, 1306-1320.

Wasserberg, G., White, L., Bullard, A., King, J., Maxwell, R., 2013. Oviposition site selection in Aedes albopictus (Diptera: Culicidae): Are the effects of predation risk and food level independent? Journal of Medical Entomology 50, 1159-1164.

Weintraub, P.G., 2007. Integrated control of pests in tropical and subtropical sweet pepper production. Pest Management Science 63, 753-760.

Weintraub, P.G., Pivonia, S., Steinberg, S., 2011. How many Orius laevigatus are needed for effective western flower thrips, Frankliniella occidentalis, management in sweet pepper? Crop Protection 30, 1443-1448.

Werner, E.E., Peacor, S.D., 2003. A review of trait-mediated indirect interactions in ecological communities. Ecology 84, 1083-1100.

Wetering, F., Hulshof, J., Posthuma, K., Harrewijn, P., Goldbach, R., Peters, D., 1998. Distinct feeding behavior between sexes of Frankliniella occidentalis results in higher scar production and lower tospovirus transmission by females. Entomologia Experimentalis et Applicata 88, 9-15.

Wheeler, A.G., 2001. Biology of the plant bugs (Hemiptera: Miridae): pests, predators, opportunists. Cornell University Press, Ithaca.

Wu, J., Hettenhausen, C., Meldau, S., Baldwin, I.T., 2007. Herbivory rapidly activates MAPK signaling in attacked and unattacked leaf regions but not between leaves of Nicotiana attenuata. The Plant Cell 19, 1096. 
Yano, E., Jiang, N., Hemerik, L., Mochizuki, M., Mitsunaga, T., Shimoda, T., 2005. Time allocation of Orius sauteri in attacking Thrips palmi on an eggplant leaf. Entomologia Experimentalis et Applicata 117, 177-184.

Yi, H.S., Heil, M., Adame-Álvarez, R.M., Ballhorn, D.J., Ryu, C.M., 2009. Airborne induction and priming of plant defenses against a bacterial pathogen. Plant Physiology 151, 2152-2161.

Zappalà, L., Siscaro, G., Biondi, A., Molla, O., Gonzalez-Cabrera, J., Urbaneja, A., 2012. Efficacy of sulphur on Tuta absoluta and its side effects on the predator Nesidiocoris tenuis. Journal of Applied Entomology 136, 401-409.

Zappalà, L., Biondi, A., Alma, A., Al-Jboory, I.J., Arnò, J., Bayram, A., Chailleux, A., El-Arnaouty, A., Gerling, D., Guenaoui, Y., ShaltielHarpaz, L., Siscaro, G., Stavrinides, M., Tavella, L., Vercher Aznar, R., Urbaneja, A., Desneux, N., 2013. Natural enemies of the South American moth, Tuta absoluta, in Europe, North Africa and Middle East, and their potential use in pest control strategies. Journal of Pest Science 86, 635-647.

Zeng, F., Cohen, A.C., 2000. Demonstration of amylase from the zoophytophagous anthocorid Orius insidiosus. Archives of insect biochemistry and physiology 44, 136-139.

Zhang, X., Yuan, Y.R., Pei, Y., Lin, S.S., Tuschl, T., Patel, D.J., Chua, N.H., 2006. Cucumber mosaic virus-encoded $2 \mathrm{~b}$ suppressor inhibits Arabidopsis Argonaute1 cleavage activity to counter plant defense. Genes \& Development 20, 3255-3268.

Zhang, Q.H., Aldrich, J.R., 2008. Sex pheromone of the plant bug, Phytocoris calli Knight. Journal of Chemical Ecology 34, 719-724. 
Zhang, P.J., Zheng, S.J., van Loon, J.J.A., Boland, W., David, A., Mumm, R., Dicke, M., 2009. Whiteflies interfere with indirect plant defense against spider mites in Lima bean. Proceedings of the National Academy of Sciences 106, 21202-21207.

Zhang, C., Xie, Q., Anderson, R.G., Ng, G., Seitz, N.C., Peterson, T., McClung, C.P., McDowell, J.M., Kong, D., Kwak, J.M., Lu, H., 2013. Crosstalk between the circadian clock and innate immunity in Arabidopsis. PLoS Pathogens 9, e1003370.

Zhang, N.X., Messelink, G.J., Alba, J.M., Schuurink, R.C., Kant, M.R., Janssen, A., 2018. Phytophagy of omnivorous predator affects performance of herbivores through induced plant defences. Oecologia 186, 101-113.

Zhurov, V., Navarro, M., Bruinsma, K.A., Arbona, V., Santamaria, M.E., Cazaux, M., Wybouw, N., Osborne, E.J., Ens, C., Rioja, C., Vermeirssen, V., Rubio-Somoza, I., Krishna, P., Diaz, I., Schmid, M., Gómez-Cadenas, A., Van de Peer, Y., Grbić, M., Clark, R.M., Van Leeuwen, T., Grbić, V., 2014. Reciprocal responses in the interaction between Arabidopsis and the cell-content-feeding chelicerate herbivore spider mite. Plant Physiology 164, 384-399. 



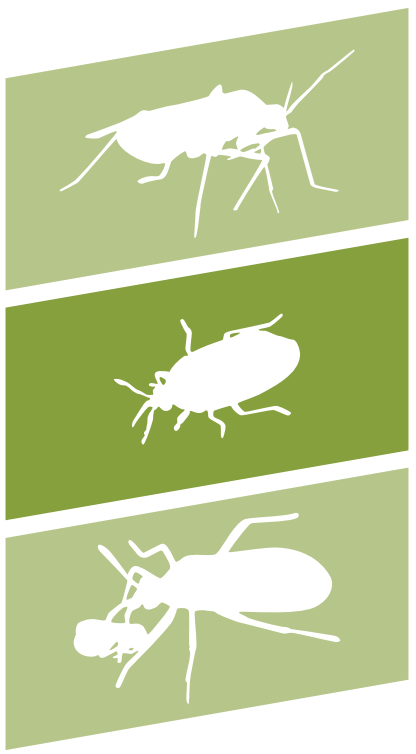

